DISSERTAÇÃO DE MESTRADO

INSTITUTO DE ARQUITETURA E URBANISMO DE SÃO CARLOS

UNIVERSIDADE DE SÃO PAULO

A produção habitacional sob a lógica do mercado imobiliário:análise do Programa Minha Casa Minha Vida na Região Metropolitana de Fortaleza

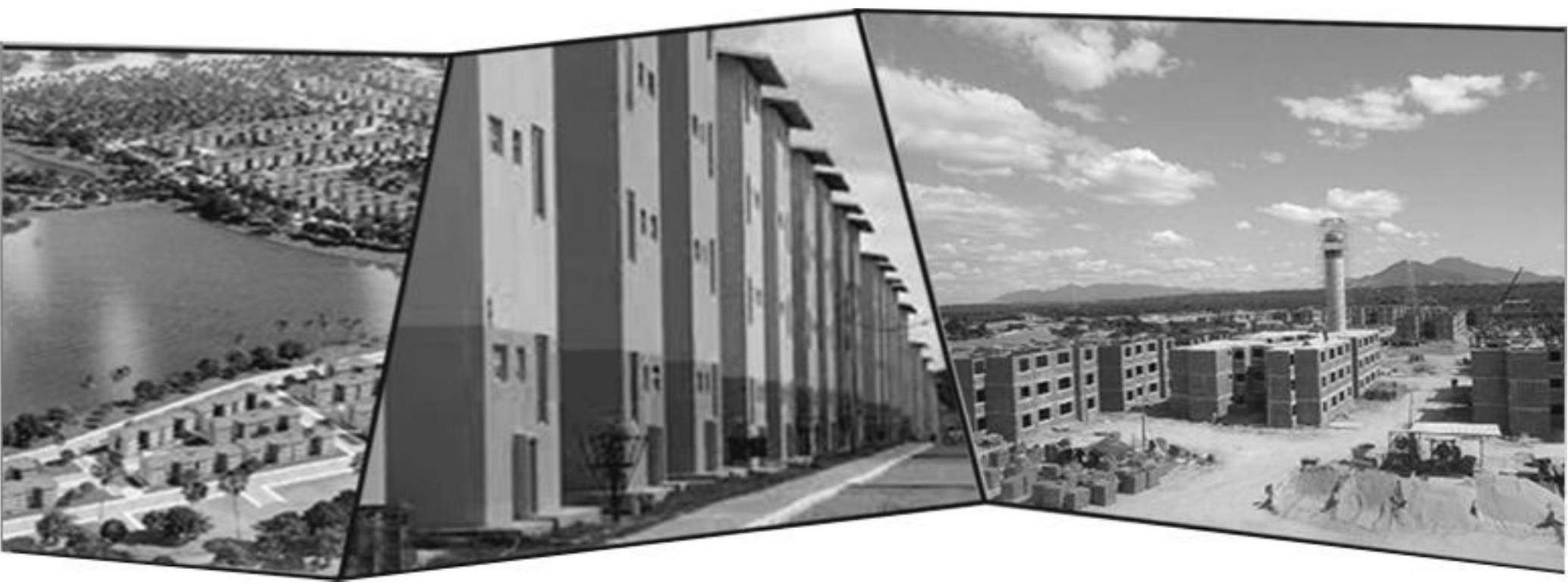

Autora: Clarissa Salomoni de Menezes

Orientador: Dr. Miguel Antonio Buzzar

São Carlos - SP

2016 


\section{A produção habitacional sob a lógica do mercado imobiliário: análise do Programa Minha Casa Minha Vida \\ na Região Metropolitana de Fortaleza}

Versão corrigida

Dissertação submetida(a) ao Programa de Mestrado do Instituto de Arquitetura e Urbanismo da Universidade de São Paulo para obtenção de título de Mestra em Arquitetura e Urbanismo.

Orientador: Prof.Dr. Miguel Antonio Buzzar

São Carlos - SP

2016 
AUTORIZO A REPRODUÇÃO TOTAL OU PARCIAL DESTE TRABALHO, POR QUALQUER MEIO CONVENCIONAL OU ELETRÔNICO, PARA FINS DE ESTUDO E PESQUISA, DESDE QUE CITADA A FONTE.

Ficha catalográfica elaborada pela Biblioteca do Instituto de Arquitetura e Urbanismo com os dados fornecidos pelo(a) autor(a)

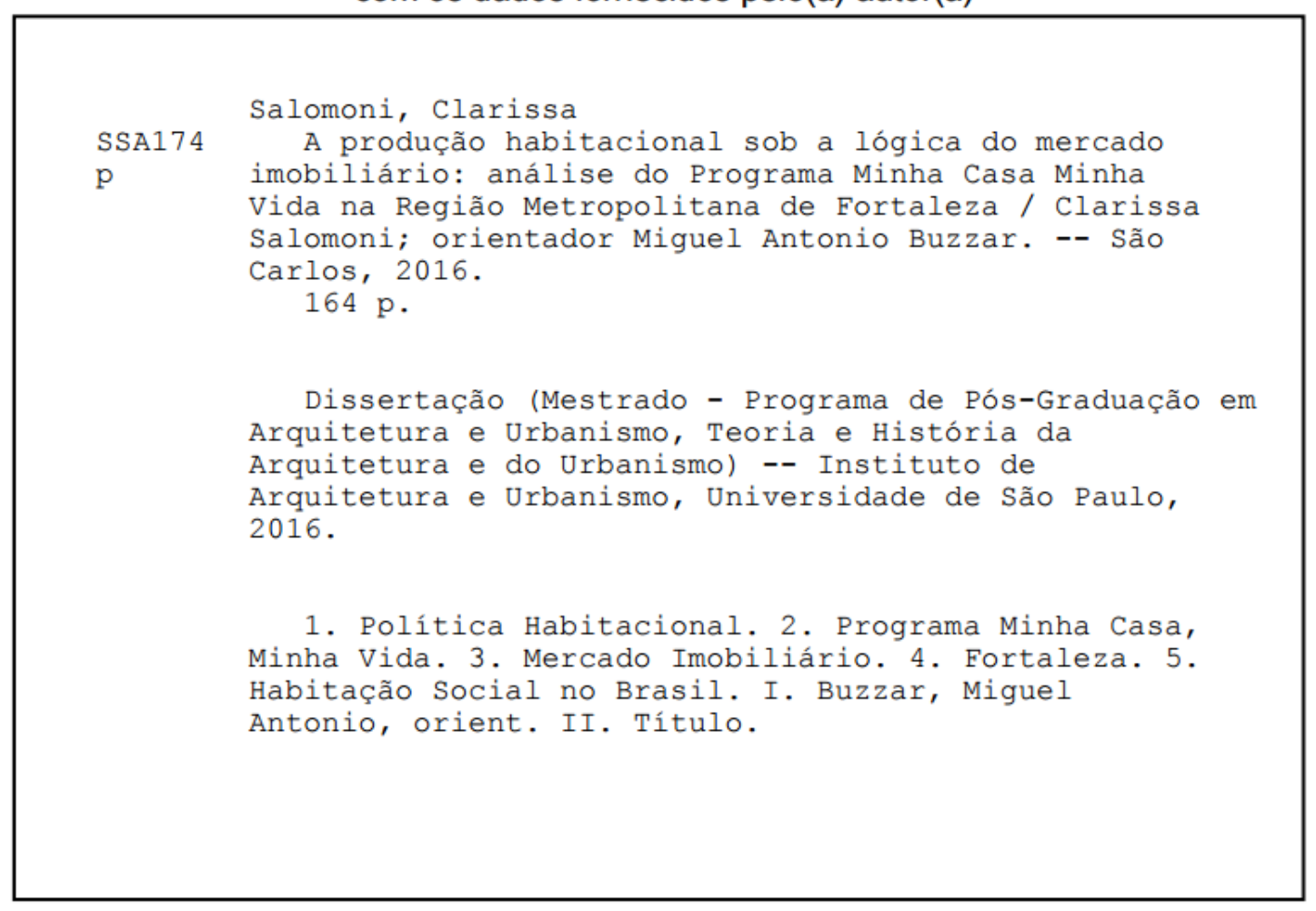




\section{FOLHA DE IULGAMENTO}

Candidato(a): Arquiteta e Urbanista Clarissa Salomoni de Menezes

Título da dissertação: "A produção habitacional sob a lógica do mercado imobiliário: análise do Programa Minha Casa Minha Vida na Região Metropolitana de Fortaleza"

Data da defesa: 22/06/2016

\section{Comissão Julgadora:}

Prof. Dr. Miguel Antonio Buzzar

(Instituto de Arquitetura e Urbanismo/USP)

Profa. Dra. Lucia Zanin Shimbo

(Instituto de Arquitetura e Urbanismo/USP)

Profa. Dra. Maria Beatriz Cruz Rufino

(Faculdade de Arquitetura e Urbanismo/USP)
Resultado:

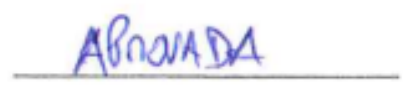

APROVADA

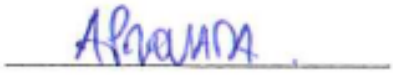

Diretor do Instituto de Arquitetura e Urbanismo - USP: Prof. Dr. Miguel Antonio Buzzar. 
Ao meu Pai, que, com sua força silenciosa, me diz para estar sempre firme ante às dificuldades. 


\section{Agradecimentos}

Ao professor Miguel Buzzar, orientador deste trabalho, pela compreensão incondicional, pela atenção, paciência, sugestões e contribuições para esta pesquisa. Por me orientar em momentos de dificuldades, meus sinceros agradecimentos;

À Comissão de Pós-Graduação do IAU-USP, por me apoiar em todos os momentos decisivos;

Às professoras Beatriz Rufino e Lúcia Shimbo, que muito contribuíram com os rumos deste trabalho, seja com suas pesquisas diante o PMCMV, seja com as indicações e esclarecimentos na banca de qualificação;

Ao Grupo de pesquisa do LEHAB/UFC, pelas discussões, abertura, trocas preciosas e debates que foram fundamentais para a compreensão da realidade em Fortaleza, em especial, ao Professor Renato Pequeno, que ofereceu orientação em momentos de dúvidas e nutriu essa dissertação com importantes informações e dados, afirmo minha admiração pela pesquisa comprometida que o Laboratório realiza em Fortaleza;

Às empresas pesquisadas, sindicatos e agentes da CEF que se disponibilizaram a dar depoimentos e dados importantes para a realização desta pesquisa;

Aos amigos, que dividiram tantas conversas, me apoiaram em momentos em que precisei e que de tanta forma estiveram presentes mesmo na distância;

Ao meu pai, disciplinado e incansável como nunca, fonte de inspiração no seu enfrentamento das dificuldades;

À minha mãe, companheira de todos os momentos, que foi força para alma, alimento para o corpo, esteve comigo e foi fortaleza me dando suporte para realizar essa pesquisa;

Ao companheiro Gabriel, que confiou em mim e esteve ao meu lado;

A todos que me apoiaram e acreditam em mim e nesta pesquisa, meu muito obrigada. 


\section{Resumo}

SALOMONI, Clarissa Menezes. A produção habitacional sob a lógica do mercado imobiliário: análise do Programa Minha Casa Minha Vida na Região Metropolitana de Fortaleza. Dissertação ( Mestrado em Arquitetura e Urbanismo) - Instituto de Arquitetura e Urbanismo da Universidade de São Paulo, São Carlos, 2016.

Esta investigação se propôs a refletir sobre o Programa Minha Casa, Minha Vida (PMCMV) e suas dinâmicas de produção no contexto da Região Metropolitana de Fortaleza (RMF). O caminho percorrido por esta análise privilegiou aspectos políticos que fomentaram o Programa e seu aparato institucional. Notou-se que a retomada de investimentos e recursos para o financiamento habitacional ensejou ampla reconfiguração das empresas construtoras e incorporadoras no âmbito nacional, resultando na expansão imobiliária que rompeu fronteiras urbanas para além dos municípios e mercados antes não explorados. Essa dinâmica interferiu na realidade de Fortaleza e sua região metropolitana, exprimindo características particulares em seu Território e nas suas formas de produção. O recorte do objeto empírico se deu em Fortaleza, Caucaia e Maracanaú, municípios que mais concentraram empreendimentos do PMCMV. Procurou-se dar relevância a estrutura de provisão da habitação, onde o agente privado se mostra como elemento chave do desdobramento desta análise, uma vez que no desenho institucional do Programa as empresas podem assumir todas as etapas da promoção imobiliária, desde a escolha e aquisição do terreno, elaboração do projeto, decisões sob o canteiro, até sua comercialização. Uma vez que a centralidade da decisão da produção habitacional recai nos mecanismos de regulação do mercado, problematiza-se as escolhas do estoque de terrenos para a habitação popular na RMF realizadas desde o lançamento do Programa, em 2009, até 2015 junto a modalidade PMCMV-Empresas. Este trabalho espera contribuir no sentido de alertar dos riscos do retorno das lógicas financeiras do mercado como principal mecanismo de coordenação coletiva do solo urbano.

Palavras-chave: Política Habitacional, Programa Minha Casa, Minha Vida, Mercado Imobiliário, Fortaleza (RMF), Habitação Social no Brasil 


\section{Abstract}

SALOMONI, Clarissa Menezes. Housing production under the logic of the real estate market: analysis of Programa Minha Casa Minha Vida in the Metropolitan Region of Fortaleza. Dissertação (Mestrado em Arquitetura e Urbanismo) - Instituto de Arquitetura e Urbanismo da Universidade de São Paulo, São Carlos, 2016.

This investigation proposed at reflecting on the "Programa Minha Casa, Minha Vida (PMCMV)" and its production dynamics on the context of the metropolitan area of Fortaleza. The path taken by this analysis privileged political aspects that fomented the Program and its institutional apparatus. It was verified that the resumption of investments and resources for housing finance operations gave rise to wide reconfiguration of the construction companies and developers, resulting on a real-estate expansion that went through urban boundaries, beyond city limits and unexplored Market territories. This dynamics interfered on the scenario of Fortaleza and its metropolitan area, expressing particular characteristics on its territory and on its ways of production. The cut-off of this empiric object takes its place on Fortaleza, Caucaia and Maracanau, cities that concentrated PMCMV's real-estate projects on the state of Ceará - Brazil. It was aimed to highlight the structure of housing provisioning, where the private agent shows itself as a key-element on this analysis' unfolding, since the Program's institucional framework allows companies to assume each and all of the stages of the real estate development, like the land selection and acquisition, project elaboration, decisions on the building site, and also its commercialization. Once the centrality of decisions on the housing production falls on the Market regulation mechanisms, the choices on the stocks of land for social housing on Fortaleza's metropolitan area, since the launch of the Program, 2009, until 2015, when of PMCMV - Empresas, are problematized. This thesis hopes to contribute on alerting about the risks of the recurrence of Market finance logics as the main mechanism of colective coordination of the urban land.

Keywords: Housing Policy, Programa Minha Casa, Minha Vida, Real-estate Market, Fortaleza, Social Housing in Brazil 


\section{Listas}

\section{Lista das Siglas}

BB - Banco do Brasil

BC - Banco Central

BNDES - Banco Nacional de Desenvolvimento Econômico e Social

BNH - Banco Nacional de Habitação

BOVESPA - Bolsa de Valores do Estado de São Paulo

CEF - Caixa Econômica Federal

CAGECE - Companhia de Água e Esgoto do Ceará

$\mathrm{CCl}$ - Cédula de Crédito Imobiliário

CIC - Centro Industrial do Ceará

CRI - Certificados de Recebíveis Imobiliários

CMN - Conselho Monetário Nacional

CMP - Central de Movimentos Populares

CNPJ - Cadastro Nacional da Pessoa Jurídica

COEMA - Conselho Estadual do Meio Ambiente

COHAB - Companhia de Habitação

CRECI-CE - Conselho Regional de Corretores de Imóveis do Ceará

CUT - Central Única dos Trabalhadores

COOPERCON - Cooperativa da Construção Civil do Ceará

CUB - Custo Unitário Básico

EO - Entidade Organizadora

FAR - Fundo de Arrendamento Residencial

FAT - Fundo de Amparo ao Trabalhador

FDS - Fundo de Desenvolvimento Social

FHC - Fernando Henrique Cardoso

FGHab - Fundo Garantidor da Habitação Popular

FGTS - Fundo de Garantia do Tempo de Serviço

FNH - Fundo Nacional de Habitação

FNHIS - Fundo Nacional de Habitação de Interesse Social

FNRU - Fórum Nacional da Reforma Urbana

FSSF - Fundação de Serviço Social de Fortaleza

GIDUR - Gerência de Desenvolvimento Urbano

GIGOV - Gerência Executiva de Governo 
GIHAB - Gerência Executiva de Habitação

HABITAFOR - Fundação de Habitação Popular de Fortaleza

IPEA - Instituto de Pesquisa Econômica Aplicada

Instituto de Pesquisa e Estatística Secovi - CE (Inspece)

IFOFs - Instituições Financeiras Oficiais Federais

INOCOOP-CPM - Instituto de Orientação das Cooperativas Habitacionais do Ceará, Piauí e Maranhão

LABHAB- Laboratório de Habitação e Assentamentos Humanos

$\mathrm{LCl}$ - Letra de Crédito Imobiliário

LEHAB - Laboratório de Estudos de Habitação

FUPAM - Fundação para Pesquisa Ambiental

MCid - Ministério das Cidades

METROFOR - Metrô de Fortaleza

OGU - Orçamento Geral da União

ONGs - Organizações Não Governamentais

PAC - Programa de Aceleração do Crescimento

PAR - Programa de Arrendamento Residencial

PBHQ-H - Programa Brasileiro de Qualidade de Produtividade

PLANHAB - Plano Nacional de Habitação

PLANHAP - Plano Nacional de Habitação Popular

PMCMV - Programa Minha Casa, Minha Vida

PNDU - Política Nacional de Desenvolvimento Urbano

PNH - Programa Nacional de Habitação

PNHU - Programa Nacional de Habitação Urbana

PNHR - Programa Nacional de Habitação Rural

PROAFA - Fundação Programa de Assistência às Favelas da Região Metropolitana de Fortaleza

RMF - Região Metropolitana de Fortaleza

SBPE - Sistema Brasileiro de Poupança e Empréstimos

SECOVI - Sindicato das Empresas de Compra, Venda, Locação e Administração de Imóveis

Residenciais e Comerciais

SNC - Sistema Nacional de Certificação

SPE - Sociedade de Propósito Específico

SINDUSCON - Sindicato da Indústria da Construção Civil

SFH - Sistema Financeiro de Habitação

SFI -Sistema Financeiro Imobiliário

SNH - Secretaria Nacional de Habitação 
SNHIS - Sistema Nacional de Habitação de Interesse Social

SUDENE - Superintendência de Desenvolvimento para o Nordeste

TTS - Trabalho Técnico Social

UFC - Universidade Federal do Ceará

\section{Lista de Gráficos}

Gráfico 01. Pirâmide de renda e abrangência do mercado formal de moradia

Gráfico 02 - Evolução do SBPE e FGTS

Gráfico 03: Distribuição da demanda por região

Gráfico 04: PMCMV - Contratação por tipo de agente

Gráfico 05: RMF - Contratações do PMCMV por agência financiadora

Gráfico 06: Direcionamento dos recursos aplicados por faixa de renda

Gráfico 07: Proporção do défice no Nordeste, atendido pelas unidades contratadas

Gráfico 08: Lançamentos de unidades por bairro em Fortaleza 2004-2012

Gráfico 09: Seis bairros com maior $\mathrm{n}$. de unidades comercializadas e valores do $\mathrm{m}^{2}$

Gráfico 10: Evolução do valor do $\mathrm{m}^{2}$ nos bairros Passaré, Parangaba, Maraponga e Messejana

Gráfico 11: Evolução dos valores máximos de aquisição para o recurso FAR na RMF

Gráfico 12: Produção da empresa e construtora Montenegro

\section{Lista de Quadros}

Quadro 01- Programas e Ações - Recursos financiamento

Quadro 02: Empresas Incorporadoras que abriram ações na Bolsa de Valores

Quadro 03: Fundos financeiros estruturantes do PMCMV

Quadro 04: Subprogramas, linhas, fontes de recursos e metas

Quadro 05: Cronologia das principais regulamentações e portarias do PMCMV

Quadro 06. Diferenças da legislação para cada faixa de renda

Quadro 07: Agentes e grau de influência no desenho da política habitacional.

\section{Lista de Mapas}

Mapa 01: Evolução da RMF

Mapa 02: Ocupação Espacial da Região Metropolitana de Fortaleza

Mapa 03: Vetores de Fortaleza

Mapa 04: Evolução da Mancha Urbana de Fortaleza - Municípios Cornubados

Mapa 05: Evolução da produção habitacional promovida pelo Estado

Mapa 06: Localização de empreendimentos aprovados junto ao PMCMV (2009-2015) 
Mapa 07: Espacialização dos padrões de valores dos terrenos em Fortaleza

Mapa 08: Concentração da produção para a faixa 2-3 em bairros e externalidades

Mapa 09: Comportamento dos bairros e lançamentos do mercado em 2014

\section{Lista de Tabelas}

Tabela 01: Onze maiores incorporadoras atuantes em Fortaleza em 2002

Tabela 02: Ranking das 100 empresas construtoras do Brasil

Tabela 03: Maiores conjuntos produzidos pelo BNH em Fortaleza

Tabela 04: Total de unidades entregues por Federação, conforme a região na faixa 1

Tabela 05: Total de empreendimentos da RMF contratados pelo PMCMV (2009 a 2015)

Tabela 06: Empreendimentos contratados junto a Fortaleza na etapa I - 2009-2011

Tabela 07: Empreendimentos contratados junto a Fortaleza na etapa II 2012-2015

Tabela 08: Empreendimentos contratados junto a Caucaia e Maracanaú na etapa I 2009-2011

Tabela 09: Empreendimentos contratados junto à Caucaia e Maracanaú na etapa II 2012-2015

\section{Lista de Figuras}

Figura 01: Fluxograma da organização das famílias demandantes

Figura 02: Fluxograma da operacionalização da faixa 1 - PMCMV

Figura 03: Implantação e foto aérea do Conjunto Cidade Jardim em Fortaleza 


\section{Sumário}

\section{Introdução}

Capítulo 01 - A moradia e a recente trajetória da política habitacional: a constituição da lógica da produção privada no Programa Minha Casa Minha Vida

1.1 Considerações teóricas sobre a promoção da moradia. Mercadoria incomum e mercadoria impossível

1.1.1 Formas de provisão da habitação, definições da dimensão pública e privada

1.2. Estado e Mercado na recente Política Habitacional Brasileira

1.2.1 A institucionalização e a dissolução do BNH: o recuo das políticas públicas e

a aproximação de novas formas da política habitacional

1.2.2 O Governo de FHC e a concepção da habitação de mercado: mudanças de paradigmas e a entrada dos novos agentes produtores da habitação popular

1.2.3 Política Habitacional do Governo Lula, a afirmação de um modelo e a

racionalização do habitação popular para o mercado

1.3 O Programa Minha Casa Minha Vida

1.3.1 A conjuntura da criação do marco legal para o PMCMV

1.3.2 A definição do desenho Institucional do PMCMV e sua estrutura financeira 39

1.3.3 A regulação do PMCMV, análise de sua legislação e diretrizes urbanísticas 42

1.3.4 Síntese da análise da legislação.

1.3.5 Operacionalização do Programa Minha Casa Minha Vida: as regras de contratação

Capítulo 2 - A Região Metropolitana de Fortaleza: a formação da Metrópole e sua estrutura de provisão de habitação

2.1 A Região Metropolitana de Fortaleza e suas particularidades

2.1.2 A formação da Metrópole

2.1.3 Tendências no desenvolvimento e expansão da RMF

2.1.4 O Município de Fortaleza: concentração urbana e as dinâmicas

2.1.5 Produção socioespacial de Fortaleza e sua metrópole

2.2 Programa Minha Casa Minha Vida: os agentes envolvidos

2.2.1 O setor privado e a organização do mercado imobiliário

2.2.2 Grandes Empresas Nacionais de Capital Aberto

2.2.3 Grandes Empresas Incorporadoras Locais e Grandes Empresas Construtoras

2.2.4 Pequenas Empresas Locais

2.2.5 Os agentes financeiros e o setor público

3.2.1 Dinâmicas de localização para o mercado de três a dez salários-mínimos 125

3.2.3 Dinâmicas de localização para o mercado de zero a três salários-mínimos 136

3.4 Mudanças sobre a apropriação do espaço e a valorização imobiliária $\quad 150$

4 Considerações finais $\quad 153$

5 Referências bibliográficas $\quad 160$ 


\section{Introdução}

Esta investigação se propõe refletir sobre a política habitacional no Brasil e suas dinâmicas de produção no contexto da Região Metropolitana de Fortaleza. Concentrase, para isso, no período da retomada dos investimentos públicos destinados à habitação, mais especificamente, no período posterior aos anos de 1990, quando acontece redefinições no marco regulatório do setor imobiliário e a retomada de investimentos com a recuperação das principais fontes de financiamento habitacional.

Com o lançamento do Programa Minha Casa Minha Vida - PMCMV, em 2009, o contexto habitacional na realidade brasileira foi reforçado com expressivo aumento de investimentos no setor imobiliário que ampliaram as condições de consumo e de produção de habitações. Percebe-se, com isso, que o PMCMV é um marco na nova configuração que consolida a lógica da provisão privada de habitação popular, motivo que instiga a se investigar as mudanças e implicações na produção habitacional, indagando sobre as formas produtivas e espaciais dos agentes imobiliários junto a esse programa, na cidade de Fortaleza e sua região metropolitana.

A compreensão do agente imobiliário é chave fundamental de leitura e de entendimento pelos quais esta pesquisa intenta se estruturar, uma vez que a produção de habitação revelou, nos últimos anos, concentração nos agentes privados; seja pela quantidade de propostas que estão sob responsabilidade de empresas quanto pelo volume de decisões da política habitacional que acaba sendo repassada para esse setor. Afinal, uma mesma empresa pode, ao mesmo tempo, ser proprietária de terras, incorporadora e construtora, além de mediadora entre financiamento do Estado ao beneficiário, modificando a racionalidade da produção que se diferencia em novos produtos e apropriações do espaço.

Assim, o trabalho se inicia com o entendimento de como se consolida esse contexto favorável à produção privada de moradia popular na recente trajetória da política habitacional brasileira. Almeja-se mostrar as repercussões da nova realidade de provisão habitacional na organização do mercado imobiliário da Região Metropolitana de Fortaleza, identificando seus principais agentes e seus modos de 
atuação, na busca de esclarecer mudanças na forma da produção e apropriação do espaço.

Para alcançar os objetivos a que se propõe, esta investigação recorre a alguns autores (TOPALOV, BALL, ABRAMO, RIBEIRO, FERREIRA), os quais, com base na compreensão dos agentes envolvidos na promoção habitacional, elaboraram conceitos que iluminam questões inerentes à atividade imobiliária e avançam na discussão, à medida que as articulam com a produção do espaço urbano.

Estes autores constituem os principais referenciais bibliográficos desta investigação. Busca-se apoio em Topalov $(1974 ; 1988)$, que sugere uma taxonomia da promoção imobiliária e analisa o caso francês, com base no aumento da complexidade da atividade imobiliária e do avanço das relações capitalistas na produção da moradia e da cidade.

Com a mesma relevância, reporta-se, também, às contribuições de Ball (1986) que, ao elaborar um conceito de sistema de provisão habitacional, considera fortalecer cada momento histórico e espacial particular e dá ênfase aos agentes envolvidos na produção e realização da moradia.

O autor imediatamente mencionado compreende que, fundamentalmente, os agentes sociais não governamentais e as suas maneiras de interação e organização repercutem diretamente em como a habitação é provida.

Tanto Topalov $(1974 ; 1988)$ quanto Ball $(1986)$ ressaltam a necessidade de pesquisas que vão além da esfera da dimensão do consumo. Eles asseveram que, quando restritas ao circuito de circulação de mercadorias, as investigações obscurecem a esfera da produção, sem a qual não haveria a produção do edifício e da cidade. Ball (1988) aponta que essa tendência nos estudos habitacionais produz trabalhos ordenados que se concentram apenas no desenho institucional das políticas públicas e na forma da propriedade da habitação e no seu valor.

As teorias que sustentam esta pesquisa reforçam a necessidade da compreensão do papel dos agentes sociais, seja na produção do espaço urbano como na influência sobre a própria política habitacional.

Com suporte das escolhas do mercado e da razão privada que se propõe buscar as respostas às indagações suscitadas neste ensaio. Reconhecendo a complexidade deste estudo, almeja-se aprofundar este conhecimento, principalmente no que se 
refere à localização dos empreendimentos, visto que, com o lançamento do PMCMV, em 2009, foram concedidas margens para que os mecanismos de mercado decidissem sua espacialização, ou localização no espaço urbano, em um panorama em que a regulação do Estado é marcada por sua fragilidade seletiva, uma vez que o volume de recursos e leis implementadas são frequentemente atualizados e revistos. 0 modo de operar, contudo, parece oferecer à esfera privada as decisões finais da produção, incluindo as escolhas dos terrenos. Percebe-se que, dentro de um mesmo programa, há modos de atuação diversos em que o posicionamento do Estado pode, muitas vezes, ser mais influente ou não. No caso específico a Região Metropolitana de Fortaleza, como é expresso nos capítulos a seguir, é a ação do Estado que possibilita a ampliação efetiva do Programa no território, vencendo dificuldades que o mercado por si não resolve.

Interessa a esta pesquisa refletir sobre as razões produtivas e espaciais dos agentes imobiliários do PMCMV; e, na convergência entre as coerências espaciais e imobiliárias, fazer uma análise da localização dos empreendimentos com origem na espacialização da produção dos empreendimentos contratados pelo PMCMV junto à Caixa Econômica Federal - CEF e ao Banco do Brasil.

Nesse sentido, Ribeiro (1997) e Abramo (2001) contribuem, trazendo a perspectiva para os agentes sociais que coordenaram o processo produtivo e a comercialização do empreendimento imobiliário. Esse é o incorporador imobiliário, pois, quando compra um terreno e detém o financiamento para essa construção e comercialização, torna-se o agente responsável pela determinação do valor da venda por meio das características arquitetônicas, econômico-financeiras e locacionais atribuídas ao imóvel.

Na interpretação de Abramo (2005), em decorrência de inúmeras incertezas e riscos, a atividade imobiliária é intensivamente conduzida a buscar outras oportunidades de aumentar sua lucratividade. Tal perspectiva destaca o estudo das dinâmicas espaciais ou fundiárias, uma vez que a terra é mais que um substrato e se torna uma base em que se permite ensejar lucros.

Mesmo na habitação popular, em que o peso da construção aufere importância - e isso pode ser visto no aumento da escala e na diluição dos custos para a 
solvabilidade dos empreendimentos - é possível pensar em vantagens que extrapolam os lucros oriundos da construção em si. Essa razão pode ser estudada com amparo nas escolhas dos terrenos, em uma perspectiva vinculada a esse substrato per si - a terra, e as infraestruturas nela cristalizadas, entendendo como essa decisão interfere no lucro das unidades habitacionais, visto que esta base é um insumo necessário para a produção da habitação e produz conflitos e entraves próprios dessa condição; e pode ser levada à escala urbana, pois um dos principais temas discutidos a respeito do PMCMV é a periferização da produção habitacional formal, tanto para a faixa de interesse social quanto para aqueles de rendas intermediárias. Nessa ordem, compreende-se o papel das escolhas de localização no estabelecimento de uma ordem urbana. (ABRAMO, 2001).

Observa-se em Fortaleza, de 2005 a 2015, o incremento na produção imobiliária, manifestado no aumento do número de lançamentos e também na diversificação da produção e na apropriação de novas áreas. O avanço dessa dinâmica, além das repercussões na paisagem e no espaço intraurbano, tem grande crescimento no interesse imobiliário e essa interfere diretamente no preço da terra que é transferido para o valor da unidade habitacional. Como consequência, tem-se o deslocamento das faixas de menor renda para regiões mais distantes, onde o mercado não diminua seu sobre lucro, pois o preço da terra permanece sendo mais barato. Essa realidade afeta, também, os setores médios. As melhores localizações tornam-se mais caras e acrescem custos nas unidades, sem que isso signifique a melhoria na qualidade arquitetônica ou urbanística das habitações. (FERREIRA, 2012).

Durante os últimos dez anos, o metro quadrado dos terrenos em Fortaleza quadruplicou e o volume financeiro das vendas foi alargado em números também expressivos. Essa valorização imobiliária, além de interferir no acréscimo de valor dos terrenos e na situação dos estoques de imóveis, altera toda a dinâmica imobiliária, orientando e organizando o crescimento da Cidade.

Considera-se relevante, portanto, compreender as mudanças na produção da habitação popular e seus rebatimentos no espaço da cidade de Fortaleza e sua região metropolitana, no que diz respeito à localização da habitação popular conduzida pela força do mercado. Uma vez que a compreensão do reforço da produção imobiliária e 
da ampliação da valorização fundiária são condições transformadoras da organização do espaço urbano dessa Metrópole e da própria condição para a produção habitacional. Para isso, tomam-se como referências os estudos de Deák (1985), Lefebvre (1986) e Ferreira (2012), em que pese as variações de momentos econômicos de suas formulações; apoiando-se, também, em outros autores como Rufino (2012) e Shimbo (2011), uma vez que discutem o atual momento da reprodução do capital financeiro na atividade imobiliária, levantando a relevância dessa produção, trazendo as discussões da valorização da terra para outras direções e não apenas em relação à infraestrutura urbana e ao acúmulo de riquezas e do trabalho apropriado na terra. Isto porque se percebe em Fortaleza o fato de que terrenos antes totalmente inviabilizados em termos de infraestrutura urbana são ativados pelo mercado após o lançamento do PMCMV.

Esses aportes teóricos são fundamentais na articulação entre a produção imobiliária e o espaço da Cidade, por configurarem o espaço como força produtiva na produção imobiliária. As contribuições de cada um desses autores mencionados iluminarão os importantes aspectos das discussões desta pesquisa, que terá o escopo de sua investigação dividida em duas partes, cada qual com dois capítulos que se relacionam com os objetivos e metodologias específicas.

O primeiro capítulo desta dissertação aborda o funcionamento do PMCMV, como ele é gestado e em que conjuntura é implementado, entendendo que a centralidade do capital imobiliário atravessa e influencia o próprio desenho do Programa. Para sua realização, houve uma pesquisa bibliográfica em autores que abordam a formatação do Programa. Citam-se Cunha (2014) e Fix (2011). Foi procedida, também, uma pesquisa documental do aparato institucional para implementar o Programa, verificando sua legislação e seus principais modos de regulação das escolhas do terreno pelo mercado imobiliário. Traz-se relevância para as contínuas mudanças no desenvolvimento da legislação do Programa, ressaltando aspectos que regulam as definições das localizações. O segundo módulo reporta-se aos agentes locais e à contextualização de Fortaleza e sua Região Metropolitana (RMF), observando o que de particular esse território demonstra. Dois pontos principais são tocados: como o mercado imobiliário se configurava antes do Programa e onde os estoques residenciais eram produzidos, concedendo, assim, bases para entender as 
mudanças realizadas com a produção habitacional do PMCMV. O terceiro segmento mostra a repercussão do Programa em termos das localização dos produtos das faixas 1, 2 e 3, assim como se discutem a espacialização desses produtos e a valorização imobiliária. Neste mesmo capítulo, aporta-se às estratégias de decisão e localização dos empreendimentos para entender os fatores importantes das compras de terreno. Quais as hipóteses? Que as articulações com outros agentes? É promovida a expansão periférica ou não? E, como remate, no último capítulo, as considerações finais que apontam algumas percepções que a pesquisa suscitou e sinalizam sugestões para futuras pesquisas.

A investigação respalda-se em uma abordagem metodológica de pesquisa qualitativa, com informações coletadas em periódicos especializados, folhas jornalísticas locais e entrevistas semiestruturadas com agentes atuantes no mercado imobiliário de Fortaleza, ou com pessoas da Gestão Pública, e mesmo pesquisadores da área que possam esclarecer o tema e preencher eventuais lacunas desta busca. A pesquisa de natureza qualitativa, portanto, considera que o nível da realidade não pode ser meramente quantificado, e leva em conta a interpretação de aspectos de outra ordem, sejam sociais, culturais ou subjetivos.

As entrevistas são meios para captar falas e discursos, na tentativa de desvelar aspectos da produção em que dados e mapeamentos possam alcançar os objetivos desta investigação. De acordo com Mattos (2005), o pesquisador, ao realizar uma entrevista, tem uma lista de questões e temas para serem preenchidos, uma préestrutura ou um guia. Outros autores, como May (2004), chamam atenção para o principal aspecto da entrevista, que é seu "caráter aberto", ou seja, o entrevistado responde às perguntas dentro de sua concepção, mas não significa deixá-lo falar livremente. Gil (2002, p. 120) explica que "o entrevistador permite ao entrevistado falar livremente sobre o assunto, mas, quando este se desvia do tema original, esforçase para a sua retomada". Percebe-se, nesta técnica, que o pesquisador não pode se utilizar de outros entrevistadores para realizar a entrevista, porque é necessário conhecimento sobre o assunto.

Além dos dados qualitativos, a pesquisa recolhe indicadores quantitativos sobre o volume e as características da produção imobiliária em diversos órgãos 
representativos que estudam o setor, em particular, o Secovi, o Sinduscon ${ }^{1}$ e a Câmara Brasileira da Indústria da Construção Civil.

Destaca-se o fato de que, apesar de esses relatórios serem dados secundários, possibilitam a percepção na mudança da produção imobiliária da Metrópole sob exame e são de grande relevância para entender as dinâmicas de que se cuida neste estudo.

É importante realçar o fato de que, inicialmente, junto ao principal órgão mediador do PMCMV, a Caixa Econômica Federal (CEF), foram levantados dados necessários para identificar as empresas mais atuantes e a quantidade de empreendimentos contratados, e, com origem nesses indicativos, poder traçar os caminhos da pesquisa. O substrato de empreendimentos contratados pela CEF também serviu como a principal base de dados para a espacialização das unidades habitacionais, uma vez que identifica a tipologia e a localização de cada empresa.

Os indicadores primários e as entrevistas realizadas junto às empresas são utilizados em etapas distintas, que correspondem a vários momentos da pesquisa. $\mathrm{Na}$ primeira fase, em janeiro de 2013, se iniciou uma busca exploratória, na qual se procurou perceber a organização do setor imobiliário para a produção da habitação popular. Quem seriam os principais agentes em Fortaleza? Quais as características particulares da região? Quais os principais conflitos aparentes?

Na segunda fase, buscou-se efetivar uma pesquisa descritiva ${ }^{2}$, a qual já se concentrou nas relações de produção da habitação sob o domínio do seu agente central, as empresas construtoras e incorporadoras. Com apoio em uma seleção das empresas que atuaram no PMCMV, sendo um dos critérios a participação anterior ao programa habitacional PAR, foram reunidas várias empresas que, durante a vigência do PMCMV, tiveram empreendimentos aprovados junto à CEF.

${ }^{1}$ O Sindicato das Empresas de Compra, Venda, Locação e Administração de Imóveis Residenciais e Comerciais e o Sindicato da Indústria da Construção Civil, respectivamente.

2 o processo da pesquisa descritiva visa identificacão, registro e análise das características: fatores ou

2 o processo da pesquisa descritiva visa identificação, registro e análise das características; fatores ou variáveis que se relacionam com o fenômeno ou processo pesquisado. Esse tipo de investigação pode ser entendida como um estudo de caso onde, após a coleta de dados, é realizada uma análise das relações entre as variáveis para posterior determinação dos efeitos resultantes em uma empresa, sistema de produção ou produto. Para mais informações sobre essa método, consultar o Manual da Metodologia Científica, Dalton Gean Perovano, 2014. 
Nessa etapa, apesar de focar no agente imobiliário que conduz suas formas de produção, uma vez que são identificados conflitos na produção da habitação, principalmente, em razão das novas articulações inauguradas com a legislação do PMCMV etapa II - Lei $12.424^{3}$ e Portaria n. $168^{4}$ se viu a necessidade de agendar algumas entrevistas com agentes do Poder Público, notadamente, as instituições garantidoras de infraestrutura urbana (CAGECE) e os órgãos de licenciamento e aprovação.

Realizou-se, ainda, a terceira etapa das entrevistas, quando foram preenchidas algumas lacunas encontradas no ensaio. Foi um momento de entrevistar professores e especialistas que discutem sobre a produção habitacional e imobiliária na Cidade.

Ressalta-se que o levantamento e a revisão bibliográfica ocorrem durante todo o desenvolvimento da investigação, tanto a princípio, para se delinear o estado da arte do tema focalizado e permitir a preparação da busca descritiva, quanto no decorrer dos trabalhos, para suprir deficiências.

Os procedimentos metodológicos basearam-se em entrevistas semiestruturadas com os agentes imobiliários e observações com suporte no estudo da produção dos estoques urbanos, aquilo que é produzido e materializado na Cidade. Com origem nesse caminho, foram discutidos alguns resultados da produção habitacional do PMCMV na RMF, considerando o agente imobiliário como elemento chave para entender as apropriações do espaço e da própria delimitação do Programa na Metrópole.

\footnotetext{
${ }^{3}$ A Lei 12.424 inaugura a criação da segunda etapa do PMCMV, juntamente com decretos e normativas atualiza os valores previstos para tetos das unidades e estabelece novas regras que ajusta faixa de renda, amplia metas e escopos, facilitando a produção para a faixa 1 . Além de reformular normas, aumenta o porte dos empreendimentos.

${ }^{4}$ Após a determinação da Portaria 168/2013, nova regra permite que beneficiários recebam os equipamentos de educação e saúde com maior agilidade, assim como autoriza a contratação dos empreendimentos do PMCMV como equipamentos sociais.
} 


\section{Capítulo 01}

A recente trajetória da política habitacional: a constituição da lógica da produção privada no Programa Minha Casa Minha Vida.

1.1 Algumas considerações teóricas sobre a promoção da moradia. Moradia: mercadoria incomum e mercadoria impossível.

Falar do que é habitação, percebendo suas principais características e implicações na promoção, produção e consumo, além de entender a sua importância para a produção do espaço urbano, requer, na concepção deste esboço, um resgate de debates dos anos 1970/80, que perpassam estudos de pensadores do urbano, como Christian Topalov, Ermínia Maricato, Michael Ball, entre outros.

Apesar de a habitação ser um objeto, um produto que se compra e se vende no seu próprio espaço de produção e de consumo - o mercado imobiliário - ela se destaca por denotar especificidades. Os estudos que dão inteligibilidade às suas características, independentemente da abordagem metodológica, apontam para o lento período de produção, o prolongado consumo e circulação, o alto custo do bem imóvel e, também, a fixidez no espaço. Esta demarca um fator importante - a moradia requer um pedaço de terra como condição básica para a sua produção - ou seja, são indissociáveis a moradia e as condições de sua localização. A propriedade fundiária e imobiliária, assim como as características de urbanização, constitui-se como objetos de sua valorização ${ }^{5}$. Nota-se, então, que as possibilidades de alavancar lucros não resultam apenas de aspectos inerentes à exploração do trabalho na materialização da habitação, mas, também, de elementos externos à construção do objeto em si, como localização, infraestrutura, condições de urbanização etc. Os sobrelucros podem ser extraídos, sem que haja necessariamente o envolvimento de um capital produtivo na propriedade. $E$ essa característica só é possível de ser entendida quando se considera que o consumo

\footnotetext{
${ }^{5}$ Ressaltam-se estudos sobre as apropriações privadas dos bens comuns que foram denominados como 'mais-valia urbana', uma valorização provocada pelas intervenções públicas, orquestradas pelo Estado. As abordagens marxistas do urbano exprimem que a valorização das localizações se dá coletivamente por meio do trabalho exercido sobre a base material da cidade.
} 
ou a produção da moradia é também o consumo e a produção do espaço urbano, o que as vincula às oscilações das dinâmicas urbanas ao longo do tempo.

Enquanto o preço de outras mercadorias resulta de um esquema definido pelo emprego de um capital fixo e de um capital circulante somado a uma taxa de lucro e regulada pela oferta e procura, os preços das localizações não podem ser definidos individualmente como se fossem quaisquer mercadorias. É Deák (1992) que nos leva a compreender que eles só podem ser produzidos coletivamente. As localizações individuais decorrentes da produção habitacional e colocadas no mercado coletivamente têm seu preço definido pela competição capitalista.

A apropriação da terra, circunstância para a realização da moradia, à medida que se torna objeto da disputa de rendas, também é um limite para a própria reprodução do mercado imobiliário, uma vez que cada novo empreendimento faz uso de um estoque limitado de terrenos disponíveis. Se, por um lado, a competitividade e a valorização da propriedade existem como um freio para o aumento da produção, a apropriação da terra, de outra parte, também permite a apropriação de sobrelucros fundiários. Como bem destaca Martins (1983), assim como a propriedade dos meios de produção admite a apropriação dos lucros industriais, a propriedade da terra permite lucros na produção de moradia. É a retenção fundiária e a concentração de grandes estoques de terrenos que permitem as transformações em larga escala nos espaços urbanos, orientando os tais sobrelucros de localização ${ }^{6}$.

A produção da habitação é bastante complexa. Entende-se, aqui, como produção, a materialização da moradia; ou seja, a sua construção propriamente dita e o seu trabalho no canteiro. A produção de habitação se particulariza pelo fato de requerer uma grande quantidade de insumos e matérias-primas, podendo ser esses mais ou menos industrializados. Envolve, também, grande diversidade de atividades e de trabalhadores, podendo ser esses mais especializados ou não. E, por fim, exprime uma longa e complexa cadeia produtiva de trabalho.

\footnotetext{
${ }^{6}$ Esse termo aparece em vários trabalhos, tendo como referência Topalov (1974), que investigou os agentes da promoção imobiliária no Estado francês. O autor detectou a emergência de mudanças na forma de produção e introdução de novos agentes, como a figura dos promotores imobiliários. Eles regulam várias etapas da promoção imobiliária, entre elas, as atividades fundiárias. Os agentes capitalistas valorizam seus capitais por meio da utilização e da transformação do solo urbano. As oscilações do preço da terra constituem um reflexo desta disputa, que permitem estratégias para emergir os "sobrelucros de localização".
} 
O interesse desta pesquisa, no entanto, é compreender que, no longo ciclo de produção, serão exigidas grandes somas de capitais imobilizados, sejam para a manutenção da força de trabalho, sejam para a compra dos insumos necessários à construção, ou mesmo para a aquisição de seu terreno. O alto volume de capital investido ao longo do tempo na complexa produção resulta em uma mercadoria de alto valor agregado e elevado preço, o que a torna um dos bens mais caros do consumo privado capitalista; e, por isso, exige algum tipo de financiamento específico para a sua aquisição.

Ao considerar as características ora mencionadas, é relevante destacar o estudo das formas de financiamento habitacional, que possibilita o consumo capitalista da habitação como mercadoria. Os modos de financiamento repercutem nas condições de consumo da habitação e afetam, ainda, o produtor e a sua capacidade de alavancar recursos, o que interfere no meio como os agentes se organizam ante as novas possibilidades de captar e ampliar lucros.

Sob essa óptica, o acesso ao financiamento repercute diretamente nas taxas de lucro, uma vez que o período extenso de rotação de capital na realização de um imóvel é por demais longo - aspecto que se torna desvantajoso para o investidor por imobilizar recursos e insumos para construir habitação a fim de manter a força de trabalho.

Detalhando e ampliando esses entraves, reporta-se a Ribeiro (1991), que contribui com a problematização das ofertas de crédito e da disponibilidade de terras urbanizadas necessárias à mercadoria incomum.

O financiamento depende de condições econômicas e financeiras especiais que permitam o surgimento de um sistema de crédito ligado a um bem cujo valor relativo é alto, numa sociedade que tende a estabelecer a renda do conjunto da população ao nível das necessidades imediatas de reprodução da força de trabalho. Consequentemente, fazendo com que o acesso mercantil à moradia dependa de a demanda torna-se solvável via endividamento. A oferta da terra urbanizada, isto é, conectada ao sistema de equipamentos, infraestrutura e serviços urbanos que complementam a utilidade da moradia enquanto valor de uso complexo depende da interação de vários mercados (de solo, de obras públicas etc.) e da prestação direta ou indireta pelo poder público de certos serviços urbanos. (RIBEIRO, 1991, p. 475). 
Uma vez que a dinâmica da produção da moradia depende da oferta de crédito, capaz de financiar seu longo processo de construção e de comercialização, bem como da oferta de terras urbanizadas, a moradia se torna um bem de acesso difícil, expressando-se à maioria de seus consumidores como 'mercadoria impossível', utilizando a expressão de Jaramillo (1980).

Esse autor externa a ideia de que, para se estabilizar o capital produtivo da atividade imobiliária, é exigível um capital de circulação independente que suprirá as necessidades de financiamento na produção. Esse capital possibilitará, simultaneamente, o acesso ao crédito e à distribuição e circulação desse bem.

A ampliação do mercado formal de moradias passa necessariamente pela atividade e intervenção estatais, e é enorme e socialmente visível a imbricação das reestruturações do setor construtivo e imobiliário com as intervenções do Poder Público no Brasil. Há uma 'forma histórica' em que o Poder oficial trata com permissividade, constituindo uma aliança com o setor imobiliário.

O PMCMV ilustra bem a consolidação de um fenômeno que, extraordinariamente, incrementa o setor imobiliário por meio de políticas e investimentos públicos. Antes, porém, de analisar as transformações recentes que fomentaram o Programa, bem como a aproximação do setor imobiliário à produção de moradia popular, faz-se necessário discutir algumas teorias que colaboram com este estudo. São aportes teóricos que tratam das dimensões públicas e privadas na produção habitacional, porquanto se torna difícil distinguir as esferas públicas e privadas da própria política habitacional.

Shimbo (2010) enfatiza a indistinção das fronteiras no modo de provisão da habitação entre as instâncias: dimensão pública e privada. Em sua tese Habitação Social, Habitação de Mercado, essa autora destaca a atual configuração da política habitacional, incluindo o PMCMV, e articula, simultaneamente, Estado, mercado imobiliário e capital financeiro na provisão de moradia.

Posta essa indistinção, a autora ora mencionada sinaliza o fato de que são destinados recursos públicos para o fomento da habitação popular, no entanto, o controle da demanda, a definição da localização e a forma da produção podem ser decididas na esfera privada. É, modelo de negócio das empresas, esta dimensão particular que passa a se articular com o Programa, definindo e redefinindo os próprios 
limites da política habitacional para garantir o interesse do agente privado e assim garantir sua efetivação, fortalecendo a coesão dessas duas dinâmicas, público e privada, que se propôs se discutir abaixo.

\subsubsection{Formas de provisão da habitação, dimensões pública e privada.}

Em uma realidade marcada pelas mudanças políticas, ideológicas e econômicas dos anos de 1970 para a década seguinte, com o recuo da socialdemocracia na Europa e no Mundo, Ball (1988), em Housing and social change in Europe and the USA, investiga a política habitacional influenciada pelas tendências neoliberais na provisão habitacional. O autor verifica que, até mesmo no caso dos EUA, postulado como forma paradigmática da proposta liberal, o mercado era assistido por participação ativa na montagem do sistema financeiro para a produção de habitações.

Embora haja mudanças e substituições nas intervenções do Estado sobre a produção habitacional, isso não significou, de modo algum, a retirada de sua presença ou atuação. Na prática, os governos continuaram a interferir na economia e na questão social, conquanto essas intervenções sejam impregnadas de uma ideologia orientada para o mercado.

Via de regra, o Estado sempre esteve envolvido na provisão habitacional produção e promoção -, seja coordenando as políticas habitacionais ou as políticas de financiamento que possibilitam a realização do setor habitacional. Abramo (1995), sobre a produção capitalista da moradia, distingue três grandes formas: produção estatal, sustentada e autônoma.

O autor acima citado explica que a diferença entre a produção capitalista sustentada e a autônoma não se estabelece por manter ou não vínculos com as estruturas estatais. Essa diferença se manifesta nos modos como a oferta capitalista deve obedecer para ter acesso a certas prerrogativas que introduzem as regras nos critérios do livre jogo da concorrência do mercado, a exemplo de taxas inferiores às do mercado financeiro.

Se, por um lado, o Estado restringe a liberdade na decisão de organizar a produção, de outra parte, limita as incertezas de realizar essa produção. Esses mecanismos permitem que a mercadoria habitação entre em vantagens comparativas em relação às outras mercadorias-moradias. 
A despeito de esta pesquisa ancorar-se em autores que concordam com a impossibilidade de uma produção capitalista de moradias que não se vincule de algum modo às estruturas estatais, existe na literatura uma tentativa de separação e taxinomia do que seria efetivamente uma promoção pública e privada da habitação, esse didatismo é interessante para entender em quê o Programa Minha Casa Minha Vida atualiza essas relações.

Sob as razões públicas de habitação - a produção estatal - entende-se o Estado como o principal agente da produção, cumprindo o papel de incorporador, articulador e definidor das principais decisões e ações para a produção da moradia. Essa atuação direta do Estado, historicamente, aconteceu em habitações em que o mercado não garantia sua solvabilidade. Nesse tipo de produção, o Estado define praticamente todo o ciclo da produção - desde as localizações, com as aquisições de terras, passando pela delimitação da demanda, com a escolha do público-alvo e do projeto, até chegar à origem dos recursos para a construção das unidades habitacionais e a contratação das empresas construtoras.

Bonduki (2003) distingue a "habitação de interesse social" da "habitação de mercado popular", por entender que a produção e o consumo por vias de mercado não estão sujeitos ao mesmo critério de planejamento e implementação que os produzidos pelo Poder Público. Além da distinção da forma em que a mercadoria é planejada e produzida, faz diferenciação no próprio horizonte social das duas maneiras de produção de moradia, porquanto a racionalidade privada busca o retorno de investimentos e a solvabilidade do empreendimento. Ao Poder Público, resta a capacidade de garantir a universalização do direito à moradia.

Como visto, na habitação - uma mercadoria cara sob quaisquer critérios - o capital privado tende a priorizar a demanda solvável, isto é, produzir quase que tão somente para as camadas sociais que podem pagar e garantir seus almejados lucros. Nesta perspectiva, a habitação social na omissão ou na quase ausência do capital privado para sua produção, dentro dos padrões de formalidade e da legalidade, com efeito, só foi preenchida pela dimensão pública e programas habitacionais, não interessaria ao mercado, não conseguiria ser rentabilizado pela racionalidade capitalista, esperaria a intervenção do Estado para solver o problema, nas formas de 
tornar a habitação popular um nicho interessante ao mercado ou atuar de forma direta em sua produção.

Seguindo ainda a orientação de Abramo (1995), no que se convencionou chamar de produção sustentada, em uma derivação do papel do Estado, este pode assumir a função de bancos no financiamento habitacional, pode regular a política de crédito habitacional, controlando fundos públicos e semipúblicos, assim como interferir na tributação do setor, entre outras práticas que alteram e orientam significativamente a produção privada de habitação.

Essas mudanças favorecem investimentos no setor imobiliário e ampliam condições de consumo da habitação que, de maneira geral, intensificam o quadro de produção imobiliária no território. Elas são, muitas vezes, associadas a uma crescente valorização imobiliária, que afeta diretamente os valores dos terrenos e os estoques habitacionais.

Na produção sustentada, quando prevalece a razão privada em que o fim é a reprodução do capital e a maximização dos lucros, onde atua, propriamente dito, o "mercado capitalista de habitação", ainda que haja investimentos públicos ou incentivos por parte do Estado, a apropriação dos lucros é privada. A produção privada sustentada e a produção autônoma se diferenciam justamente na captura dos recursos, podendo ser eles exclusivamente privados ou subsidiados pelo Poder Público.

Conquanto se entendam as instâncias de regulação do espaço, mercado e Estado e a classificação de agentes produtores, sabe-se que, no campo empírico, as tentativas de separação dessas dimensões, bem como sua nomeação exata, podem enrijecer a complexidade do tema.

A exemplo desta complexidade, o PMCMV traz uma articulação entre as esferas pública e privada em que se beneficiam, de um lado, o Estado, ao se apropriar dos números da produção imobiliária como parte da política pública e, de outro lado, as empresas imobiliárias, incorporadoras de grande autonomia no que diz respeito às tomadas de decisões do fazer habitacional.

Embora haja capilaridade de um programa que tem investimentos públicos e convergência entre agentes públicos e agentes privados na operacionalização dessa produção, percebe-se que foi deixada aos mecanismos de mercado a decisão acerca 
de localização, concepção, produção e, muitas vezes, comercialização ${ }^{7}$ dos empreendimentos. Esse mecanismo consolida a dimensão privada e fortalece como centralidade dessa produção as grandes empresas e as construtoras.

Grifa-se aqui, mais uma vez, a noção de que, com isso, o Estado não se ausenta dessa realidade. Ao contrário, não se veem, desde os anos de 1980, com o desmonte do $\mathrm{BNH}$, tantos recursos públicos a fundo perdidos destinados para a política habitacional. Essa disponibilidade inaugura um período já consagrado como "de retomadas dos recursos públicos" que culmina com o lançamento do Programa Minha Casa, Minha Vida, em 2009, que, atualmente, alcança a marca de 4,2 milhões de unidades contratadas ${ }^{8}$. Essas contratações correspondem a mais de 10,4 milhões de beneficiários que estão distribuídos em 96\% dos municípios brasileiros, ou seja, em 5.330 cidades.

Ball (1988) indica que, fundamentalmente, os agentes sociais não governamentais e suas formas de interação e organização repercutem em como a habitação é provida, para quem ela será provida, quanto custará essa provisão e como será subsidiada pelo Estado. São os agentes sociais, nesse enfoque, que podem ser proprietários de terras, construtores, financiadores, ou mesmo um só agente que controla as atividades antes executadas por parte de cada um destes.

A perspectiva de análise que enfoca a estrutura da provisão com suporte nas relações entre os agentes que a compõem é uma compreensão de Ball (2006). Ele sugere o conceito de "estruturas de provisão habitacional". Mais do que um conceito, é também um instrumento com origem na qual seria possível compreender as formas de provisão habitacional. Ao passo que enfatiza as esferas de produção e provisão, o autor critica as análises focadas nas dimensões do consumo, que voltam a perspectiva apenas para o desenho institucional da política pública.

Fez-se necessário contrapor as explicações da estrutura de provisão de moradias orientadas exclusivamente pelo desenho político. Os autores citados realçam a noção de que, em estudos habitacionais, não se pode ignorar a substancial transformação de toda a estrutura de provisão que se relaciona com o

\footnotetext{
${ }^{7} \mathrm{Na}$ faixa de renda de 0-3 SM, as variáveis abertas são o preço do terreno e da construção, uma vez que o preço das unidades é fixo e a distribuição não é por vias do mercado e, sim, pela Caixa Econômica Federal, em parceria com o Poder Público, que cadastram e definem os beneficiários.

${ }^{8}$ Fonte Ministério das Cidades, consulta no site do Governo Federal, em março de 2016
} 
desenvolvimento das estruturas do mercado da construção e do setor imobiliário. Considerar os agentes sociais e os produtores imobiliários na provisão da habitação seria, pois, uma necessidade para esta pesquisa, que procura a aproximação desses agentes, buscando suas lógicas de produção como chave para entender a política habitacional.

Dizer que o mercado de habitação cresceu e se generalizou equivale a considerar que a penetração da racionalidade capitalista no setor habitacional se difundiu e aprofundou. A habitação tornou-se, em grande medida, uma mercadoria um valor de troca - o correspondente sistema de produção sobressaindo perante os sistemas comandados por outros raciocínios, como ocorre com uma produção não mercantil, em que o agente central é o próprio usuário, sendo a habitação um valor de uso; ou como a rentista, em que o próprio dono do terreno protagoniza as atividades que culminam na edificação para posterior venda ou aluguel.

A racionalidade capitalista no setor imobiliário aparece, sobretudo, encarnada na figura do promotor ou incorporador, tornando agente fundamental da configuração do espaço urbano ao lado de outros, como os que operam a produção e a circulação de mercadorias em geral, os proprietários e/ou possuidores de terrenos e o próprio Estado.

É comum nos estudos sobre habitação se dar enfoque central às condições de consumo da moradia. Há uma neutralização e uma apropriação deste entendimento no discurso dos agentes envolvidos na produção imobiliária, consoante Topalov (1974). Essa locução fortalece a reprodução do discurso comum, em que a demanda é responsável por todas as mudanças na produção imobiliária. Ao anular, naturalizar ou diminuir a atuação dos diversos agentes envolvidos e desconsiderar as particularidades da produção imobiliária, este entendimento se fez obstáculo para a compreensão da complexidade das mudanças da produção imobiliária e das suas consequências na produção do espaço.

Abramo (2007) enfatiza as ações dos empresários urbanos. Seus procedimentos metodológicos costumam se fundamentar em entrevistas semiestruturadas com os empresários urbanos e observações baseadas no estudo da produção dos estoques urbanos, aquilo que é produzido e materializado na cidade. Este autor tem um posicionamento que indaga a ordem urbana que os mercados conduzem, e, ainda que 
não apresente um trabalho no campo do planejamento urbano, uma vez que foca seu estudo nas dinâmicas do mercado, seus resultados têm como perspectiva servir aos estudos sobre o ordenamento do território.

O PMCMV, como será visto, denota uma série de características que o situam em uma condição de mercado muito específica. É um programa com produtos distintos e que atende diversos segmentos de faixa de renda, e, dependendo do público e produto a ser produzido, as regras do jogo mudam.

Apesar do grande volume de crédito e de recursos para o financiamento da produção, atuar junto ao PMCMV requer desses empresários urbanos uma série de estratégias específicas a serem delimitadas. A atuação dos empresários diferencia-se do mercado tradicional, as atividades de comercialização praticamente inexistiam na faixa voltada ao segmento de mais baixa renda, o valor do preço do terreno era associado ao teto do custo de produção, o próprio valor do teto, ou seja, o valor máximo das unidades habitacionais é ponto de conflito, discussões e reajustes, uma vez que lida diretamente com o lucro das empresas envolvidas na produção dessa habitação.

É da primazia da atividade imobiliária a busca por novas oportunidades de aumentar sua lucratividade; é também imprescindível a produção associada à terra urbana, não havendo, assim, uma produção que seja desassociada de estratégias espaciais e oportunidades fundiárias.

Antes de buscar discutir quais as ações desses empresários urbanos, que se expressam ante inúmeras incertezas e novas dificuldades estabelecidas pelas regras do jogo do novo mercado que se abre com o lançamento do PMCMV, cabe debater primeiro a própria abertura desse mercado de habitação popular, compreendendo os conflitos produzidos no momento em que as regras de atuação desses agentes são estabelecidas, e, entender a própria influência do setor no desenho do programa habitacional. Ainda que, brevemente, interessa a esta pesquisa investigar o contexto histórico das políticas habitacionais na tentativa de recuperar as mudanças que favoreceram a efetiva entrada da lógica do negócio na provisão da habitação popular. Tal aspecto será abordado a seguir, partindo de uma perspectiva acerca da dissolução do BNH e o vazio deixado nas políticas públicas de habitação social. 


\subsection{Estado e Mercado na recente Política Habitacional Brasileira}

\subsubsection{A institucionalização e a dissolução do BNH: o recuo das políticas} públicas e a aproximação de novas formas da política habitacional.

Ribeiro (1991), em seus estudos atinentes ao setor imobiliário, reconstitui as origens da incorporação imobiliária e indica que, nos anos de 1940, ela já existia. A ausência de instituições financeiras, porém, que permitissem uma captação sistemática de fundos e poupanças para o financiamento da atividade imobiliária, e os desvios de recursos para as previdências sociais, impediam a realização plena e a consolidação de um capital de incorporação no Brasil. Era uma demanda dos grandes empresários a de pressionar o Estado para montar uma política habitacional com uma estrutura financeira organizada a disponibilizar recursos para a expansão e a organização do setor imobiliário no País.

Paralelamente às pressões do mercado, aconteciam a consolidação e a ampliação das periferias como lugares da moradia da população de baixa renda. $O$ avanço da favelização nas cidades em decurso de industrialização se intensificava e marcava o aprofundamento da crise, dando força ao discurso de redução do défice habitacional em todo o Brasil.

Como resposta a essas demandas, foi pensado o Sistema Financeiro de Habitação - SFH, formulado como um modelo de financiamento para estabelecer fontes de recursos permanentes para financiar sistematicamente a produção de moradia no País; um sistema que captava tanto poupanças compulsórias (FGTS) quanto voluntárias (cadernetas) e as dispunham aos seus agentes produtores específicos.

A operacionalização da política habitacional organizada pelo BNH sucedia pela segmentação do mercado, segundo o nível de renda familiar em que cada grau estava atrelado a um agente promotor específico - a faixa que concentrava as famílias de maior renda, chamada de "Faixa de mercado médio", havendo beneficiários que ganhavam desde seis salários-mínimos.

Tal segmento era conduzido pela atuação privada, sem participação direta de nenhuma das companhias e órgãos públicos criados para dar suporte aos programas de promoção habitacional. Para as faixas de menor renda, as quais tinham menor 
solvabilidade, a promoção era majoritariamente pública e ficava a cargo das companhias habitacionais (COHABs), que eram agentes regionais do órgão central, 0 Banco Nacional da Habitação - BNH. Apesar de a produção ser conduzida e decidida pelos órgãos públicos responsáveis, muitas vezes, a produção - o processo da construção de per se - era conduzida por empresas privadas contratadas.

Na perspectiva de Amorim (2010), a estrutura dos agentes públicos promotores das políticas do BNH no âmbito do Governo do Estado do Ceará eram as companhias de habitação - COHABs que, inicialmente, se expressavam como instituições voltadas a projetos fora da Capital do Estado (COHAB-CE) e depois orientadas para as realizações na Capital (COHAB-FOR), posteriormente, fundidas em um só órgão, que manteve sua estrutura até sua extinção em 1999. Na esfera do Município sob exame, a Fundação de Serviço Social de Fortaleza - FSSF e; no contexto regional, o Instituto de Orientação das Cooperativas Habitacionais do Ceará, Piauí e Maranhão - INOCOOP-CPM.

Apesar do êxito numérico do BNH, que, segundo Azevedo (1988), viabilizou cerca de 4,5 milhões de unidades em 22 anos de política habitacional, grande parte do público-alvo pertencente ao maior défice permaneceu não privilegiado.

Como explica Maricato (1984), a faixa de interesse social teve uma série de dificuldades de ordem institucional e econômica para ser inserida na política habitacional, visto que grande parte de seu universo demonstrava fragilidade para quitar as prestações cobradas pelo financiamento estatal, ao passo que, na faixa de maiores rendas, crescia o número de unidades oferecidas pelo mercado. $O$ setor imobiliário e a indústria da construção logravam maiores lucratividades pela maior capacidade de financiamento e retorno dos capitais aplicados pelo SBPE, dando às atividades do BNH um caráter economicamente elitista.

1.2.2 O Governo de FHC e a concepção da habitação de mercado: mudanças de paradigmas e a entrada dos novos agentes produtores da habitação popular.

Shimbo (2010) e Arretche (2002) concordam na ideia de que foi no governo FHC que houve efetivamente uma mudança na estruturação da política habitacional brasileira. A alteração de paradigma não só ampliou a participação do mercado na 
provisão da habitação, como também teve como princípios a aproximação das políticas públicas aos valores de mercado.

Como analisa Arretche (2002), na prática, a agenda de reformas do Governo FHC revisou o paradigma do Estado concentrador, por meio da descentralização da alocação dos recursos federais para introduzir outros princípios de mercado na provisão. Dentre eles, abriu espaço para a participação do setor privado, além de inserir uma política de crédito para o mutuário final.

Ante os princípios de flexibilização e descentralização, alguns avanços também foram apontados na política habitacional de FHC. Caracterizada pela aproximação aos municípios, essa política auxiliava na compreensão dos problemas e das dimensões da cidade real. Maricato (1998), apesar de grande crítica desse desenho de política habitacional, aponta como positivo o reconhecimento das dimensões e das condições de legalidade e ilegalidade tão características da urbanização no Brasil.

Já Lorenzetti (2001) destaca a noção de que a descentralização operacional e a diversidade de programas permitiram nova abordagem ante o défice habitacional, que então seria compreendido com facetas diversas, incorporando várias precariedades habitacionais.

As principais ações do Programa Nacional de Habitação (PNH) anunciadas no Governo FHC estruturavam-se em três eixos de ações principais. O primeiro integrava programas destinados ao financiamento para recuperação de áreas habitacionais degradadas e ocupadas por populações com renda de até três salários-mínimos, em alguns casos, a fundo perdido. Essas ações financiavam tanto a construção de unidades quanto reformas habitacionais, ou mesmo intervenções na estrutura urbana. Os principais programas eram: o Pró-Moradia e o Habitar-Brasil, que não ganharam amplitude pretendida, por denotarem elevado grau de inadimplência junto a alguns municípios.

No segundo eixo, estavam os programas voltados para a melhoria do funcionamento do mercado de habitações ou "enablingmarket policies", orientados para famílias com renda superior a 12 salários mínimos. Esses programas focavam na reformulação de legislações, objetivando o desenvolvimento institucional e tecnológico do setor. Para isso, foram criados o Programa Brasileiro de Qualidade e 
Produtividade Habitat, o Sistema Nacional de Certificação e o Sistema Financeiro Imobiliário (SFI).

O SFI foi instituído no contexto dos anos de 1990, precisamente em 1997, época em que o mercado imobiliário, vindo de um longo recesso de investimentos para o fundo de habitação, procurava atuar com o emprego de recursos próprios e de mecanismos de autofinanciamento. A produção autofinanciada indicava um modelo em que se concentrava nos segmentos de maior poder aquisitivo e realizava empreendimentos de menor escala. Nessa época, os órgãos representativos do setor da habitação passavam a buscar formas opcionais para construção, além de promover debates sobre financiamentos com orientação em modelo estadunidense. O SFI, portanto, se diferenciava dos moldes do tradicional SFH brasileiro. Suas influências vinham da experiência ianque em que se previa no novo sistema uma série de garantias e de mecanismos que aproximavam o mercado imobiliário ao modelo de mercado financeiro, ou mercado de capitais, viabilizando o mercado secundário de títulos. Destacam-se: os Certificados de Recebíveis Imobiliários (CRI) ${ }^{9}$, a Letra de Crédito Imobiliário ( $\mathrm{LCl}$ ) e a Cédula de Crédito Imobiliário (CCl), que foram os novos e os importantes mecanismos de securitização imobiliária.

O avanço da financeirização ${ }^{10}$ do setor imobiliário auferiu reforço em 2004, com a aprovação da Lei n. 10.931, conhecida como "Lei do Patrimônio de Afetação", promulgada com o intuito de preencher falhas para o pleno funcionamento do SFI.

A nova legislação estendeu a alienação fiduciária para imóveis urbanos. A alienação fiduciária facilitava a recuperação do imóvel por parte dos credores em caso de inadimplência dos mutuários. A lei pode ser entendida como um formato de "propriedade" transitória, em que o domínio da posse só seria efetivado com a liquidação da dívida.

No instrumento conhecido como "Patrimônio de Afetação", no entanto, cada empreendimento é isolado dos ativos da empresa construtora ou incorporadora. Ao

\footnotetext{
${ }^{9}$ Os CRI'S são descritos na Lei N. 9.514, que criou o SFI como "títulos de crédito nominativo, de livre negociação, lastreados em créditos imobiliários e constituem promessa de pagamento em dinheiro". A empresa construtora ou incorporadora poderia, por meio desse mecanismo, securitizar as dívidas dos mutuários que compraram unidades habitacionais e vendê-las no mercado como promessa de pagamento.

${ }^{10} \mathrm{O}$ conceito de financeirização se relaciona com a fase do capitalismo em que as transações e mercados financeiros ganham força no sistema econômico. Autores como Chesnais (2002) e Harvey (2004) são os principais nomes que ajudam a entender a discussão dessa teoria.
} 
separar a contabilidade do empreendimento, diminuem-se os riscos ao investidor e funcionam como mecanismos de proteção ao financiamento. Com essas medidas era reforçado o avanço da financeirização do setor imobiliário.

Já o terceiro eixo do PNH - Governo FHC - se constituía por programas de financiamento a longo prazo, destinados à população com renda familiar de três a 13 salários mínimos. Tinha em suas modalidades de funcionamento o apoio à produção e, em uma delas, o crédito chegava ao consumidor para financiar material de construção ou a compra de um imóvel usado. Outra possibilidade era o uso da Carta de Crédito Associativo que, utilizando recursos do FGTS e SBPE, foi a principal fonte para fomentar a produção de mais unidades. O quadro abaixo recupera os programas vigentes voltados para a habitação, bem como suas fontes de recursos.

Quadro 01: Programas e Ações - Recursos financiamento

\begin{tabular}{|cc|cc|}
\hline \multicolumn{2}{|c|}{ Programa - Ação } & \multicolumn{2}{|c|}{ Programa - Ação } \\
\hline Habitar Brasil & OGU & Carta de Crédito Associativo & FGTS \\
Pró Moradia & FGTS & Apoio a Produção & FGTS \\
Habitar Brasil - BID & FGTS + BID & Programa de Arrendamento & FAR \\
Programa Pró Saneamento & FGTS + BID & PSH - Carta de Crédito Individual & OGU \\
Carta de Crédito Individual & FGTS & FSH - Imóvel na Planta ou & OGU \\
\hline
\end{tabular}

Fonte: CEF e Ministério das Cidades. Organização própria.

Os programas dirigidos à baixa renda realizados nos anos de 1990 aconteciam tanto por meio dos estados e dos municípios - dando continuidade ao modelo estatal de provisão - quanto pelas linhas de financiamento direto ao mutuário final, que denotava algo novo na realidade da política habitacional até então efetivada. A princípio, o desempenho do Programa de Cartas de Crédito encontrou muita resistência. Em 1997, foram feitas várias adequações e simplificações das burocracias exigidas, além da flexibilização das prefeituras locais quanto às exigências para a regularização de imóveis populares. Nos anos seguintes, o Programa foi absorvendo 
cada vez mais recursos da União, chegando a representar $85 \%$ das verbas administradas de 1995 a $2003^{11}$.

Maricato (1998), sobre as mudanças realizadas no Governo de FHC, sintetiza a ideia de que o Estado não logrou intervir diretamente na política habitacional, tampouco pôs em prática os avanços constitucionais, principalmente, advindos da Constituição de $1988^{12}$, ficando omisso no papel que lhe foi dado - o de regulação. Apesar das virtudes que podem ser destacadas da mudança de um modelo centralizador que vinha desde o período militar, a distribuição dos recursos federais e a concepção de flexibilização abriram caminhos para o setor privado fazer uso do crédito que deveria beneficiar o mutuário final. Uma vez que o setor parte para a lógica privada em que os sobrelucros da política habitacional são apropriados, as camadas de baixa solvabilidade, ou seja, as de menores rendas ficam ainda mais desassistidas.

\subsubsection{Política Habitacional do Governo Lula, a afirmação de um modelo e a} racionalização da habitação popular para o mercado.

É interessante, aqui, iniciar registrando o fato de que o Brasil estava na contramão do recuo social e do avanço neoliberal no Mundo. Justamente nos anos de 1970/80 começam a se formar os partidos brasileiros de esquerda, período em que os trabalhadores fazem lograr a Central Única dos Trabalhadores (CUT). Nascem daí os movimentos sociais urbanos, criando-se a Central de Movimentos Populares (CMP) e o Fórum Nacional da Reforma Urbana (FNRU). As conquistas com a aprovação da Constituição Federal de 1988, institucionalizando o direito à moradia e a promulgação do Estatuto da Cidade, em 2001, constituíam um quadro de expectativas em relação às novas políticas urbanas.

O quadro habitacional brasileiro apontava avanços institucionais ligados aos direitos à moradia e ao desenvolvimento urbano, como respostas às pressões dos movimentos sociais, das academias e das prefeituras.

\footnotetext{
${ }^{11}$ Shimbo (2010) apud dados LABHAB-FUPAM: LOGOS ENGENHARIA, 2007.

${ }^{12}$ A moradia passou a ser um dos direitos sociais concebido e garantido pela Constituição Federal de 1988, em seu artigo 6으, caput. Posto ao lado das necessidades mais básicas do ser humano, o direito à moradia foi institucionalizado e garantido por lei.
} 
O Governo Lula começou seu mandato no ano de 2003, apoiado pelos movimentos de moradia, entre tantos outros movimentos sociais, com a promessa de grandes mudanças no panorama brasileiro. Deu início, entretanto, ao primeiro mandato sustentando intacta a maior parte da política dos governos anteriores em um esforço pela busca de um crescimento econômico e de um fortalecimento da política externa. Durante esse período, até meados de 2006, as orientações do Governo Lula se caracterizaram por um continuísmo no que se refere à política urbana, sendo apenas posterior a essa data a real volta de investimentos na infraestrutura urbana e na habitação. Para a história da habitação e do planejamento urbano, contudo, esse Governo marcou importantes acontecimentos em ações específicas desde o primeiro ano de sua assunção. Destacam-se: a criação do Ministério das Cidades (MCid); a articulação e a realização de conferências nacionais das cidades que se desenvolvem em 2003, 2005 e prosseguiram em outras gestões nos anos de 2007, 2010 e 2013; o desenvolvimento do Plano Nacional de Habitação; a implementação do Programa de Aceleração do Crescimento - PAC I e II; e o lançamento do PMCMV.

Foi no Governo Lula, principalmente após alcançada a estabilidade da política econômica, que começaram a ser divisadas as mudanças nas políticas de desenvolvimento urbano. Nesse período, aconteceu a recuperação de massivos investimentos estatais depois de décadas de passivo investimento no urbano. Recentes estudos destacam, no entanto, é que, ao se recuperar os investimentos na política urbana, houve um descompasso, um momento de inflexão. As propostas iniciais planejadas distanciaram-se do que efetivamente se realizaria nessa política. Depois de anos planejando em como seriam alocados a retomada de investimentos no desenvolvimento urbano, a política do Governo Lula e, posteriormente, do Governo Dilma, tem como principal aspecto o forte teor econômico, subjugando a política urbana, contradizendo e se distanciando dos objetivos que foram traçados como ponto de partida. Isso é claro na própria escolha dos programas que receberiam mais investimentos: o Programa de Aceleração de Desenvolvimento (PAC) e o Programa Minha Casa Minha Vida (PMCMV), ambos imbricados com políticas anticíclicas de desenvolvimento econômico.

Para melhor compreensão, necessário se faz, a seguir, descrever os antecedentes do PMCMV, tocando num ponto crucial: a conjuntura política em que se 
sedimentou esse Programa, como ele foi pensado e implementado ao fim da gestão do Governo Lula.

Menciona-se, de saída, a criação do Ministério das Cidades, que representou a possibilidade de uma política urbana articulada em variados níveis, além da definição de uma política nacional de desenvolvimento urbano em consonância com as diversas esferas do Estado. De modo inclusivo, assinalava a possibilidade da constituição de uma política urbana mais participativa e efetivamente plural. Pela primeira vez no panorama brasileiro foram realizadas as conferências nacionais das cidades, aprovando diretrizes para a constituição da Política Nacional de Desenvolvimento Urbano, demarcando a criação de um Conselho das Cidades.

Bonduki (2009), conquanto reconheça avanços, ainda, assim, aponta fragilidades na estrutura organizacional do Ministério das Cidades, exprimindo a opinião de que

[...] é necessário ressaltar que uma das debilidades é sua fraqueza institucional, uma vez que a Caixa Econômica Federal, agente operador e principal agente financeiro dos recursos FGTS, é subordinada ao Ministério da Fazenda. Em tese, o Ministério das Cidades é o responsável pela gestão da política habitacional, mas, na prática, a enorme capilaridade e poder da Caixa (...) acaba fazendo com que a decisão sobre a aprovação dos pedidos de financiamento e acompanhamento dos empreendimentos seja de sua responsabilidade. (P. 97).

Essa estrutura limitava, portanto, as condições para se produzir a nova Política Nacional de Habitação (PNH) que incorporava o Projeto Moradia ${ }^{13}$, o qual, em sua proposta, trazia concepções de direito à moradia digna como vetor de inclusão social e de função social da propriedade, buscando implementar instrumentos de reforma urbana, gestão democrática e participação de vários setores da sociedade.

Essa nova política de habitação concentrou-se no Plano Nacional de Habitação (PlanHab) que, durante mais de dois anos, foi elaborado pela Secretaria Nacional de Habitação (SNH) do Ministério das Cidades, ancorados em consultas à sociedade civil, aos estados e aos municípios por meio da Conferência Nacional das Cidades. Essa

\footnotetext{
${ }^{13}$ A proposta fazia parte de um conjunto de iniciativas do Instituto Cidadania, coordenado por Luiz Inácio Lula da Silva. Lançado em 2000, o projeto tinha três dimensões: gestão e controle social; projeto financeiro e urbano fundiário; e enfrentamento da questão não apenas no âmbito do Governo Federal, mas considerando o conjunto dos agentes que têm alguma responsabilidade no problema da habitação, público e privado. Foi desse arcabouço que as ideias do Plano Nacional de Habitação (PlanHab) foram fomentadas.
} 
elaboração propiciou acúmulo de dados e informações importantes, indicando um momento de capacitação do SNH. Conforme aponta a SNH, na ocasião de seu lançamento, o PlanHab representou a retomada do planejamento do setor habitacional no Brasil, ao estabelecer "estratégias de longo prazo para solucionar as necessidades habitacionais do país, presentes e futuras, universalizando o acesso à moradia digna para todo cidadão brasileiro". (PlanHab, 2012, p. 5).

Consoante informam Loureiro, Macário e Guerra (2013), as políticas propostas pelo PlanHab procuraram superar a tradição da produção estatal de moradia. Buscaram diferenciar dos antigos modelos do BNH e das companhias de habitação popular (COHABs); assim como, evitar erros cometidos em outras experiências, como a do México, que criou subsídios habitacionais para a população de baixa renda, sem, entretanto, viabilizar infraestrutura urbana, o que resultou em construção habitacional desconectada de projetos urbanísticos de transporte e serviços de educação e saúde.

A nova política, ao mesmo tempo em que buscava conciliar os dois pensamentos pelo caminho da universalização dos direitos à moradia pelo mercado, aproximava-se de uma visão bancária da Caixa Econômica Federal, que passou a ser o grande órgão concentrador e operacionalizador dos recursos federais.

A tese que orientou o novo modelo, citada no Projeto Moradia, constatava que, no Brasil, o mercado privado oferece um produto habitacional focado em apenas $30 \%$ da população. Por esse motivo, principalmente, a classe média se apropriava dos recursos públicos para esses fins, enquanto as camadas de menor renda, sem condições de competir com esses financiamentos, continuavam à margem da aquisição de moradia própria, conforme sinaliza o gráfico a seguir. 
Gráfico 01: Pirâmide de renda e abrangência do mercado formal de moradia.

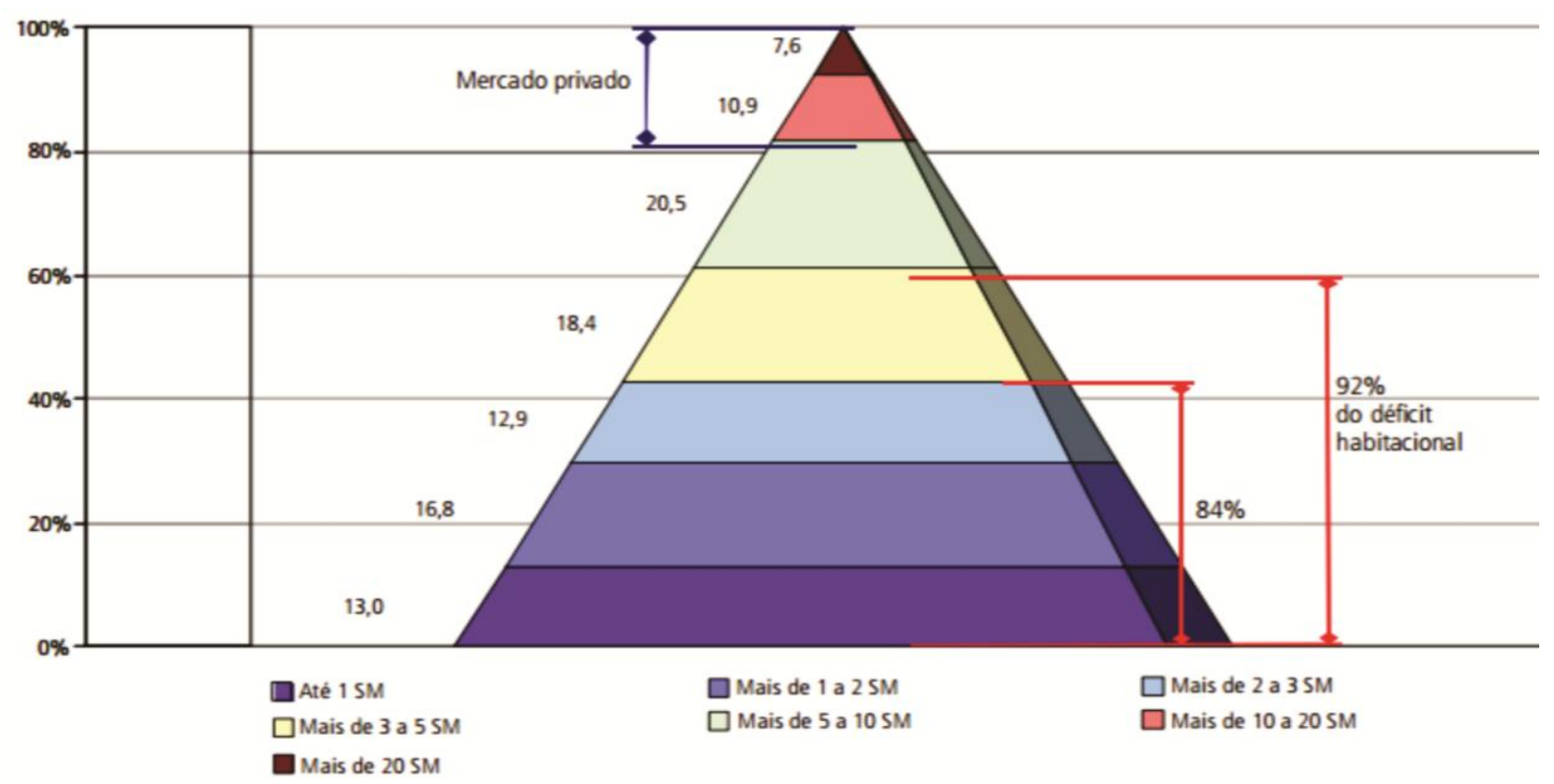

Fonte: Renda e Défice Habitacional: Fundação João Pinheiro, 2000/ Mercado Residencial privado: Projeto de Moradia 2001. Gráfico: IPEA - Acompanhamento de Políticas Sociais/2006.

Compondo o PNH, foram instituídos o Fundo Nacional de Habitação (FNH) e o Sistema Nacional de Habitação de Interesse Social (SNHIS), que, aprovados pela Lei 11.124/2005, exigiam que os municípios criassem estrutura institucional própria, com plano, fundo e conselho de habitação.

Como exprime Maricato (2006), essas exigências davam suporte ao PNH para agir em três principais eixos: política fundiária e financeira e estrutura institucional. Os aspectos relacionados à construção civil seriam tocados na medida em que se tornariam dependentes dessa matriz determinante. O desenho político desse sistema, além de inovar, tendo sua gestão centralizada no Ministério das Cidades, possuía dois subsistemas focados em faixas de renda. Essa medida segregava as fontes de recursos e financiamentos de acordo com as demandas habitacionais.

O PNH também constituiu dois subsistemas: o Subsistema de Habitação de Interesse Social e o Subsistema de Habitação de Mercado. O primeiro destinava-se 
exclusivamente à faixa de até cinco salários-mínimos. Assegurando recursos e subsídios, o Ministério da Cidade geria um panorama habitacional com fontes diferenciadas para cada programa específico de habitação. Do FGTS, seriam reservados a financiamentos em longo prazo, com menores juros que possibilitassem seu equilíbrio. Do FAR, FAT e FDS, destinados à cobertura dos programas, dependeria da demanda; e os demais recursos não onerosos, repassados aos agentes públicos, estaduais e municipais.

O segundo subsistema procurava articular-se com o mercado privado habitacional, reorganizando o setor para que houvesse maior possibilidade de ampliar e de incluir os agentes privados na produção de moradias para rendas médias.

Quando inaugurado o Ministério das Cidades, mantiveram-se os programas do Governo $\mathrm{FHC}^{14}$ em um continuísmo já destacado. Só após 2005, porém, foi que o Fundo Nacional de Habitação de Interesse Social (FNHIS), fundo contábil com destinação específica, movimentou novos programas criados fundamentalmente para focar a faixa de renda de até três salários-mínimos, segmento que concentrou historicamente o défice habitacional.

Na perspectiva de Bonduki (2009), com um quadro já estabilizado e favorável da economia, foi possível recuperar fundos de investimentos para a criação do FNHIS, que injetou significativa quantidade de recursos, no período de 2002 a 2008, no setor habitacional. Essa massiva recuperação de recursos públicos foi destinada para a habitação, ensejando um grande incremento no setor habitacional. ${ }^{15}$ Houve uma elevação de $\mathrm{R} \$ 2,2$ bilhões para $\mathrm{R} \$ \mathbf{2 7}$ bilhões de investimentos por meio da linha de crédito imobiliário com recursos do Sistema Brasileiro de Poupança e Empréstimo (SBPE). Tudo isso ocorreu no momento imediatamente anterior ao lançamento do PMCMV, que passou a ser efetivado em 2009, dando continuidade e acentuando o investimento nesse setor. No gráfico exposto abaixo, pode-se perceber com clareza a evolução desses investimentos.

\footnotetext{
${ }^{14}$ O PAR - Programa de Arrendamento Residencial, o Habitar Brasil/BID, o Pró-Moradia, o PSH e o Programa de Apoio a Produção, alguns reformulados, mas em sua essência preservavam as origens. Sobre o tema, ver tese de Ana Cristina Araújo "Programa Minha Casa Minha Vida: antigos e novos dilemas da habitação social".

${ }^{15}$ Em 2003, foi criado o primeiro programa habitacional do Governo Lula "Crédito Solidário", que tinha como fonte de financiamento os recursos do Fundo de Desenvolvimento Social (FDS).
} 
Gráfico 02: Evolução do SBPE e FGTS

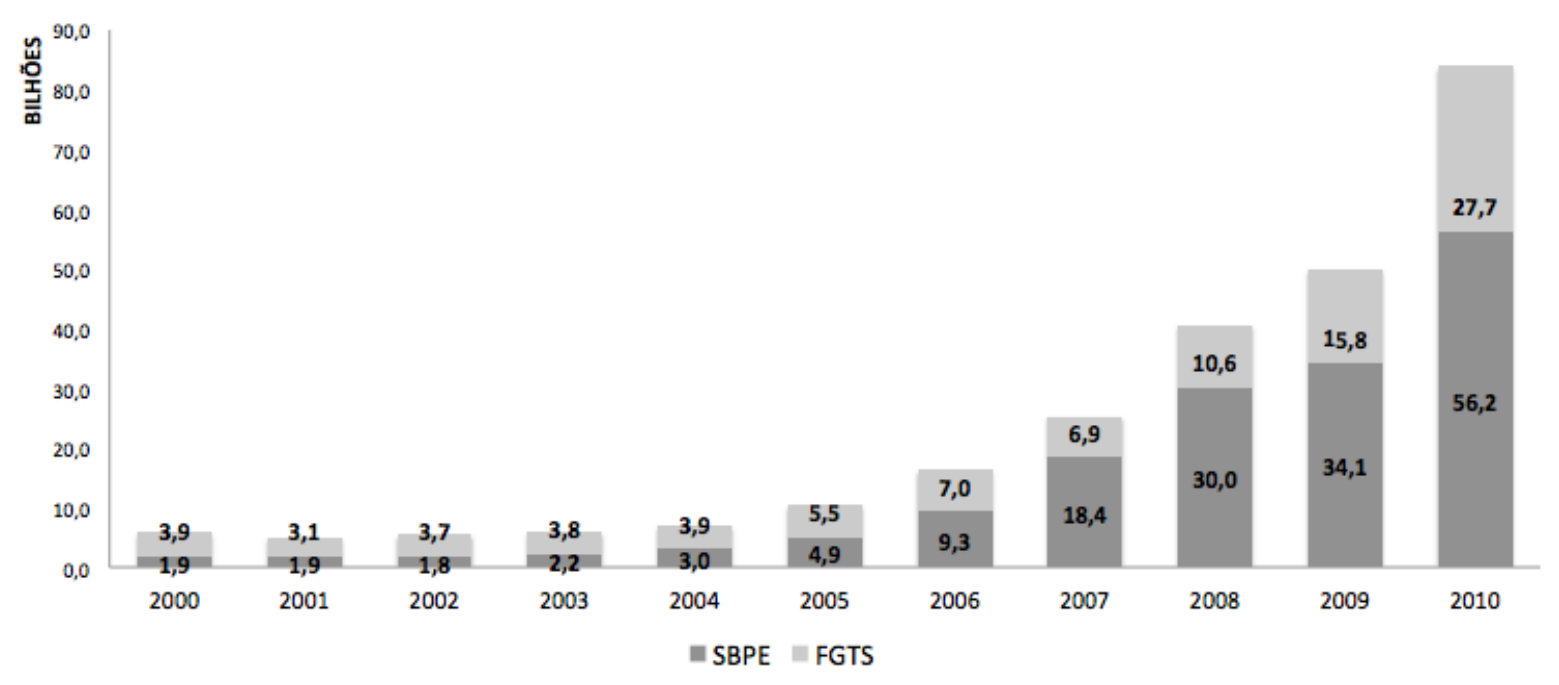

Fonte: Organizado pelo CBIC- dados. (SFH- SBPE/FGTS).

Gráfico: Rufino (2012), editados pela autora.

Esses acréscimos se acentuaram com o lançamento do Programa de Aceleração do Crescimento (PAC), em 2007, que, em sua composição, declara a intenção de combater efeitos de uma possível crise internacional. Reafirmava o valor anticíclico da construção civil para a economia nacional, contudo, seu objetivo maior foi implantar grandes obras de infraestrutura. Entre suas implementações, incluíam-se ações do Programa de Urbanização de Assentamentos Precários, programa de caráter social que estabelecia recursos para o setor habitacional, mas, de forma inusitada, a depender das ações já comprometidas e das propostas oferecidas.

A criação do Ministério das Cidades trouxe desenvolvimento quando procurou ampliar os recursos disponíveis para a área da habitação, combinando a utilização do FGTS com mecanismos de subsídios. Loureiro, Macário e Guerra (2013) destacam terem sido realizadas nesse Ministério importantes medidas para a aproximação do setor da construção civil. Em 2004, foi aprovada a Lei do Patrimônio da Afetação, como já citada, que estabelece maior segurança jurídica ao financiamento e à produção 
privada de moradias. Em 2005, foi aprovada a resolução que obriga os bancos a investirem parte de seus recursos captados por meio da poupança em financiamento habitacional. Neste mesmo ano, finalmente, foi promulgada a Lei $\mathrm{n}^{\circ} 11.124$, que estruturou o SNHIS e criou, também, o FNHIS, aprovado em congresso em versão modificada à proposta inicial, uma vez que encontra resistência na abrangência de sua proposta, sendo promulgado de modo mais restrito.

O FNHIS previa que, com a adesão voluntária dos municípios, respeitando alguns princípios mínimos (como a criação de um fundo de habitação municipal, um conselho gestor participativo e a elaboração de um plano), os recursos seriam transferidos diretamente a esses entes federativos, cabendo ao Conselho Monetário Nacional (CMN) a gestão do Fundo. Outra medida importante foi editar a Resolução $\mathrm{n}^{\circ} 460 / 2005^{16}$, pelo Conselho Curador do FGTS, que ampliou os recursos disponíveis deste para subsídios habitacionais, aumentando o atendimento na faixa de renda mais baixa.

Como reforça Fix (2011), as medidas jurídicas para incentivar a produção habitacional dos segmentos mais populares, centradas na Lei 10.931/2004 do Patrimônio da Afetação ${ }^{17}$ e associadas às exigências do Banco Central de utilização da poupança para o financiamento habitacional por parte dos bancos, encontraram nas políticas públicas e no quadro econômico do Brasil uma situação favorável para um grande "boom imobiliário".

Com a retomada dos investimentos e a ampla possibilidade de crescimento de 2002 a 2008, empresas da construção civil efetivaram abertura de capital. Vinte e quatro empresas abriram ação no Bovespa. E, ante a necessidade de ampliar mercado, organizações do setor imobiliário, que tradicionalmente atuavam nos setores de alta renda, criaram subsidiárias especializadas em produtos "econômicos" dirigidos à classe média, segmento que mais cresceu com as políticas distributivas do Governo Lula.

Abaixo, uma pesquisa de Tavares (2008) lista as empresas incorporadoras de empreendimentos imobiliários que abriram ações na Bolsa de Valores de 2005 a 2007. Os valores lançados aparecem em duas colunas. A primeira diz respeito à oferta

\footnotetext{
16 Resolução CC/FGTS no 460 de 14/12/2004 estabelece diretrizes para a aplicação dos recursos e a elaboração das propostas orçamentárias do FGTS, no período de 2005 a 2008.

17 Essa lei representou 'um marco na história do mercado imobiliário', ao unir o mercado imobiliário, financeiro e de capitais, segundo documento redigido pela Câmara Brasileira da Indústria da Construção.
} 
primária que se traduz nos lançamentos, por uma empresa, de novas ações no mercado, e, a segunda, se refere às ofertas secundárias.

Quadro 02: Empresas Incorporadoras que abriram ações na Bolsa de Valores

\begin{tabular}{|c|c|c|c|c|}
\hline EMPRESA & $\begin{array}{c}\text { DATA DE } \\
\text { INÍCIO DA } \\
\text { NEGOCIAÇÃO }\end{array}$ & $\begin{array}{c}\text { VALOR } \\
\text { LANÇADO } \\
\text { (R\$ MIL) } \\
\text { OFERTA } \\
\text { PRIMÁRIA }\end{array}$ & $\begin{array}{c}\text { VALOR } \\
\text { LANÇADO } \\
\text { (R\$ MIL) } \\
\text { OFERTA } \\
\text { SECUNDÁRIA }\end{array}$ & $\begin{array}{c}\text { PARTICIPAÇÃO } \\
\text { DE INVESTIDOR } \\
\text { ESTRANGEIRO } \\
(*)\end{array}$ \\
\hline Brascan Residencial Properties S.A. & $20-10-2006$ & 940.000 & 248.000 & 87,4 \\
\hline $\begin{array}{l}\text { Camargo Corrêa Desenvolvimento } \\
\text { Imobiliário }\end{array}$ & $30-01-2007$ & 478.500 & 43.500 & 55,6 \\
\hline Company S.A. & $01-03-2006$ & 208.000 & 73.600 & 63,6 \\
\hline \multirow{2}{*}{$\begin{array}{l}\text { Cyrela Brazil Ralty S.A. } \\
\text { Empreendimentos e Participaçóes }\end{array}$} & $01-07-2005$ & 511.000 & 391.200 & 25,6 \\
\hline & $20-07-1996$ & 728.700 & 109.200 & 75,5 \\
\hline Even Construtora e Incor, S.A. & $30-03-2007$ & 460.000 & 0 & 52,5 \\
\hline \multirow{2}{*}{ Gafisa S. A. } & $16-02-2006$ & 494.400 & 432.600 & 72,2 \\
\hline & $19-03-2007$ & 487.812 & 683.493 & 66,9 \\
\hline Klabin Segall S. A. & $06-10-2006$ & 375.500 & 181.700 & 65,1 \\
\hline P D G Realty & $25-01-2007$ & 420.000 & 228.395 & 93,4 \\
\hline Rodobens Negócios Imobiliários & $30-01-2007$ & 390.000 & 0 & 67 \\
\hline Rossi Residencial S.A. & $14-02-2006$ & 612.500 & 250.000 & 80,3 \\
\hline Tecnisa & $31-01-2007$ & 590.652 & 200.651 & 60,8 \\
\hline Total & & 6.697 .064 & 2.842 .339 & \\
\hline
\end{tabular}

Fonte: BOVESPA, 2007, APUD: TAVARES (2008, P. 58).

O quadro exposto acima indica ainda um grande volume negociado, chegando perto de dez trilhões de reais, cerca de cinco trilhões e meio de dólares. Também apontam para a grande participação de investidores estrangeiros. Em um movimento gestado pelas empresas do setor imobiliário, há dinâmicas para expandir e centralizar o capital. Associam-se a tal estratégia de financeirização as investidas em captação de recursos para financiamento imobiliário.

A tese de Shimbo (2010) esclarece que, desde os anos de 1990, era constituído um campo favorável para a provisão privada de habitação. Com todos os instrumentos jurídicos de securitização de créditos já formatados por meio das medidas regulatórias e do aumento de recursos destinados ao financiamento habitacional, o lançamento do PMCMV não poderia ser encarado como uma grande surpresa. 
Com a economia em pleno crescimento no Governo Lula, o Estado ainda poderia adotar políticas de incentivo à ampliação dos recursos do FGTS. Tão logo recuperados e ampliados esses recursos, foram acordadas medidas que assegurassem a estabilidade financeira desse Fundo. Em 2004, foi aprovada a medida provisória conhecida como "MP do bem", que permitia a isenção de impostos na alienação de imóveis quando houvesse emprego de recursos na aquisição de outros imóveis residenciais.

É importante destacar o fato de que, no momento da formulação da política habitacional, a Casa Civil passa a desempenhar papel de destaque. Antes mesmo do lançamento oficial do PMCMV, em março de 2009, a então ministra Dilma Rousseff realizava reuniões com grupo de empresários do setor da construção civil, inicialmente formados por Cyrela, Gafisa, Rossi, MRV, PDG, Odebrechet, WTorre e Rodobens, para discutir o tema e já se falava na construção de um milhão de casas para a faixa de renda até dez salários mínimos, incluindo a estruturação do fundo garantidor.

Assim, um novo programa habitacional a ser priorizado pelo Governo era visto de maneira favorável pelo empresariado da construção civil que nele encontraria meios de escoar as unidades já em produção e garantir o retorno aos investimentos. Ao lado do Governo, o setor da construção civil teria importante papel na dinamização da economia e na geração de emprego, dando ao PMCMV objetivos diversos, uma vez que atuava ante ao grande défice habitacional nacional e, também, como resposta aos efeitos da crise internacional, à medida que provê empregos no setor da construção civil e aquece a economia por meio da grande cadeia produtiva da construção.

Foi nesse âmbito de pleno desenvolvimento do setor imobiliário e funcionamento da política de crédito, no ano de 2009, que foi lançado o Programa Minha Casa Minha Vida, ainda que contrário aos debates realizados nas conferências realizadas no Ministério das Cidades, em que se pensavam a consolidação do Sistema Nacional de Habitação de Interesse Social e as diretrizes do Plano Nacional de Habitação - PlanHab.

Bonduki (2009) realça o argumento de que, apesar de o PlanHab ter disponibilizado opções habitacionais a custos reduzidos - como oferta de lotes urbanizados, soluções por assistência técnica e apoio à aquisição de materiais de construção - o PMCMV concentrou-se na produção de mais unidades em que o 
desenho de sua política pública estava em consonância com as expectativas do setor da construção civil.

Os rumos que a política habitacional representa no deslocamento das prioridades antes acordadas com o Ministério das Cidades para as imposições determinadas tanto pela necessidade de uma resposta a uma possível crise econômica quanto pela pressão do empresariado que cada vez mais se aproximava da Casa Civil, parecem ganhar mais e mais espaço dentro da política habitacional na iminência do lançamento do PMCMV.

O Programa, na época do lançamento, fora expresso como resposta à crise financeira que surpreendeu o Mundo em 2008. O PMCMV justificava-se como medida anticíclica, articulando medidas e recursos para acelerar e promover a produção de mais unidades habitacionais, tendo o propósito de desenvolver a construção civil e o mercado imobiliário. Alguns autores, a exemplo de Amorim (2012), que estudam o lançamento do PMCMV desde a perspectiva do entendimento da atuação do mercado imobiliário, identificam o fato de que o Programa se harmoniza aos interesses do setor imobiliário, uma vez que assegura menores riscos e é mais atraente para investidores.

A construção civil, como setor que mais possui efeitos multiplicadores de investimentos, foi o meio escolhido para aquecer a economia. A "urgência" em ativar o setor foi combinada com a ameaça enfrentada pelas empresas da construção civil com capitais na Bolsa de Valores que precisavam de medidas macroeconômicas para retificar a credibilidade de seus papeis. (AMORIM, 2012, p.32).

Para viabilizar o Programa aos vários segmentos que se pretendiam atender, cria-se uma estrutura sob a forma de um conjunto de modalidades que compõem o seu todo; ou seja, o PMCMV funciona como grande "pacote" que reúne diversas modalidades de programas habitacionais encabeçados pelo Governo Federal, os quais, apesar de compartilharem do mesmo objetivo de fomentar a habitação no Brasil, possuem características particulares.

Todos os programas habitacionais que estavam sendo produzidos, em vias de serem entregues, migravam para o PMCMV, sejam eles Programa de Arrendamento Residencial, Programa Carta de Crédito, ou qualquer outro. Toda a política habitacional pareceu se transformar em um megaprograma - o PMCMV. 
Compreendendo o histórico recente das principais mudanças no arcabouço institucional para a implementação do PMCMV, passa-se, agora, a introduzi-lo, tentando uma vez mais entender a conjuntura em que ele é criado. Aqui, a justificativa de medida anticíclica e a regulação da economia pelo incremento da construção civil se repetem. O detalhamento do Programa, contudo, permite avançar nessa discussão.

\subsection{O Programa Minha Casa Minha Vida}

Se, anteriormente, o esforço foi para entender os processos que culminaram no desenvolvimento do atual desenho da política habitacional, em que interesses de diferentes agentes políticos influenciaram na definição de um desenho institucional da política habitacional efetivamente inaugurada em março de 2009, com o PMCMV, passou-se, então, a buscar compreender o contexto político e dos arranjos institucionais que legitimaram esse Programa e que se concretizaram em legislações e quadros políticos e operacionais definidos, estabelecendo as bases das negociações dos agentes envolvidos na gestão e desenvolvimento da política habitacional.

Neste item, busca-se entender o desenho institucional do PMCMV desde o seu lançamento, em 2009. Com suporte de um quadro de legislação que compõe o Programa, serão mostrados os investimentos realizados e sua articulação com fontes de recursos. Em seguida, preparar-se uma pequena introdução para compreender o arcabouço institucional que se iniciou na esfera federal e se articulou com aos diferentes níveis e esferas do Governo.

O PMCMV propôs uma estratégia de atuação e um desenho em que as distintas prefeituras e agentes imobiliários locais irão se relacionar entre si, momento importante para compreender se de fato há uma omissão de um Estado regulador ou o que se discute é a concessão das decisões para a lógica privada.

\subsubsection{A conjuntura da criação do marco legal para o PMCMV}

Conforme visto no início deste capítulo, foi no Governo Lula, depois do primeiro momento de estabilização da economia, que ocorreu uma retomada nos investimentos em habitação. Cunha (2014) menciona que o PMCMV deve ser 
entendido conjunturalmente. Não foi mera evolução do sistema habitacional advindo do BHN ou um projeto do Governo Lula traçado antes de sua chegada ao poder. Tampouco o caso pode ser entendido como um desenvolvimento do PlanHab. Afinal, como visto, o Programa retrata o enfraquecimento deste último.

Desde a sua primeira medida provisória, MP N. 459/2009, quando foi instituída a Lei N. 11.977 que cria o Programa Minha Casa Minha Vida, em julho de 2009, o Programa operacionaliza e setoriza investimentos do Programa de Aceleração de Crescimento (PAC), intimamente atrelado ao PMCMV. A principal justificativa para o lançamento deste Programa foi mobilizar o setor da construção civil por meio de incentivos à produção como uma estratégia anticrise, como já levantado no início deste capítulo. Para isso, se estabeleceu a meta de um milhão de moradias distribuídas entre faixas salariais, que foi ampliada para dois milhões de unidades habitacionais na segunda fase do Programa, dando continuidade à estratégia de produzir moradias distribuídas por faixas de renda.

É importante destacar o fato de que o PMCMV setoriza a produção em faixas de renda, definindo, desde o seu início, três divisões: 0-3 salários mínimos (faixa 1), acima de 3 até 6 salários mínimos (faixa 2) e acima de 6 até 10 salários mínimos (faixa 3). Cada uma tem recursos próprios e especificidades como se tratará no decorrer a seguir.

$\mathrm{Na}$ interlocução de Cunha (2014), mesmo em termos financeiros, o PMCMV ignorou algumas diretrizes importantes estabelecidas no Governo Lula. No desenho do Programa, a função concentradora de recursos para as menores faixas de renda, de 0-3 salários mínimos, foi destinada ao Fundo de Arrendamento Residencial (FAR), um fundo público secundário que, por isso, era mais maleável e desregulado. O modelo de oferta privada do FAR tornou dispensáveis projetos e licitações públicas, o que permitia às grandes construtoras e incorporadoras a definição do local e da tipologia do projeto, enquanto aos municípios cabiam prover a demanda.

Nas faixas 2 e 3, os recursos advinham do FGTS e beneficiavam, inicialmente, subsídios diretos de até 20 mil reais, mais a redução nos juros conforme os rendimentos familiares. A comercialização era feita diretamente pelas empresas nos estandes de vendas montados por elas ou nos muitos "feirões da casa própria" que 
aconteceram ao longo de todos esses anos patrocinados pela Caixa Econômica Federal.

É importante saber que o PMCMV não foi a única medida anticrise planejada no plano federal, contudo, foi a que prevaleceu ante o conjunto de forças políticas e possibilidades que pressionavam o Governo. O modelo institucional deste Programa é, portanto, resultado de caráter conjuntural.

Como mencionado no item imediatamente anterior, depois do lançamento de um programa, houve intensa modificação no setor da construção civil. A corrida para a abertura de capitais e a ampliação do mercado de terras aconteceu antes da primeira medida provisória ser lançada em um processo que favoreceu, desde os anos 1990, a ampliação do mercado da construção civil para os estratos mais populares.

Cunha (2014), uma vez mais, destaca que o PMCMV selecionou um conjunto de experiências de políticas habitacionais desde o Governo do FHC, aquelas que tinham princípios gerais que favorecessem o modelo da iniciativa privada, além de misturar a essas experiências o "modelo de negócio" flexível contido no Programa de Arrendamento Residencial ${ }^{18}$. Adotou-se o crédito direto aos consumidores ou às entidades que pertenciam a outras modalidades, ou seja, ao Programa de Carta de Crédito Individual e à Carta de Crédito Associativo, respectivamente. Esse modelo excluía definitivamente a promoção estatal e se baseava em projetos e licitações comandados por órgãos públicos com fundos menores e, muitas vezes, com maior concorrência para as demandas oferecidas.

Como relata Fix (2011), o Governo Federal chegou a propor antes da Medida Provisória N. $443^{19}$ que a Caixa Econômica Federal comprasse ações de empresas da construção civil - um modelo híbrido público privado, em que o Estado entraria com outra participação além dos subsídios. Obviamente, essa proposta foi tolhida, pois o forte setor imobiliário se organizou e se opôs. Ao que parece, não seria do interesse

\footnotetext{
${ }^{18}$ O Programa de Arrendamento Residencial (PAR) também foi criado pelo Ministério das Cidades e executado pela CAIXA, antecedendo o PMCMV. Entre os anos de 2003 e 2006, praticamente, o PAR concentrou os recursos de financiamento em sua execução, tanto o FGTS quanto as cartas de crédito associativo e individual. Para mais informações, consultar tese de doutorado: Programa Minha Casa Minha Vida: antigos e novos dilemas da habitação de interesse social e o caso de Marília- SP (ARAúJO, 2013).

${ }^{19}$ A Medida Provisória N.443 foi aprovada em outubro de 2008 justamente para autorizar o Banco do Brasil e a Caixa Econômica Federal a constituírem subsidiárias e a adquirirem participação em instituições financeiras sediadas no Brasil, além de dar outras providências, como a possibilidade de contratar empresas avaliadoras especializadas.
} 
dos empresários uma intervenção do Estado tão direta. Ao segmento estatal, como será visto, coube apenas o apoio para produzir habitação de baixo custo, em especial, subsídios e recursos orçamentários que alimentariam o sistema financeiro necessário para esse tipo de produção.

Todas essas definições fazem do PMCMV um ato fundador, conforme Arantes (2010), uma vez que contribuiu para amarrar as soluções privadas conquistadas ao longo dos anos. Essa forma de amarrar de uma vez por todas as soluções privadas junto à questão habitacional - a conquista de um aumento de $30 \%$ na tabela de valores pagos por unidade habitacional em relação aos valores pagos no programa em vigência anterior, O PAR -, demonstra como a política estava interessada em resolver a baixa rentabilidade das operações desse Programa, e, dessa forma, ampliar a participação dos grandes grupos do mercado imobiliário e do setor da construção civil.

\subsubsection{A definição do desenho Institucional do PMCMV e sua estrutura financeira}

Conforme descrito na Medida Provisória N. 459/2009, do ponto de vista econômico, o PMCMV foi inicialmente alimentado com recursos do Fundo de Arrendamento Residencial (FAR), do Fundo de Desenvolvimento Social (FDS), do Fundo Garantidor da Habitação Popular (FGHab) e do Banco Nacional de Desenvolvimento Econômico e Social (BNDES), cada um somando aportes descritos no quadro abaixo.

Quadro 03: Fundos financeiros estruturantes do PMCMV I.

\begin{tabular}{|l|c|}
\hline \multicolumn{1}{|c|}{ FUNDO } & APORTES FINANCEIROS (em Reais) \\
\hline FAR & $\mathrm{R} \$ 15.500 .000 .000,00$ (quinze bilhões e meio de reais) \\
FDS & $\mathrm{R} \$ 500.000 .000,00$ (quinhentos milhões de reais) \\
$\begin{array}{l}\text { FGTS } \\
\text { FGHab }\end{array}$ & Até R\$ 2.000.000.000,00 (dois bilhões de reais) \\
BNDES & $\mathrm{R} \$ 5.000 .000 .000,00$ (cinco bilhões de reais) \\
\hline
\end{tabular}

Fonte: Dados do Ministério das Cidades.

Com o total de 23 bilhões de reais, o PMCMV inaugurava a primeira fase e distribuía os recursos que, somados ao da União tinham a ordem de 34 bilhões de reais. Com relação ao Fundo de Garantia do Tempo de Serviço (FGTS), como sua 
alocação é regulada plurianualmente, os valores despendidos junto ao PMCMV variaram e não constam no quadro legislativo do Programa.

Esses recursos se destinam a dois subprogramas: Programa Nacional de Habitação Urbana (PNHU) e Programa Nacional de Habitação Rural (PNHR). O primeiro designa-se a produção ou aquisição de unidades novas em áreas urbanas e qualificação de imóveis em áreas consolidadas. Seu subsídio concentra o montante de dois bilhões e quinhentos milhões de reais. O segundo atende a agricultores e trabalhadores rurais e é separado pela renda bruta familiar anual, que é dividida em três grupos: grupo 1 - com renda até $\mathrm{R} \$ 10$ mil; grupo 2 - com renda até 22 mil; e grupo 3 - com renda familiar até 60 mil.

Existe ainda outra divisão no PMCMV, respeitante à instituição contratante do financiamento: modalidade Entidades e Empresas. A primeira destina-se a beneficiários organizados associativamente por meio de uma entidade organizadora (EO), e se caracteriza, em teoria, como uma linha de financiamento sem fins lucrativos. Os principais agentes do PMCMV Entidades seriam o Ministério das Cidades, Caixa Econômica Federal, a entidade organizadora (EO) e o responsável técnico ou assessoria Técnica (AT). A diferença entre estes dois últimos está em que a entidade (EO) é o ente jurídico responsável por organizar, reunir e apoiar as famílias no desenvolvimento das distintas etapas da proposta de intervenção habitacional, com as cooperativas, associações e demais entidades da sociedade civil. O responsável técnico ou AT é o profissional, ou empresa, indicado pela entidade para realizar projetos de arquitetura, trabalho social, engenharia, bem como organizar as execuções.

Já a segunda modalidade, Empresas, tem seus recursos provenientes do Orçamento Geral da União (OGU) e alocados ao Fundo de Arrendamento Residencial (FAR). É aqui onde se concentra a grande atuação do PMCMV, que incide na constituição de linha de financiamentos com fins lucrativos. Os agentes participantes do PMCMV Empresas são: o Ministério das Cidades, o Ministério da Fazenda e do Planejamento, Orçamento e Gestão, a Caixa Econômica Federal, o Distrito Federal, além de estados e municípios e empresas do setor da construção civil.

Nesta última modalidade, os recursos do FGTS são linhas de crédito para três submodalidades: 1) Imóvel na planta - linha de crédito para produção de empreendimentos habitacionais com financiamento direto às pessoas físicas; 2) Apoio 
à produção - financiamento direto às pessoas jurídicas, construtoras, incorporadoras e sociedades de propósitos específicos para a produção de empreendimentos habitacionais; 3) Alocação de recursos - linha de crédito destinada às empresas que constroem com recursos próprios ou de terceiros, garantindo o financiamento direto às pessoas físicas.

A segmentação de renda é uma característica do PMCMV, e a fonte de recursos varia conforme essa condição. Assim, caso a solicitação do recurso seja acionada por uma empresa do setor da construção civil, para uma família que recebe até 3 salários mínimos, o PNHU indica o FAR. Se o financiamento for para essa mesma faixa de renda, embora a solicitação seja feita por entidades e associações comunitárias, a fonte será o FDS. O recurso destinado a atender as demais faixas é concentrado nos financiamentos do FGTS e acesso ao Fundo Garantidor da Habitação (FGHab), conforme é mais bem esclarecido no quadro a seguir:

Quadro 04: Subprogramas, linhas, fontes de recursos e metas

\begin{tabular}{|c|c|c|c|}
\hline \multicolumn{4}{|c|}{ PMCMV-1 - Maio de 2009 a maio de 2011} \\
\hline $\begin{array}{c}\text { Sub- } \\
\text { Programa }\end{array}$ & Linha & Fonte & Meta (unidades) \\
\hline PNHR & Grupo 1 (G-1): Renda até R\$̣ $15 \mathrm{mil} / \mathrm{ano}$ & OGU & \multirow{3}{*}{400.000 - Faixa $1(40 \%)$} \\
\hline \multirow{3}{*}{ PNHUR } & Empresas & FAR & \\
\hline & Entidades & FDS & \\
\hline & Financiamento Habitacional & FGTS & \multirow{3}{*}{$\begin{array}{l}400.000-\text { Faixa } 2(40 \%) \\
200.000 \text { - Faixa } 3(20 \%)\end{array}$} \\
\hline \multirow{2}{*}{ PNHR } & $\begin{array}{l}\text { Grupo } 2 \text { (G-II) - Renda entre R\$ } 15 \text { e R\$ } \\
\text { 30 mil/ano }\end{array}$ & FGTS & \\
\hline & $\begin{array}{l}\text { Grupo } 3 \text { (G-III) - Renda entre } R \$ 30 \text { mil } \\
\text { e } R \$ 60 \text { mil/ano }\end{array}$ & FGTS & \\
\hline \multicolumn{4}{|c|}{\begin{tabular}{lr|l} 
& Total & 1 \\
\end{tabular}} \\
\hline \multicolumn{4}{|c|}{ PMCMV-2 - Junho de 2011 a dezembro de 2014} \\
\hline $\begin{array}{c}\text { Sub- } \\
\text { Programa }\end{array}$ & Linha & Fonte & Meta (unidades) \\
\hline \multirow{4}{*}{ PNHUR } & Empresas & FAR & 860.000 - Faixa 1 (43\%) \\
\hline & Entidades & FDS & $60.000-$ Faixa $1(3 \%)$ \\
\hline & Oferta pública & $\begin{array}{l}\text { Instituições } \\
\text { ou agentes } \\
\text { financeiros } \\
\text { autorizados }\end{array}$ & $220.000-$ Faixa $1(11 \%)$ \\
\hline & Financiamento Habitacional & FGTS & $\begin{array}{l}600.000-\text { Faixa } 2(30 \%) \\
200.000-\text { Faixa } 3(10 \%)\end{array}$ \\
\hline \multirow{3}{*}{ PNHR } & Grupo 1 (G-1) - Renda até R\$ $15 \mathrm{mil} / \mathrm{ano}$ & OGU & \multirow{3}{*}{$60.000^{64}(3 \%)$} \\
\hline & $\begin{array}{l}\text { Grupo 2 (G-II) - Renda entre R\$ } 15 \text { e R\$ } \\
\text { 30 mil/ano }\end{array}$ & FGTS & \\
\hline & $\begin{array}{l}\text { Grupo } 3 \text { (G-III) - Renda entre } R \$ 30 \text { mil } \\
\text { e } R \$ 60 \text { mil/ano }\end{array}$ & FGTS & \\
\hline & & Total & $2.000 .000^{65}(100 \%)$ \\
\hline
\end{tabular}

Fonte: Dados da Caixa Econômica Federal e do Governo Federal.

Organização de Cunha (2014). 
Este quadro representa as metas da primeira fase do PMVMC. Com mudanças significativas na legislação em 2011, os fundos passaram a se articular distintamente com os financiamentos. É importante destacar, logo de início, o fato de que as metas estabelecidas já foram atingidas em janeiro de 2013, isso em termos gerais, pois as metas da modalidade Entidades, não foram alcançadas. O Programa, em sua segunda fase, parece formalizar a edição da Medida Provisória 514/2010, convertida na Lei N. 12.424, em 16 de julho de 2011, que estabelecia novas metas e diretrizes ao Programa habitacional, dentre elas a ampliação da de entrega dos recursos do FAR e do FDS para a faixa 1. A meta principal seria o financiamento da construção de dois milhões de unidades residenciais no País até os anos 2014.

Serão auferidas com a devida acuidade as principais mudanças na legislação do PMCMV durante os anos de sua implementação e regulação, assim como vão ser discutidas as repercussões dessas propostas. Cabe, aqui, no entanto, frisar que o número de portarias e adendos realizados ao longo desses anos é grande. Serão expressas, portanto, as mudanças mais significativas.

Há definições no corpo da lei que rege o PMCMV de ordens diversas, tais como: estabelecimento da priorização das unidades habitacionais para os chefes de família, portadores de necessidades especiais, idosos e populações oriundas de áreas de risco; atualização dos valores dos imóveis a serem financiados; estabelecimento de sistemas de avaliação de pós-ocupação e implementação do trabalho técnico social (TTS).

Propõe-se discutir os dispositivos legais mais gerais, aqueles que mudam de fato o andamento do arcabouço do Programa; legislação que claramente modificam o interesse da saída ou entrada dos agentes imobiliários com vistas a interferir na sua lucratividade; as que visivelmente se associam a regulação urbanística, tais como: limitações de números de unidades, necessidade de infraestrutura urbana e questões ligadas diretamente à aprovação de terrenos e escolhas destes mesmos pelos agentes produtores.

\subsubsection{A regulação do PMCMV, análise da legislação e suas diretrizes} urbanísticas 
É importante ressaltar que o PMCMV é um programa habitacional em andamento e passa por constante estruturação, estando no atual momento de conjuntura política marcado pelas incertezas sobre o efetivo lançamento de sua terceira etapa. Tal situação enseja a obtenção de novos dados no decorrer de seu processo, exprimindo desafios para acompanhar sua legislação em contínuo procedimento de mudanças. São ainda destaques deste Programa, suas leis, decretos, medidas provisórias, portarias e resoluções normativas, muitas vezes, estabelecidos por distintos órgãos, o que torna mais complexo o trabalho de seu mapeamento e análise. Por meio do quadro, expresso a seguir, com as principais leis e resoluções normativas, espera-se facilitar o entendimento da regulação do Programa em discussão. Ressalta-se que este quadro parte da tese de Cunha (2014), e, aqui, se prolongam esforços na continuidade e atualização das ementas e leis que seguem a se desdobrar enquanto o Programa se desenvolve.

Quadro 05: Cronologia das principais regulamentações do PMCMV

\begin{tabular}{|c|c|c|}
\hline Classificação e numeração & Data & Conteúdo/Assunto \\
\hline Medida Provisória N. 459 & $25 / 03 / 2009$ & Criação e diretrizes mais gerais do PMCMV. \\
\hline Decreto N. 6.819 & $13 / 04 / 2009$ & Regulamenta a Med. Provisória N. 459. \\
\hline Portaria MCidades N. 139 & 27/04/2009 & $\begin{array}{l}\text { Dispõe sobre a aquisição e a alienação de } \\
\text { imóveis sem prévio arrendamento no âmbito } \\
\text { do PAR. }\end{array}$ \\
\hline Ins. Normativa RFB N. 934 & 28/04/2009 & $\begin{array}{l}\text { Dispõe sobre o regime especial de tributação } \\
\text { das incorporações imobiliárias e sobre o } \\
\text { pagamento unificado de tributos aplicáveis } \\
\text { às construções contratadas no âmbito do } \\
\text { PMCMV. }\end{array}$ \\
\hline Resolução N. 141 & $10 / 06 / 2009$ & $\begin{array}{l}\text { Regulamenta a utilização dos recursos da } \\
\text { União previstos na MP N. } 459 \text { e no Decreto } \\
6.819 \text { e cria o PMCMV- Entidades. }\end{array}$ \\
\hline Lei N. 11.977 & 07/07/2009 & $\begin{array}{l}\text { Cria diretrizes gerais do PMCMV e a } \\
\text { regularização fundiária urbana. }\end{array}$ \\
\hline Instrução Normativa N. 36 & $15 / 07 / 2009$ & $\begin{array}{l}\text { Regulamenta a Resolução N. } 141 \text { que criou } \\
\text { com a utilização dos recursos da União o } \\
\text { PMCMV - Entidades. }\end{array}$ \\
\hline Decreto - 6.962 & 07/07/2009 & $\begin{array}{l}\text { Revoga o Decreto n. } 6.819 \text { e regulamenta a } \\
\text { Medida Provisória n. } 459 \text { (Criação MCMV) }\end{array}$ \\
\hline Instrução Normativa - 57 & $12 / 11 / 2009$ & Altera as intruções da Normativa n.36 \\
\hline
\end{tabular}




\begin{tabular}{|c|c|c|}
\hline Portaria N. 140 & 05/03/2010 & $\begin{array}{l}\text { Dispõe sobre a aquisição e a alienação de } \\
\text { imóveis sem prévio arrendamento no âmbito } \\
\text { do Programa PAR e PMCMV. }\end{array}$ \\
\hline Resolução N. 154 & $24 / 03 / 2010$ & $\begin{array}{l}\text { Altera a Resolução N.141 para definir } \\
\text { condições de financiamento com a Entidade } \\
\text { Organizadora. }\end{array}$ \\
\hline Instrução Normativa N. 28 & 20/05/2010 & Altera as instruções da Normativa N.36. \\
\hline Portaria N. 479 & $29 / 09 / 2010$ & Modifica a redação da Portaria N.93. \\
\hline Medida Provisória N 514 & $16 / 06 / 2011$ & $\begin{array}{l}\text { Altera a Lei } 11.977 \text {, as Leis } 10.188 \text {, de } \\
12 / 02 / 2001,6.015 \text {, de } 31 / 12 / 1973,6.766 \text {, de } \\
\text { 19/12/1979, e } 4.591 \text {, de } 16 / 12 / 1964 \text {. }\end{array}$ \\
\hline Decreto N. 7.499 & $16 / 06 / 2011$ & $\begin{array}{l}\text { Revoga o Decreto N. } 6.962 \text { e regulamenta } \\
\text { dispositivos da Lei N. } 11977 .\end{array}$ \\
\hline Lei N. 12.424 & $16 / 06 / 2010$ & Cria a segunda fase do PMCMV. \\
\hline Resolução N. 182 & $18 / 08 / 2011$ & Regula a segunda fase do PMCMV Entidade. \\
\hline Inst. Normativa N. 34 & $28 / 09 / 2011$ & $\begin{array}{l}\text { Atualiza a Resolução N.182, de 18/08/2011, } \\
\text { quanto a recursos da União e especificações } \\
\text { mínimas das habitações. }\end{array}$ \\
\hline Portaria Interministerial N. 464 & 03/09/2011 & $\begin{array}{l}\text { Dispõe sobre as operações com recursos } \\
\text { transferidos ao FDS, contratadas no âmbito } \\
\text { do PNHU. }\end{array}$ \\
\hline Portaria N. 465 & $30 / 09 / 2011$ & Atualiza e estabelece as diretrizes do FAR. \\
\hline Resolução N. 183 & $10 / 11 / 2011$ & Altera e aprova o PMCMV- Entidades 2. \\
\hline Portaria N. 610 & $26 / 12 / 2011$ & $\begin{array}{l}\text { Dispõe sobre os parâmetros de priorização e } \\
\text { o processo de seleção dos beneficiados do } \\
\text { PMCMV. }\end{array}$ \\
\hline Portaria Interministerial N. 229 & 03/09/2011 & $\begin{array}{l}\text { Dispõe sobre o Programa Nacional de } \\
\text { Habitação Rural - PNHR. }\end{array}$ \\
\hline Resolução N. 238 & $06 / 06 / 2012$ & $\begin{array}{l}\text { Altera o texto dos Anexos I, II e IV da Port. N. } \\
465 .\end{array}$ \\
\hline Resolução N. 300 & 05/07/2012 & Dá nova redação à Portaria N. 465 \\
\hline Portaria N. 407 & $20 / 08 / 2012$ & $\begin{array}{l}\text { Define novas regras para o PMCMV em } \\
\text { municípios de até } 50 \text { mil habitantes. }\end{array}$ \\
\hline Portaria N. 435 & 20/08/2012 & $\begin{array}{l}\text { Estabelece valores máximos de aquisição de } \\
\text { UHS contratadas com recursos oriundos do } \\
\text { FAR - PNHU (Sobrepõe Portaria N. 140). }\end{array}$ \\
\hline Decreto N. 7.825 & $15 / 10 / 2012$ & $\begin{array}{l}\text { Eleva o limite de renda da faixa } 2 \text { do } \\
\text { PMCMV2. }\end{array}$ \\
\hline Instrução Normativa N. 45 & $08 / 11 / 2012$ & $\begin{array}{l}\text { Eleva valores para a construção das novas } \\
\text { moradias PMCMV - Entidades. }\end{array}$ \\
\hline Portaria N. 107 & 26/02/2013 & $\begin{array}{l}\text { Estabelece as diretrizes gerais e o calendário } \\
\text { para habilitação de entidades privadas sem }\end{array}$ \\
\hline
\end{tabular}




\begin{tabular}{|c|c|c|}
\hline & & fins lucrativos. \\
\hline Instrução Normativa N. 14 & $14 / 10 / 2013$ & Regula o PMCMV - Entidades. \\
\hline Portaria N. 518 & 08/11/2013 & $\begin{array}{l}\text { Dá nova redação à Portaria N.168, que } \\
\text { dispõe sobre diretrizes gerais para aquisições } \\
\text { dos imóveis FAR no PNHU. }\end{array}$ \\
\hline Portaria N. 595 & $18 / 12 / 2013$ & $\begin{array}{l}\text { Dispõe sobre os parâmetros de } \\
\text { priorização e sobre o processo de seleção } \\
\text { dos beneficiários do PMCMV. }\end{array}$ \\
\hline Portaria N. 21 & 22/01/2014 & $\begin{array}{l}\text { Aprova o Manual de Instruções do Trabalho } \\
\text { Social nos Programas do Min. das Cidades. }\end{array}$ \\
\hline Portaria N. 274 & 10/04/2014 & $\begin{array}{l}\text { Dá nova redação à Portaria N. 168/2013 e } \\
\text { dispõe sobre as diretrizes gerais do uso dos } \\
\text { recursos FAR no PNHU. }\end{array}$ \\
\hline Resolução N. 200 & 11/08/2014 & $\begin{array}{l}\text { Revoga a Resolução N. } 194 \text { e regulamenta as } \\
\text { regras do PMCMV - Entidades. }\end{array}$ \\
\hline Portaria N. 747 & 02/12/2014 & $\begin{array}{l}\text { Dispõe sobre as condições para habilitação e } \\
\text { requalificação de entidades privadas sem fins } \\
\text { lucrativos. }\end{array}$ \\
\hline
\end{tabular}

Fonte: Tabela elaborada por Cunha (2014), atualizada com as leis posteriores a 2013.

1) Medida Provisória N. 459/2009 e Lei N. 11.977, de 7 de julho de 2009: tratam da criação e diretrizes gerais do PMCMV

Com a edição da Lei N. 11.977, instrumentalizou-se, em 7 de julho de 2009, o funcionamento dos mecanismos de incentivo à produção e à aquisição de novas unidades habitacionais; à requalificação de imóveis urbanos; e à produção e reformas de habitações rurais. A Medida Provisória N. 459 estabeleceu os dois grandes subprogramas que estruturam o PMCMV: o Programa Nacional de Habitação Urbana (PNHU) e o Programa Nacional de Habitação Rural (PNHR). Além de instituir as fontes de captação de recursos, que, posteriormente, foram ampliadas e modificadas por outros dispositivos legais, destaca-se que havia na lei a estrutura da divisão da destinação de recursos para as faixas de renda familiar.

Loureiro, Macário e Guerra (2013) observam que o papel do Congresso na elaboração do PMCMV aparece como coadjuvante, justamente, nessas regulamentações menores. No caso, a Medida Provisória N. 459/2009 seria, sob pressão, para que parte dos recursos fosse destinada aos municípios menores. Como pensado de início, o Programa se destinava a municípios de médio e grande porte, com 
população de mais de 100 mil habitantes, onde se mapeava e se concentrava o défice habitacional.

A autora há pouco referida, complementa, ainda, dizendo que houve muita pressão para se incluírem municípios menores, isso se torna atraente aos políticos municipais, em razão do grande volume de unidades financiadas, além dessa quantidade ser imediatamente convertida em benefícios de campanha eleitoral.

2) Resolução N. 141, de 10 de Junho de 2009: regulamenta o PMCMV Entidades

Essa resolução cria e regulamenta a utilização dos recursos federais destinados ao segmento do PMCMV - Entidades, voltado o atendimento às necessidades habitacionais de famílias da faixa de renda 1 , organizadas em cooperativas habitacionais ou mistas, associações e demais entidades privadas sem fins lucrativos.

3) Lei N. 12.424, de 16 de junho de 2011, e Decreto 7.499, de 16 de junho de 2011: criação da segunda fase do PMCMV

A criação, consoante a lei, da segunda fase do PMCMV se deu, paulatinamente, em um processo que perdurou um semestre. Como aponta Cunha (2014), a MP N. 514, de 1 - de dezembro de 2010 , foi o primeiro ato institucional que sinalizou sua instituição. Depois de consagrada, se concretizou na Lei 12.424 , de junho de 2011 . O procedimento iniciado com a medida provisória assinala o interesse do Governo em manter, na época, o compromisso de continuidade do Programa perante os agentes diretamente envolvidos ele, afinal, seguia-se de um ano de eleição federal.

Percebe-se no Decreto 7.499, de 16 de junho de 2011, atualização de valores previstos da Lei 11.997, de 2009, assim como o estabelecimento de outras regras para a segunda fase. A meta era contratar, em um período de quatro anos, dois milhões de unidades habitacionais por todo o País, sendo grande parte dessa demanda destinada à faixa 1, concentrando 1,2 milhão de habitações, 600 mil destinados à faixa 2 e 200 mil à faixa 3.

As atualizações com relação ao limite de renda para cada faixa reajustaram a faixa 1 em até $R \$ 1.600,00$; a faixa 2 para até $R \$ 3.100,00$; e a faixa 3 para até $\mathrm{R} \$ 5.000,00$. Junto a essas mudanças substanciais foram redefinidos os preços médios dos imóveis, e, aqui, é importante ressaltar que se ampliaram significativamente, passando de $R \$ 42.000,00$ para cerca de $R \$ 55.000,00$. Os reajustes foram tanto no 
tocante aos tetos salariais quanto aos preços das unidades habitacionais. Com a inauguração dessa etapa, o Governo anunciou o maior valor destinado à subsídio da história - da ordem de 72,6 bilhões, além dos 53,1 bilhões destinados ao financiamento, somando-se $R \$ 125,7$ bilhões para a promessa de mais 2 milhões de unidades.

A Portaria № 325, de 07 de julho de 2011, que dispunha sobre as diretrizes gerais para a aquisição e alienação de imóveis por meio de transferência de recursos ao Fundo de Arrendamento Residencial - FAR, no âmbito do PNHU, foi revogada e substituída pela Portaria N. 465, de outubro de 2011. Esta dispunha de seis anexos e se constitui como documento de grande importância para o funcionamento operacional do PMCMV, mais especificamente do PNHU, uma vez que define os agentes participantes desse segmento de atuação do PMCMV.

Foi com esse documento que se detalhou a meta do PNHU com recursos do FAR destinados a 860 mil unidades habitacionais até 31 de dezembro de 2014. Esse número foi distribuído entre as unidades da Federação, conforme estimativa do défice habitacional urbano referente às famílias com renda até três salários-mínimos.

O total das 860 mil unidades habitacionais foi distribuído conforme as regiões: Sudeste, 357.404 unidades (41,5\%); seguida a região Nordeste, com 258.679 (30,1\%); Sul, com 90.994 (10,4\%); Norte, com 79.937 (9,6\%); e Centro-Oeste, com 72.986 $(8,4 \%)$, conforme sinaliza o gráfico a seguir.

Gráfico 03: Distribuição da demanda conforme a região

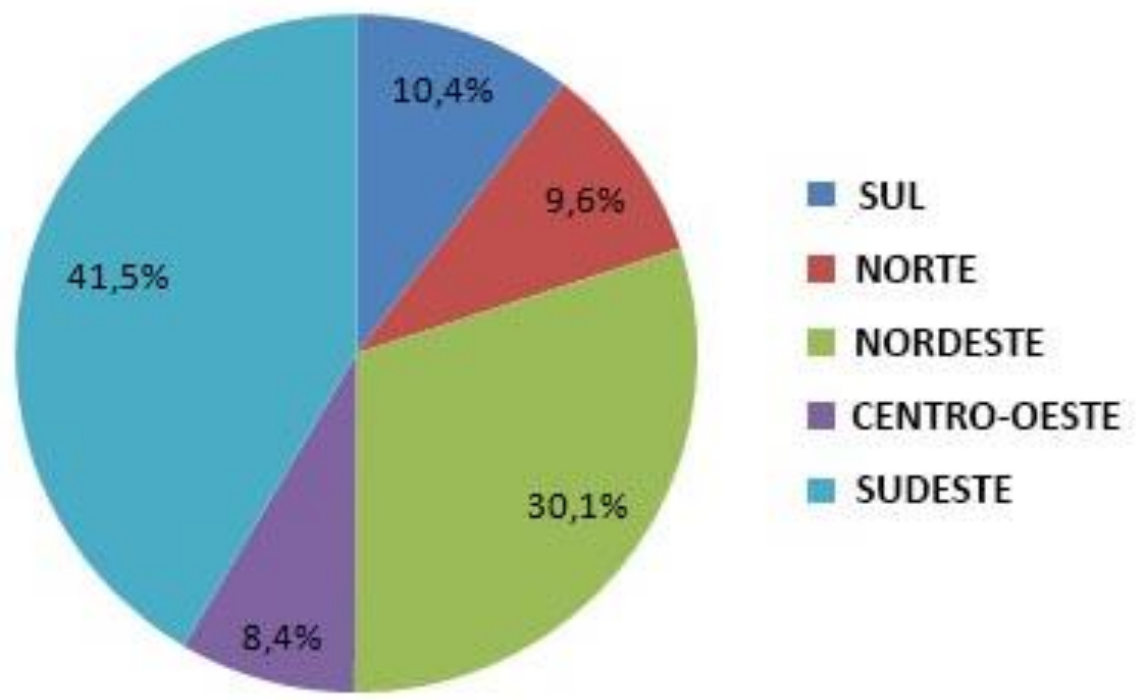


Fonte: Dados Ministério das Cidades. Organização própria.

Vale ressaltar que as distorções evidentes na distribuição dos recursos da primeira etapa do PMCMV foram constatadas não só entre regiões, mas, também, em estados específicos. Analisados os resultados, conferiu-se que, até 2011, a Bahia recebeu $11,6 \%$ das unidades habitacionais, enquanto São Paulo recepcionou $19 \%$. Em contrapartida, há estados que receberam poucos recursos, como são os casos do Ceará, 2,2\% , e do Espírito Santo, 1,8\%. O Pará, a exemplo, recebeu menos recursos do que o estado de Alagoas, sendo que o primeiro denota défice grave de habitação.

O documento há instantes mencionado expressa as IFOFs, como as instituições financeiras oficiais federais. Estas são responsáveis por encaminhar, trimestralmente, à Secretaria Nacional de Habitação do MCid o plano de metas de contratação por unidade da Federação para o trimestre subsequente. Essa menção revela que um dos poucos mecanismos de regulação e planejamento por parte do Estado junto ao PMCMV ocorre em modelo de provisão de habitações privadas. A função do Estado é de financiar, fiscalizar e estabelecer metas de contratação, contudo, na descrição da Portaria, não fica evidente como isso realmente aconteceria, se as IFOFs deveriam participar ativamente, impulsionando as contratações com aberturas de editais junto às empresas ou se apenas, passivamente, aguardaria a iniciativa do agente privado. São justamente nesses espaços que as diferenciações e as particularidades de cada território vão mostrar uma resposta diante ao PMCMV.

O documento ora citado toca ainda em questões importantes, quando define as diretrizes gerais da elaboração do projeto e suas especificações técnicas, além de orientar estudo de viabilidade dos empreendimentos. Destacam-se como relevantes para esta pesquisa as orientações dos seguintes aspectos: a obrigatoriedade dos empreendimentos serem inseridos na malha urbana ou em zonas de expansão da cidade, conforme definido no plano diretor de cada município. No caso de empreendimentos localizados em zonas de expansão urbana, deverão estar contíguos à malha urbana e possuir, no entorno, áreas destinadas a atividades comerciais locais. Todo e qualquer empreendimento deverá possuir infraestrutura, como vias de acesso e circulação de pavimentos, drenagem pluvial, calçadas, guias e sarjetas, rede de energia elétrica e iluminação pública, rede de abastecimento de água, soluções para esgotamento sanitário e serviço de coleta de lixo. 
É importante notar que, enquanto a primeira fase do PMCMV limitava as unidades a conjuntos de até 500 mil moradias, na segunda, o porte dos empreendimentos não é limitado em unidades, mas, dependendo da escala, novas exigências são feitas.

Percebe-se que a questão urbana só é avaliada sistematicamente na segunda etapa. O PMCMV começou a se efetivar tão distante da política urbana que somente no segundo ano de sua implementação foi possível observar que se desenvolveram as primeiras exigências referentes à localização dos empreendimentos. Com a Medida Provisória N. 514, se estabeleceu que os empreendimentos do PMCMV deveriam ser implantados em terrenos localizados na malha urbana ou em áreas de expansão previstas nos planos diretores municipais, além de apresentarem licenças ambientais comprovadas, infraestrutura de rede elétrica, abastecimento de água e soluções sanitárias, vias de acesso e transporte público e, por fim, deveriam dispor de serviços públicos e equipamentos de educação, saúde e lazer; no caso de uma negativa, deveriam contar com o compromisso do Poder Público de instalá-los ou ampliá-los.

A primeira medida provisória foi convertida na Lei 12.424 . Ela reforça as mesmas especificações e diretrizes, sendo expostas a seguir:

I - localização do terreno na malha urbana ou em área de expansão que atenda aos requisitos estabelecidos pelo Poder Executivo federal, observado o respectivo plano diretor, quando existente;

II - adequação ambiental do projeto;

III - infraestrutura básica que inclua vias de acesso, iluminação pública e solução de esgotamento sanitário e de drenagem de águas pluviais e permita ligações domiciliares de abastecimento de água e energia elétrica; e,

IV - a existência ou compromisso do poder público local de instalação ou de ampliação dos equipamentos e serviços relacionados a educação, saúde, lazer e transporte público ${ }^{20}$.

Além desses pontos, a Lei 12.424 prevê que os municípios devem firmar um documento oficial para cada operação do PMCMV, o denominado "Instrumento de Compromisso" que responsabiliza o Poder Público local pelas adequações das condições do entorno pelas demandas geradas com a chegada das novas unidades habitacionais.

\footnotetext{
${ }^{20}$ Brasil, Lei N. 11.977 de 7 de julho de 2009. Diário Oficial da União, Brasília, DF. 2009 seção 1, p2.
} 
Apesar de essas considerações preexistirem em lei, só, posteriormente, em 2011, com a Portaria N. 465, foi que se estruturou um procedimento de avaliação dos impactos, bem como se organizou fontes de recursos adicionais que podem ser solicitados para provisão de infraestrutura e equipamentos.

A Portaria N. 465, complementada pela Portaria N. 518, em 2013, integra mudanças com alterações importantes no tocante à escolha da localização e do terreno. No concernente à localização, os empreendimentos só podem ser implantados em terrenos contíguos à malha urbana, que deve existir no entorno de áreas servidas de infraestrutura e serviço.

Em relação ao projeto a ser executado, uma série de novas determinações foi implementada, principalmente, no que se refere aos limites de unidades e equipamentos de uso comum no empreendimento. Estabeleceu-se como obrigatória a destinação de $1 \%$ do valor da operação, em qualquer empreendimento de mais de 60 unidades, para a construção de equipamentos de uso comum na seguinte prioridade: espaço coberto para a comunidade, descoberto para recreação e lazer infantil e quadra de esportes.

Outra mudança da segunda versão do PMCMV é o fim do limite de cinco pavimentos para os prédios residenciais populares em áreas urbanas centrais e regiões metropolitanas e a possibilidade de instalação de comércio no térreo destes imóveis.

Se, inicialmente, o PMCMV define, em normas, conjuntos com no máximo de até 500 unidades, não se considerava a justaposição dos empreendimentos. Esse número ainda era mais restrito no caso dos empreendimentos construídos sob o molde de condomínio, definindo seu tamanho ao máximo de 300 unidades. Com os rearranjos legais e o incentivo para a produção voltada à faixa 1 , claramente impulsionada pelas ampliações das metas e equalização das normas para utilização do recurso FAR, a segunda etapa do Programa também traz mudanças nas apropriação dos terrenos que favoreceram a produção para as faixas de menor rendimento.

A justaposição é agora considerada e o limite passa a ser a construção de nada menos do que cinco mil unidades habitacionais, no caso de haver um empreendimento contíguo a outro, e isso ocorre quando "a menor distância, em linha reta, do ponto do perímetro da sua poligonal mais próxima ao perímetro da poligonal de outro empreendimento for igual ou inferior a 1.000 metros". (BRASIL, 2013b). Assim, o limite 
máximo das unidades integrantes de conjuntos considerados contíguos passa a ser cinco mil, constituindo um aparato legal que reforça a concentração das unidades, uma vez que na habitação popular existe a tendência da concentração espacial das unidades em grandes conjuntos, em uma produção que pode negar a arquitetura e quebrar sua relação com a Cidade.

O padrão de produção do Programa, imposto pela lógica da escala industrial almejada pelas grandes empresas, se sobrepõe às condições locais e a qualquer diretriz própria dos processos de projeto que se desenvolvem a partir de situações específicas. (AMORE, SHIMBO \& RUFINO, 2015, p. 64).

Esse limite, contudo, ainda pode ser extrapolado quando condicionado à autorização do Ministério das Cidades. Estes empreendimentos, apesar de considerados de maior escala, ganham condições especiais. Para qualquer projeto de mais de 1.000 unidades, passa a ser obrigatória a destinação de área para a implantação de equipamentos públicos necessários ao atendimento da demanda gerada. Em 2013, com a Portaria N. 518, essa definição foi levada aos empreendimentos de mais de 500 unidades, o que representou um ganho ao incremento da qualidade para essas moradias.

Por fim, as principais inovações trazidas pela Portaria N. 465 são a elaboração de documentos para a aprovação dos projetos. Em empreendimentos de mais de 500 unidades, seriam necessários o "Relatório de Diagnóstico da Demanda por Equipamentos Públicos e Urbanos" e a "Matriz de Responsabilidades". Na elaboração do Relatório é descrito a interferência de equipamentos situados em uma área situada dentro do raio de $2,5 \mathrm{~km}$ ao redor do empreendimento. Nesse raio, identificam-se os equipamentos comunitários e serviços - em curso ou previstos - assim como sua capacidade de atendimento. Nesse relatório, também são expressos os padrões de uso e ocupação do solo, se existem fatores de risco e insalubridade, áreas de zoneamento industrial, aterros, lagoas em tratamento, assim como outros empreendimentos de habitações de interesse social.

Depois de quantificar e qualificar as demandas no relatório, as medidas necessárias para seu atendimento são especificadas na Matriz de Responsabilidades, que deve exprimir um cronograma de implementação das obrigações assumidas. Apenas em empreendimentos acima de 1500 unidades, contudo, é que se exige a 
homologação desses documentos por parte de representantes do Ministério das Cidades e da instituição financeira federal envolvida na operação, no caso, Caixa ou Banco do Brasil.

Outra importante mudança foi a previsão de recursos adicionais do FAR para implantação de equipamentos complementares à habitação. Em empreendimentos acima de 500 unidades, é possível que o FAR disponibilize recurso para serviços de educação, saúde e segurança pública. É importante demarcar a ideia de que essa é uma operação custeada pelo Poder Público local e que deve ser implementada em uma distância de até $1 \mathrm{~km}$ do empreendimento.

As descrições das diretrizes urbanísticas são definidas com vistas a constituir um quadro que expresse os itens que devem servir de base para o critério das escolhas de terrenos e áreas de implantação dos empreendimentos do PMCMV. Com o passar dos anos, elas se alteram e passam cada vez mais a definir e qualificar procedimentos que consideram a inserção urbana dos empreendimentos do Programa.

Do ponto de vista legal, o PMCMV define critérios restritivos acerca das qualidades do terreno e de algumas indicações da localização quanto à inserção do empreendimento na malha urbana. Foram delegadas aos contratantes dos empreendimentos a prática e a operacionalização do Programa, ficando muitas vezes ao encargo da iniciativa privada encontrar e escolher um terreno passível de iniciar o empreendimento.

Se, inicialmente, o PMCMV tinha critérios praticamente vazios em termo da escolha da localização, com a sua evolução, se expressa alguma clareza e certas definições quanto à necessidade de equipamentos e serviços públicos. Note-se, porém, sobre a infraestrutura urbana que muito nem mesmo passa pela legislação do Programa. Como lembra Pádua (2015), "é possível afirmar que a legislação atual não diz nada sobre o transporte público, ou o acesso à cidade em grandes centros urbanos, pontos essenciais para evitar ou mesmo atenuar a possível segregação gerada pelo Programa". (P. 54). 


\subsubsection{Síntese da análise da legislação}

A análise da legislação demonstra que o PMCMV não surgiu com seu aparato legal e institucional definitivo e estruturado, e, sim, foi se adaptando e se aprimorando ao longo de sua implementação. Os diversos interesses e conflitos gerados na execução do Programa fizeram com que medidas, por vezes mais restritivas ou mais permissivas, fossem regulamentadas primeiro no plano federal, e, por assim conseguinte, nos demais âmbitos de gestão. Essa realidade, no entanto, não é exclusiva desse Programa específico, como expressam Loureiro, Macário e Guerra (2013):

No PMCMV, como em outras políticas públicas, não há a separação clara entre formulação e implantação, tanto em termos de atores participantes como em relação às decisões tomadas em seu curso, ou seja, parte do desenho da política foi redefinida no momento de sua execução como resposta do governo e da burocracia gestora a demandas sociais não contempladas, às restrições impostas por órgãos de controle e mesmo a críticas de especialistas e de movimentos sociais. Assim, a Casa Civil da Presidência da República, núcleo central da formulação, continuou desempenhando papel principal no processo de sua implementação, como órgão de coordenação centralizada. (P. 23).

Observando a linha do tempo das principais portarias e normas selecionadas, assim como o detalhamento da legislação mais significativas do PMCMV que interessa ao foco desta pesquisa, se verifica que o Programa se inicia com a aprovação de medidas mais gerais que Ihe concedem corpo legal, onde são definidas as fontes de financiamento, os valores de tetos, a hierarquização de atendimento, entre outros. Só posteriormente, surgem os instrumentos mais restritivos e específicos, que parecem tentar regular melhor o que as medidas gerais não puderam controlar ou mesmo não consideraram, anteriormente, no escopo do Programa sob comento.

A maior parte do aprimoramento da legislação, como consta no próprio site do Governo Federal, ocorreu na com a aprovação da segunda fase do PMCMV. Foi depois de 2011 que se reajustaram os valores da faixa de renda, se ampliaram escopos e metas e se focalizaram massivamente na faixa 1 , assim como se tentou melhorar os requisitos e as especificações para o interior das unidades habitacionais. 
Paralelo ao aprimoramento das especificações construtivas do interior das habitações, em termo de inserção urbana, o Programa delimita especificidades e amarra suas exigências. À medida que o Programa se amplia e se adapta para alcançar as faixas de menores renda por meio de normativas, também, possibilita a realização de conjuntos que concentram maior número de unidades habitacionais. 0 desdobramento da legislação passa a permitir maiores escalas dos empreendimentos e, posteriormente, requer equipamentos que culminam em nova legislação que delimita e exige alguma qualidade do espaço e infraestrutura urbana. Essa é uma mudança crucial que terá grandes repercussões no tamanho dos empreendimentos e nas contratações via empresas construtoras e incorporadoras.

Cunha (2014), a esse respeito, suscita um importante ponto: como um Programa desse vulto se dá início com uma legislação que só tocava o essencial e indispensável para seu andamento? A própria recuperação da legislação mostra que o PMCMV funcionou em seus primeiros quatro meses de andamento com apenas uma Medida Provisória. Nota-se que esse tipo de legislação é um ato imediato e restrito ao Presidente da República, sem a participação do Poder Legislativo. Levanta-se, em consonante com Cunha (2014), a ideia de uma aprovação de caráter emergencial, onde não se discutiram consensos entre os poderes, e, em razão do teor do documento, parece que ele esteve inicialmente muito mais voltado para o desenvolvimento econômico em curto prazo do que de fato interessava orientar questões verdadeiramente habitacionais e urbanísticas.

Durante toda a primeira etapa do PMCMV, esse foi o tom, quando só em 2011 a legislação pareceu apurar especificações e orientações técnicas, além de indicativos de estudos de viabilidades e requisitar análise especial de alguns empreendimentos. É sintomática a passividade em razão da grande quantidade de moradias com baixa qualidade arquitetônica e urbanística. O atraso na regulação pode ter favorecido, em escala nacional, o problema de uma rápida expansão urbana de baixa qualidade.

Outro ponto sobressaído dessa leitura é que, apesar das descrições e recomendações previstas pelas portarias aprovadas, elas não são tratadas rigidamente. Isto significa que os empreendimentos não devem, necessariamente, cumpri-las à risca. Em caso de definições de extrema importância, como a escolha da sua localização, ao rigor da lei, se diz que os conjuntos devem estar contíguos à malha 
urbana ou em zonas de expansão urbana, contando com equipamentos e infraestrutura. Contudo, como será visto posteriormente, esse aspecto se tornou ponto frágil na operacionalização do Programa.

Essa máxima é facilmente driblada na indefinição e na amplitude que o plano diretor de cada município atribui às áreas escolhidas, uma vez que não é raro os planos darem definições distintas a essas regiões. A ordem das especificações parece ser sempre conduzida na lógica de parâmetros mínimos, aparentando existir uma aura de baixa exigência relativamente à produção dos agentes privados, quando o Estado regula claramente os critérios a serem cumpridos.

Em virtude dessas questões Cunha (2014) aponta a noção de parecer que o PMCMV não foi pensado com o interesse de resolver o problema habitacional no Brasil, pois, sua ordem é econômica. E mais: seu arcabouço institucional não se orienta para resolver entraves na gestão pública e, sim repassá-los para decisões de empresas privadas. A legislação do PMCMV opta, claramente, por uma produção diretamente de mercado, dispensando a gestão municipal, principalmente, quando não resolve os entraves anunciados com seu ato de se constituir como Programa. É assim que a política pública parece resolver os entraves - contornando as dificuldades e gerando um sem-número de outras, quando diminui a articulação de todos os poderes na regulação da atividade produtiva por parte das empresas privadas.

Nesse mesmo ponto, se considerado o arranjo institucional da implementação pelo ângulo democrático ou de maior inclusividade de agentes e demandas ao curso que o Programa se desenvolve, cabe indicar que ele exprime lacunas. Se o empresariado da construção civil teve suas demandas atendidas quanto às suas recomendações, desde a elaboração do desenho do Programa, sejam elas referentes ao teto do imóvel quanto às questões de sua operacionalização, o mesmo não ocorreu com outros segmentos sociais.

Não é foco deste trabalho a questão participativa ou democrática do Programa, mas, é um ponto a ser considerado: o fechamento das decisões do PMCMV em dois segmentos, a gestão federal e as demandas do segmento da construção civil.

É possível perceber que as regras para a produção do Programa foram estabelecidas de maneira incremental e continuaram se modificando desde o seu lançamento, questionando, assim, a ideia de um Estado que não atua, em razão da 
grande quantidade de portarias e decretos que se multiplicam em uma continuidade de adaptações. O Ministério das Cidades, como visto, estabeleceu várias instruções normativas. Além disso, a Caixa formulou inúmeros manuais e procedimentos aplicáveis às operações do FAR e ao apoio à produção e ao imóvel na planta. Compreender essas regras é importante, pois estabelece como o processo de produção habitacional ocorre, dando atribuições a cada agente envolvido.

No subitem a seguir, descrevem-se algumas das regras de contratação de empreendimentos, distinguindo diferenças entre as aprovações de projeto nas distintas faixas e explorando com detalhes as distinções entre a faixa 1 (designada habitação social) e as faixas 2 e 3 (comumente chamadas de mercado popular).

É importante destacar o fato de que, justamente, no ponto crucial para este trabalho - a escolha de terreno - as diferenças entre a produção do PMCMV para as distintas segmentações de faixas de rendas são diversas. Por esse motivo, se estenderá um pouco mais sobre as regras de escolha de terreno e a produção imposta. Como se verá, o desígnio do Programa já define, de certa forma, as empresas que preferencialmente irão atuar em cada segmento.

\subsubsection{Operacionalização do Programa Minha Casa Minha vida: as regras de} contratação

Uma vez que esta pesquisa concentra esforços para entender as definições de localizações e escolhas de terrenos, se faz necessário entender melhor algumas regras a respeito da aquisição da terra. Algumas grandes diferenças distinguem o papel desempenhado pelas empresas que atuam junto à faixa 1 daquelas que operam nas faixas 2 e 3 do Programa - papel esse previamente estabelecido por meio de portarias.

Busca-se, aqui, explorar as diferenças entre os segmentos da faixa 1 chamados de habitação social - e os das faixas 2 e 3 - comumente associados ao que se chama mercado popular ou econômico.

Salienta-se que esta investigação cuida dos produtos desenvolvidos com o setor imobiliário, as empresas imobiliárias e da construção civil da RMF. Por esse motivo, concentra- se nos produtos do Plano Nacional de Habitação Urbana - PNHU, integrante do PMCMV. A organização do fluxo operacional do PMCMV muda de acordo com as 
regras da sua execução nas faixas 1, 2 e 3, e cada segmentação tem fundo de financiamento próprio e regras específicas.

O PNHU, por sua vez, também é dividido em dois grandes segmentos, pois leva em consideração a renda auferida pela população demandante. A primeira segmentação engloba a população com renda de zero a três salários-mínimos - faixa 1, comumente chamado de Habitação de Interesse Social, e a segunda segmentação abrange a população que recebe até dez salários mínimos, chamada de segmento econômico que engloba as faixas de renda 2 e 3.

Na perspectiva de Ferreira (2012), apesar de bastante amplo no que se refere às faixas de renda, o PMCMV "na pratica pode ser visto como uma política com diferentes estratégias de atendimento conforme a faixa de renda da população". (P.40).

Para o segmento de baixa renda, sua implementação depende do grande apoio das prefeituras, pois são elas as responsáveis pelo cadastro dos beneficiados e pela indicação dos demandantes. O financiamento dessas moradias deriva do Orçamento Geral da União (OCG), a fundo perdido, e é gerido pela Caixa Econômica Federal apor meio do Fundo de Arrendamento Residencial (FAR).

Vale ressaltar que as famílias demandantes podem estar organizadas em associação e não, por necessário, isoladamente, constituindo-se em cooperativas, associações ou sociedades outras sem fins lucrativos. Esse atendimento é mais bem sintetizado no fluxograma exposto na figura abaixo. 
Figura 01: Fluxograma da organização das famílias demandantes

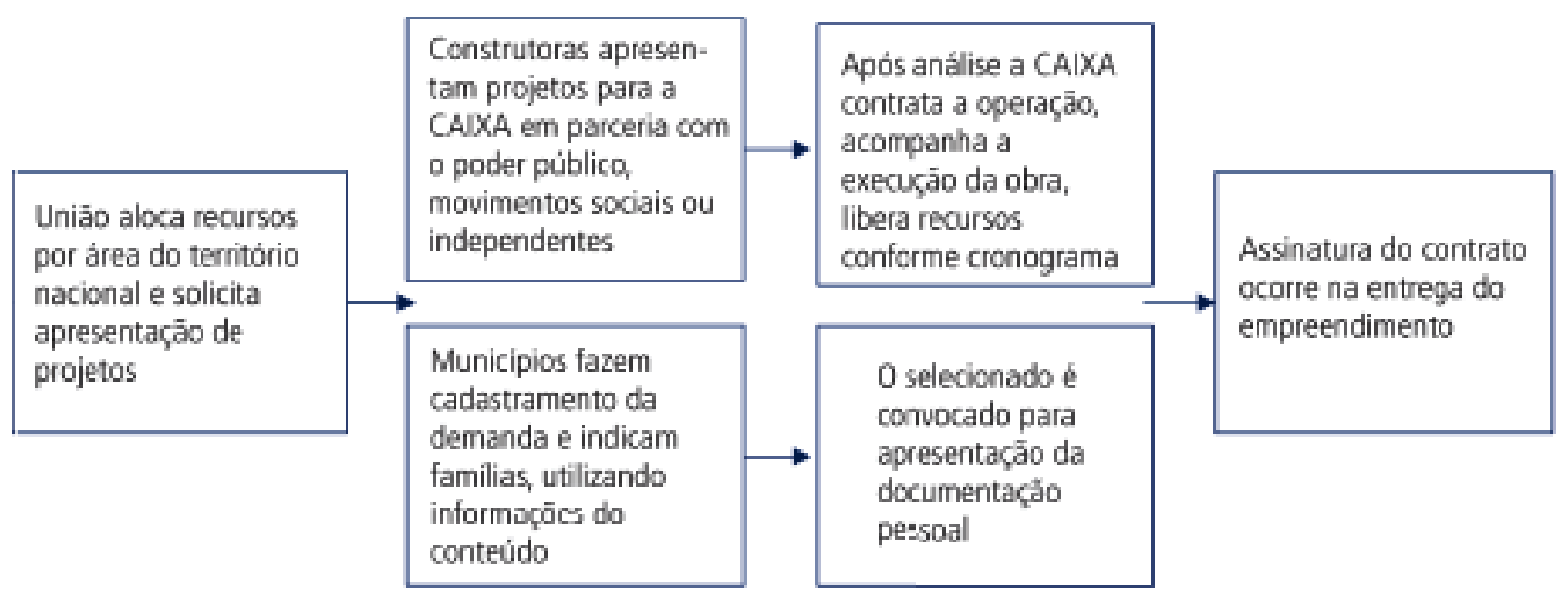

Fonte: Cartilha Caixa Econômica Federal

A ideia de que na faixa 1 não há a atividade de incorporação pode ser discutida, quando, por definição, se segue o pensamento de Ribeiro (1997), ao conceber como incorporador o "iniciador e organizador do processo de produção de moradia", incluindo como atividades exercidas por esse agente as de concepção do empreendimento, tais como a análise de mercado, a escolha do terreno e sua valorização, além da promoção e venda das unidades habitacionais, sejam elas prontas ou não, entre outras funções.

Para Ribeiro (1997) e Topalov (1974), o que distingue o capital de incorporação dos demais é que, em dado momento de seu ciclo, a propriedade de habitação e de terreno pode se beneficiar com as mudanças na organização do espaço, ensejando sobrelucros de localização. Havendo na própria atividade de organização a possibilidade de

Constata-se que a produção para o PMCMV, principalmente na faixa 1, denota uma série de regras diferentes da produção para o mercado em geral. As especificidades do financiamento da produção para a população de baixa renda tornam-se decisivas nas relações dos agentes imobiliários com os demais envolvidos nessa produção imobiliária, assim como a definição de suas estratégias. As empresas devem procurar e encontrar uma área na Cidade onde viabilizem a construção um empreendimento, desde que esteja de acordo com a legislação do PMCMV. É logo 
nessa etapa inicial - escolha do terreno - que surgem as diferenças entre a produção para a primeira faixa e as seguintes.

$\mathrm{Na}$ produção de moradias para a faixa 1 , as características dos empreendimentos são estabelecidas pelo Ministério das Cidades, e não há a necessidade de uma análise de situação de mercado, pois o que determina a contratação do empreendimento é o défice habitacional e o cadastro dos beneficiários efetuado pelo município. Deste modo, não haveria risco para compra e venda das unidades. $\mathrm{O}$ fato de não haver a etapa de comercialização das unidades é uma grande diferença; a demanda já é garantida pela determinação do défice. Sabe-se que, na realidade, os riscos de produção, em virtude da pequena margem de preços e tetos dos valores de unidade são os reais desafios para essas empresas construtoras e incorporadoras, que são atraídas para esse ramo de atuação.

Na faixa de renda de 0-3 SM as únicas variáveis abertas para avaliação da atratividade destes empreendimentos são: (1) custo de construção, (2) inflação setorial (INCC), (3) preço do terreno, uma vez que o preço das unidades é fixo e não há risco de mercado ... Estas características assemelham este tipo de empreendimento às obras contratadas em regime de empreitada por preço global, portanto, é mais voltado às empresas empreiteiras, do que aos empreendedores do mercado de real estate residencial. (GREGÓRIO, 2011, p. 2).

Sendo assim, entende-se que as empresas construtoras de habitação para a faixa 1 não maximizam seus ganhos com a comercialização, e sim, por meio de sobrelucros da diferença de preço de terrenos entre a melhor e a pior localização.

Sobre o terreno, este pode ser adquirido sob três aspectos: o terreno pode ser de propriedade da construtora, pode ser propriedade de um terceiro ou pode ser uma doação do poder público local. Cada situação específica situa a empresa construtora ou incorporadora em contato com distintos agentes, e é importante destacar oferta de que esse contato passa sempre pela triangulação da mediação da instituição avaliadora, a Caixa Econômica Federal. Nas duas primeiras, ocorre a venda do terreno para o FAR; e, na terceira, a prefeitura assina um termo de doação do terreno ao mesmo Fundo. Em ambas, o FAR passa a ser o proprietário do terreno no qual será construído o empreendimento para a faixa um de renda.

É na esfera federal, por meio do Ministério das Cidades que são estabelecidas as condições mínimas de boa localização. O próprio valor máximo desse terreno é 
previamente estabelecido, sendo difícil atrelar a ideia de uma valorização à compra desse terreno. Regra geral, o valor do terreno não pode ser repassado à vista pela CEF, limitando-se a $10 \%$ do preço total das unidades, que, por sua vez, é definido em tetos máximos, de acordo com sua região.

Apesar da discussão levantada por alguns estudiosos quando questionam se a faixa 1 do PMCMV é realmente "mercado" para as empresas, uma vez que tem participação ativa das prefeituras no cadastro dos beneficiários e, muitas vezes, na escolha do terreno, é importante destacar que, dentro da produção para baixa renda, o agente privado tem absoluto predomínio sobre as unidades produzidas.

Em sua pesquisa Cunha (2014) destaca que dentre os agentes operantes nessa faixa, é possível verificar a clara hegemonia das empresas que, identificadas por meio de CNPJ, respondem sozinhas a $66 \%$ do número de agentes. Esse número corresponde a dados nacionais e quer dizer que mais da metade dos CNPJ que solicitaram apoio a financiamento para a produção de moradia correspondem às empresas de construção e incorporação - fato revelador de que o setor privado é, sim, o principal fomentador do PMCMV na baixa renda, também.

Considerando o número de unidades habitacionais contratadas com recursos do FAR para a faixa 1, o agente privado também aparece com força inquestionável. Cunha (2014) exprime, com base em dados da CEF, no âmbito nacional, que as contratações para essa faixa, sejam elas para imóvel rural ou urbano, contratos por empresas ou por entidades organizadas, contratações por prefeituras, ou qualquer um dos produtos possíveis, concentram $90 \%$ das unidades contratadas nos CNPJs de empresas. Pode-se falar, portanto, de uma hegemonia absoluta das empresas de construção e incorporação no Programa, mesmo na faixa em que o poder dos municípios é mais atuante. Essa realidade pode ser mais apreciada no gráfico abaixo. 
Gráfico 04: PMCMV - Contratação por tipo de agente

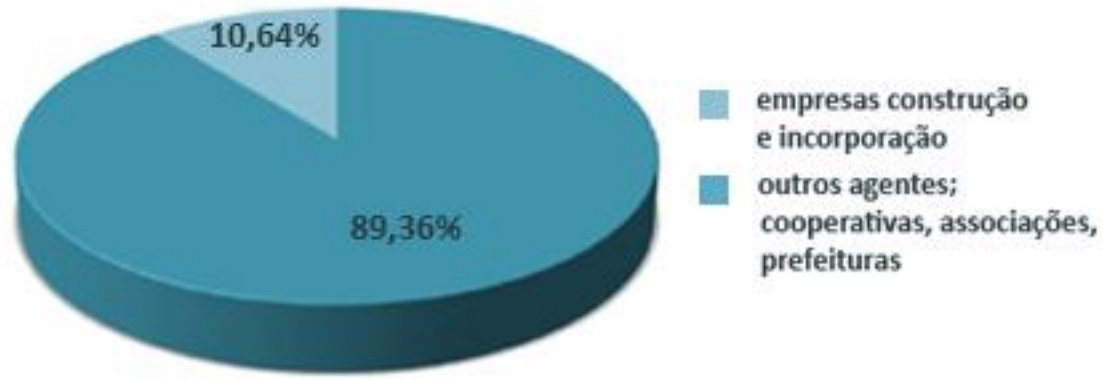

Fonte: Autor Cunha (2014). Contratação por tipo de agente - faixa 1

No segmento econômico ou popular em que se concentra o financiamento para as unidades na faixa 2 e 3 do PMCMV, a figura da indústria imobiliária, da incorporação ou da construção, assume, claramente, o papel de incorporadora. A empresa possui a liberdade para conceber as características do empreendimento e criar as próprias estratégias de venda e comercialização.

Com efeito, essas empresas coordenam as escolhas de seus terrenos, quando podem lucrar com maior flexibilidade com a diferença entre o valor pago pelo terreno e o novo valor criado com a valorização da área no ato de instituir a habitação. Ao narrar essa estrutura, pode-se pensar que o mercado popular segue a mesma base estrutural de um mercado de alta renda tradicional para famílias com renda de mais de dez salários-mínimos, contudo, o PMCMV estabelece regras e, principalmente, valores máximos pelos quais as unidades habitacionais podem ser vendidas, sendo vetado à empresa vender mais caro do que o preço estabelecido em sua região.

A construção civil, que amplamente se valia do sobrelucro da incorporação dos empreendimentos, depara um valor fixo, havendo toda uma reorganização da produção. As estratégias de maximização dos lucros agora operam em limites bem mais claros. A indústria da construção civil passa, mesmo nas faixas 2 e 3, por uma racionalização crescente. Cabe à empresa montar suas estratégias e rumos para atuar dentro das regras estabelecidas. Há casos paradigmáticos de empresas de capital aberto que operam em todo o Estado nacional na execução dessas unidades, especializando-se na produção do que foi chamado, pelo próprio mercado imobiliário, de novo filão do mercado, a produção para as faixas 2 e 3 do PMCMV.

A produção para as diferentes faixas de renda é diferenciada, principalmente, pela etapa de comercialização, que ocorre da seguinte maneira: a construtora 
apresenta projeto do empreendimento à Superintendência Regional da CEF, que, por sua vez, realiza uma pré-análise, a fim de autorizar o lançamento e a comercialização. Durante o período em que se conclui a análise, a empresa precisa comprovar uma comercialização mínima exigida. Assim sendo, pode ser assinado o contrato de apoio à produção para a liberação de crédito de financiamento ao empreendimento, conforme esclarece o fluxo na figura a seguir:

Figura 02: Fluxograma da operacionalização da faixa 1 - PMCMV

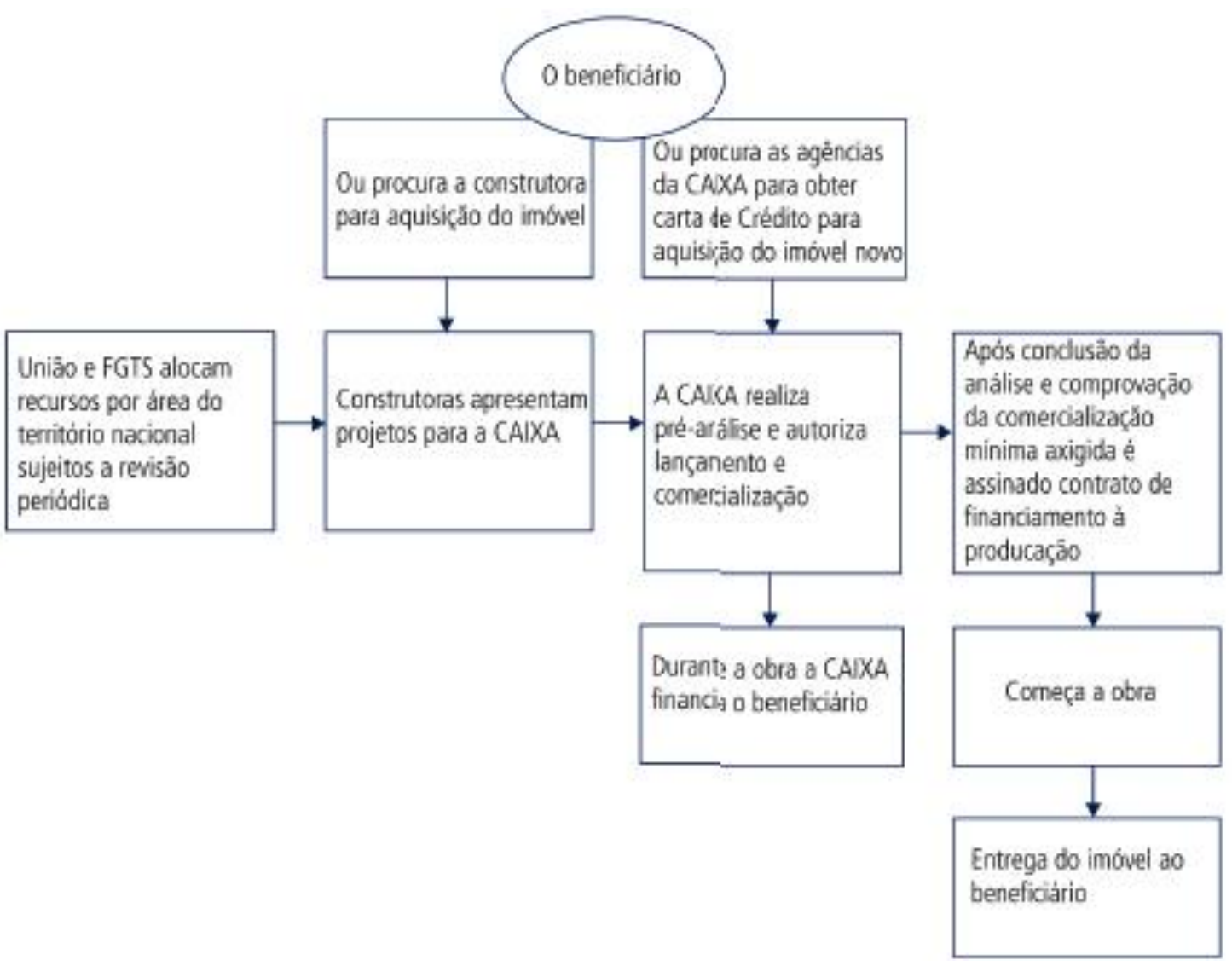

Fonte: Cartilha da Caixa Econômica Federal.

Esse fluxo de operacionalização, juntamente com as regras de subsídio e teto das habitações, traz à faixa 2 outra dinâmica, atraindo tipos específicos de empresas e estabelecendo regras diferentes ao jogo.

Verifica-se diferença, também, na contratação e aprovação do projeto da empresa construtora. Na faixa 1, terá uma análise técnica pela CEF, uma análise da capacidade da empresa para a construção e conclusão da obra, além dos aspectos 
legais e jurídicos acerca do terreno e seu proprietário. Enquanto isso, nas faixas 2 e 3, como descrito anteriormente, o processo é subdividido em diferentes etapas e não somente uma análise técnica e jurídica para a viabilização do financiamento.

Essas etapas são o enquadramento, a hierarquização, a seleção e a contratação da proposta. No enquadramento, são analisados

(...) a verificação da existência de compatibilidade entre o valor de financiamento solicitado e a capacidade de pagamento do proponente; e verificação da viabilidade técnica, comercial, jurídica e econômico-financeira do empreendimento, na forma que vier a ser regulamentado pelo agente Operador $^{21}$.

Uma vez que o empreendimento é enquadrado, inicia-se a segunda etapa, a hierarquização dos projetos proprietários, aqueles que receberiam os recursos financeiros primeiramente para o início de suas obras. Uma vez hierarquizadas, as propostas entram na fase de contratação de crédito, finalmente, recebendo recursos para o início do cronograma de suas obras e implementação.

Quadro 06: Diferenças da legislação para cada faixa de renda

\begin{tabular}{|c|l|l|}
\hline Variáveis & \multicolumn{1}{|c|}{ Faixa 1 } & \multicolumn{1}{c|}{ Faixa 2 e 3 } \\
\hline Origem do Recurso & FAR e FDS & FGTS \\
\hline Subsídio & $\begin{array}{l}\text { 5\% do Salário mensal da família, ou } \\
\text { parcela mínima de R\$ 25,00 }\end{array}$ & $\begin{array}{l}\text { Máximo de 25 mil, inversamente } \\
\text { proporcional à renda mensal da família }\end{array}$ \\
\hline Legislação & $\begin{array}{l}\text { Portaria 168 de 2013 (FAR), e Instrução } \\
\text { Normativa 14 de 2013 (FDS) }\end{array}$ & Instrução Normativa 33 e 35 de 2012 \\
\hline $\begin{array}{c}\text { Manual Disponibilizado } \\
\text { pela CEF }\end{array}$ & $\begin{array}{l}\text { Far - PMCMV - Manual de Normas e } \\
\text { procedimentos operacionais - MNPO }\end{array}$ & $\begin{array}{l}\text { Manuais de fomento pessoa jurídica - } \\
\text { Apoio à Produção e Carta de Crédito } \\
\text { Associativo }\end{array}$ \\
\hline Terreno & FAR adquire & A empresa adquire \\
\hline $\begin{array}{c}\text { Qualidade da Localização } \\
\text { Processo de Aprovação }\end{array}$ & $\begin{array}{l}\text { Legalmente, o terreno deve ter vias de } \\
\text { acesso, infraestrutura urbana e } \\
\text { equipamentos públicos }\end{array}$ & $\begin{array}{l}\text { Legalmente, o terreno deve ter vias de } \\
\text { acesso, infraestrutura urbana e } \\
\text { equipamentos públicos }\end{array}$ \\
\hline & $\begin{array}{l}\text { Dividido em enquadramento, } \\
\text { hierarquização, seleção e contratação, } \\
\text { analisado pela GIDUR e Jurídico }\end{array}$ \\
\hline
\end{tabular}

Fonte: Dados da legislação sistematizados por Pádua (2015), adequação e produção do quadro pela autora.

Como a tabela sugere, o FAR é a fonte de captação para a faixa 1. Enquanto o FGTS alimenta as faixas 2 e 3 . As diferenças entre a realização e produção para as

${ }^{21}$ Brasil, 2012, seção 1, p.2. 
distintas faixas de renda vão muito além do desenho institucional, essa é regra do jogo definida pelo PMCMV. É importante perceber que as condicionantes para a aquisição do terreno, assim como para o processo de análise da aprovação de projeto e mesmo compreender que a origem dos recursos é distinta.

O próprio desenho do mercado imobiliário local, as particularidades do território e sua história são indicativos importantes, ou mesmo fundamentais, que, associados à compreensão do desenho da política habitacional impõe, são os elementos investigados para a discussão do que essa dissertação se propõe.

Compreender essas diferenças, constantes na tabela acima, é entender que a origem dos recursos de cada programa é distinta, ou seja, o FAR para a faixa 1 e o FGTS para as faixas 2 e 3 . Com base nesse entendimento, busca-se, agora, no capítulo a seguir, entender o papel desses diferentes agentes na implementação do PMCMV no contexto da Região Metropolitana de Fortaleza. 
A Região Metropolitana de Fortaleza: a formação da Metrópole e sua estrutura de provisão de habitação

\subsection{A Região Metropolitana de Fortaleza e suas particularidades}

\subsubsection{A formação da Metrópole}

A Região Metropolitana de Fortaleza (RMF) foi criada pela Lei Complementar N.14, de 8 de junho de 1973, que instituía, também, outras regiões metropolitanas no País $^{22}$. Formada de maneira compulsória durante o regime civil-militar por meio de medida federal de deliberação de regiões metropolitanas nacionais, a RMF teve sua criação antes de sua devida metropolização ${ }^{23}$. Aliás, a região Nordeste denotava desenvolvimento urbano tardio, decorrente da sua industrialização ainda em curso.

A RMF, originalmente, foi composta por apenas cinco municipalidades: Fortaleza, seu núcleo principal, e Aquiraz, Maranguape, Pacatuba e Caucaia, municípios ainda essencialmente rurais. Objetivavam-se com essa realização o planejamento integrado do desenvolvimento econômico e social, bem como a articulação entre municípios da região para a execução de serviços de interesse comum, conforme o texto da lei.

A RMF passou por sucessivos desmembramentos de municípios e anexação de outros novos, se reconfigurando continuamente. A estratégia espacial de avanço de territórios e incorporação de novas regiões responde ao projeto de desenvolvimento em curso de cada momento. Hoje, a RMF é oficialmente composta por 19 municipalidades: Aquiraz, Caucaia, Eusébio, Fortaleza, Guaiúba, Itaitinga, Maracanaú, Maranguape, Pacatuba, Pacajus, Horizonte, Chorozinho, São Gonçalo do Amarante, Pindoretama, Cascavel, Paracuru, Paraipaba, Trairi e São Luís do Curu, conforme Lei Complementar N.144, de 04 de setembro de $2014^{24}$.

\footnotetext{
${ }^{22}$ A mesma lei estabelecia as regiões metropolitanas de São Paulo, Belo Horizonte, Porto Alegre, Recife, Salvador, Curitiba e Belém.

${ }^{23}$ Milton Santos (1990) indica processos decisivos na urbanização brasileira que indicam a metropolização do espaço: "a dissolução da metrópole" e "a fragmentação da metrópole". O primeiro processo diz respeito à celeridade da presença da metrópole, no território, o segundo identifica a organização socioespacial da metrópole pela imobilidade relativa das pessoas mais carentes. Desse modo, a metropolização não significa a concentração nas metrópoles e suas regiões metropolitanas, mas o novo momento da produção do espaço, que é ao mesmo tempo concentração e desconcentração, homogeneização e fragmentação, polarização e difusão.

${ }^{24}$ Segundo a legislação mais atual LEI COMPLEMENTAR №144, 04 de setembro de 2014. É importante notar que para a instituição do PMCMV constavam apenas 15 municípios.
} 
A própria ampliação da RMF com a entrada dos Municípios de Paracuru, Trairi, São Luis do Curu e Paraipaba se articula na fala dos agentes políticos com o PMCMV. Dadas as dinâmicas que influenciam essa frente de crescimento com o Complexo Industrial e Portuário do Pecém, uma série de novas demandas passa a ser prevista e esses municípios passam a participar do planejamento da RMF, aumentando consideravelmente os próprios orçamentos.

A inclusão desses municípios com população menor do que 50 mil habitantes junto ao PMCMV é considerado um benefício, um ganho imediato ${ }^{25}$. Apesar de só serem inclusos em 2014, já em 2015, os municípios de Trairí e São Luis do Curu já contratavam unidades, diferindo de outros que, desde o lançamento do Programa, permaneceram sem aprovação de qualquer projeto.

O esquema do gráfico abaixo pode melhor clarear o avanço territorial e a evolução da RMF. Embora seus primeiros esforços remontem ao período desenvolvimentista do Estado autoritário e sua ação seja, principalmente, direcionada ao crescimento industrial regional, a sucessiva incorporação de novos territórios favoreceu o seu superdimensionamento e as repercussões afetaram tanto no tamanho da cidade central (Fortaleza) quanto na ampliação de sua região, agrupando municípios pouco populosos, com baixa densidade e base econômica predominantemente rural.

${ }^{25}$ Consultar entrevista no site da Assembleia Legislativa: http://www.al.ce.gov.br/index.php/oradoresexpedientes/item/33365-09-09-2014-Is01 
Mapa 01: Evolução da RMF
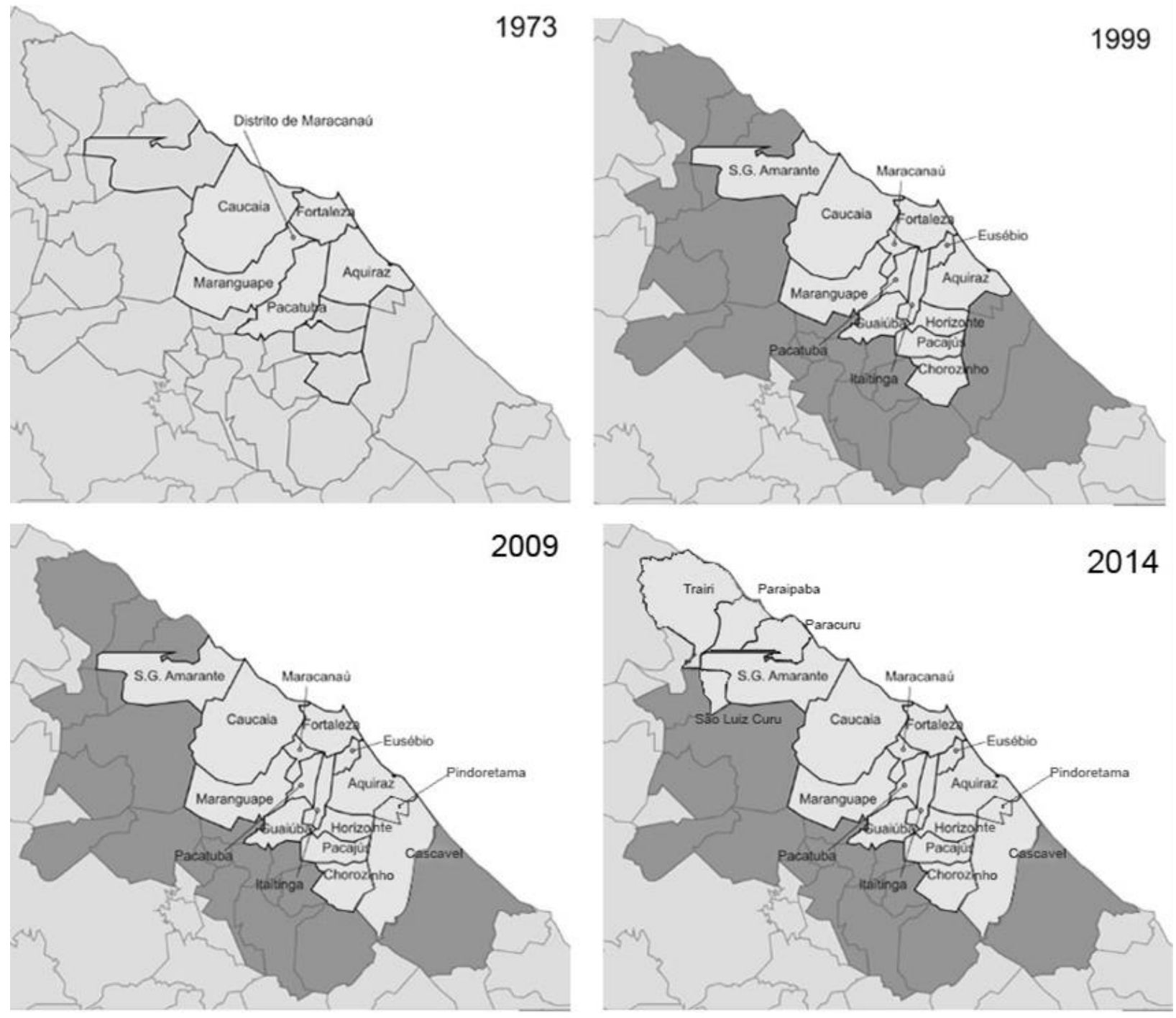

Fonte: Atualização da base de Thêmis Aragão (2011). Editou-se, com versão atualizada.

No Ceará, apesar da definição da região metropolitana e das ações a favor da industrialização e modernização que representavam iniciativa direta do Estado encabeçadas pela Superintendência de Desenvolvimento do Nordeste (SUDENE) ${ }^{26}$, essas políticas concentraram-se espacialmente em Fortaleza e só denotaram resultados mais efetivos depois dos anos de 1970. A condição de " atraso" da região do Ceará só foi ultrapassada com a organização do território e as políticas de

\footnotetext{
${ }^{26}$ A criação da SUDENE, em 1959, buscava uma política compensatória de investimentos para acelerar o desenvolvimento de regiões com economias deprimidas, focando, principalmente, o desenvolvimento da indústria na região. Uma política que afetou a organização territorial das cidades do Nordeste, determinante na urbanização da região que concentraria os incentivos em grandes centros urbanos, contudo, no Ceará apresenta uma latência, sendo necessários novos ciclos para a efetivação do avanço do capital industrial na região.
} 
desenvolvimento, mais claramente redefinidas nos anos 1980, quando as relações de avanço das relações capitalistas, tidas como modernas e avançadas, começaram a se concentrar em torno do capital industrial de Fortaleza, promovendo maiores mudanças no território da RMF.

Autores como Araújo (2013) e Bernal (2004) apontam que a ausência de políticas regionais ${ }^{27}$ durante o longo período que marcou os anos 1990 definiu um espaço da disputa fiscal entre os estados, com o objetivo de atrair capitais privados. Esses capitais buscavam novas frentes de investimentos e elegeram "áreas de dinamismo" em que fosse vantajoso concentrar espacialmente suas atividades econômicas.

Nesse período, ascendeu ao poder um grupo político oriundo do Centro Industrial do Ceará (CIC) que, em meados anos 1980, estabeleceu uma racionalidade pautada no discurso neoliberal de atração de investimentos. Seu principal plano de ação estaria pautado na promoção do crescimento industrial, em estratégias de atração de indústrias e capitais externos e na expansão do pólo turístico.

Essas ações foram evidenciadas no período do "Governo das Mudanças", que teve início em 1986 com a ascensão de um grupo político que marcou uma proposta de ação articulada com o setor empresarial, projeto que teve profundas mudanças na Metrópole, definindo as próprias lógicas espaciais. Afinal, o desdobramento e o crescimento de uma região estão interligados com a reestruturação de seu setor industrial. As infraestruturas que essa atividade exige têm grande influxo na estrutura urbana, sendo a migração dos eixos rodoferroviários do centro para as periferias um reflexo na organização da Cidade.

Esse aspecto é percebido em municípios vizinhos, onde se nota que a dotação de estímulos associados aos incentivos fiscais e captação de recursos favoreceu a desconcentração da atividade industrial implantada. Essas mudanças foram intensificadas nos anos de 1970, as quais Pequeno (2009) sintetiza como principais mudanças e identifica períodos de intensa transformações, como retrata a seguir:

(...) primeiro, com a criação induzida do Distrito Industrial de Fortaleza nos anos 1970, que resultou na criação do município de 
Maracanaú, antigo distrito de Maranguape; segundo, desde os anos 1990, a expansão do setor em eixos e mini-distritos ao longo das rodovias federais e estaduais, nos municípios de Horizonte, Pacajus, Pacatuba, Eusébio, Maranguape e Caucaia, vinculada à política estadual de atração de indústrias; terceiro, a criação de um complexo industrial portuário entre os municípios de Caucaia e São, ao oeste da RMF, decorrente de projetos governamentais, ainda em implantação, revisitando a lógica do desenvolvimento exógeno Gonçalo . (P. 99).

Rufino (2012) realça a ideia de que, embora nesse momento se evidencie ampla integração entre os municípios, essa dimensão é de ordem econômica. 0 Estado, ao consolidar infraestruturas, notadamente, a construção do metrô (Metrofor) ${ }^{28}$ e do Porto do Pecém, bem como a ampliação dos aeroportos e sistemas viários, prioriza as condições de circulação de mercadoria e fluxos turísticos.

Esses avanços não foram acompanhados pelo desenvolvimento urbano, que permanece marcado de contradições e disparidades que nasceram e persistem nos núcleos tradicionais desses municípios. Essa condição desigual se acentua quando se percebe que a expansão industrial para os demais municípios da RMF aconteceu articulada à periferização de uma população trabalhadora mais empobrecida.

Essa periferização é associada à produção estatal de moradia popular no Estado do Ceará, sendo percebida em amplo crescimento nos anos de 1970/80, quando foram implementados, pelo BNH, os grandes conjuntos habitacionais ${ }^{29}$ por meio das COHABs. Essa dimensão pode ser observada ao tomar a quantidade de unidades habitacionais dos nove maiores conjuntos promovidos naquela época.

Esses conjuntos se fixaram na região oeste ao sudoeste, onde já se localizava o Distrito Industrial do Ceará, constituído em 1964, no Município de Maracanaú. A dimensão desse programa federal corresponde a quase 40 mil domicílios. Lançando uma estimativa pelo número médio de ocupação por domicílio, que na época era de cinco moradores, chega-se ao valor equivalente à $15 \%$ da população total de Fortaleza nos anos 1980, realocada e distribuída em conjuntos habitacionais. (MESQUITA, 2000).

${ }^{28}$ Em 25 de setembro de 1987, foi iniciada a construção do consórcio do Trem Metropolitano de Fortaleza, por meio de assinatura do Contrato do Governo do Ceará com interveniência da União, por meio do Ministério dos Transportes. O consórcio muda de mãos e a obra se prolonga até o ano de 2012, quando finalmente foi inaugurada a primeira das 5 linhas, a linha sul, que liga Pacatuba ao centro de Fortaleza.

${ }^{29}$ Ver tese de Rérisson (2013) - Moradia, arquitetura e cidade: mudanças e permanências na produção da habitação social no espaço urbano metropolitano de Fortaleza. 
Com a criação do Plano Nacional de Habitação Popular (PLANHAP), em 1973, persiste-se na continuação de produção periférica de conjuntos nacionais. A escala desses empreendimentos era de verdadeiros bairros, a exemplo do Conjunto Ceará, com 6.582 unidades, e o Prefeito José Walter, com 4.742 unidades.

A solução de grandes conjuntos distanciados dos centros urbanos parece ser a principal resposta para a moradia popular. Esse assunto específico, localização de moradia popular, será mais bem discutido mais adiante, ao se retomar a ação do Estado na promoção de projetos e programas habitacionais. O desequilíbrio entre a alocação da população mais pobre e as regiões dotadas de infraestrutura e serviços é reforçado pelo agravamento da dificuldade de acesso à moradia na Capital. A disputa por terrenos e o acirramento dos problemas habitacionais nos anos de 1980 aprofunda o processo de expandir a habitação popular para espaços ainda mais periféricos em relação ao centro da Cidade.

Há mais de 30 anos, a construção de conjuntos residenciais já ultrapassava os limites de Fortaleza, sendo realocados em outras cidades, principalmente, Caucaia, Maracanaú e Pacatuba. Foi identificado o fato de que foi desde esse momento que foram intensificadas as produções de condomínios populares nas proximidades dos conjuntos habitacionais.

As condições de isolamento da população dos municípios da RMF se tornaram uma circunstância histórica, reforçada pela carência de transportes públicos metropolitanos e pelas dificuldades de mobilidade, que ainda hoje esperam por projetos de modernização ferroviária, com a conclusão de linhas de metrô, entre outros tantos sistemas de integração não aprontados.

Mesmo que em termos de qualidade e desenvolvimento urbano e social essas regiões representassem grande questão a ser resolvida, a incorporação de novas áreas periféricas à RMF se tornava um estímulo econômico. Muitas legislações municipais foram alteradas, ampliando zonas urbanas e possibilitando diversificação de atividades, ainda que suas características permanecessem predominantemente rurais.

Rufino (2012) destaca que a delimitação de áreas urbanas como estratégia de investimento de capitais e de desenvolvimento econômico foi ainda mais evidente no 
litoral, uma vez que conseguia se associar a uma importante atividade para a região - o turismo.

Os investimentos em turismo provocaram significativas mudanças no espaço metropolitano, abrindo espaço para a formação de um forte mercado imobiliário ao final dos anos de 1990. Foram inúmeros investidores que ampliaram redes de hotéis, complexos turísticos e segundas residências que transformaram as características do litoral e desenvolveram uma lógica paralela de urbanização ao se associarem diretamente a capitais externos, fortalecendo a ação imobiliária, sem que se altere assim as condições de infraestruturas tradicionais, que tendem a permanecer estanques e desarticuladas da lógica de crescimento.

A ausência de marcos regulatórios é outra questão a ser destacada, pois, com exceção de Fortaleza, os demais municípios só vieram a constituir seus planos diretores em 2000. Esse crescimento sem regulação, juntamente com a competitividade estabelecida entre municípios representados principalmente pela "guerra de incentivos fiscais", torna a ocupação da região rarefeita e descontínua. 0 mapa apresentado a seguir simula esses avanços sem continuidade e propicia maior percepção dessa realidade.

A leitura da mancha urbana e do avanço da metropolização facilita compreender a efetiva urbanização da RMF, ainda em andamento. Essa dinâmica é revelada pela fraca articulação entre os diversos municípios, em que há a necessidade de entender os movimentos, à medida que eles estão relacionados com expansões capitalistas que trazem inúmeras contradições de desenvolvimento no espaço urbano. 
Mapa 02: Ocupação Espacial da Região Metropolitana de Fortaleza
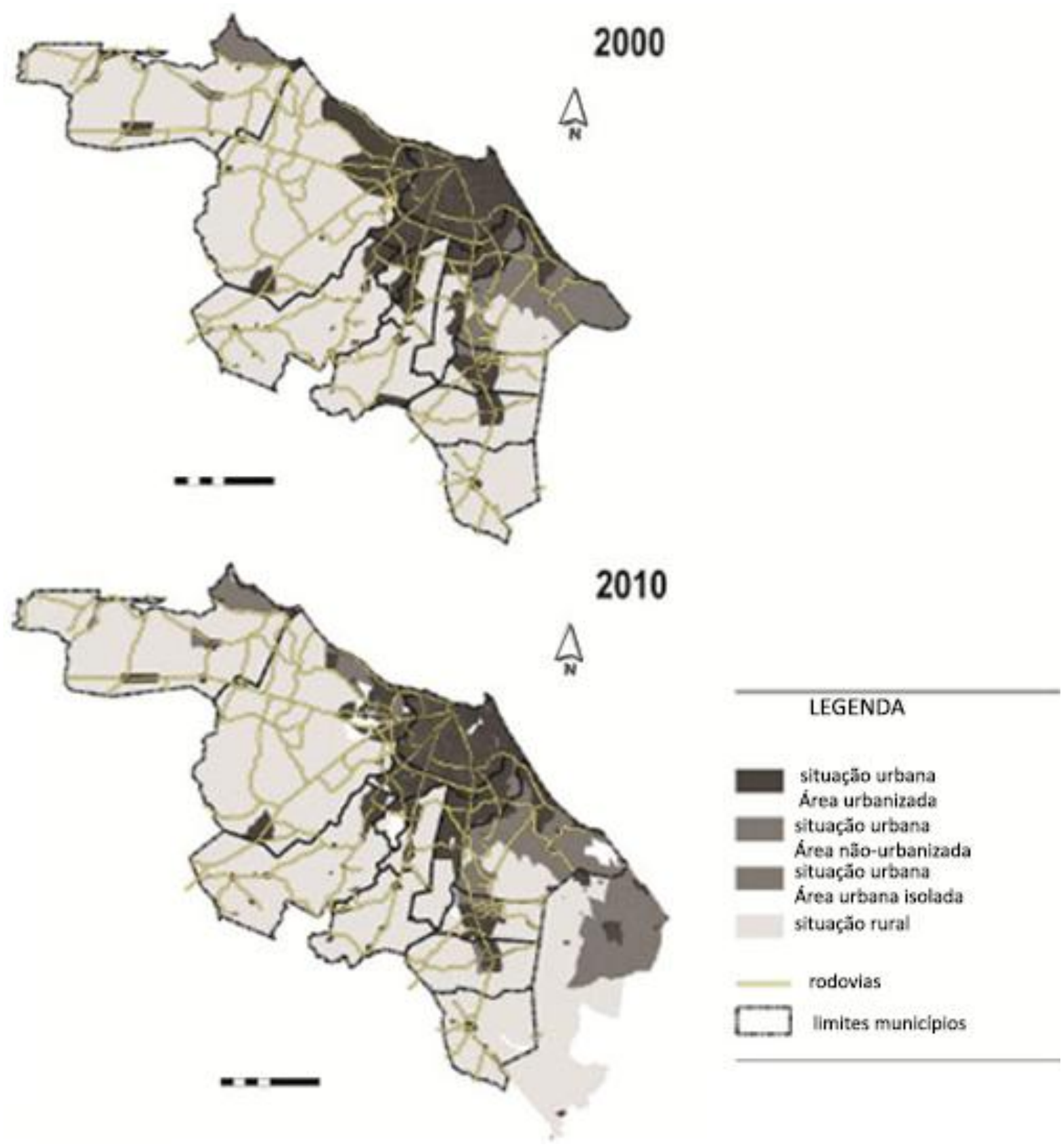

Fonte: Elaboração Clarissa Freitas (2011), base observatório das metrópoles com suporte no censo do IBGE de 2010.

Como fecho da apreensão e da evolução da estrutura da RMF, constata-se que as lógicas de transformações da Metrópole são os fluxos de capitais. Nesse sentido, Santos $(1993)^{30}$, ao estudar a urbanização brasileira, aponta como uma das causas da presença persistente de um modelo geográfico espraiado nas cidades nacionais, com

${ }^{30}$ SANTOS, Milton. Urbanização brasileira. São Paulo: Hucitec, 1993. 
tamanhos desmesurados, feito de especulação e lógica de valorização e apropriação territorial.

No que se refere especificamente ao caso de Fortaleza, a Metrópole parece expandir seus limites, deixando para trás uma considerável quantidade de lotes vagos $^{31}$. A forma como a Cidade se espraia, muitas vezes, segue corredores viários ou se associa a centros de atração de capital. Em uma cidade marcada por essa urbanização, cabe questionar: qual a marca que um programa de investimentos de grandes vultos no capital imobiliário, como o PMCMV, deixaria no tecido urbano? Fortaleza exprime avanços capitalistas do setor imobiliário no território?

Essas perguntas pretendem ser esclarecidas no decorrer desta pesquisa, destacando-se, neste capítulo, no subitem a seguir, as principais tendências de crescimento que os estudiosos do urbano e da economia apontam para a Cidade.

\subsubsection{Tendências no desenvolvimento e expansão da RMF}

Bernal (2004), de maneira simplificada, realça quatros principais tendências e vetores de expansão na RMF. O primeiro, de espacialidade mais antiga, se refere ao polo de Maracanaú, cuja industrialização promovida pela SUDENE, notadamente, com incentivos fiscais, implicou o estabelecimento de distritos industriais associados à fixação da população em conjuntos habitacionais. O segundo materializa-se ao longo do eixo da BR-116, consoante a política de relocalização da indústria iniciada nos anos de 1980, cujo desdobramento encampa os Municípios de Horizonte, Pacajus, Itaitinga e Eusébio.

O terceiro vetor direciona-se para a faixa litorânea oeste, caracterizando-se como um fenômeno diverso e associado à construção de conjuntos habitacionais no Município de Caucaia, com vistas a receber população de baixa renda deslocada da Capital no entorno da BR-020 e, por ser próximo à Fortaleza, atende demanda de espaços de lazer e recreação, tornando-se, desde os anos 1990, pólo de turismo na faixa de praia.

Essas lógicas diversas implicaram a incorporação do litoral de Caucaia à lógica de valorização dos espaços litorâneos pelo veraneio marítimo (PEREIRA, 2006) e pelo

\footnotetext{
${ }^{31}$ Ver tese de Silva (2006).
} 
turismo litorâneo (DANTAS, 2002); sem esquecer, também, sua transformação em área de moradia principal, desde a instalação do Complexo Industrial e Portuário do Pecém, em São Gonçalo do Amarante; além da lógica de reestruturação produtiva do espaço pautado no agronegócio.

O quarto e último vetor aponta para a porção leste da Metrópole, envolvendo os Municípios de Eusébio e Aquiraz, em uma lógica de urbanização litorânea associada ao veraneio marítimo, ao turismo litorâneo e, mais recentemente, ao fenômeno de transformação gradativa destas áreas em locus de primeira residência.

\section{Mapa 03: Vetores de Fortaleza}

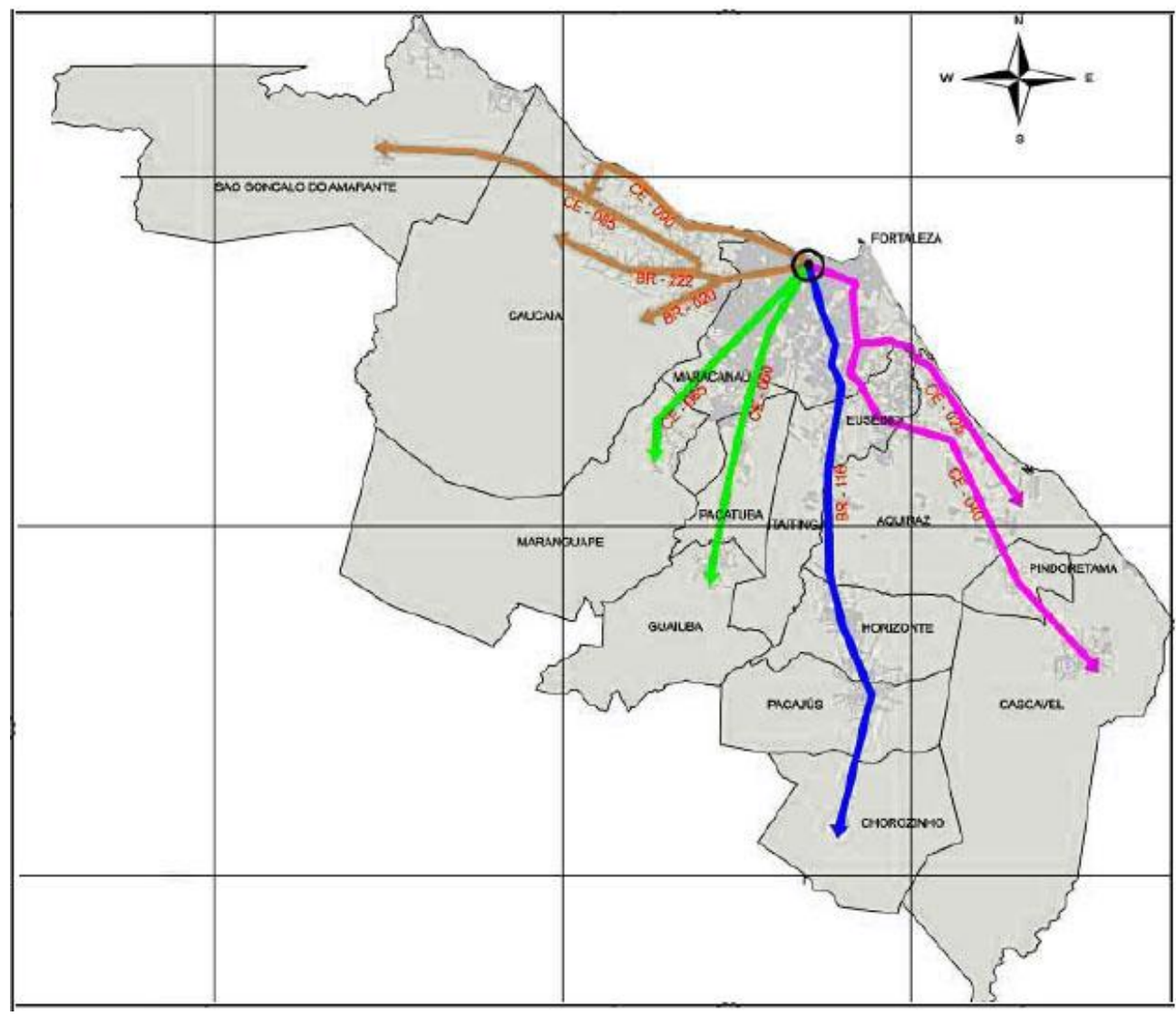

VETOR I

VETOR II

VETOR III

VETOR IV

Fonte: Base CAD, Cleiton Marinho Nogueira (2011) ${ }^{32}$. Edição própria.

Desses vetores, destacam-se três regiões específicas: o núcleo de Fortaleza, Maracanaú e Caucaia, por sua importância para a Metrópole e, também, por interessar à análise desta pesquisa, uma vez que os municípios descritos foram os principais

32 Dissertação de mestrado de Cleiton Marinho Lima Nogueira: Expansão metropolitana e dinâmica imobiliária: o município de Eusébio, 2011. 
focos dos empreendimentos do PMCMV. Dos 139 conjuntos contratados até 2013 na RMF, 114 se reúnem nos três locus especificados.

\subsubsection{O Município de Fortaleza. A concentração urbana e as dinâmicas} socioespaciais.

Conforme visto no item anterior, a RMF é hoje composta por 19 municípios, sendo mais de $70 \%$ de sua população reunida na Capital. A representatividade desta concentração demográfica aufere maior relevância quando considerada a ampla superfície metropolitana diante do intraurbano conturbado e denso que se agrupa em Fortaleza e em alguns municípios fronteiriços, como releva o mapa abaixo.

Mapa 04: Evolução da Mancha Urbana de Fortaleza - Municípios Conurbados
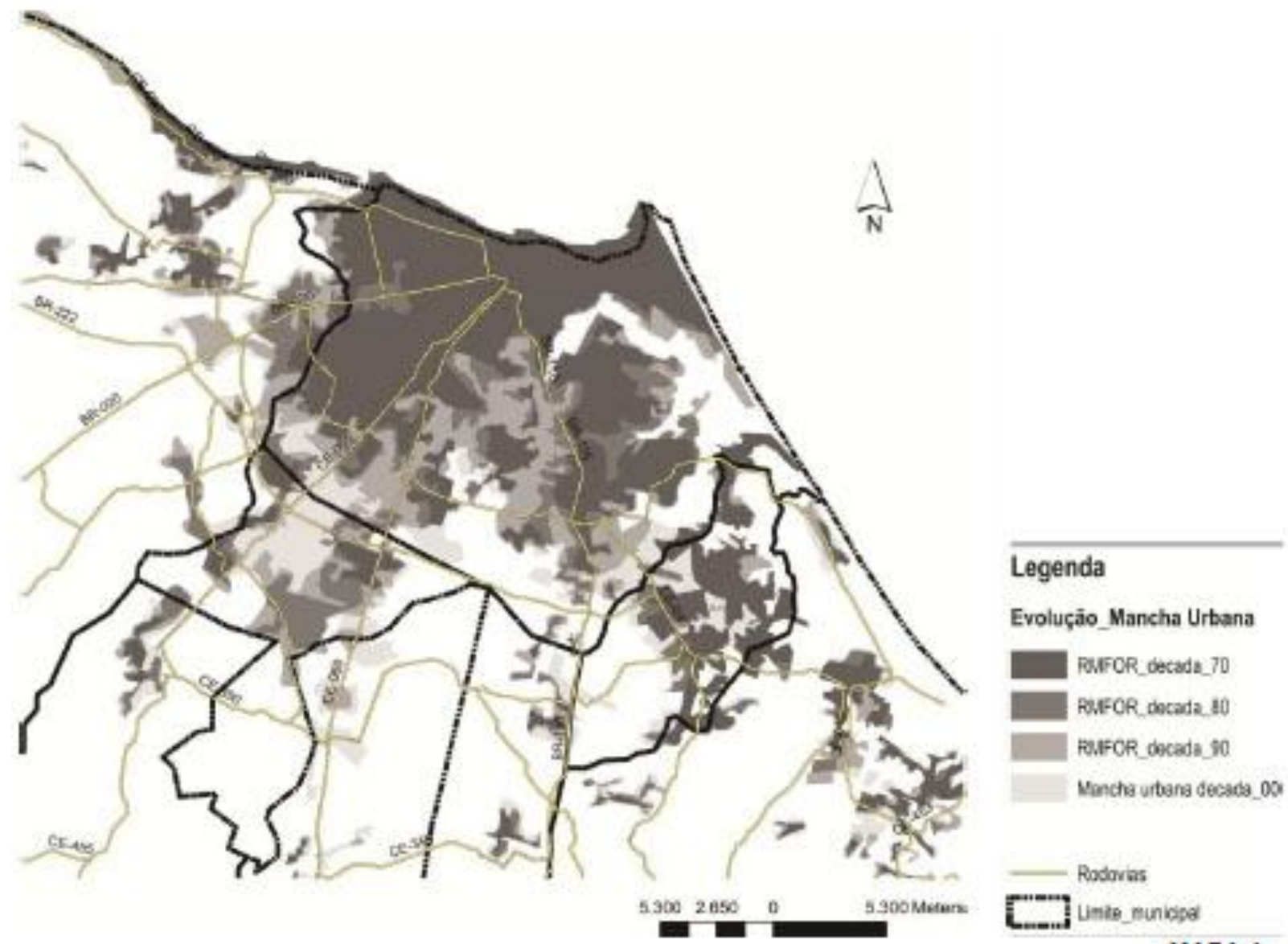

MAPA 4

Fonte: Observatório das Metrópoles - Fotos aéreas sistematizadas por Clarissa Freitas, 
Decorre desse fenômeno a proeminência de compreender a estruturação da Metrópole, a começar pelas alterações ocorridas na distribuição espacial das suas atividades. De 1970 a 2000, a densidade demográfica de Fortaleza mais do que dobrou, saltando de 2.554 para 6.855 habitantes por quilômetro quadrado, consolidando-se como um dos municípios de maior densidade no Brasil. Seu crescimento se acelera tardiamente, comparado com as regiões de industrialização mais antigas.

Foi das décadas de 1970 a 1980 que a Cidade se adensou e as tendências históricas de diferenciação urbanas foram definidas. As distinções entre leste e oeste são plasmadas sobre o espaço pela dicotomia de renda e adensamento demográfico, que assumem esses distintos espaços.

No sentido leste, o crescimento é vertical e horizontal, com grandes empreendimentos privados, shoppings e loteamentos valorizados. Já no sentido oeste, evidencia-se o adensamento com a proliferação de loteamentos populares e conjuntos habitacionais que extrapolam até mesmo o limite da Capital, estendendo-se para os municípios vizinhos as deficiências habitacionais da Metrópole.

Percebe-se uma profunda desigualdade na organização do espaço, onde a noção leste-oeste recebe relevância. A visão dual dessa Metrópole bipartida entre o moderno e o atrasado, o desenvolvido e o empobrecido, é reforçada pela própria política que aqui se desenvolveu no "Governo das Mudanças", que se esforçou por modernizar e desenvolver a Fortaleza, aumentando o conflito e as tensões entre a cidade "moderna" e a "atrasada".

Desde o seu momento mais histórico, essa polarização leste-oeste, embora possa ser vista como um movimento hegemônico na estruturação da Cidade, leva a uma dinâmica de ocupação direcionada às periferias. Quando pensado em escala de região, os assentamentos ao sul respondem às novas lógicas de centralidades de interesse do capital, impulsionando a Metrópole a assumir um retrato morfológico bem mais fragmentado.

Essa polarização claramente tem efeito sobre que tipo de produção de habitação se reproduz em cada uma dessas delimitações. Na verdade, a cidade como base para a atividade imobiliária ocupa um quadrante muito restrito na RMF. A pesquisa de Bernal (2004) apontou que a atuação das grandes empresas da cidade se 
voltava exclusivamente para o mercado de alta renda, e quantifica cerca de $20 \%$ do mercado operante com uma " cesta de produtos" que atende setores mais médios da população de Fortaleza. Com apartamentos mais econômicos e menores, entre a média de 60 e $80 \mathrm{~m}^{2}$. Suas localizações, entretanto, permanecem nas zonas valorizadas da cidade onde existe ampla infraestrutura e os preços dos terrenos desses bairros já saturados, despontam em elevação.

Fortaleza tem um setor imobiliário que por muito tempo se confina em um quadrante bem delimitado pela valorização fundiária e aglutinação de infraestrutura nesses bairros mais centrais. Apesar dessa condição, não significou que o mercado de terras não avançou e loteou a cidade, sobre a base fundiária e a compreensão de que estrutura urbana Fortaleza e a RMF apresenta historicamente, analisamos o subitem abaixo.

À luz dos conceitos que embasam este estudo, entende-se que a produção do espaço construído se fundamenta na diferenciação espacial, pois favorece a valorização e a organização imobiliária da estrutura urbana. A cidade passa a ser um importante setor da reprodução do capital para a atividade imobiliária, sendo um espaço privilegiado de acumulação. Considerando esta perspectiva, é que serão examinados com acuidade a produção e os principais agentes, tarefa que se torna impossível sem antes indagar sobre a base fundiária do território em análise.

\subsubsection{A produção e organização socioespacial de Fortaleza e sua Metrópole}

Consoante Souza (2009), os grandes aglomerados e o processo da diferenciação social em Fortaleza se iniciam em 1930. A ampliação dos assentamentos informais e a expansão da Cidade coincidem justamente com o período de maior crescimento da Capital, duas décadas à frente. A intensificação da urbanização evidencia o avanço das relações capitalistas na produção do espaço, tanto pela mercantilização da terra feito um meio de captação de renda e lucro comercial, quanto pela indústria da construção como produção de mais-valia.

Fortaleza, desde sua efetiva urbanização, exprime modos de produção que avançam na especialização do capital imobiliário, assim como persiste com maneiras "atrasadas" da autoprodução, ou seja, a outra face da cidade baseada estritamente na 
acumulação de capital. Enquanto existir a produção de barracos em territórios informais, coexiste a contratação de casas em terrenos previamente demarcados por um loteador.

Para avançar na compreensão da produção na Metrópole, é crucial entender a consolidação do mercado de terras, que se constitui como condição de partida para o desenvolvimento de toda a atividade imobiliária. Sua importância vai além, uma vez que a terra é vista como circunstância de acumulação, ao mesmo tempo em que denota entraves quando impulsionam jeitos menos avançados de captação de renda sob o ponto de vista de reprodução do capital.

O mercado de terras em Fortaleza começou a se delinear nos anos 1930, concentrando-se, principalmente, nas proximidades do centro da Cidade e na periferia sudoeste. Dois grupos familiares se destacaram entre os detentores dos terrenos - a família Gentil e Manoel Sátiro.

As famílias articulavam tanto capitais bancários quanto comerciais e a capacidade de produzir riqueza com a especulação imobiliária era notória, uma vez que as terras estavam concentradas em poucas famílias proprietárias que conduziam e limitavam a expansão da Cidade. Sobre a família Gentil, Silva (1999) menciona:

A formação do mercado de terras pela família na cidade, concomitante ao comércio, contribui para que não se pense a constituição e transferência de riqueza como momentos separados, ou seja, primeiro deu-se o comércio, em seguida os investimentos na cidade, a partir do sistema de crédito da casa bancária. O lucro subtraído no comércio num processo concomitante foi imobilizado na terra, esta foi ganhando atribuições de reserva de valor. (P.84).

Uma década à frente, em 1940, a implantação de loteamentos se deu dispersamente, diversas direções. Desse tempo é marcado o direcionamento do eixo de valorização da Cidade para o leste e o sudeste. Com o loteamento da Praia do Futuro, propriedade da família Diogo, se efetivou a expansão no sentido leste da Cidade. Sobre essa expansão, Fuck Junior (2002) comenta:

[...] a partir dos anos 1940 aumentou o processo de incorporação de novas áreas a leste da Cidade, realizado por empresários e proprietários fundiários, que se apropriavam de terrenos localizados na periferia urbana, loteando antigos sítios de uso rural, como o Cocó o Alagadiço Novo, o Cambeba, o Estância (Dionísio Torres), o Colosso, o Tunga (na "Água Fria"). Por exemplo, o sítio Cocó, da família Diogo (à margem esquerda do rio), deu origem a um loteamento na Praia do Futuro (na década de 1950), e à Cidade 
2000 (a partir de 1971). Já no lado de Messejana (margem direita do rio), os Srs. Patriolino Ribeiro e Edson Queiroz possuíam terras que se estendiam do rio Cocó ao mar. Ao mesmo tempo, muitos terrenos "centrais" ficavam sem uso, à espera de valorização, demonstrando que a especulação fundiária e imobiliária é também "histórica". (P. 79).

Segundo Santos (2012), as décadas seguintes, com início em 1950, demonstrou grande expansão urbana. O mercado de terras urbanas se ampliou significativamente e o número de loteamentos implantados em 1950 representou quase $30 \%$ dos registrados dos anos de 1930 a 2000.

O capital excedente das oligarquias familiares se associava à atividade imobiliária, e movimentou grandes vultos na compra de propriedades antes rurais, cujos antigos donos eram substituídos por um seleto grupo de empresários. Moreira (2004) comenta sobre as transformações dessa época, em que grandes glebas rurais tinham seu uso redefinido por um pequeno número de agentes.

A transformação de vastas áreas consideradas rurais em zona de expansão urbana como aconteceu em Fortaleza, só é possível com a mudança do valor de uso e de troca da terra que perde sua função de apenas produzir renda para tornar-se mercadoria. $\mathrm{O}$ avanço das relações mercantilistas, marcadas pela própria lógica capitalista sobre as áreas consideradas rurais, permite a superação da oposição clássica entre capital industrial (produção) e a propriedade fundiária (arcaica e impeditiva do crescimento econômico), numa aliança de objetivos, ou seja, acumular capital. (P.35).

A autora sinaliza o fato de que o controle sobre a expansão da Cidade não representava apenas o privilégio sobre a acumulação do capital, mas, também, o aumento do poder e prestígio das oligarquias que possuíam capacidade de influenciar no seu processo político e cultural.

Conforme se constata, nos anos de 1990 a 2000, Fortaleza expressava significativa queda no número de loteamentos implantados, sinalizando que praticamente todo o território do Município já havia sido parcelado. Segundo Rufino (2012), essa racionalidade do parcelamento "precoce" e de grande extensão na Cidade desencadeou intensos processos de retenção de terra, seja pelos loteadores ou pelos compradores que visualizavam a possibilidade de valorização de seus terrenos. 
A intensa captura dos terrenos ainda não loteados e seu parcelamento criou uma condição que, segundo o arquiteto e pesquisador Liberal de Castro ${ }^{33}$, demonstrava uma área loteada para abrigar uma população de dois milhões de pessoas, considerando um adensamento na ordem de 150hab/ha.

Nessa estrutura urbana extremamente oligopolizada, é que Fortaleza passou por sua mais intensa urbanização. O crescimento da população e a falta de acesso a terrenos sedimentaram uma produção bipartida, com arrimo na estrutura da terra, no loteamento para os ricos e loteamento para pobres.

Nota-se, ao mesmo tempo em que se pesa uma profunda proliferação e parcelamento do solo através da incorporação das terras da RMF, expandindo a propriedade privada e redefinindo o uso do solo de forma quase precoce, por outro lado, parece que o mercado imobiliário não ativava esses terrenos. Considera-se que esses movimentos favoreceram uma profunda especulação fundiária e esses vazios e terrenos em estoque fortaleceu a construção de uma cidade excludente, daqueles que não poderiam acessar essa terra. A cidade desigual se afirma com o predomínio de uma grande população empobrecida, produzindo sua casa por meio da autoprodução ou produção "doméstica". Contraditoriamente, o avanço das forças capitalistas no espaço reforçou esse modo de produção na Metrópole.

A compra de loteamentos populares periféricos se tornou importante opção de garantir a propriedade privada ao trabalhador assalariado. Por outro lado, a ocupação de terras públicas não ocupadas e terrenos em áreas de risco se tornaram opção para o contingente mais empobrecido improvisar sua moradia. A favelização se tornou efetivamente um "problema urbano" para Fortaleza nos anos 1970, quando o Estado apontou ações mais concretas.

No momento em que a habitação se consolidou como um problema urbano para a RMF percebe-se a aproximação da política de habitação à de desenvolvimento urbano. A necessidade de uma política voltada para o espaço urbano tem na política habitacional sua principal base.

Tal ação se justifica mediante a imensa relevância que a problemática habitacional aufere, à medida que a expansão das periferias, carentes dos serviços de

\footnotetext{
33 "Fortaleza, então com 520 mil habitantes" em CASTRO, 1977 apud RUFINO 201, p.112.
} 
infraestrutura e habitabilidade, tornava-se a tônica da urbanização no contexto de todo o País. O Estado tem importante papel estruturador do espaço. Em Fortaleza, a política habitacional constituíra-se em um dos pilares da reorganização espacial.

Consoante constatou Rérisson (2013), a atuação do Poder Público, no plano municipal, no setor habitacional de Fortaleza, está representada no primeiro momento nas obras realizadas pela Fundação de Serviço Social de Fortaleza (FSSF). No período de 1969 a 1978, a FSSF construiu três conjuntos habitacionais, totalizando 2322 unidades habitacionais associadas diretamente aos programas de desfavelamento.

Outra ação do Poder Público, na contextura, no início dos anos de 1980, é a criação da PROAFA - Fundação Programa de Assistência às Favelas da Região Metropolitana de Fortaleza, que executava intervenções de erradicação de favelas em áreas de risco para unidades habitacionais construídas em terrenos adjacentes ao local de origem da população.

Apesar de os conjuntos resultantes dessas ações mostrarem localização das unidades nos próprios locais das favelas que eram reassentadas, havia um indicativo da lógica de produção em grande quantidade e, na maioria das vezes, em localização periférica, como aconteceu com o Conjunto Marechal Rondon, implantado no limite sudoeste de Fortaleza, já próximo ao município de Caucaia.

A atuação do Poder Público no setor habitacional, nesse período, está associada à produção de construção de grandes conjuntos habitacionais para a população de baixa renda, não necessariamente proveniente de favelas. Essa ação era executada principalmente pela $C O H A B-C E$, órgão estadual e agente vinculado ao $\mathrm{SFH} / \mathrm{BNH}$; e os conjuntos habitacionais eram distribuídos espacialmente na periferia, ocupando grandes glebas onde o valor da terra era significamente menor.

A grandeza dessa produção habitacional pode ser observada ao se tomar a quantidade de unidades habitacionais dos nove maiores conjuntos. Esse número corresponde a quase 40 mil domicílios ${ }^{34}$, conforme sinaliza a tabela a seguir.

\footnotetext{
${ }^{34}$ Ver tese de doutorado de Rérisson (2013) " Moradia, arquitetura e cidade: mudanças e permanências na produção da habitação social no espaço urbano metropolitano de Fortaleza".
} 
Tabela 03: Maiores conjuntos produzidos pelo BNH em Fortaleza

\begin{tabular}{cccc}
\hline CONJUNTO & MUNICiPIO & TOTAL DE UH'S & CONCLUSÃo \\
\hline José Walter & Fortaleza & 4774 & 1973 \\
\hline Acaracuzinho & Maracanaú & 1976 & 1976 \\
\hline Ceará & Fortaleza & 8669 & $1977-1981^{*}$ \\
\hline Industrial & Maracanaú & 1276 & 1979 \\
\hline Esperança & Fortaleza & 2039 & 1981 \\
\hline Jereissati & Maracanaú & 11334 & $1984-1987^{*}$ \\
\hline Planalto Caucaia & Caucaia & 1264 & 1984 \\
\hline Araturi & Caucaia & 2230 & 1985 -1989* \\
\hline Nova Metrópole & Caucaia & 5537 & \\
\hline * Conjuntos habitacionais construidos em diferentes etapas, identificando datas de entrega da primeira e última.
\end{tabular}

Fonte: Rérisson (2013).

Seguidos da Capital, os municípios da RMF que concentram o maior número de conjuntos habitacionais são Caucaia e Maracanaú, este último, justamente, escolhido para a implantação do Distrito Industrial. Naquele período, a população de Maracanaú mais do que duplicou, passando de 15.685 em 1970 para 37.834 habitantes em 1980, e a de Caucaia registrou um crescimento de $72 \%$ na mesma década, aumentando de 54.754 para 84.108 habitantes. (GONDIM, 1987).

Com o rompimento das atividades do $\mathrm{BNH}$ e o fechamento da atuação das CoHabs nas décadas seguintes, percebe-se grande recuo na produção habitacional pelo Estado. Nos anos 1990 as implantações de pequenos conjuntos associados a projetos de urbanização de favelas tornou-se a regra. Segundo Pequeno e Elias (2014), essa fase marcou a redução do papel do Governo Estadual na produção habitacional; a chegada das ONGs como articuladoras dos movimentos sociais; a delegação de responsabilidades ao município por meio da Constituição Federal de 1988, o qual não exibia condições estruturais condizentes com o seu novo papel.

Só em meados dos anos 2000, a produção habitacional de interesse social em Fortaleza se reorientou e conseguiu ter distintos focos. Esse fato decorre, principalmente, da criação da Fundação de Habitação Popular de Fortaleza (Habitafor), Pequeno e Elias (2014) realça o fato de que a Habitafor concentra esforços em áreas de risco, urbanização de favelas vinculadas a projetos de mobilidade urbana e provisão habitacional. Destaca, ainda, que sua produção voltada para as famílias reassentadas eram em vazios próximos às antigas moradias, diferenciando-se de modelos que 
amplamente promoviam a periferização da habitação social. O mapa, a seguir, sistematizado por Aragão (2010), revela a produção estatal na RMF.

Mapa 05: Evolução da produção habitacional promovida pelo Estado
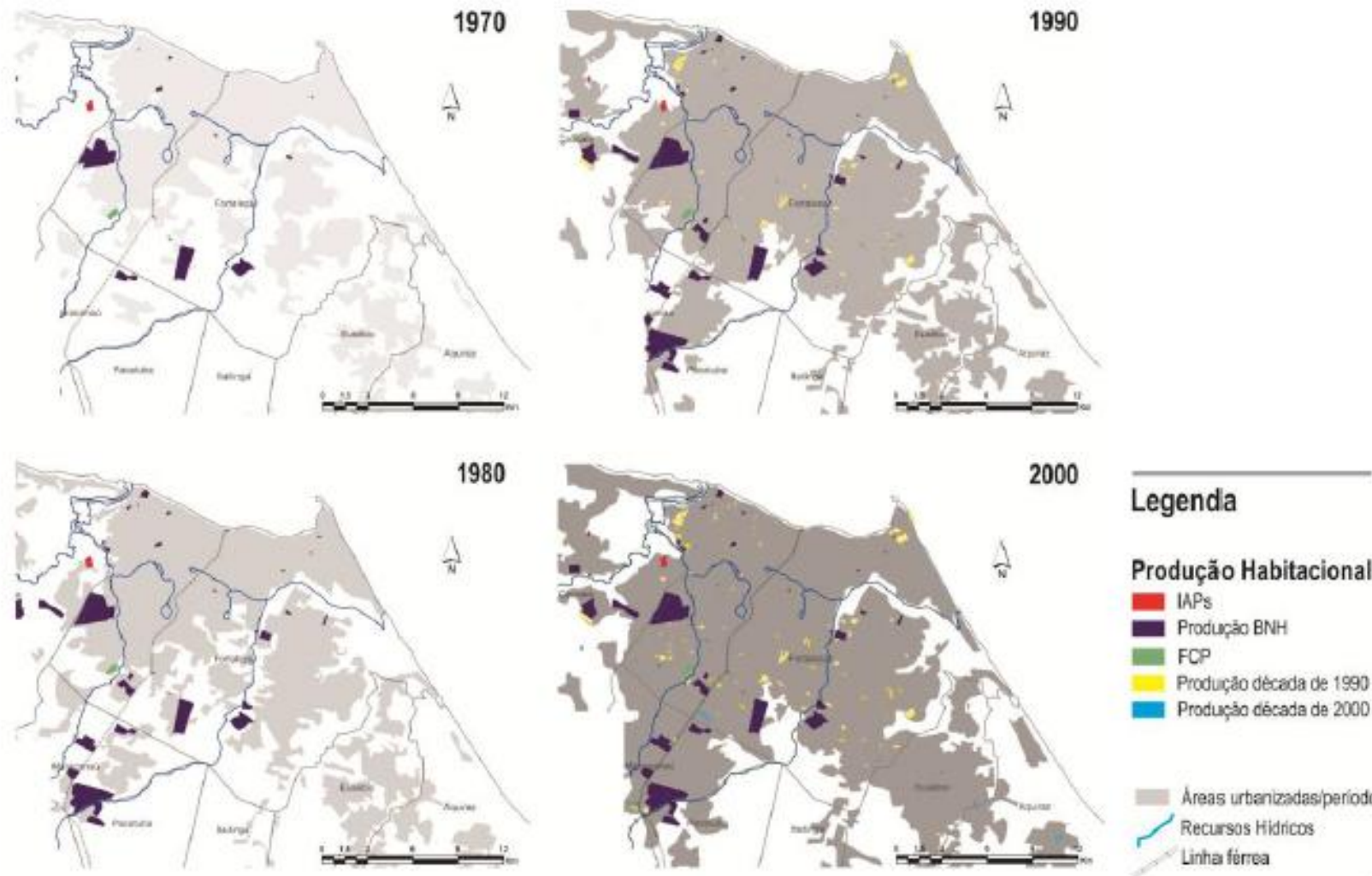

Produçăo Habitacional

- IAPs

- Produpáa BNH

FCP

Produça década de 1990

- Produç̧óc cécada de 2000

Fonte: Base Geometropolis - Observatório das Metrópoles / Fotos aéreas.

Sistematizado por ARAGÃO (2010).

Ao sintetizar a produção estatal na RMF, o mapa mostra com maior acuidade os grandes conjuntos habitacionais (assinalados em roxo), eles correspondem aos grandes empreendimentos do $\mathrm{BNH}$, em que permanecem no limite da zona urbana. Revela como a metropolização e a ampliação da mancha urbana coincidem com a produção habitacional dessa época.

As políticas habitacionais pós-2000 se iniciam com aportes federais junto ao Programa Habitar-Brasil e, posteriormente, passam a contar com financiamento de vários programas do Ministério das Cidades que abrem diversas frentes de intervenções com uma produção mais fragmentada na realização de pequenos 
conjuntos residenciais, tentando utilizar terrenos remanescentes, conforme assinalado no mapa acima.

Atualmente a Região Metropolitana de Fortaleza (RMF) é constituída de 19 municípios, sendo sua população estimada em aproximadamente quatro milhões de habitantes. Grande parte dela se encontra em municípios conurbados a Fortaleza: Maracanaú, Itaitinga e Pacatuba, ao sul, Aquiraz e Eusébio, ao leste, e Caucaia ao oeste, que totalizam cerca de $85 \%$ da população metropolitana.

Ainda que de forma segmentada, os governos municipais têm papéis importantes na configuração do PMCMV, pois, é no município que deveriam ser definidos os recortes espaciais, tendo em vista a localização em termos de planejamento urbano e do uso dos instrumentos da política urbana, bem como das atribuições que eles devem desempenhar em termos de formulação da demanda para a faixa 1, definição de critérios, termos de compromisso para realização de infraestrutura e acompanhamento da gestão do trabalho social.

Ainda a respeito do Setor Estatal, observou-se que a produção do PMCMV se distribui de maneira diferenciada entre os municípios da RMF. Dentre os pertencentes a essa região, percebeu-se que aqueles que concentraram o maior número de empreendimentos foram, justamente, os mais populosos, onde se agrupa a maior parte da demanda e do défice habitacional - Fortaleza, Caucaia e Maracanaú - que passam a ser priorizados neste estudo.

A atividade das prefeituras em relação aos produtos comercializáveis do PMCMV, ou seja, as faixas 2 e 3, não é orientada pelo desenho do Programa e, na prática, também não acontece semelhante à produção de qualquer empreendimento. As faixas 2 e 3 ficam sob a responsabilidade da iniciativa privada, mediada pela CEF.

O governo estadual e os municipais da RMF, ao longo da primeira fase do PMCMV, apresentam esforços concentrados no reassentamento associado à remoção de áreas de risco e obras viárias por meio do PAC urbanização. Na segunda etapa do Programa, foca-se em adoção de medidas para reassentamento de comunidades removidas em decorrência das obras para a Copa do Mundo, vinculadas à mobilidade urbana e ao turismo. No caso de projetos relacionados a reassentamentos de interesse da gestão municipal de resolução passiva de antigas ocupações, as prefeituras 
realizavam doações de terrenos, assim como oferecia contrapartida de serviços e infraestrutura urbana para esses grandes projetos.

O arcabouço institucional de cada um desses três municípios é diverso, e a própria diferença sobre o interesse dos municípios por investir no Programa enseja vários resultados, como destacam Pequeno e Vieira (2015). Em sua pesquisa, exprime que Caucaia, segundo maior município do Estado, com 353 mil habitantes, o PMCMV encontra-se em uma coordenadoria especial vinculada ao Gabinete do Vice-Prefeito e conta com a participação de técnicos das Secretarias de Planejamento Urbano e de Ação Social. Vale mencionar, todavia, a fragilidade institucional reconhecida no porte da equipe, nas condições de acesso aos dados e na necessidade de contratação de serviços técnicos a terceiros para a realização dos instrumentos da política urbana e habitacional, os quais tendem a ser subutilizados.

O autor citado aponta ainda alguns dados que podem explicar a grande expansão do PMCMV nesse Município: a agilidade na formulação de cadastro de demandas, a facilidade na obtenção de terrenos, os quais tinham na orientação da política municipal o sentido de contratar obras e mostrar resultados e compromisso na sua realização, ainda que não fossem dotados de infraestrutura.

Maracanaú corresponde ao terceiro maior município da RMF com cerca 221 mil habitantes, tendo no setor industrial sua principal atividade econômica. Em suas pesquisas, Pequeno e Vieira (2016) identificam, nesse município, uma situação bastante diferenciada em termos da gestão. Revelou-se que apresentava uma associação entre o planejamento e o controle urbano, produzindo estudos de viabilidade para os novos empreendimentos a serem inseridos na região, considerando limites impostos pela legislação urbanística. Além disso, a disponibilidade de bases de dados, o geo-referenciamento das informações e a sua aplicação para o controle e a gestão do solo urbano trazem ao Município um diferencial se comparado aos demais. Por outro lado, no referente aos projetos de habitação popular de mercado, verifica-se a falta de articulação e o esforço do Município em buscar as garantias de melhores condições de implantação para muitos empreendimentos em curso.

Detendo-se nesses três municípios, passa-se agora a detalhar cada um deles, iniciando por Maracanaú, que se apresenta como aquele com o mais alto nível de integração relativamente ao centro disseminador, Fortaleza. Esta posição se justifica 
pela fundação do Distrito Industrial nos idos dos anos 1980, seguido da construção de conjuntos habitacionais pensados para abrigar a população de trabalhadores da indústria implantada.

A demanda e o défice habitacional do núcleo de Fortaleza, entretanto, impôs a transferência de sua população para Maracanaú em níveis mais importantes do que sua vocação original. O pólo industrial que motivou sua criação introduziu movimentos pendulares representativos do aumento gradativo da integração do município à malha urbana.

O dinamismo de Maracanaú é expresso em posição destacada em distintos indicadores: em 2003, segundo lugar no total de operações bancárias-financeiras (R\$ 124.841.728,78 contra $\mathrm{R} \$ 11.432 .383 .795,63$ de Fortaleza); em 2002, no total de empregos formais em atividades "de ponta" (1.640 contra 17.342 de Fortaleza) só perdendo, em 2000, para Fortaleza e Caucaia no quesito massa de rendimento mensal ( $R \$ 23.322 .024$ contra $R \$ 32.369 .401$ de Caucaia e $R \$ 656.767 .993$ de Fortaleza). Tal dado é reforçado com sua inclusão como segundo PIB mais importante (R\$ 1.797.798,00), correspondendo a $10,14 \%$ do PIB total do espaço urbano.

Estes dados apontam intensiva forte tendência de desconcentração do crescimento da Metrópole. O avanço da atividade turística tende a contribuir com a expansão territorial da Metrópole por meio do litoral leste, tendo Aquiraz como principal pólo e, ao oeste todo, a "costa do sol poente", desde Caucaia. Os municípios de vocação industrial, como Eusébio, Horizonte, Pacajus e Maracanaú, sobressaem-se com os mais elevados valores do PIB. Nessa perspectiva, pode-se observar tendência de desconcentração da atividade econômica do núcleo da Metrópole em direção aos outros municípios integrantes da RM, principalmente para aqueles onde se localizam os grandes investimentos industriais e turísticos.

Caucaia se destaca, grosso modo, em virtude de duas variáveis distintas: uma é resultante da política de construção de conjuntos habitacionais e outra é associada à valorização dos espaços litorâneos pelo lazer, recreação, veraneio e turismo.

Neste Município, o antigo BNH, nos anos de 1980, empreendera a lógica de construção de conjuntos habitacionais para responder ao défice habitacional notado em Fortaleza. Tal racionalidade tem implicações diretas no aumento do seu 
contingente populacional, atingindo, atualmente, a segunda população do Estado, estimada em 294.284 mil habitantes no ano 2004.

A política iniciada no final dos anos 1980 e início dos 1990 reforçou a constituição das zonas de praia de Caucaia em espaços privilegiados do veraneio e do turismo. Nos últimos anos, esse dado começou a mudar de tônica com a indicação da lógica de transformação de antigos espaços de veraneio em locus de primeira residência, consequentemente aumentando o fluxo entre o Município e o Pólo.

Esses desdobramentos incidem em indicadores tais como: total de operações bancárias-financeiras (2003), ocupando a terceira classificação ( $R \$ 60.968 .260,06$ ); massa de rendimento mensal (2000), ocupando a segunda posição (R\$ 32.369.401), ultrapassando Maracanaú (R\$2 23.322.024); total de empregos formais e atividades de ponta, na quinta posição (537), perdendo para municípios como Maracanaú (1.640), Eusébio (857) e Aquiraz (571); concentra a terceira maior massa do PIB na Metrópole ( $R \$ 852.846$ contra $R \$ 1.797 .798$ de Maracanaú e $R \$ 12.884 .125$ de Fortaleza), correspondendo a $4,81 \%$ do PIB total do espaço urbano.

Por fim, Fortaleza, centro irradiador e concentrador de grande parte do PIB da região, sendo que os movimentos intraurbanos e as condições de acesso passam necessariamente pelas condições de ligações com esse núcleo. É desse núcleo urbano que os demais municípios se desenvolvem, e dada a sua grande importância é que sua descrição será feita em um subitem separado de sua região metropolitana. É com base na caracterização do Município de Fortaleza que muitos sentidos podem ser traçados a respeito do delineamento dos agentes atuantes junto ao PMCMV.

\subsection{Programa Minha Casa Minha Vida: Os agentes envolvidos}

Considerar o papel dos agentes, notadamente, das práticas dos setores empresariais imobiliários e da construção civil, das ações do Estado nas diferentes esferas de governo e dos conteúdos dos instrumentos de planejamento e gestão do solo urbano e habitacional na RMF é uma tarefa por demais extensa para uma dissertação.

Para tornar essa tarefa possível, no entanto, e apreender essa realidade, é importante reunir o quadro dos agentes envolvidos e aprofundar o estudo da 
organização do setor imobiliário junto ao PMCMV. Uma vez que as dinâmicas e as ações do setor empresarial na implementação do PMCMV não são isoladas, se faz necessário compreender esse quadro, para, por fim, iluminar as escolhas espaciais advindas dessas relações.

Este capítulo tem como proposta, portanto, caracterizar os agentes inventariados pela legislação do PMCMV, apresentando os agentes sociais envolvidos na implementação do Programa no contexto da RMF, dando enfoque ao setor empresarial, sobretudo, como ele se estruturava no momento anterior ao lançamento do Programa.

De início, é relevante ressaltar o que PMCMV define como principais agentes dessa política habitacional, pensando o grande espectro de agentes que, se não atuam diretamente, fazem parte da política, com reivindicações, pressões e demandas a serem ouvidas. Para isso, o quadro elaborado por Loureiro, Macário e Guerra (2013), mostrado a seguir, poderá sintetizar a ampla diversidade desses agentes, que, em certo grau, influenciam e realizam ações para a concretização do PMCMV.

Quadro 07: Agentes e grau de influência no desenho da política habitacional

\begin{tabular}{|c|c|}
\hline Estado: políticos e burocratas & Sociedade civil organizada \\
\hline $\begin{array}{l}\text { 1. Presidência da República (Casa Civil) e Ministério da Fazenda, tendo } \\
\text { como principal preocupação ativar demanda em contexto de crise } \\
\text { econômica (núcleo decisório). } \\
\text { 2. Ministério das Cidades (equipe técnica do SNH, orientada pelo ideário } \\
\text { da reforma urbana): preocupação social de redução do déficit habitacional, } \\
\text { especialmente para a população de baixa renda (participante do núcleo } \\
\text { decisório, com influência importante por meio da incorporação de } \\
\text { segmentos de baixa renda entre beneficiários do programa). }\end{array}$ & $\begin{array}{l}\text { 1. Empresariado da construção civil e do setor imobiliário: recuperar } \\
\text { investimentos prévios e dinamizar mercado imobiliário (forte influência). } \\
\text { 2. CRECISP (sem influência, com a tentativa frustrada de incorporar ao } \\
\text { programa a recuperação de moradias já existentes). } \\
\text { 3. Representantes de organizações sociais no Conselho Nacional das } \\
\text { Cidades e no Conselho Gestor do FNHIS (influência pontual, reforçando } \\
\text { políticas mais amplas do desenvolvimento urbano, como saneamento, } \\
\text { transportes etc.). }\end{array}$ \\
\hline $\begin{array}{l}\text { 3. Representantes estatais no Conselho das Cidades e no Conselho Gestor } \\
\text { do FNHIS (influência pontual, reforçando políticas mais amplas do } \\
\text { desenvolvimento urbano, como saneamento, transportes etc). }\end{array}$ & $\begin{array}{l}\text { 4. Movimentos sociais pró-moradia (sem influência, com a tentativa } \\
\text { frustrada de incorporar ao programa a recuperação de moradias já } \\
\text { existentes). }\end{array}$ \\
\hline $\begin{array}{l}\text { 4. MPOG (monitoramento do programa junto com Casa Civil e SNH). } \\
\text { 5. Congresso Nacional, PMDB (influência pontual, com a incorporação de } \\
\text { pequenos municípios ao programa). } \\
\text { 6. CAIXA, órgão executor das operaçôes financeiras (influência } \\
\text { importante na definiçãao de critérios técnicos e avaliação de projetos). }\end{array}$ & $\begin{array}{l}\text { 5. Entidades municipalistas (influência pontual, com a incorporação de } \\
\text { pequenos municípios ao programa). } \\
\text { 6. Grupos financeiros ligados ao Programa de Subsídio à Habitação (PSH) } \\
\text { (influência pontual, com a incorporação de pequenos municípios ao } \\
\text { programa). }\end{array}$ \\
\hline $\begin{array}{l}\text { 7. Prefeituras, coparticipantes, em ações complementares na área de } \\
\text { infraestrutura urbana. } \\
\text { 8. Orgãos de controle: TCU e CGU (influência pontual). } \\
\text { 9. CGPAC, GEPAC e salas de situação (influência importante na gestão e } \\
\text { monitoramento). }\end{array}$ & $\begin{array}{l}\text { 7. Entidades profissionais de arquitetos e engenheiros e especialistas } \\
\text { em áreas habitacionais e questões urbanas - críticas que levaram à } \\
\text { redefinição do desenho do programa (influência pontual). }\end{array}$ \\
\hline
\end{tabular}

Fonte: Loureiro, Macário e Guerra (2013).

Ao reunir os agentes, Loureiro, Macário e Guerra (2013) mostram a grande abrangência que o PMCMV possui, contudo, faz parte da sua delimitação e execução 
apenas reduzida parcela. Os principais agentes envolvidos na produção do Programa foram definidos, principalmente, em dois tipos fundamentais: aqueles que se incluem no setor empresarial e, contratando empreendimentos, são responsáveis pela incorporação, construção e comercialização das unidades; e os diretamente associados ao Estado, os que assumem tarefas de planejamento, aprovação e gestão do Programa.

Esta investigação concentra atenção na indicação dos agentes que influenciam diretamente na implementação do Programa, dando ênfase ao entendimento do agente imobiliário que, como mencionado, é chave fundamental de compreensão por meio da qual esta pesquisa se estrutura. Esse segmento integra um grupo de agentes envolvidos bem distintos, em que participam interesses e grupos diversos; são eles os proprietários fundiários, corretores, incorporadores e empresas da construção civil.

\subsubsection{O setor privado e a organização do mercado imobiliário}

Distinguindo, inicialmente, os agentes ligados ao setor empresarial, percebe-se que o PMCMC trouxe novos elementos para análise da produção habitacional. Sua diversidade amplia-se não apenas ao público beneficiário a que se destina, mas, também, em relação aos setores que podem contratar empreendimentos, sendo este setor - o empresarial - um elemento-chave para essa produção. É essa percepção que dá relevância a este estudo, quando observa que é o agente privado, engrandecido pelo Programa, que assume centralidade nas escolhas da produção habitacional financiada pelo Estado.

Para iniciar a discussão deste tema, é importante exprimir a noção de que o agente privado está imerso em um setor complexo - o setor imobiliário - caracterizado pela articulação de práticas realizadas por distintos agentes. Desse modo, quando se utiliza, genericamente, a expressão setor imobiliário, deve-se atentar para o fato de que reúne estratégias empreendidas por agentes que podem ser distintos, mesmo que seus objetivos sejam convergentes; por agentes que podem atuar em parcerias; por grupos que disputam entre si, mas, que, também, se unem por meio de interesses em comum. 
Há inúmeras análises que procuram caracterizar os agentes que participam da produção do espaço. Harvey (1982) os categoriza em facções de capitais: os que procuram a apropriação de renda (proprietário de terra, empresas imobiliárias, intermediários financeiros etc.); os que irão lucrar com a produção por via da construção (empresas construtoras); o capital que enxerga no ambiente construído uma possibilidade de investir riqueza excedente, assim como a força de trabalho que se utiliza do ambiente construído para seu consumo e reprodução.

Esse esquema de agrupar os agentes segundo a origem do lucro e o tipo de atividade investida é bastante explicativo para entender todo o ciclo de produção capitalista da moradia. Se, em um extremo, ao final da produção, se encontram os agentes envolvidos com a circulação de imóveis e edificações que estão associadas aos lucros de comercialização, no extremo oposto, na origem do ciclo, há o proprietário de terra, que, embora não participe necessariamente do ciclo, detém o monopólio do insumo fundiário e sua renda advém da especificidade da renda fundiária.

Ainda nesse processo existem os construtores de edificações urbanas, cuja natureza de sua atividade é industrial e produtiva, uma vez que transformam insumos e força de trabalho em uma mercadoria final. O lucro, aqui, é de natureza industrial, embora tenha profunda ligação com a terra urbana. É necessário ressaltar o papel fundamental na articulação entre esses agentes, e quem cumpre essa função é o incorporador. Sua atividade está centrada na elaboração do projeto do empreendimento, na definição e coordenação do produto imobiliário. Seu lucro não advém apenas da comercialização. De acordo com uma leitura marxista, ele é mais complexo, pois se baseia no sobrelucro final fundiário obtido desde a produção da localização urbana do empreendimento.

Pelas regras do jogo da produção no PMCMV, foi visto que as condições dadas são diferentes do "livre mercado". São estabelecidos tetos e valores da habitação e as condições mínimas para o terreno, assim como a avaliação e a aprovação de critérios do financiamento por um órgão financiador. Mesmo na produção para a faixa 1 , em que a etapa de comercialização não existe, alocam-se outras atratividades que requerem diferentes estratégias para os investidores e empresários do setor imobiliário. O PMCMV se coloca como um programa que traz atrativos para um grande número de empresas, denotando vários portes, origens, nichos de mercado, 
estratégias de parcerias e subcontratações, além de ampla abrangência regional ou nacional.

Nesse sentido, é importante compreender o quadro da organização desse setor em Fortaleza, quem são os agentes atuantes, quais as características emergentes que podem surgir do mercado imobiliário local. Essa investigação tenta captar características que emergem de uma condição local, e, quem sabe, sejam particulares de Fortaleza e podem interferir no desdobramento do PMCMV, bem como a própria repercussão que um programa dessa dimensão tem sobre o desenvolvimento urbano.

Uma vez em que se busca mostrar, neste capítulo, que as políticas públicas parecem ser definidas na esfera da produção e nas articulações entre os diversos agentes imobiliários, começa-se a descrever os arranjos produtivos institucionais do setor privado que, envolvido com a produção habitacional por meio do PMCMV, mostrará grande variação dos agentes envolvidos, bastantes heterogêneos em sua composição e na aproximação junto ao Programa, sendo essa, talvez, a principal característica do PMCMV em Fortaleza. Essa percepção se contrasta com a sua produção que seguiu projetos únicos e formas semelhantes de responder arquitetonicamente a moradia popular.

Tradicionalmente, o setor imobiliário na Capital do Ceará é compreendido por uma pulverização da produção em um grande número de empresas de pequeno e médio porte. Rufino (2012) ressalta que esse fato é dado como marca estrutural do setor imobiliário nesta Cidade, característica apontada como razão que dificulta a concentração de capital no setor.

Sabe-se que, na atividade imobiliária, além da rentabilização do capitaltrabalho na produção da construção, há os lucros advindos dos sobrelucros da valorização, rendas associadas à estrutura fundiária. A terra, apesar de ser uma barreira e de deduzir das taxas de lucro a transferência do preço de seu insumo, é, também, objeto de valorização e lugar para a reprodução do capital. E, uma vez que os ganhos não advêm somente da atividade produtiva, o apelo para a racionalidade e gestão da indústria da construção é afetado.

Esse pensamento se desdobra em certa dificuldade de implementar inovações técnicas e de investimentos na mecanização, uma vez que parece apostar em soluções de baixo investimento de capital na produção imobiliária. Essa é a maneira mais 
comum de se aproximar e perceber o mercado imobiliário de Fortaleza. Ao cuidar de concepções já estabelecidas acerca do mercado imobiliário local, ressalta-se que a repetição dessa circunstância comum pode encobrir feições particulares da organização do setor imobiliário na RMF e que são reveladas nas relações entre seus principais e diversos agentes.

Questiona-se, nesse momento, como se articulava o mercado imobiliário no preâmbulo do lançamento do Programa Minha Casa Minha Vida. Quais as características particulares? Como se reorganiza com a entrada de um amplo financiamento federal e com a movimentação de grandes construtoras nacionais? Porquanto se pressupõe que as políticas habitacionais são também reguladas pelas práticas do mercado imobiliário e fogem do arcabouço institucional do Estado, esse é um assunto de suma importância para esta pesquisa. Nesse sentido, é relevante investigar os antecedentes do PMCMV, entendendo qual a oferta de produtos e quais os agentes que atuavam na produção desse mercado habitacional.

Quase uma década antes do lançamento do PMCMV, em 2001, Bernal (2004) realizou pesquisa com mais de 11 empresas do setor imobiliário de Fortaleza e constatou que, destas, dez desempenhavam funções de incorporação e construção e apenas uma atuava exclusivamente no ramo da construção. A autora destaca, ainda, que esse direcionamento se justificava, pois operava com uma incorporadora pertencente ao mesmo grupo familiar. O dado mais relevante da pesquisa citada, de interesse desta investigação, é que nenhuma das empresas apontadas relatou atuar com fontes de financiamento, sendo o capital próprio sua feição de iniciar a produção. 
Tabela 01: As Onze maiores incorporadoras atuantes em Fortaleza em 2002

\begin{tabular}{|c|c|c|c|c|c|}
\hline EMPRESA & $\begin{array}{c}\text { CAP } \\
\text { SOCIAL }\end{array}$ & $\begin{array}{c}\text { CAP } \\
\text { IMOB }\end{array}$ & $\begin{array}{c}\text { ORIGEM } \\
\text { CAPITAL }\end{array}$ & FINANCIAMENTO & EMPREGADOS \\
\hline IDIBRA & 229.00 & 19.000 & LOCAL & PRÓPRIO & 120 \\
MARQUISE & 58.267 & 5.320 & LOCAL & PRÓPRIO & 225 \\
LM & 12.000 & 40.000 & LOCAL & PRÓPRIO & 24 \\
COLMÉIA & 10.300 & 1.635 & NACIONAL & PRÓPRIO & 500 \\
ENGEXATA & 6.500 & 4.500 & LOCAL & PRÓPRIO/BID & 300 \\
N.S. FÁTIMA & 6000 & 1.600 & LOCAL & PRÓPRIO & 410 \\
MOTA MACHADO & 5463 & 6.728 & LOCAL & PRÓPRIO & 120 \\
MARTE & 4000 & 20.000 & LOCAL & PRÓPRIO & 100 \\
DIAGONAL & 1000 & 300 & LOCAL & PRÓPRIO & 300 \\
BLOKUS & 560 & 244 & LOCAL & PRÓPRIO & 100 \\
POTENZA & 500 & 5.000 & LOCAL & PRÓPRIO & 100 \\
\hline
\end{tabular}

Fonte: Dados adquiridos em Bernal(2004), digitalização própria.

O grande espectro das empresas atuantes nesse mercado, então, seguia o padrão de organizações locais, que desempenhavam, ao mesmo tempo, tanto funções de incorporação quanto de construção. Recobrando relatórios do ano 2001, do Sinduscon-CE, constata-se que, das 175 empresas atuantes no mercado imobiliário, aproximadamente $65 \%$ registravam apenas um empreendimento na fase de construção. Esse dado releva o porte dessas empresas e a sua capacidade de atuação e endividamento, concentrando-se em finalizar um empreendimento para, assim, prosseguir sua atividade.

Rufino (2012), sobre esse mesmo relatório, acrescenta que grande parte desses empreendimentos era realizada por pessoas físicas e que, apesar da aparente pulverização do setor, uma vez que havia 175 empresas atuantes realizando empreendimentos em 2011, apenas uma pequena parcela de $12 \%$ detinha metade das ofertas do mercado. Isso traz um novo entendimento à estrutura tradicionalmente compreendida do mercado imobiliário de Fortaleza. Apesar de a produção pulverizada, há uma concentração de empreendimentos em poucas empresas.

Em Fortaleza, constituem-se empresas de vários portes e é importante ressaltar que, na indústria da construção desta Cidade, tradicionalmente, predomina, por muito tempo, uma estrutura mais vertical em que a direção e o desenvolvimento das 
atividades são associados à figura de engenheiros e cargos técnicos diretamente relacionados ao processo construtivo.

Por esse mesmo motivo, muitas das grandes empresas tradicionais no mercado imobiliário só alcançavam seu crescimento e expansão ao se vincularem à ação direta ou indireta das elites econômicas locais. As empresas que alcançaram maior porte estiveram ligadas a grandes empresários que investiam capitais em empreendimentos de alto padrão, utilizando-se do segmento imobiliário como destino final para excedentes e lucros do comércio e da indústria.

São exemplos dessas parcerias entre pequenas construtoras de engenheiros, associadas ao capital de oligarquias, que deram origem a empresas de grande atuação local, a Diagonal, Mota Machado, Colméia e Porto Freire. Em alguns casos, o próprio grupo empresarial monta sua construtora, como é o caso da Idibra, fundada em 1968, pertencente ao grupo M. Dias Branco.

Outro exemplo é a construtora Mota Machado, que passou a ter participação tão ativa do capital associado aos donos do Sistema Jangadeiro de Comunicação, que se tornou indissociável ao grupo. Essa realidade pode ser explicada pela peculiar concentração de terrenos que esses grupos detêm, encontrando na construção civil uma razão de aplicar e reproduzir seus capitais e estender seus negócios relacionados à propriedade da terra.

O entrelaçamento da atividade imobiliária com as elites econômicas, em Fortaleza, parecer ser um importante recurso de alavancar capitais e de reproduzi-los por meio da atividade imobiliária. Segundo Rufino (2012), quando a parceria entre a elite econômica não acontece diretamente, resultando na própria reorganização da estrutura da empresa, acontece indiretamente como agente financiador dos empreendimentos. A autora ressalta, ainda, que a constituição desses arranjos poderia ser dada na base da permuta e firmada na compra ou cessão, por parte dos grandes empresários, que garantiriam a troca em unidades de empreendimentos.

A persistência do movimento de capitais dos setores produtivos para a propriedade da terra, como consequência da continuada reprodução do capital no setor de origem, é um traço característico das cidades brasileiras. Em Fortaleza, podese notar uma forte coesão entre os grandes grupos econômicos, a propriedade fundiária e o financiamento ao setor imobiliário. 
Essa discussão respalda-se em muitos autores que estudam a produção do espaço, a exemplo de Gottdiener (1997), ao postular a ideia de que "os investimentos imobiliários constituem um setor de formação de capital e realização da mais-valia, especialmente, quando o circuito primário (industrial) perde essa capacidade". (P.185). Aqui é importante frisar, mais uma vez o fato de que o componente produtivo e industrial faz parte da atividade imobiliária, contudo, seus lucros e a ampliação do capital têm origens diversas, fazendo parte dessa composição a reprodução do capital no espaço e nos seus processos de valorização da terra.

Paralelo ao capital advindo das elites econômicas, outra grande fonte de investimento no setor imobiliário em Fortaleza vem da sua articulação com o turismo. Em 2005, segundo dados do Sinduscon-CE, o valor que o capital estrangeiro representava no mercado variava de $8 \%$ a $10 \%$. Adjunta às regiões litorâneas, essa atuação atingia um percentual de 30\%, reforçando sua atividade em localizações privilegiadas e de atrativos para esse capital.

Dos anos de 2002 a 2007, os investimentos estrangeiros no setor imobiliário no Estado do Ceará foram estimados em 423,3 milhões de reais, sendo praticamente o dobro dos valores investidos no turismo, que chegaram a 217,9 milhões de reais durante os mesmos anos (CBP-Ce, 2008). Esses dados sinalizam investimentos anteriores à crise internacional em 2008, que, se por um lado, representava uma queda nos compradores estrangeiros, coincide, também, com o momento de grande expansão das indústrias nacionais intensamente capitalizadas. Respaldadas em uma política de oferta de crédito e incentivo à construção, asseguram a contínua valorização da atividade do setor imobiliário.

Junto à caracterização dos agentes que participam da atividade imobiliária em Fortaleza, destacam-se os corretores. Hoje, a Capital conta mais de 10 mil profissionais especializados em comercialização e vendas de imóveis. Segundo dados do Creci-CE, o mercado possui cerca de 400 imobiliárias atuantes em diversos municípios da região, e que estão ainda em decurso de ampliação. Das 17 mil escrituras registradas, em 2006, equivalente a mais de 1000 registros por mês, apenas 800 foram de iniciativa direta sem intermédio de corretores.

Rufino (2012), em sua pesquisa sobre o fortalecimento da incorporação em Fortaleza, destaca na organização dos agentes responsáveis pelas vendas de imóveis 
no mercado dessa Cidade, o predomínio de efetivação por corretores autônomos. Apesar da crescente centralização de imobiliárias, o mercado ainda exprime, como particularidade, a dispersão da atividade de vendas nas figuras autônomas e fortemente personificadas em cada corretor.

Tal se expressa como uma dificuldade para os investidores de fora, visto que a rede de relacionamentos e esforços envolvidos para concretizar os ganhos nos atos da venda depende de laços e da importância desse grupo de corretores autônomos. Uma vez que o mercado não se polariza em empresas que concentram essas vendas, manejar esse conhecimento requer uma presença local e certo grau de conhecimento dessa rede de contatos.

É importante destacar dinâmicas e movimentos próprios do mercado imobiliário em Fortaleza. Por agregar um grande número de pequenas empresas e em decorrência da dificuldade de enfrentamento de dificuldades em comum, grupos de empresas buscaram iniciativas que tragam inovação, melhorias de financiamento e desenvolvimento de outras tecnologias.

Entre essas iniciativas, cita-se a Inovacon, uma articulação entre empresas e universidade, que buscam, desde 1998, soluções e inovações para o setor. Ainda dessa articulação, destaca-se o desenvolvimento do PBHQ-H - Programa Brasileiro de Qualidade de Produtividade. Esse adquire ainda maior importância, uma vez que, para ter acesso ao financiamento da CEF, é necessário comprovar a capacidade administrativa, financeira e técnica da empresa, e um dos requisitos usados como qualificação do sistema da gestão da obra, se não o único, é o PBQP-H.

Outra iniciativa das empresas construtoras cooperadas é a Coopercon, que se insere no setor imobiliário, permitindo aos seus associados se organizarem para requisitar compras de insumos para construção. Ganha importância, pois se torna uma solução ante o relativo isolamento de Fortaleza e a dificuldade de obtenção local de vários insumos e tecnologias. Essa organização garante ao setor reduções de custo para aquisição de materiais por via dessa cooperativa de compras, que aufere em volume os pedidos a serem negociados.

Enfatiza-se, por fim, o fato de que a instituição que alcança a maior representatividade junto aos núcleos de empresas da indústria da construção civil, o Sinduscon-CE, fundado em 1942, representa os interesses do setor em todo o Estado 
do Ceará, junto ao Governo e perante a sociedade, e se consolida como a imagem do setor de empresas construtoras e incorporadoras.

Atualmente, o Sinduscon-CE conta com a representatividade de cerca de 600 empresas. Durante esta investigação, por várias vezes, foi possível observar os interesses do setor sob a voz dessa organização, negociando, pressionando e apontando direções que, na visão das empresas, são salutares ao PMCMV.

Todas as articulações mencionadas demonstram organização entre as pequenas e as grandes empresas que optam por adotar estratégias para compensar as restrições de financiamentos durante um longo período e a falta de acesso ao crédito imobiliário na região. A unidade e a dinâmica concederam ao mercado um teor e uma intensa coesão, pressionam por garantias diante de suas desconfianças em relação aos investidores de fora.

É importante salientar que a maior representatividade do grupo de interesse do setor imobiliário se articula em torno da organização das empresas da construção civil. Este é um traço identificado em Fortaleza, pois, na Cidade, a maior representatividade e a maior força concedidas ao setor imobiliário gravitam ao redor das grandes empresas que cresceram advindas do setor da construção civil.

As características locais do mercado imobiliário foram intensivamente influenciadas por estruturas e intervenções no plano federal. O setor imobiliário se reorganiza com a entrada de outras condições de financiamento. Após um quadro de década de retração do financiamento imobiliário pelos bancos, característico dos anos de 1990, em que a expansão imobiliária de Fortaleza se manteve e se estruturou na mobilização de capitais locais, existe uma guinada em direção aos massivos investimentos na construção civil. Houve, também, drásticas repercussões na expansão desse setor desde a primeira década do século XXI.

Procura-se, agora, especificar as empresas envolvidas na atividade imobiliária e como estas se organizam ante as expressivas mudanças evidenciadas no aumento do financiamento e reorientação de mercados.

Inicialmente, é importante destacar, cada empresa tem especificidades, trabalhando com um determinado ou produtos diferentes, possui arranjos distintos, tem posicionamento de mercado, tamanho, estrutura e atuação diversa, contudo, é possível traçar algumas dinâmicas próprias do caso de Fortaleza. 
Para isso, será usada uma estrutura que apontará, de modo geral, a organização das empresas atuantes no mercado imobiliário local. Reúnem-se como agentes do setor imobiliário junto ao PMCMV as grandes empresas nacionais em busca de expansão de seus mercados, as construtoras e incorporadoras locais de maior porte e, por fim, as empresas menores, associadas ao Sinduscon-CE.

\subsubsection{Grandes Empresas Nacionais de Capital Aberto}

A ampliação dos investimentos do mercado das habitações no Território Nacional trouxe um momento muito particular para as construtoras e incorporadoras, deu condições para a concentração e centralização do capital no setor imobiliário e da construção civil. A concentração foi marcada pela expansão dos negócios, ampliação dos mercados, intensificação da produção e ampliação do número de equipamentos e trabalhadores no Brasil e, com isso, o crescimento de muitas empresas do setor.

A centralização do capital evidencia-se por meio da associação entre empresas, a absorção de uma pela outra, ou por meio de fusões. Além dessas estratégias de reestruturações e absorções, acontece paralelamente a articulação de parcerias e subcontratações simultâneas com diversas outras empresas autônomas. Outra estratégia que transforma o setor é a abertura de capitais na bolsa de valores, que amplia possibilidades das captações de recursos no sistema financeiro. Todas essas estratégias são elementos da chamada reestruturação imobiliária.

Se o entrelaçamento do setor imobiliário com o financeiro, em si, não se constitui como algo propriamente novo, uma vez que, como visto, a atividade imobiliária requer grandes capitais por parte dos produtores e de recursos para garantir sua demanda e consumo, a abertura de capitais nas ações da bolsa do setor financeiro é, sim, uma novidade. Pode-se dizer que, no caso brasileiro, essa realidade começa nos anos de 2005, sendo algo recente na organização do setor imobiliário nacional.

Algumas empresas passaram pelo processo atual de abertura de capitais, inserindo-se em um procedimento de grandes mudanças em sua organização como setor imobiliário, porquanto, associadas a um grande volume de capital, essas empresas passam a redefinir suas estratégias de produção imobiliária. No ato da 
abertura do capital, elas se inserem em um conjunto novo de regras que exige todo um esforço de precificação e valorização, além de requisições de transparências, relatórios das informações financeiras e estratégias futuras.

Essas empresas, redefinidas com grandes recursos de capital e diante do imperativo da própria lógica financeira de projeções crescentes, agora determinam estratégias para ampliar seu aumento de liquidez e isso leva ao fortalecimento do banco de terrenos das grandes empresas capitalizadas.

Rufino (2012) e Bonduki (2008) reportam-se a uma corrida para a formação dessas reservas de terreno, a garantia da propriedade de terra se torna central para projetar a valorização de uma empresa imobiliária, uma vez que a sua expectativa de ganhos futuros está associada a essa condição por demais fixa, a terra urbana. 0 controle desse recurso garante, também, a seguridade do negócio, visto que, em momentos de aumento de preço do terreno e de extrema valorização fundiária, significaria riscos aos empreendimentos imobiliários.

Esse movimento de expansão de produção e de necessidade de projeção de resultados sempre crescentes em suas ações se reflete em uma busca por novos mercados, o que pode ser entendido tanto em termos de diversificação de produtos atendendo a outros segmentos que não só o mercado de alta renda quanto em termos de expansão territorial.

Essas grandes empresas racionalizam sua produção e buscam estratégias produtivas para a população com menor rendimento, uma vez que o Governo garante essa possibilidade com o estímulo de oferta de crédito e o resgate das políticas habitacionais.

A chegada dessas grandes empresas ao "mercado popular" ou "segmento econômico", ou seja, a produção de casas para rendas que seriam equivalentes às faixas 2 e 3, à medida que o Programa se desenvolve, enseja confiança na capacidade de pagamento das populações de rendimento ainda menores. Com base nas próprias mudanças e incentivos do PMCMV à produção para a faixa 1, as empresas de capital aberto, também, passam a diversificar seu produto para o que antes era compreendido como habitação social, produtos voltados à renda de 0 a 3 saláriosmínimos. 
A própria natureza dos empreendimentos direcionados aos segmentos econômicos demandava produção em grande volume, que, garantida por um grande programa habitacional e associada a um movimento de "expansão geográfica", como denomina Rufino (2012), asseguravam as bases do grande crescimento em volume de produção. A pesquisa de Shimbo (2010) reforça essa ideia, quando exprime que, em 2007, "empresas de capital aberto dispunham de terrenos espalhados por todo o Brasil em um total correspondente a cerca de 37 bilhões de reais, o que seria suficiente para realizar mais de 400 mil unidades habitacionais". (P.150).

Há um grande fluxo migratório de empresas vindas do centro-sul em busca de novos contratos, demanda solvável e terrenos mais baratos. O Nordeste configura aposta privilegiada pela menor dinâmica de seus mercados e garantia de menor preço da terra urbana. As empresas também viam vantagem nas diferenças entre os custos da construção civil em relação à região Sul, que possui o valor médio do Custo Unitário Básico (CUB) $)^{35}$ mais elevado do País, tem uma queda de $12 \%$ para a região Nordeste.

Rufino (2012) exprime que há uma aposta no desenvolvimento desses mercados em que, historicamente, estiveram restritos a grandes desigualdades sociais e à pequena demanda solvente e repercutiram em formas menos avançadas na produção do espaço e com grande precariedade no habitacional. Com um mercado imobiliário em que as grandes empresas do setor local se focavam no mercado de alto padrão, as grandes empresas nacionais que já se aproximavam de um mercado popular no Sul e Sudeste apostam no seu diferencial e tecnologia desenvolvida para ampliar mercados em direção a outras regiões.

Pode-se dizer que o movimento de expansão das empresas quando vinculado ao PMCMV demonstra duas fases distintas. No primeiro momento, as empresas nacionais de capital aberto parecem investir na RMF, principalmente, na produção para o segmento considerado de mercado, o segmento econômico, onde estabelecem parcerias e são as grandes responsáveis da produção nas faixas 2 e 3. Já na segunda fase do Programa, em virtude dos incentivos à produção junto ao FAR na faixa 1, com a ampliação de metas e, sobretudo, com a possibilidade de aumentar o número dos

\footnotetext{
${ }^{35}$ Determina o custo global da obra para fins de cumprimento do estabelecido na lei de incorporação de edificações habitacionais em condomínio. É baseado em dados de salários e preços de materiais e mão de obra, além de despesas administrativas e equipamentos previstos.
} 
empreendimentos para até 5000 unidades, as grandes empresas nacionais, oriundas de outros estados, passam, também, a concorrer na produção destinada à faixa 1.

Como foi visto no Capítulo 1, o Programa se reestrutura em sua segunda etapa e, nesse sentido, avança com vistas a ampliar a inserção das faixas de rendas mais baixas dentro da ideia de habitação de mercado. As pressões políticas do setor imobiliário em relação ao Estado para alcançar a viabilidade da habitação para as classes que compunham a grande maioria do défice, cerca de $89,6 \%$ das famílias, garantiriam um negócio com um "mercado consumidor" sem fim, da ordem de quatro milhões de famílias ${ }^{36}$.

A atuação de grandes incorporadoras e empreiteiras para a Faixa 1 foi bastante significativa na região Sudeste, sendo pouco representativa no Norte e Nordeste. Nessas regiões, foi destacada a participação de empresas locais e regionais que, em muitos casos, adquiriram experiência na produção de habitação de interesse social pela prévia atuação no Programa de Arrendamento Residencial (PAR). Na segunda fase do Programa, verifica-se a redução da atuação das grandes empresas no Sudeste e sua ampliação no Norte e Nordeste. A atuação das grandes empresas no Norte e Nordeste, desde 2011, corresponderá também a uma tendência de ampliação do porte dos empreendimentos. Essas questões serão vistas e aprofundadas mais adiante, no Capítulo 3 deste trabalho.

\subsubsection{Grandes Empresas Incorporadoras Locais e Grandes Empresas}

\section{Construtoras Locais}

O setor imobiliário de Fortaleza, tradicionalmente, foi ocupado por grandes empresas do setor da construção. Advindas de organizações menores que se capitalizaram com o excedente de capitais das oligarquias regionais e por meio dos investimentos externos na área de turismo e hotelaria, algumas dessas atingiram portes maiores. Relativamente capitalizadas, elas passam, muitas vezes, a diversificar o mercado onde atuam, estendendo sua atuação para um âmbito regional, mas concentrando forte foco em seu núcleo original, Fortaleza.

\footnotetext{
${ }^{36}$ Informação da Fundação João Pinheiro.
} 
O porte dessas empresas é exemplificado por "rankings" do próprio mercado imobiliário, e, serão, aqui, mostrados na tabela logo abaixo. No topo do "ranking" nacional aparecem as grandes empresas de capital aberto, que, de longe, acenam para um volume de produção e de investimentos que não podem ser equiparados à realidade local. São empresas que produzem nacionalmente, mas, o que interessa a esta pesquisa é discutir a presença delas na construção em Fortaleza como entidades reconhecidas na escalação das maiores empresas da construção civil do País. Destacase o fato de que esse reconhecimento leva em consideração o número de obras produzidas e o valor de metros quadrados construídos, sendo, realmente, uma premiação com foco no poder de construção.

Identificam-se, dentre as empresas premiadas, Mota Machado, Colméia, Porto Freire, Cameron, Terra Brasilis, Diagonal, Marquise e Idibra. Todas são representantes locais que conseguem ter representatividade nacional junto ao grupo de grandes construtoras brasileiras - os quatro primeiros nomes constam no "ranking" da ITCnet durante os anos de 2005 a 2010. 
Tabela 02: Ranking das 100 maiores empresas construtoras do Brasil de 2010.

\begin{tabular}{|l|l|r|r|}
\hline 1 & Gafisa/Fit/Tenda & $5.859 .271,71$ & 430 \\
\hline 2 & Cyrella/Goldztein & $3.315 .466,71$ & 73 \\
\hline 3 & Even & $2.483 .888,97$ & 70 \\
\hline 4 & Brooksfield & $2.461 .608,14$ & 50 \\
\hline 5 & MRV & $2.384 .488,23$ & 0 \\
\hline 6 & Grupo Capuche & $1.453 .151,16$ & 23 \\
\hline 7 & Wtorre & $1.195 .018,00$ & 16 \\
\hline 8 & GoldFarb & $1.171 .830,03$ & 61 \\
\hline 9 & Toledo Ferrari & $1.106 .658,96$ & 19 \\
\hline 10 & Direcional & $1.090 .219,36$ & 35 \\
\hline 11 & Sinco & $1.009 .268,00$ & 23 \\
\hline 12 & Grupo Acre (Klabin/Sebin) & $1.006 .891,00$ & 22 \\
\hline 13 & Pereira Alvim & $986.709,23$ & 11 \\
\hline 14 & Racional & $952.168,00$ & 19 \\
\hline 15 & Rodobens & $869.611,00$ & 83 \\
\hline 16 & Hochtief & $854.200,00$ & 12 \\
\hline 17 & Trisul & $765.936,16$ & 22 \\
\hline 18 & Shahin & $735.393,51$ & 23 \\
\hline 19 & Moura dubeux & $730.089,68$ & 46 \\
\hline 20 & Borges Landeiro & $703.509,98$ & 9 \\
\hline 21 & Thá & $652.840,58$ & 35 \\
\hline 22 & Sertenge & $646.111,64$ & 23 \\
\hline 23 & Narcon & $607.919,44$ & 27 \\
\hline 24 & Método & $604.758,77$ & 12 \\
\hline 25 & Serpal & $603.195,00$ & 31 \\
\hline 26 & Galwan & $589.800,27$ & 24 \\
\hline 27 & MAC & $569.502,00$ & 13 \\
\hline 28 & EzTec & $546.198,72$ & 17 \\
\hline 29 & Bueno Netto & $534.201,30$ & 15 \\
\hline 30 & Plano e Plano & $480.241,24$ & 17 \\
\hline & & & \\
\hline
\end{tabular}

\begin{tabular}{|l|l|r|r|}
\hline 31 & Lúcio Engenharia & $479.655,65$ & 6 \\
\hline 32 & BKO & $457.005,56$ & 10 \\
\hline 33 & Metron & $433.245,30$ & 25 \\
\hline 34 & Santa Bárbara & $422.000,00$ & 17 \\
\hline 35 & Dominus & $399.011,76$ & 14 \\
\hline 36 & Criciúma & $398.872,35$ & 46 \\
\hline 37 & R. Yazbek & $396.188,00$ & 18 \\
\hline 38 & Sá Cavalcante & $387.038,33$ & 11 \\
\hline 39 & EBM & $378.052,39$ & 16 \\
\hline 40 & Plaenge & $362.323,00$ & 18 \\
\hline 41 & Grupo Lider & $336.267,91$ & 11 \\
\hline 42 & DMO & $330.014,40$ & 10 \\
\hline 43 & MPD & $281.189,63$ & 14 \\
\hline 44 & Arbore & $254.015,67$ & 20 \\
\hline 45 & Mota Machado & $235.806,58$ & 15 \\
\hline 46 & Pernambuco & $232.133,51$ & 17 \\
\hline 47 & Dan Hebert & $229.470,95$ & 12 \\
\hline 48 & Rio Verde & $223.452,00$ & 16 \\
\hline 49 & JL & $218.251,99$ & 12 \\
\hline 50 & M. Bigucci & $211.314,41$ & 15 \\
\hline 51 & Dialogo & $207.581,00$ & 11 \\
\hline 52 & Tarjab & $205.009,00$ & 18 \\
\hline 53 & Lorenge & $195.208,29$ & 13 \\
\hline 54 & CV Lopes & $190.121,00$ & 19 \\
\hline 55 & Cameron & $182.882,62$ & 15 \\
\hline 56 & MZM & $180.882,62$ & 11 \\
\hline 57 & Fontana & $179.305,78$ & 22 \\
\hline 58 & Habitare & $146.343,56$ & 17 \\
\hline 59 & Morar & $146.112,86$ & 5 \\
\hline 60 & Fortenge & $145.015,49$ & 5 \\
\hline & & & \\
\hline
\end{tabular}

Fonte: ITCnet, Ranking das 100 maiores construtoras de 2010. ${ }^{37}$

Rufino (2012) ressalta que, apesar dessas empresas não serem incorporadoras puras nem terem uma estrutura que se assemelha às empresas do Sul e Sudeste, se organizam e estabelecem parcerias com esforços evidentes no sentido de ampliar sua competitividade e se reestruturar em um mercado que cada vez mais aponta empresas que modernizam e financeirizam seus processos e sua gestão.

A força das grandes construtoras locais no mercado imobiliário é realmente significativa. Os grandes lançamentos e os maiores investimentos imobiliários são expressos nos principais jornais. Destaca-se o fato de que essas empresas participam

${ }^{37}$ Mostra-se as primeiras 60 maiores empresas elencadas pelo ranking de 2010. Destaque para as 10 maiores empresas que coincidirão com as que vão ter maior desempenho do MCMV em território nacional. Destaque também, para as empresas Cameron e Mota Machado, empresas locais com alcance e porte de influência regional. 
tradicionalmente do mercado de alta renda, focando em produtos para uma pequena parcela da população.

Pode ser estranho pensar que os grandes empreendimentos imobiliários de alta renda sejam gestados por empresas que começaram como pequenas construtoras, mas, há em Fortaleza um entrelaçamento ou superposição das atividades. As construtoras são também incorporadoras dos imóveis. $O$ surgimento de incorporadoras puras que vão gerir substancialmente os investimentos na obra é algo novo para a realidade local.

O aparecimento das empresas construtoras incorporadoras puras é a principal questão da tese de Rufino (2012), que destaca ter origem diversa e seus organizadores não mais possuem vínculo direto com a indústria da construção, além do "perfil empresarial" parecer se assemelhar com tendências de uma gestão de grandes grupos nacionais, mais focados em negócios imobiliários em que a construção passa por uma nova lógica financeira.

Muitas dessas empresas não optam por diversificar sua cesta de produtos, permanecendo a atuar com o mercado de alta renda. Mesmo em momentos de grande oferta de crédito, e junto à recuperação de fundos para a produção habitacional, esse investimento não parece ser atraente. Com o lançamento do PMCMV, contudo, e a chegada das empresas de outras capitais brasileira, algumas grandes construtoras locais reorientaram sua atuação.

\subsubsection{Pequenas Empresas Locais}

A maioria das empresas atuantes no setor imobiliário e de construção em Fortaleza se situa aqui, realizando um menor número de empreendimentos e atuando diante das oportunidades do mercado. Conforme descrito anteriormente, essas têm como característica o fato de trabalharem com a superposição de construção e incorporação; atuavam com capital próprio e, por isso, realizavam poucos empreendimentos por vez.

Em um mercado com restrições de financiamentos e falta de acesso a crédito imobiliário, pode se explicar o interesse dessas pequenas e médias empresas em 
participar das ofertas públicas para a produção de habitação e, mais recentemente, da produção habitacional associada ao programa federal.

Desde os anos 1990, é interessante notar que os recursos advindos da União também já se articulavam com o financiamento da produção, como mencionado no capítulo anterior. Há um movimento de crescente organização de recursos para ampliar a oferta do mercado imobiliário até a baixa renda. Em Fortaleza, os empreendimentos financiados pela CEF, durante os anos 2000, sem incluir o PMCMV, foram, principalmente, encabeçados pelo PAR. Recebendo aportes do FGTS e, posteriormente, do Plano de Aceleração do Crescimento (PAC), o PAR paulatinamente foi adotado pelas empresas interessadas na produção da moradia popular.

O modelo de arrendamento residencial prescindia da figura do intermediador de venda e a etapa de comercialização simplesmente não existia. Por este motivo, imobiliárias e incorporadoras puras não tinham interesse em participar do Programa. É interessante notar que, junto ao programa PAR, muitas empresas continuaram no ramo do mercado de habitações populares, ampliando seus negócios e se aliando para pressionar por melhorias para que as empresas passassem a atuar nesse setor.

Pequeno e Vieira (2016) destaca a continuidade das empresas atuantes junto ao PAR na RMF. Ao longo dos anos 2000, o Programa foi amplamente utilizado por construtoras locais, realizando empreendimentos de acanhado porte, inseridos em bairros periféricos e populares sob a forma de condomínio fechado.

Com um tamanho muito próximo do que seria produzido na primeira etapa do PMCMV, visto que havia restrição de unidades por empreendimento e os condomínios se limitavam até 250 unidades, essas empresas atuaram, de certa forma, principalmente, na faixa 1 , atendendo as demandas de habitação de interesse social e trazendo novos desafios, dinâmicas e regras para o atendimento desse novo tipo de usuário.

Após explanar sobre os agentes relacionados ao grupo do setor empresarial responsável pela incorporação, construção e comercialização das unidades, passa-se, agora, a examinar aqueles diretamente associados ao Estado, os agentes que assumem as tarefas de planejamento, aprovação e gestão do PMCMV. 


\subsubsection{Os agentes financeiros e o setor público}

Os agentes ligados ao Estado existem sobrepostos às diversas esferas de atuação. Da parte do Ministério das Cidades, verifica-se sua ocorrência somente quando os processos decisórios perpassam as deliberações locais. Sua atuação específica se associa a grandes projetos onde há amplo volume de decisões e recursos envolvidos.

Como principal agente operador do PMCMV, destaca-se a Caixa Econômica Federal, que está em todos os municípios da RMF por meio da Gerência de Desenvolvimento Urbano - GIDUR. Por ocasião das entrevistas exploratórias desta pesquisa se constatou que a GIDUR havia acabado de passar por uma reestruturação de sua gestão, subdividindo-se em GIHAB (Gerência Executiva de Habitação) e GIGOV (Gerência Executiva de Governo), sendo que a primeira se concentra em projetos ligados ao setor empresarial enquanto a segunda se vincula estritamente aos projetos que absorvem demandas governamentais, notadamente, os grandes projetos que absorvem a faixa 1.

Mesmo ante a disponibilidade de crédito em um contexto de provisão favorável à produção privada de moradias populares, o Estado do Ceará denota baixa adesão ao PMCMV. A RMF, apesar de ter um percentual mais alto do que a realidade das demais regiões de todo o Estado, ficou muito aquém de suas expectativas. Essa realidade foi anunciada em diversos jornais locais.

No balanço de um ano de lançamento do programa, divulgado pelo Ministério das Cidades e a Caixa Econômica Federal, em abril, o Ceará ocupava o penúltimo lugar na lista que avaliou o total de unidades entregues em cada estado, tendo atingido somente $6 \%$ da meta ${ }^{38}$.

As razões apontadas no discurso recorrente do mercado imobiliário para explicar a dificuldade de implementação do PMCMV no Ceará são diversas. As principais são: a falta de terra urbanizada com baixos $\operatorname{preços}^{39}$ e a dificuldade de

\footnotetext{
${ }^{38}$ Matéria publicada no $O$ Estado, em 28 de julho de 2010.

${ }^{39}$ De acordo com o presidente do Sinduscon, Roberto Sérgio, um dos obstáculos que ainda perdura é o encarecimento dos terrenos onde as obras serão edificadas, além da falta de rede de esgoto em alguns casos. Publicação no O Estado, 28 de julho de 2010.
} 
aprovação junto à $\mathrm{CEF}^{40}$. Em relação a esta última dificuldade, a CEF passou por diversos treinamentos em outras unidades de vários estados, do que decorreu reorganização de sua estrutura. Mesmo assim, as dificuldades persistiram. Técnicos da CEF em reuniões realizadas no transcorrer desta pesquisa sinalizaram como possíveis causas desse descompasso na contratação de empreendimentos para o PMCMV, principalmente, para a faixa 1: precariedade urbanística em setores sem infraestrutura e sem serviços; baixas condições de desenvolvimento institucional nos municípios; e contínua valorização dos terrenos e especulação imobiliária.

Ao cruzar as informações quanto às dificuldades encontradas para implementação do PMCMV, verificou o problema da aquisição de terrenos, seja ele pelo valor, dado que importa ao investidor do setor empresarial, seja pelas condições de infraestrutura, dado que importa ao órgão avaliador (CEF), essa parece ser, então, o nó da questão.

Após alguns anos de lançamento do PMCMV, o Banco do Brasil ganhou, também, espaço como instituição financeira atuante no Estado do Ceará, com contratos de grandes empreendimentos. Com capacidade de aprovação e financiamento de projetos, O BB passa a ser outra instituição influente junto às prefeituras e governos. Na segunda etapa do Programa, participa de grandes contratações, a exemplo do Conjunto Cidade Jardim II e da Alameda das Palmeiras, totalizando em 10.960 unidades somente nesses dois empreendimentos.

Em 2013, o Governo regulou o fato de que é apenas por via da Caixa Econômica Federal e Banco do Brasil que se podem operar contratações em cidades com mais de 50 mil habitantes. Em virtude dessa regulação, os pequenos bancos privados que participavam das ofertas públicas em cidades de menor porte ficam impossibilitados de contratar mais unidades na RMF.

Após contextualizar a formação da RMF, campo empírico deste estudo, refletir sobre os agentes envolvidos junto ao PMCMV e as tendências de desenvolvimento e expansão nesta região, desvendando a concentração urbana e suas dinâmicas

40 "Em reunião, ontem (22), com empresários do setor da construção do Ceará, o vice-presidente da Caixa Econômica Federal, Jorge Hereda, disse que não há motivo para o Ceará ocupar o penúltimo lugar no ranking nacional na implantação do Programa Minha Casa, Minha Vida. Projetos para construção de 2.600 unidades do programa no estado aguardam aprovação na Caixa. A previsão é de que os projetos sejam aprovados num prazo de 15 dias. Em reunião na CBIC em 23 de abril de 2010".<<http://www.cbic.org.br/sala-de-imprensa/noticia/minhacasa-minha-vida-ganhara-agilidade-no-ceara $>>$ acessado em maio de 2014. 
socioespaciais, passa-se, agora, no capítulo a seguir, a explorar alguns dos resultados alcançados com a aplicação desta pesquisa. São análises decorridas do processo desta investigação, em que se pontuam os agrupamentos e a organização do setor imobiliário ao longo deste Programa, a localização de seus empreendimentos e os territórios em que focaram sua produção.

Capítulo 03 - A produção do Programa Minha Casa, Minha Vida na RMF: Fortaleza, Maracanaú e Caucaia.

De acordo com o enfoque delimitado por este estudo pretende-se mostrar neste capítulo alguns dos resultados do PMCMV percebidos na RMF no decorrer da análise desta investigação. Os principais temas analisados com amparo nas observações, entrevistas e dados coletados durante esta pesquisa são os processos de decisão dos arranjos institucionais, a atuação do setor imobiliário e os traços característicos da produção do PMCMV na RMF, pontuando os agrupamentos e a organização do setor imobiliário ao longo do Programa, a localização dos empreendimentos e os territórios que se tornaram foco dessa produção.

Nesse sentido, busca-se problematizar e entender os movimentos gerados como estratégias de valorização do espaço, uma vez que a produção imobiliária tem como característica avançar em frentes de apropriação territorial como racionalidade de reprodução do capital, ainda que associada a um programa habitacional de interesse social.

A escolha dessa análise privilegia a escala regional da RMF e seus municípios, em que três são problematizados, uma vez que discute a ativação dos terrenos que antes não eram nichos de atuação do mercado tradicional. A produção nesses municípios é dado importante para este estudo. Fez-se necessário, entretanto, se proceder a um recorte espacial. Com base nos dados coletados, pode-se alicerçar a definição que tomou como referência a contratação de conjuntos habitacionais do início do PMCMV até março de 2015.

Observou-se que, dos 204 empreendimentos contratados no período de 2009 a 2015, 162 se concentraram justamente no contínuo urbano de Fortaleza, Maracanaú e 
Caucaia. Além de centralizarem cerca de $80 \%$ das contratações dos empreendimentos, esses três municípios possuem grande concentração demográfica, marcante défice habitacional e predominância de implementos no contínuo urbano caracterizado por essas três cidades. Esses são os principais aspectos que justificam a escolha desse recorte.

A escala definida destaca as condições de implementação do PMCMV na RMF, reconhecendo similaridades e diferenças na maneira e na localização dos empreendimentos, o que possibilita diagnosticar características das escolhas dos terrenos e distinguir os bairros com maior dinamismo do setor imobiliário, assim como realçar a coesão entre a escolha dos terrenos dos novos projetos do PMCMV e a localização de antigos assentamentos informais e conjuntos habitacionais implementados anteriormente.

A escala privilegiada possibilita também observar a relação de proximidade entre os empreendimentos que promoveram os agrupamentos das habitações e identificar os setores com precariedade de acesso à infraestrutura urbana, além de reconhecer a condição de isolamento dos empreendimentos e a centralidade e dinâmica espacial das faixas de renda na base territorial da Metrópole.

Cabe realçar o fato de que foram realizadas visitas de campo junto aos empreendimentos da faixa 1, principalmente, da primeira etapa do PMCMV. Nessas, recorreu-se a entrevistas com síndicos, agentes de saúde e moradores, a fim de melhor compreender o universo pesquisado, que não foca em empreendimentos destacados, mas na dinâmica imobiliária da espacialização desses projetos.

Deste modo, o detalhamento e as situações locais de cada objeto não são pontuados, mas, são, sim, sensíveis a esta pesquisa, que entende a sua abrangência e valida estudos posteriores que aprofundem o debate da inserção urbana de cada unidade habitacional do Programa sob exame.

Outro instrumento fundamental que deu suporte à elaboração deste capítulo foi a análise da base de dados disponibilizados pela Caixa Econômica Federal, em que é possível averiguar de modo geral os resultados quantitativos dessa produção habitacional. Essa base se refere até o mês de abril de 2015. Grande parte dessa base se refere à primeira etapa do PMCMV e foi investigada pelo Laboratório de Habitação da Universidade Federal do Ceará (UFC), em parceria com uma rede de pesquisa 
composta por 11 universidades brasileiras, a partir de projetos de pesquisa aprovados pelo Conselho Nacional de Desenvolvimento Científico e Tecnológico (CNPq) e pelo Ministério das Cidades. Essa rede de pesquisadores investigou o tema da inserção urbana dos empreendimentos contratados pelo Programa.

No decorrer desta pesquisa, percebeu-se que houve uma mudança significativa que diferenciou os dados disponibilizados pela CEF relativos às contratações dos primeiros anos dos empreendimentos acordados após o ano de 2012. Essa mudança diz respeito à chegada de um novo órgão financiador, o Banco do Brasil, que passou a ter grande participação nas contratações das unidades implementadas na RMF.

Desde então, se afirmou a necessidade de considerar e analisar os dados dos contratos cedidos pelo Ministério das Cidades via Banco do Brasil. Cabe destacar, entretanto, o fato de que a tabulação dos mais recentes não provia de alguns dados completos, desta feita, as informações das empresas responsáveis pelos empreendimentos e o volume financeiro das operações foram complementados com pesquisas e contatos junto às construtoras responsáveis. O esforço em atualizar essa base e trabalhar com o desenvolvimento do PMCMV por meio das duas agências operadoras até a data de abril de 2015 define o limite da análise dos resultados do Programa na RMF.

O primeiro elemento a ganhar atenção na análise dos dados pesquisados foi o quadro de barreiras e de impedimentos observados na implementação do PMCMV no Estado do Ceará. Mesmo em meio a um panorama de grande expansão da produção imobiliária e de crescimento econômico evidenciado em conjunto com o desenvolvimento da construção civil em todo o Estado, o Ceará teve, em 2011, a segunda pior colocação dos estados da Federação ${ }^{41}$ relativamente às contratações de empreendimentos do PMCMV, ficando no ano a seguir, 2012, na terceira pior colocação, consolidando sua posição de retaguarda. E, ainda, apesar de a RMF ter concentrado grande parte das unidades contratadas no Estado, houve um baixo rendimento em relação às expectativas do Programa.

À luz da reflexão de Pequeno e Vieira (2015), que pesquisaram essa realidade, se tem como os principais motivos que podem causar essa baixa repercussão junto ao

\footnotetext{
${ }^{41}$ Notícia do Diário do Nordeste em 02.2011: "o balanço disponibilizado pela CEF mostra que o segundo pior desempenho, com apenas $(36,7 \%)$ das contratações previstas, pertencia ao Ceará".
} 
PMCMV as seguintes questões: a) a contínua valorização fundiária na RMF; b) a dificuldade de aquisição de terrenos viáveis para a contratação; c) a falta de infraestrutura urbana nos municípios que repassa aos custos de produção a adequação das soluções de esgotamento e abastecimento de água; d) a fragilidade dos municípios e seus mecanismos de planejamento urbano; e) a análise rigorosa da unidade da Caixa Econômica Federal, que inclusive decorreu em alterações de gerência e reorganização de sua gestão e; f) desinteresse das construtoras de ampliar o mercado até os centros regionais mais distantes, devido à organização de pequena demanda que resultam em diminuta escala de empreendimentos.

Percebeu-se, por meio dos dados analisados, que a inclusão do Banco do Brasil como órgão financiador do PMCMV, após dois anos de ações da CEF junto ao Programa, trouxe à realidade de contratações dos empreendimentos habitacionais ganhos relevantes para a RMF, conforme mostra o gráfico comparativo a seguir.

Gráfico 05: Contratações do PMCMV por agência financiadora na RMF, no PMCMV2.

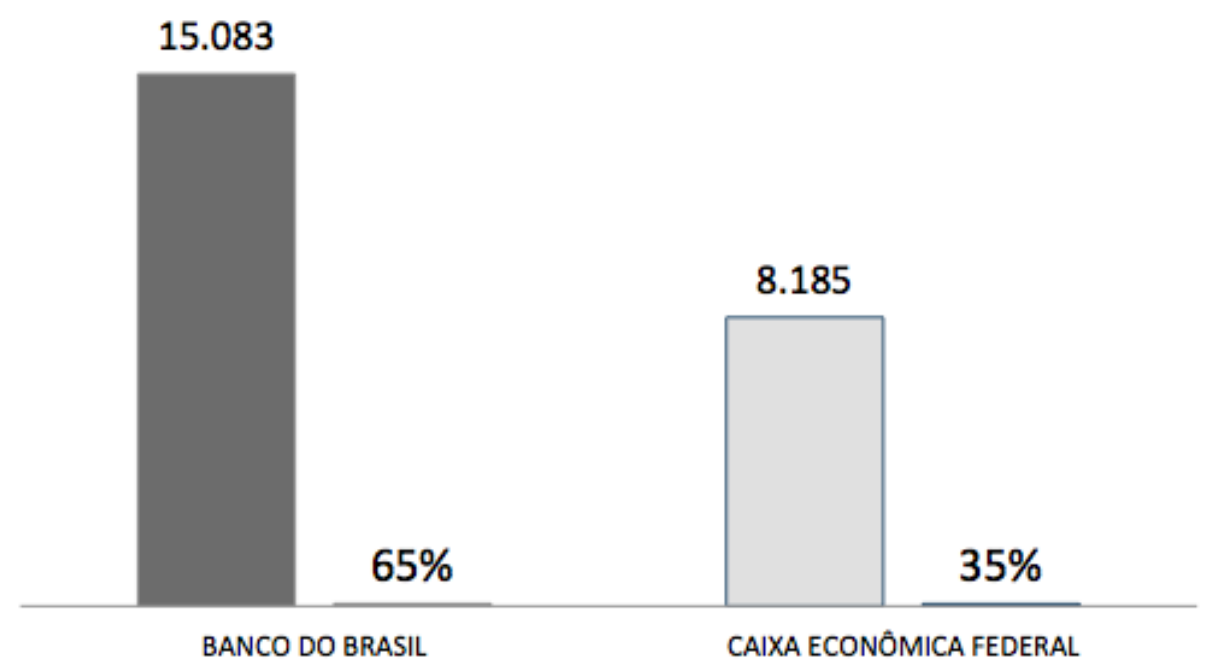

Fonte: Dados Ministério das Cidades - 2015. Elaboração própria.

O gráfico apresentado inclui todos os empreendimentos financiados entre 20011 e 2015, inclusive o Residencial Luiz Gonzaga, que participa das contratações junto ao PMCMV- Entidades por meio da Caixa, com 1796 unidades.

A entrada do novo órgão financiador - Banco do Brasil - foi anunciada pelos jornais locais "como um novo executor que entra no jogo, com a promessa de dar 
maior agilidade ao programa no Estado ${ }^{42 " . ~ N a ~ n o t i ́ c i a, ~ o ~ p r o ́ p r i o ~ s u p e r i n t e n d e n t e ~ d o ~}$ BB divulgou que "a agilidade na aprovação dos projetos será o nosso diferencial". A parceria estabelecida entre o novo órgão financiador e a grande empresa nacional Direcional Engenharia, com apoio do Governo Estadual, foi a aposta para o que os gestores considerassem como melhora no desempenho nas contratações do PMCMV.

O tom das resoluções para a implementação do PMCMV nos patamares estadual e municipal, como será aprofundado, parece apontar que as mudanças sugerem desviar da necessidade de planejamento e melhorias urbanas e se focam em flexibilizações das exigências, ampliação das atratividades, aumento de subsídios, renovação de parcerias, agilidade de processos, retirada de impostos, entre outros. 0 planejamento parece se preocupar apenas com o deslanche e a produção de unidades, tirando do horizonte a discussão sobre a qualidade que essas habitações requerem, quando estão sendo inseridas no tecido urbano.

A explicação do grande crescimento de contratações junto ao Banco do Brasil passa, portanto, pela própria dinâmica que o Governo do Ceará implementou para dar continuidade ao PMCMV, buscando ações ágeis para a retirada do Estado da incômoda terceira pior posição das unidades da Federação no que concerne às contratações junto ao PMCMV. A agência financiadora BB se torna parceira na tarefa de dinamizar o PMCMV e agilitar os processos de contratações.

Faz parte da tentativa em dinamizar essas contratações a ação conjunta que associa Governo Estadual, criação de comitês integrados pelas secretarias das cidades, agências financiadoras e representantes da construção civil - Sinduscon-CE. Em reuniões, esse grupo identificou barreiras e propôs soluções para os problemas detectados que, na maioria das vezes, se conectavam com a ausência de terrenos apropriados para as implementações dos empreendimentos do PMCMV. Visando a superar esta questão, o Governo Estadual aprovou, então, a destinação de recursos complementares para o PMCMV II, os quais ampliaram o valor das unidades no esforço de responder e de fomentar o interesse do setor da construção.

\footnotetext{
42 Notícia do Diário do Nordeste, em 09.2012: "diante de certa lentidão na aprovação dos projetos do PMCMV, comemorava-se um novo agente financiador que, com a parceria com uma grande empresa - a Direcional, seria a grande promessa para deslanchar o programa no Estado. Fonte: http://diariodonordeste.verdesmares.com. $\mathrm{br} /$ cadernos/negocios/acordo-promete-acelerar-obras-do-mcmv-no-ceara-1.609987.
} 
Observa-se em crescente contrapartida por parte dos Governos investimento de volume de recurso para garantir uma infraestrutura mínima às habitações a serem planejadas. Essa iniciativa por um lado é um ganho pela possibilidade de complementar os conjuntos com equipamentos para assegurar a qualidade de vida da população, mas, por outro, esbarra no problema da expansão do mercado de habitação popular para áreas mal infraestruturas e distantes da Cidade, onerando mais uma vez o Estado que arca com o ônus desse tipo de produção.

Ante as ações dos Governos é inevitável destacar os esforços da gestão em orientar recursos do PAC Moradia para soluções associadas às remoções decorrentes das obras da Copa do Mundo de 2014. O Programa Minha Casa Minha Vida em Fortaleza se liga aos processos de remoções de antigas comunidades consolidadas antes das obras de mobilidade urbana. Em meio a um processo de incremento de valorização fundiária, famílias são deslocadas e reassentadas no empreendimento Cidade Jardim, que contrata 5.536 unidades no âmbito do Programa. Esses processos associados ao Estado marcam remoções em que comunidades não foram consultadas, são 22 comunidades realocadas para esse novo empreendimento ${ }^{43}$, registrando uma série de violações ao direito de moradia e "ampliando as periferias" da Metrópole para áreas ainda mais distantes.

Conquanto, essa investigação só concentra estudos nas ações e estratégias ligadas ao mercado imobiliário, há um grande esforço de compreender mais de quatro anos de ação do setor imobiliário junto ao PMCMV, programa que se reestrutura no decorrer de seu processo, como já mencionado. A contínua reestruturação reforça a importância em se dar cronologia à análise, uma vez que as dinâmicas de sua produção denotam significativas variações.

Ao analisar o universo dos empreendimentos aprovados pela CEF, por faixas de renda, percebe-se que, tanto na primeira etapa do PMCMV quanto no desenrolar de sua segunda fase, a maioria das unidades contratadas se concentra junto às famílias de 0 a 3 salários mínimos.

Essa contratação importa a grande demanda, sendo que o massivo de suas construções se encontra na RMF, representando $76,2 \%$ das contratações até o período

\footnotetext{
${ }^{43}$ Ver matéria "Remoções e lutas pelo direito à cidade de Fortaleza" sobre o projeto Veículo Leve sobre Trilhos (VLT) Parangaba- Mucuripe, site do observatório das metrópoles. Consultado em 09/2014.
} 
analisado, ou seja, até abril de 2015. Na faixa de 3 a 6 salários mínimos, esse percentual caiu para $16,9 \%$ das contratações. E, finalmente, nas faixas de maiores rendimentos, de seus seis a dez salários mínimos, os empreendimentos equivalem a $6,9 \%$ do percentual das unidades contratadas.

Esses resultados correspondem à realidade da produção do PMCMV na RMF em sua primeira etapa, quando teve maior produção junto aos empreendimentos voltados às famílias de zero a três salários mínimos, marcando o que caracteriza a produção do PMCMV em Fortaleza.

Essa produção orientada para a faixa 1 merece destaque uma vez que a literatura sobre a produção nacional mostra justamente a dificuldade de produzir habitações onde se concentra o maior défice habitacional, ou seja, na faixa 1. Essa é a que tem a menor solvabilidade e é onde o PMCMV inicialmente encontrava dificuldades para deslanchar sua produção. No contexto federal, só em sua segunda etapa efetivou esse avanço.

Ao fazer um comparativo com a produção nacional, é possível observar que nos primeiros anos de implementação do PMCMV, o mercado popular teve preferência na aplicação dos recursos na faixa 2, correspondendo a $68 \%$ do total dos investimentos; a faixa 1 veio a seguir, com 22\%; e a faixa 3, por fim, com 10\% das aplicações. As faixas 1 e 2 , voltadas para as populações de menor renda, representaram $78 \%$ da aplicação dos recursos do PMCMV, conforme esclarece o gráfico abaixo.

Gráfico 06: Direcionamento dos recursos aplicados por faixa de renda

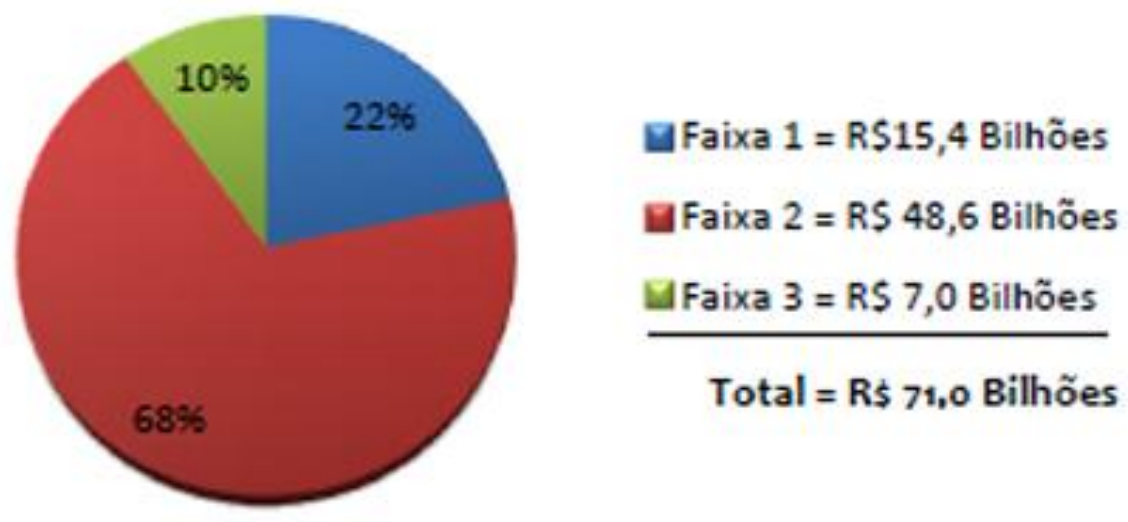

Fonte: Caderno PMCMV ${ }^{44}$

\footnotetext{
${ }^{44}$ Disponível em: www.sedhab.df.gov.br/mapas sicad/conferencias/programa_minha_casa_minha_vida. pdf
} 
Em razão de várias medidas que modificam o quadro administrativo e institucional desde os anos de 1990, assim como de mudanças recentes que propiciam maior segurança jurídica ao setor da construção e ampliam o crédito imobiliário, percebe-se que o aquecimento da construção civil voltou-se aos mercados de alto padrão e o nicho de atuação do mercado imobiliário brasileiro se encaminha para a sua diversificação por vias do mercado popular. A produção se diversifica no Território Nacional, inicialmente para o "segmento econômico", que concentra a produção para as rendas médias na segunda e na terceira faixas de renda.

Recorrendo-se a Cunha (2014), que recupera a evolução da faixa 1 no PMCMV, é possível destacar que, na segunda fase do PMCMV, o FAR se tornou a principal fonte de recursos. Há clara reorientação para o atendimento das classes mais baixas. Explica o citado autor que a produção só recebe contornos maciços em um processo mais tardio, após a disputa por parte das empresas que pressionaram por incentivos governamentais para tornar essa faixa de renda igualmente lucrativa, solicitando a ampliação dos tetos e valores pagos nos financiamentos da produção, viabilizando, assim, o negócio para a primeira faixa de renda.

No caso da RMF, entretanto, em todas as etapas do PMCMV, se observa, em termos proporcionais, que a produção da faixa 1 exprime importante peso na repercussão do PMCMV, que o diferencia dos resultados indicados pela situação nacional. Aqui no Ceará, os empreendimentos direcionados para a faixa 1 representam $81,7 \%$ da produção total. Esse não é um caso isolado, pois, na realidade, a região Nordeste durante a primeira etapa do PMCMV aparece como a maior produtora de unidades habitacionais para as faixas de 0-3 salários mínimos. Essa região passou, portanto, a ser caracterizada tanto por ter grande concentração do défice habitacional quanto por efetuar massiva produção para as faixas de renda mais baixas, conforme assinala a tabela. 
Tabela 04: Total de unidades habitacionais entregues por Federação, conforme a região na faixa 1.

\begin{tabular}{lrrrr} 
Área representativa & $\begin{array}{c}\text { Até } \mathbf{4 1 9} \\
\text { unidades }\end{array}$ & $\begin{array}{c}\text { De } 420 \text { a } 960 \\
\text { unidades }\end{array}$ & $\begin{array}{r}\text { 961 unidades } \\
\text { ou mais }\end{array}$ & Total \\
\hline Regiáo Norte & 5.015 & 7.470 & 8.567 & 21.052 \\
Regiáo Nordeste & 19.659 & 30.957 & 41.167 & 91.783 \\
Maranháo & 1.753 & 4.864 & 7.942 & 14.559 \\
Piaui & 2.576 & 3.082 & 4.293 & 9.951 \\
Ceará & 2.409 & 2.467 & 1.280 & 6.156 \\
Rio Grande do Norte & 910 & 3.942 & 2.083 & 6.935 \\
Paraíba & 244 & 584 & 1.240 & 2.068 \\
Pernambuco & 2.210 & 1.847 & 2.396 & 6.453 \\
Alagoas e Sergipe & 1.743 & 1.404 & 5.116 & 8.263 \\
Bahia & 7.814 & 12.767 & 16.817 & 37.398 \\
Regiăo Sudeste & 27.910 & 26.088 & 21.070 & 75.068 \\
Minas Gerais & 11.541 & 11.462 & 3.991 & 26.994 \\
Rio de Janeiro e Espírito Santo & 3.333 & 4.939 & 7.547 & 15.819 \\
Sáo Paulo & 13.036 & 9.687 & 9.532 & 32.255 \\
Regiăo Sul & 20.977 & 9.306 & 2.709 & 32.992 \\
Paraná & 7.742 & 3.284 & 2.709 & 13.735 \\
Santa Catarina & 4.343 & 2.839 & - & 7.182 \\
Rio Grande do Sul & 8.892 & 3.183 & - & 12.075 \\
Regiăo Centro-Oeste & 7.811 & 8.592 & 7.907 & 24.310 \\
\hline Brasil & 81.372 & 82.413 & 81.420 & 245.205 \\
\hline
\end{tabular}

Fonte: Ministério das Cidades e IPEA. Dezembro de 2012.

Segundo ainda os dados fornecidos pelo Ministério das Cidades e pelo IPEA na tabela ora reproduzida, é possível constatar a baixa atuação do Ceará junto ao PMCMV. Assim que a meta do primeiro milhão de moradias foi atingida no Brasil, o Ceará ocupava uma das piores colocações, se comparado aos números contratados nas demais unidades federadas. Em paralelo à baixa atuação observada, percebe-se que a maioria dos empreendimentos no Ceará, principalmente os relativos à primeira fase do Programa, se concentrou na RMF, como já mencionado. Volta-se, agora, à produção quantitativa nesta região em que são priorizados os municípios de Fortaleza, Maracanaú e Caucaia.

O Ceará representa um dos seis estados que mais concentra o défice urbano na faixa 1, por ordem esses estados são: Maranhão (72\%), Alagoas(72\%), Paraíba (70\%), Pernambuco (70\%), Ceará (70\%) e Bahia (69\%). Analisando a proporção da redução do défice por região do país, Pádua (2015) extraiu a proporção do total de unidades contratadas por cada faixa pelo número do défice urbano de cada faixa, chegando a proporção do défice atendido por cada unidade da federação da região Nordeste. 
Gráfico 07: Proporção do défice no Nordeste, atendidos pelas unidades contratadas.

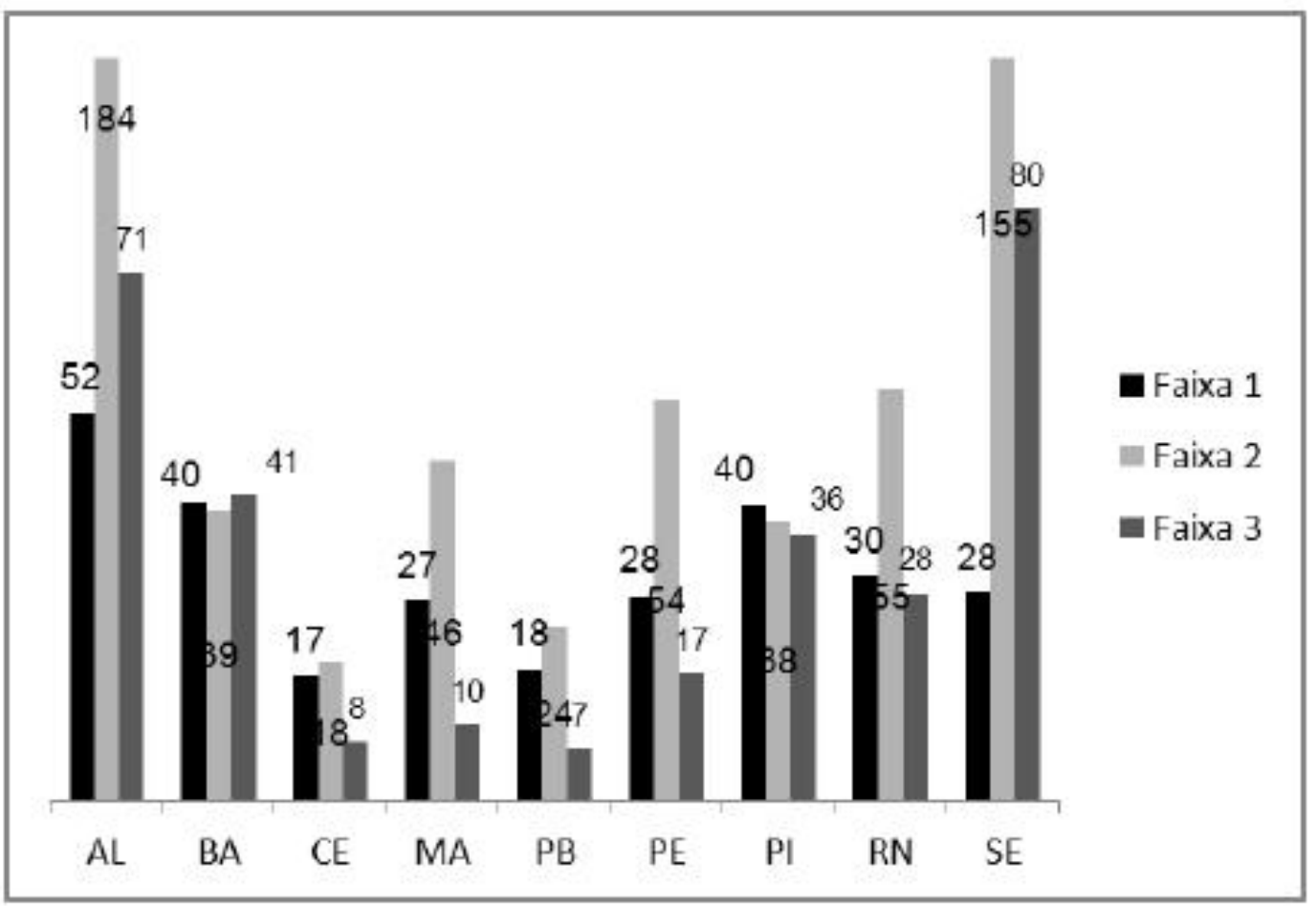

Fonte: Pádua (2015) relação entre os dados da CEF (junho 2014) e dados do défice da Fundação João Pinheiro.

\subsection{A produção em números, os resultados do PMCMV na RMF}

No total de 50.119 UHs contratadas na RMF, evidencia-se uma concentração da produção do Estado na sua Capital. Se considerada, entretanto, a quantidade de domicílios da RMF, esse valor não corresponde a mais de que $5 \%$ do total de seus domicílios.

Ainda que o PMCMV tenha um volume de investimento que impressione; ainda que esse mega programa tenha contratado no Território Nacional em apenas cinco anos de ação quase $80 \%$ das unidades que o BHN financiou durante os seus 20 anos de atuação ${ }^{45}$; ainda que os subsídios deste Programa ampliem o mercado para a baixa renda e ofereça até $96 \%$ do valor financiado, o resultado do PMCMV na RMF tem uma

${ }^{45}$ Fonte: Minha Casa Minha Cidade, avaliação do Programa em seis estados brasileiros. O comparativo aponta que durante o BNH aproximadamente 4,5 milhões de casas, 1/4 da população, foram financiados. O PMCMV até 2014 apresentava 3,5 milhões de unidades contratadas, sendo 1,7 milhão entregue. 
atuação reduzida e isso minimiza, à primeira vista, as influências da sua produção na estruturação da Metrópole.

A análise da produção do PMCMV por municípios do Estado do Ceará reforça a clara concentração de seus empreendimentos na Capital e nos municípios de Maracanaú e Caucaia. Em Fortaleza, tradicionalmente, já se percebia que a habitação para a baixa renda era deslocada, a própria estruturação de Caucaia e Maracanaú remonta a produção dos conjuntos habitacionais construídos pelo $\mathrm{BNH}$.

Tabela 05: Total de empreendimentos da RMF contratados pelo PMCMV (2009 a 2015)

\begin{tabular}{|c|c|c|c|c|c|c|c|c|}
\hline MUNICÍPIO & N. EMP & $\begin{array}{l}\text { POPULAÇÃO } \\
\text { MUNICIPIO }\end{array}$ & $\begin{array}{c}\text { TOTAL DE } \\
\text { DOMICÍLIOS }\end{array}$ & $\begin{array}{c}\text { TOTAL DE } \\
\text { UHS }\end{array}$ & \begin{tabular}{|c|}
$\%$ UHS \\
POPULAÇÃO
\end{tabular} & FAIXA 1 & FAIXA 2 & FAIXA 3 \\
\hline AQUIRAZ & 3 & 72.628 & 19.662 & 432 & $2,20 \%$ & 432 & & \\
\hline CASCAVEL & 1 & 66.142 & 18.806 & 209 & $1,11 \%$ & 209 & & \\
\hline CAUCAIA & 36 & 325.441 & 89.183 & 7.156 & $8,02 \%$ & 6.556 & 568 & 32 \\
\hline CHOROZINHO & 1 & 2.452 .185 & 709.952 & 312 & $0,04 \%$ & 312 & & \\
\hline EUSÉBIO & 1 & 209.057 & 57.895 & 74 & $0,13 \%$ & & & 74 \\
\hline FORTALEZA & 114 & 2.452 .185 & 709.952 & 35.538 & $5,01 \%$ & 25.777 & 6.422 & 3.339 \\
\hline HORIZONTE & 5 & 72.299 & 18.726 & 991 & $5,29 \%$ & 936 & 55 & \\
\hline ITAITINGA & 1 & 43.890 & 12.000 & 176 & $1,47 \%$ & 176 & & \\
\hline MARACANAÚ & 12 & 209.057 & 57.895 & 4.401 & $7,60 \%$ & 4.145 & & 256 \\
\hline MARANGUAPE & 4 & 113.561 & 28.995 & 934 & $3,22 \%$ & 934 & & \\
\hline PACAJUS & 6 & 61.838 & 17.587 & 1.180 & $6,71 \%$ & 1.180 & & \\
\hline PACATUBA & 15 & 72.299 & 18.726 & 2.673 & $14,27 \%$ & 940 & 1.733 & \\
\hline GUAIÚBA & & 24.091 & 6.397 & 0 & $0,00 \%$ & & & \\
\hline PINDORETAMA & & 18.683 & 5.353 & 0 & $0,00 \%$ & & & \\
\hline SÃO GONÇALO & 1 & 43.890 & 12.000 & 499 & $4,16 \%$ & 499 & & \\
\hline SÃO LUIS DO CURU & 2 & 12.332 & 3.579 & 90 & $2,51 \%$ & 90 & & \\
\hline TRAIRI & 2 & 51.422 & 13.338 & 442 & $3,31 \%$ & 442 & & \\
\hline TOTAL & 204 & 6.301 .000 & 1.800 .046 & 55.107 & $3,06 \%$ & 42.628 & 8.778 & 3.701 \\
\hline
\end{tabular}

$\mathrm{Na}$ análise específica dos dados da RMF verificam-se duas questões distintas: a dificuldade encontrada em adquirir terrenos para a contratação na faixa 1 e uma aparente dificuldade na formação de mercado para as faixas 2 e 3, tendo a produção para essas faixas de renda uma escala ainda mais reduzida. As explicações poderiam ser pensadas pela ordem do consumo, uma vez que as cidades do Nordeste com economia mais empobrecida não formariam demanda solvente para as faixas intermediárias do PMCMV, sendo atendidas pelo próprio mercado tradicional; ou as respostas passariam pela ordem da produção, entendendo que o interesse do setor da construção civil, em Fortaleza, se confunde com o próprio setor imobiliário. Em razão do peso da construção civil nesta Metrópole, pondera-se se não seria mais vantagem 
para este setor a produção da faixa 1, uma vez que responde melhor às características do mercado local. Nota-se, aqui, com efeito, que a estrutura das empresas da construção civil se identifica com o 'módus operandi' da produção para a faixa 1, o que poderia ser uma das explicações para a realidade específica da produção nesta Cidade. A própria atuação das empresas locais junto aos anteriores programas habitacionais, notadamente o PAR, em Fortaleza, demonstra o interesse do setor na produção de unidades habitacionais. Vale destacar ainda que a etapa de comercialização e venda de unidade inexistia no PAR, sendo seus ganhos advindos da organização do projeto e da obra em si.

Mesmo considerando, porém, o alto índice de contratações voltadas para a faixa 1 , percebe-se que essas são muito aquém das expectativas previstas pelo PMCMV. A explicação desses resultados, necessariamente, passa pela questão fundiária. O resultado insatisfatório do PMCMV na RMF tem como justificativa a aquisição de terrenos compatíveis com as exigências de infraestrutura requisitadas pelo Programa. Da parte dos construtores, corretores e agentes do mercado imobiliário, o comentário é que os terrenos dotados de serviços urbanos requeridos pelo PMCMV se localizam em áreas valorizadas cujo preço inviabiliza a produção de uma unidade habitacional nos limites estabelecidos.

Então, o que é que aconteceu? A escassez de terrenos fez com que os preços subissem muito. MCMV tem um parâmetro, então você não pode comprar o terreno muito caro porque não vai ter como retornar esse dinheiro para o agente financeiro que é a CEF. Então, o que eu vi com relação a terrenos foi praticamente isso: a escassez de terrenos urbanos e, imediatamente, a elevação dos preços deles por causa do impulso do $\mathrm{PMCMV}^{46}$.

Nota-se, numa mesma afirmação, o aumento especulativo do valor da terra com o lançamento do PMCMV e a percepção de uma escassez de terrenos viabilizados para o Programa: terrenos grandes, infraestruturados com preços compatíveis com os valores estabelecidos pela CEF. Por outro lado, o mercado enxerga ampla disponibilidade de terrenos nos municípios vizinhos a Fortaleza. É nesses municípios onde se realiza o grande número de condomínios para a faixa 1 , que, possuem condições ainda mais precárias de infraestrutura urbana. Passa pelo valor da terra a

${ }^{46}$ Entrevista realizada com corretor do Secovi, expertise em loteamentos e terrenos, em 2015. 
justificativa dessa decisão, assim como transitam pelo interesse e envolvimento dos municípios a viabilização e a contratação desses empreendimentos para a baixa renda.

A entrada de grande recurso financeiro sem garantir o controle e o planejamento do uso do solo fez com que o aumento da especulação e a renda fundiária se ampliassem em uma valorização percebida nacionalmente. Grandes volumes de recursos foram absorvidos pelos preços dos terrenos e os aportes públicos foram absorvidos pela renda da terra. O modelo do PMCMV desenhado e entregue para as construtoras fortaleceu a ideia de que a terra é somente um negócio, não passa pela ideia de inclusão social, crescimento urbano e direito à cidade - a terra tem relação com lucro na óptica do mercado imobiliário.

Nessa circunstância, na qual o mercado imobiliário tem papel determinante nas regulações e na coordenação do uso social da base fundiária, em um crescente de preços que se valorizam, questiona-se onde foram produzidos os estoques habitacionais do PMCMV durante as duas etapas em que essa política não só esteve desassociada da política urbana, mas, aliada às dinâmicas dos negócios imobiliários. 


\subsection{A Localização dos empreendimentos}

As relações espaciais geradas pelos estoques residenciais produzidos pelo PMCMV na RMF podem ser melhores observadas no mapa a seguir. Mapa 06: Localização de empreendimentos aprovados junto ao PMCMV (2009-2015)

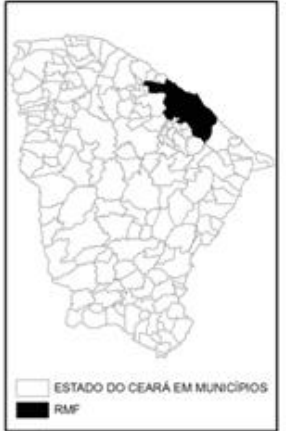

CONTRATOS FaIXA 1

CONTRATOS FaIXA 2

CONTRATOS FAIXA 3

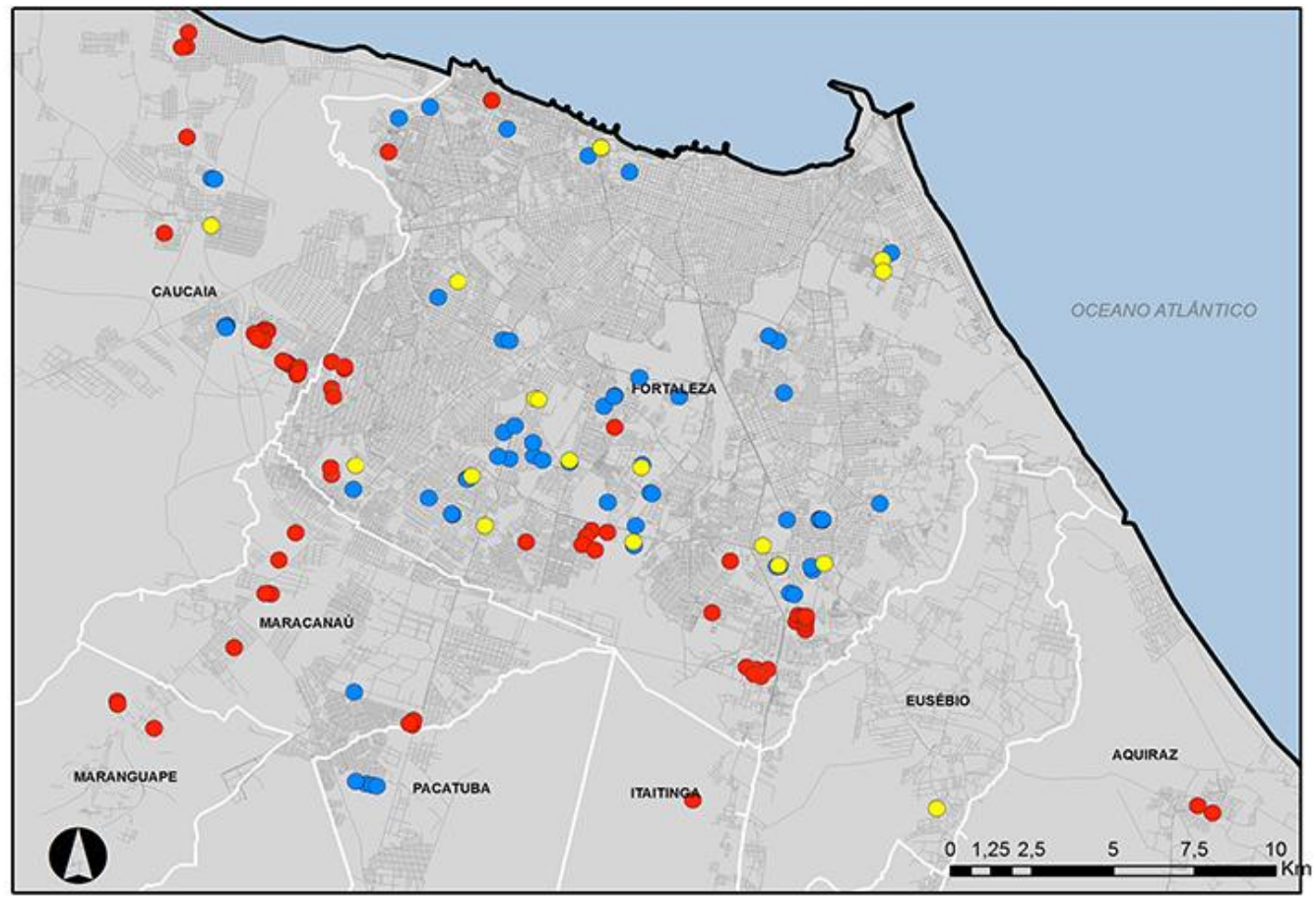

Fonte: Atualização base LEHAB, dados do Ministério das Cidades até março de 2015.

É notório que a densidade e o porte dos empreendimentos não aparecem no mapa, o que se pode observar é a aglutinação da contratação de implementos em terrenos contíguos. A análise efetivada diferenciou as faixas de renda e observou que a variação das relações espaciais entre cada um deles, seja nos municípios em que se localizam ou nos bairros quando associados à Fortaleza, define uma escolha de localização que designa a faixa de renda relacionada com o valor do terreno, a distância centro-periferia e a infraestrutura.

É visível em Fortaleza a concentração de condomínios das faixas 2 e 3, em sua maior parte nos bairros pericentrais e intermediários, enquanto os da faixa 1 se mostram ocupando as margens do limite do Município, espaços periféricos e se disseminam em maior número de contratos nos municípios conurbados à Capital. 
Observa-se, ainda, que as duas maiores aglutinações de contratos junto à faixa 1 em Fortaleza dizem respeito ao Conjunto Cidade Jardim (com 5.563 unidades) e ao Residencial Luiz Gonzaga (com 3.520 unidades), ambos contratados com parceria do Governo do Estado e da Prefeitura de Fortaleza nos bairros de José Walter e Ancuri, respectivamente. No momento de seus lançamentos, foram anunciados como os maiores empreendimentos do PMCMV na região Nordeste ${ }^{47}$ e os maiores junto ao Programa Entidades ${ }^{48}$.

Figura 03: Implantação e foto aérea do Conjunto Cidade Jardim em Fortaleza
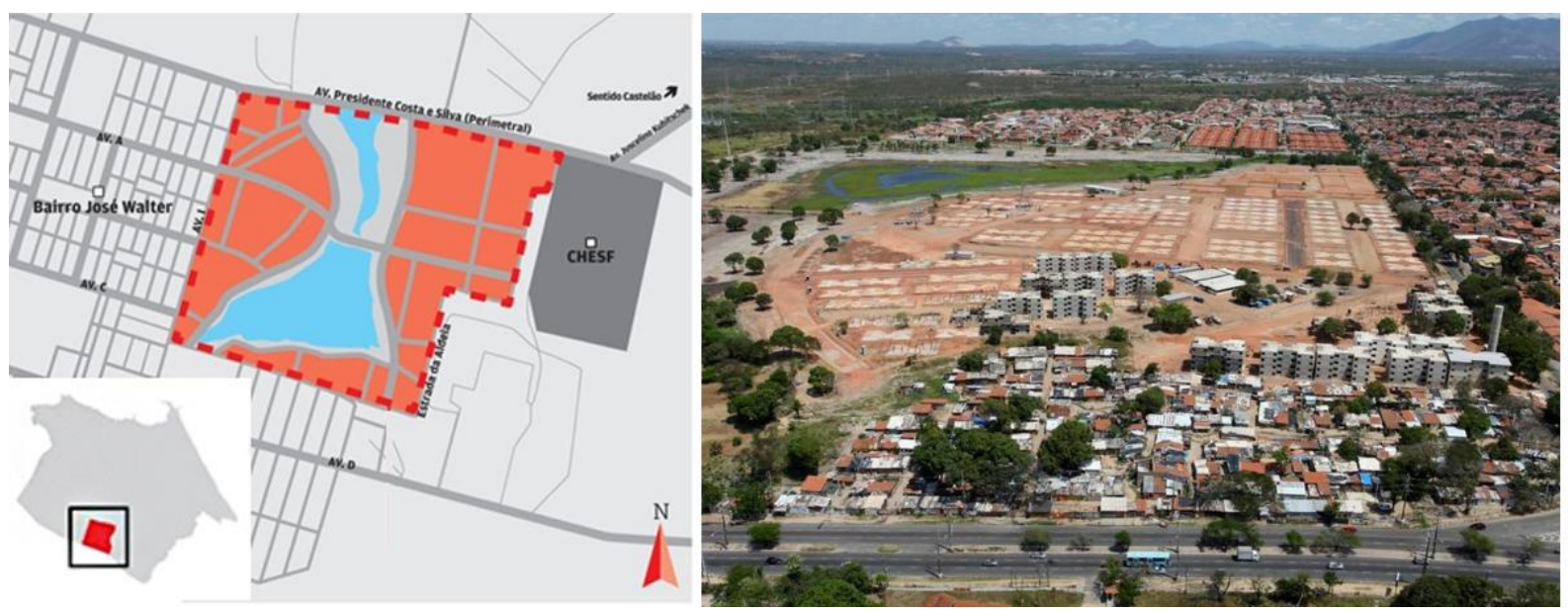

Fonte: Mapeamento e Fotografia retirados do jornal o povo, em 2014.

O porte e a dinâmica da contratação desses empreendimentos inauguram um movimento da retomada dos implementos dos grandes conjuntos habitacionais. Essa atividade não é conduzida sem a participação do Estado; ao contrário, a contratação desses grandes projetos está associada à concentração de esforços dos governos estadual e municipais nas ações empreendidas com recursos do PAC Moradia com vistas às opções habitacionais decorrentes das remoções das obras da Copa do

\footnotetext{
${ }^{47}$ Consultar site do PAC: http://www.pac.gov.br/noticia/e00cadb7 ."Fortaleza (CE) contará com o maior empreendimento do Programa Minha Casa, Minha Vida no estado do Nordeste. O Residencial Cidade Jardim, que teve a Ordem de Serviço para construção(...) terá 5.536 apartamentos. O Residencial Cidade Jardim só perde em grandeza para o empreendimento que está sendo construído em Manaus, que contará com nove mil moradias."

${ }^{48}$ Notícia no site da secretária de habitação: ttp://www.fortaleza.ce.gov.br/noticias/habitafor/prefeituraassina-contrato-para-construcao-do-maior-residencial-do-mcmv-entidades. O residencial Luiz Gonzaga terá duas etapas, totalizando 3.520 unidades habitacionais, no bairro Ancuri, sendo o maior do Brasil. A primeira etapa terá 1.760 unidades e investimento de R\$ 128,5 milhões oriundos do Governo Federal/Minha Casa, Minha Vida e aporte da Prefeitura de Fortaleza. Para a construção do Residencial três organizações não-governamentais se uniram: Federação das Entidades de Bairros e Favelas de Fortaleza, Cearah Periferia e Associação Habitat para a Humanidade."
} 
Mundo. Com exceção dessas grandes aglomerações de contratos advindos da retomada de empreendimentos de maior porte, nota-se uma concentração dos empreendimentos na faixa 1 dos municípios contíguos a Fortaleza, onde se avança o deslocamento do adensamento de lotes populares e de conjuntos habitacionais tradicionais, assim como de indústrias que migram para esses municípios periféricos.

É possível ainda observar certa disposição espacial para que os empreendimentos contratados da faixa de baixa renda se situarem na porção oeste da RMF, enquanto das faixas de renda mais alta se localizarem no hemisfério leste da ocupação urbana.

As diferenças entre leste e oeste são reforçadas, revelando a dicotomia de renda e adensamento demográfico nesses distintos espaços urbanos. Essa disposição avigora a ideia da desigualdade na produção do espaço da RMF, onde a noção dual entre centro e periferia também assume a feição da diferença de valor, investimento, infraestrutura e significados na dualidade leste e oeste.

Algumas análises dividem Fortaleza, como já citado, desde seu Centro, tendo a BR 116 como divisor de áreas, em duas cidades: uma pobre, do Oeste; e outra, rica, do leste. A cartografia da Metrópole exprime, portanto, oposições entre bairros onde moram pessoas de rendas diferentes, que podem ou não ter acesso aos serviços e aos equipamentos sociais de boa qualidade. A zona oeste, que tem solo impermeável, elevado lençol freático e carência de infraestrutura, exibe elevada densidade de população de baixa renda. Na zona leste, com melhores condições de solo e infraestrutura, estão alçadas concentrações de população com renda média e alta (PMF, 1992, p.13).

Percebe-se, portanto, em Fortaleza as especificidades de seus arranjos produtivos em suas relações de poder, e demonstra como esses segmentos sociais se posicionam no espaço. A disposição espacial entre leste e oeste reforça a ideia da desigualdade na produção do espaço da RMF, onde a noção dual entre centro e periferia assume feição da diferença de valor de investimento, infraestrutura e significados dessa dualidade.

Mapa 07: Espacialização dos padrões de valores dos terrenos em Fortaleza 


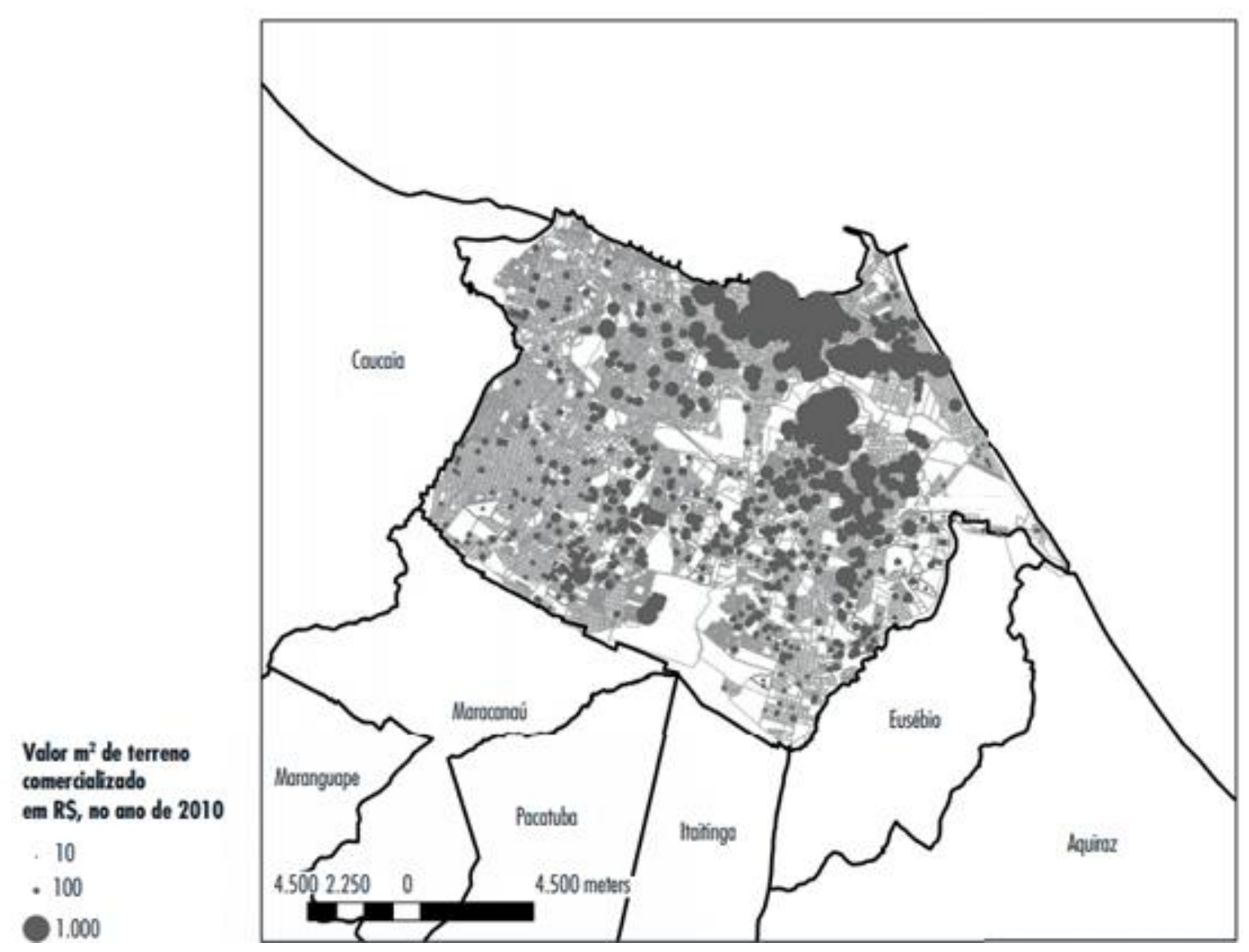

Fonte: FREITAS (2014), mapeamento elaborado sob-base de dados do Imposto de Transmissão de Bens Intervivos - ITBI.

Observam-se nas escolhas dos terrenos da Metrópole características que se repetem na organização social das faixas de renda, assim como repercussões que ensejam novas localizações. Notam-se novas frentes de expansão do setor imobiliário, outrora encerradas nos bairros mais infraestruturados e de maior valorização imobiliária que passam a ganhar novas dinâmicas e contornos. As faixas de rendas de três a dez salários-mínimos avançam na busca de lotes com preços mais baixos em áreas mais periféricas, como oportunidades a serem exploradas pelo mercado imobiliário. O incentivo à aquisição da casa própria e o grande volume de crédito associado à procura por novas áreas de valorização possibilitaram o avanço de camadas médias para terrenos antes rejeitados por esse mercado.

Por outro lado, essa mesma frente de valorização e readensamento de áreas mais periféricas e descontínuas de urbanização impeliu a produção das faixas de renda mais baixas para os bairros onde não se viam oportunidades de valorização. Constituem bairros precários oriundos de loteamentos populares, conjuntos 
habitacionais e favelas que passam por intenso processo de adensamento, evidenciando a segregação quando os beneficiários das rendas mais baixas permanecem privados ao acesso de serviços da Cidade.

\subsubsection{Dinâmicas de localização para o mercado de três a dez salários-mínimos}

O movimento associado entre as faixas de renda e as escolhas de localização aproxima do referencial discutido por Abramo (2007), em que propõe uma análise sobre a configuração residencial desde a produção de estoques de habitações por parte dos empresários urbanos.

O autor considera não somente a dimensão econômica, mas também a própria dimensão das escolhas das pessoas. Essa compreensão traz ao mercado uma dinâmica de interdependência das escolhas de localização, uma vez que os trabalhadores escolhem morar com suporte na busca de "externalidades" ou "proximidades" com as famílias de renda mais elevadas, aos conceitos que são situados como valorizados pelo mercado imobiliário.

O empresário urbano, na sua concepção, é o agente que sinaliza as mudanças na dinâmica imobiliária e assume duplo papel. É o profissional da antecipação urbana, que, assumindo os riscos e agindo à frente de outros empresários, emite sinais para os demais produtores, na medida em que elege novas frentes e áreas para apropriação. É também o empresário que produz novos tipos de imóveis nessas novas localizações, extraindo valores dessas inovações espaciais.

Consoante, ainda, Abramo (2007), essa inovação espacial consiste na produção de imóveis com diferenciações para atrair famílias de alta renda para novas localizações. Ao deslocar essa faixa de renda, seus interesses criam outra "ordem urbana" onde convergem negócios que atraem grupos sociais semelhantes e estabelecem uma nova convenção urbana.

Esses saltos por novas localidades, que ao mesmo tempo provocam fragmentação e difusão do mercado, foram seguidos por um movimento de concentração, estabelecendo novos centros de valorização imobiliária em atividades sucessivas que marcam a história dos estoques residenciais na Cidade por meio das consecutivas convenções urbanas dirigidas pelo mercado imobiliário. 
Como visto em seções anteriores, a atuação da faixa 2-3 se assemelha com a atividade de produção de mercado onde a empresa proponente possui liberdade para conceber as características do projeto e criar as próprias estratégias de comercialização. Desta maneira, se torna possível lucrar com a diferença entre o valor pago pelo terreno e pelo novo valor criado, uma vez que as regras de aquisição mudam.

Com efeito, a construção para os segmentos de 3 a 10 salários-mínimos é bem semelhante ao processo de incorporação focado para as famílias que auferem renda superior a dez salários-mínimos, com a exceção de que o PMCMV estabelece valores máximos fixos das unidades vendidas, vetando às empresas vendê-las mais caras do que o estabelecido, exigindo estratégias de racionalização de custos para a obtenção do almejado lucro.

O reforço para produzir da habitação para os segmentos populares trouxe diversas novas empresas para atuar na Metrópole, assim como outras estratégias e inovações foram observadas por empreendimentos que se diferenciavam e apontavam para o direcionamento em bairros ainda pouco explorados, consoante mostra melhor o mapa a seguir. 

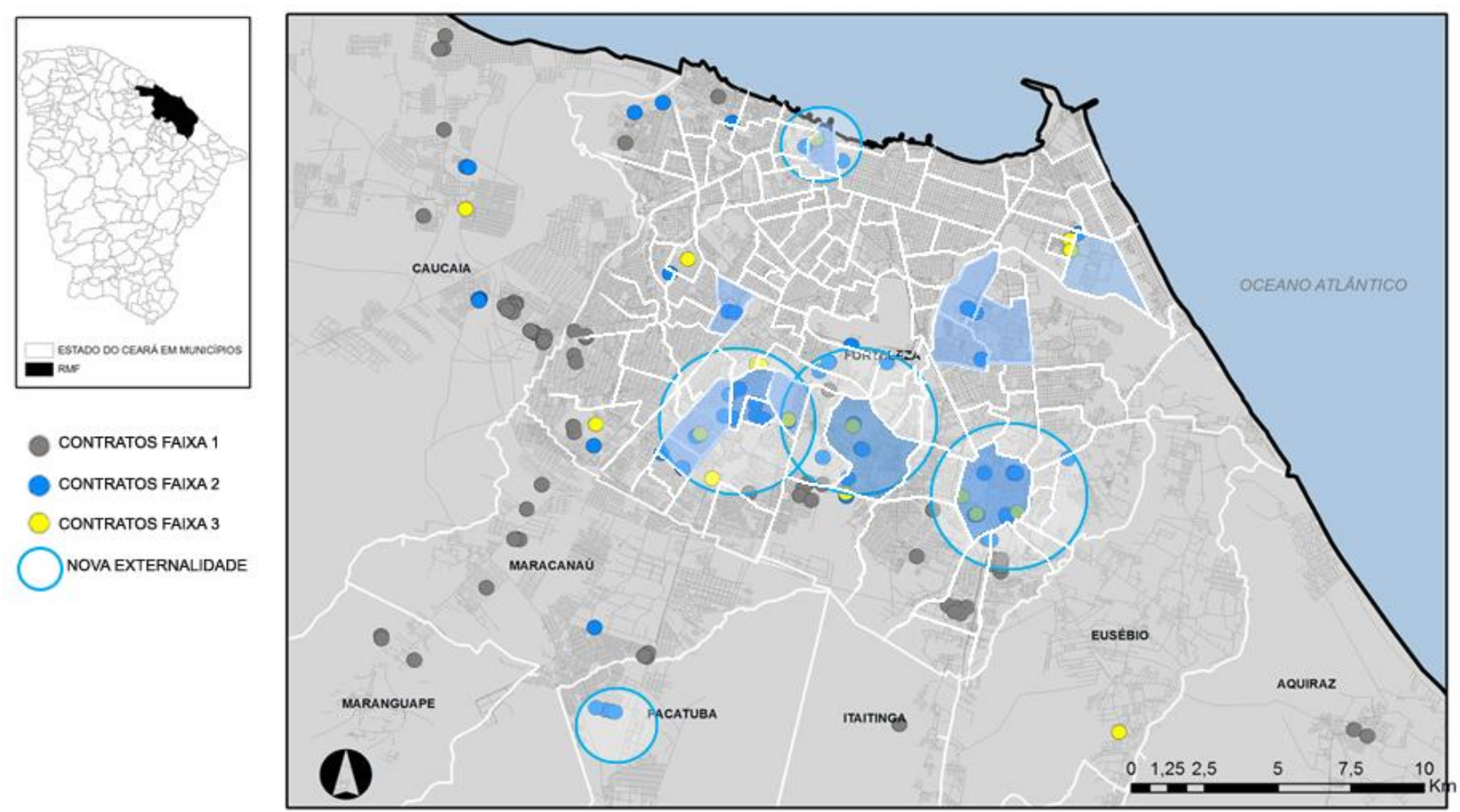

Fonte: Edição própria, com suporte na atualização do mapa do LEHAB.

Observa-se que as imediações dos bairros Messejana, Passaré, Maraponga, Mondubim, Parangaba e Dias Macêdo são amplamente exploradas para esses segmentos de renda. Verifica-se, inclusive, certa equalização das regiões no nome de um determinado bairro. Alguns lançamentos, apesar de se situarem em bairros contíguos ao citado, vinculam-se à localização de bairros mais valorizados como estratégia de marketing para a sua comercialização, fortalecendo a ideia de elaboração de externalidades nas apropriações de nomes e imaginários que passam a se constituir sobre cada uma dessas regiões.

O aumento significativo nos valores dos terrenos que ainda exprimem condições aproveitáveis de infraestrutura e melhor ligação com o centro da Metrópole se acentuam nas imediações do lançamento do Programa. Em um crescente que desponta em alguns desses bairros, cita-se o Passaré ${ }^{49}$ como recordista de lançamento e vendas, segundo dados do Sinduscon-CE; além de Messejana, que por seguidos anos desponta como um dos dez bairros que mais vendeu imóveis em Fortaleza. Percebese, portanto, que há uma importante inversão de papéis, pois, bairros que antes

\footnotetext{
${ }^{49}$ Segundos dados do Sinduscon-CE, Passaré foi o bairro que apresentou recordes de dinâmica imobiliária, despontando em primeiro lugar em 2014.
} 
concentravam baixa atividade imobiliária ultrapassam o crescimento de vendas daqueles que tradicionalmente concentravam os interesses imobiliários, conforme pode ser bem evidenciado no gráfico abaixo.

Gráfico 08: Lançamentos de unidades por bairro em Fortaleza 2004-2012

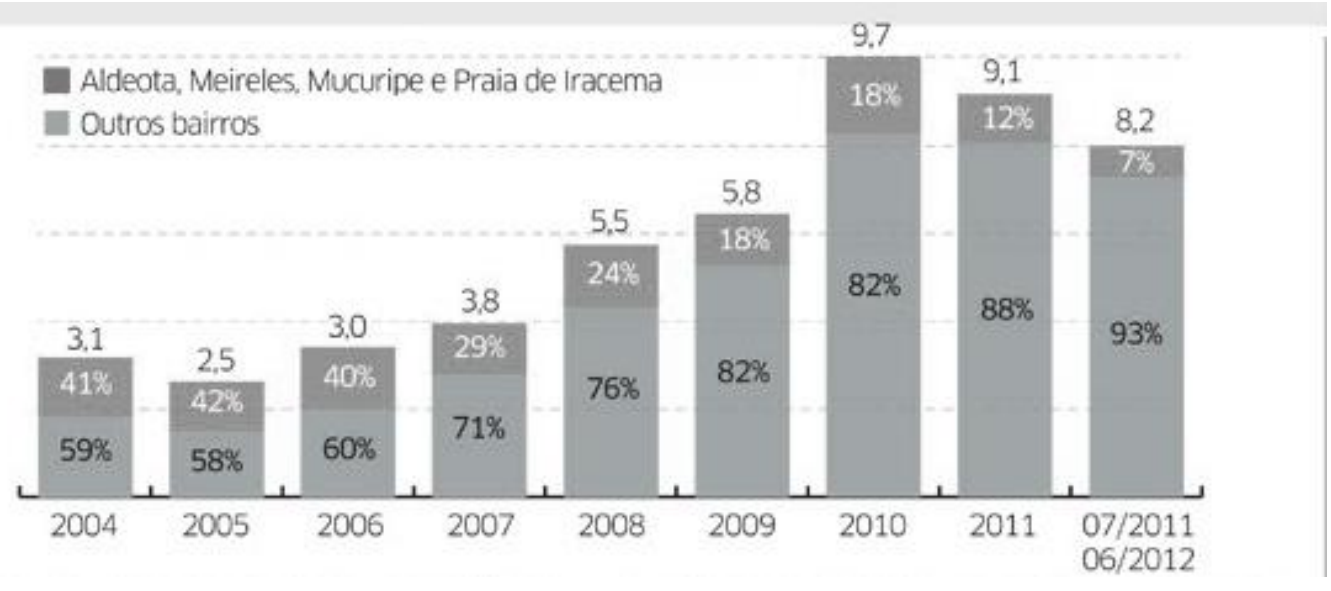

Fonte: Instituto de Pesquisa e Estatística Secovi-CE (Inspece)

Nota-se que houve aumento no reforço da produção imobiliária em toda a Metrópole. O incremento de novas unidades habitacionais é crescente e disparou justamente no ano do lançamento do PMCMV, em 2009. Antes, a atividade imobiliária formal de Fortaleza se concentrava em bairros valorizados - Aldeota, Meireles e Praia de Iracema - representando nada menos do que $40 \%$ de todos os empreendimentos lançados. Gradativamente, essa atividade demonstra se diluir em outros bairros e novas frentes de expansão são formadas, como revela o gráfico apresentado.

Rufino (2012) discute a valorização da metrópole Fortaleza e a alteração do patamar dos preços de seus imóveis justamente no fortalecimento da atuação das grandes empresas imobiliárias que, desde o ano de 2005, expandiam seus negócios com o lançamento do PMCMV. De fato, afirma a autora, conquistaram a estrutura para ampliar suas frentes de mercado em direção a um público de baixa renda.

Observa-se que desde 2007, as estratégias imobiliárias parecem tomar novos rumos, apropriando-se de outros espaços da Metrópole, anteriormente não ocupados. O próprio movimento de centralização de capital provocado com as chegadas de grandes construtoras e incorporadoras, como já discutido neste trabalho, representa o que Abramo (2007) chama de "profissional da antecipação", aquele que dá os 
primeiros sinais e define as novas localizações e os movimentos de valorização imobiliária.

De maneira geral, esse processo é seguido e tende a influenciar toda a mobilidade da produção imobiliária, conduzindo uma dinâmica própria em uma "ordem de mercado" que tem como característica esses contínuos movimentos. A diferenciação e inovação tem como resultado, e mesmo fim, a elevação dos preços dos imóveis e da terra em determinados espaços da Metrópole.

A procura por terrenos levou as construtoras com porte e estrutura capitalizada a adquirirem terrenos em áreas de zona de expansão já próximas das bordas do município de Fortaleza. A existência de amplos terrenos remanescentes de antigos loteamentos ou de desocupação de glebas com antigo uso industrial ou rural passou atrair os olhares dos corretores e das grandes empresas. Embora as possibilidades de adensamento fossem menores do que as das demais regiões, esses grandes terrenos permitiram a produção de grandes condomínios e favoreceram as apropriações em larga escala.

Essa situação se tornou evidente em alguns bairros que passaram a concentrar grandes condomínios multifamiliares que contrastavam com seu padrão de uso do solo de pequenas casas unifamiliares e condomínios de pequeno porte.

A inovação espacial foi seguida por um expressivo aumento nos preços da terra de cada uma dessas espacialidades. O aumento do valor do metro quadrado não deve ser entendido somente como causa da intensa valorização dos imóveis do mercado da região, como explica o mercado imobiliário, e, sim, como consequência dessas estratégias espaciais.

Com respaldo em Rufino (2012), destaca-se que, no caso de Messejana, sua valorização começa antes mesmo da transformação espacial do bairro. Essa valorização tem início há cerca de dois anos, quando um amplo volume de terrenos foi comprado na região por preços mais baratos no afã das grandes empresas montarem seus bancos de terra. Essa estratégia é condição essencial para o planejamento da viabilização dos negócios e a ampliação dos lucros e se tornou lugar-comum nas práticas das grandes empresas com capital suficiente para a formação desses bancos.

Os casos de Messejana, Passaré, Parangaba, Maraponga, Henrique Jorge, Mondubim e outros bairros no entorno marca um movimento de readensamento de 
áreas urbanas mais periféricas deixadas pelos contínuos saltos do processo de urbanização. Nessas grandes áreas, foram implementados conjuntos residenciais para o segmento popular do PMCMV e a valorização dessas áreas marca um crescimento sem igual na Metrópole. Alguns nomes desses bairros são citados como recordistas de lançamentos de empreendimentos durante os anos de atuação do PMCMV, demonstrando a apropriação seletiva desses bairros na descrição dos produtos para as faixas 2 e 3 , conforme se pode ver no mapa seguinte.

Mapa 09: Comportamento dos bairros e lançamentos do mercado em 2014

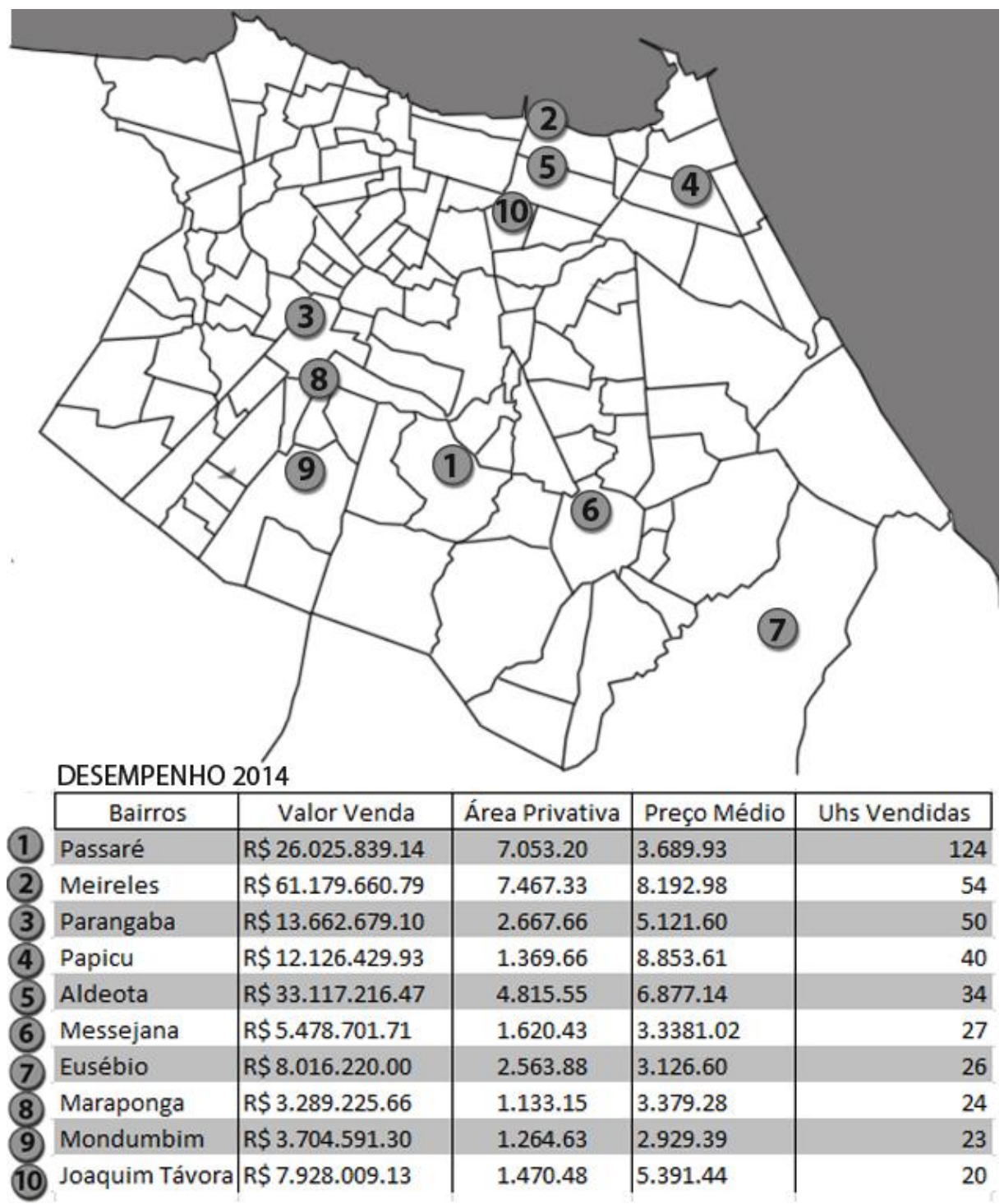

Fonte: Relatórios dos IVV( Índice de Velocidade de Vendas) do Sinduscon- CE, publicado em jornal O Povo. Edição própria.

O gráfico seguinte, compilado do relatório do Sinduscon-CE referente aos indicadores da RMF do mês de dezembro de 2015, descreve os bairros com maior 
número de unidades comercializadas. Os dados nele apresentados confirmam a hipótese de ativação do mercado em bairros ainda não apropriados pela dinâmica imobiliária. Os bairros periféricos no município de Fortaleza continuam despontando um alto índice de venda e a atividade imobiliária no bairro Curicaca, município de Caucaia, aparece entre os seis bairros que mais comercializaram unidades habitacionais.

Gráfico 09: Seis bairros com maior número de UHS comercializadas e valores $\mathrm{m}^{2}$.

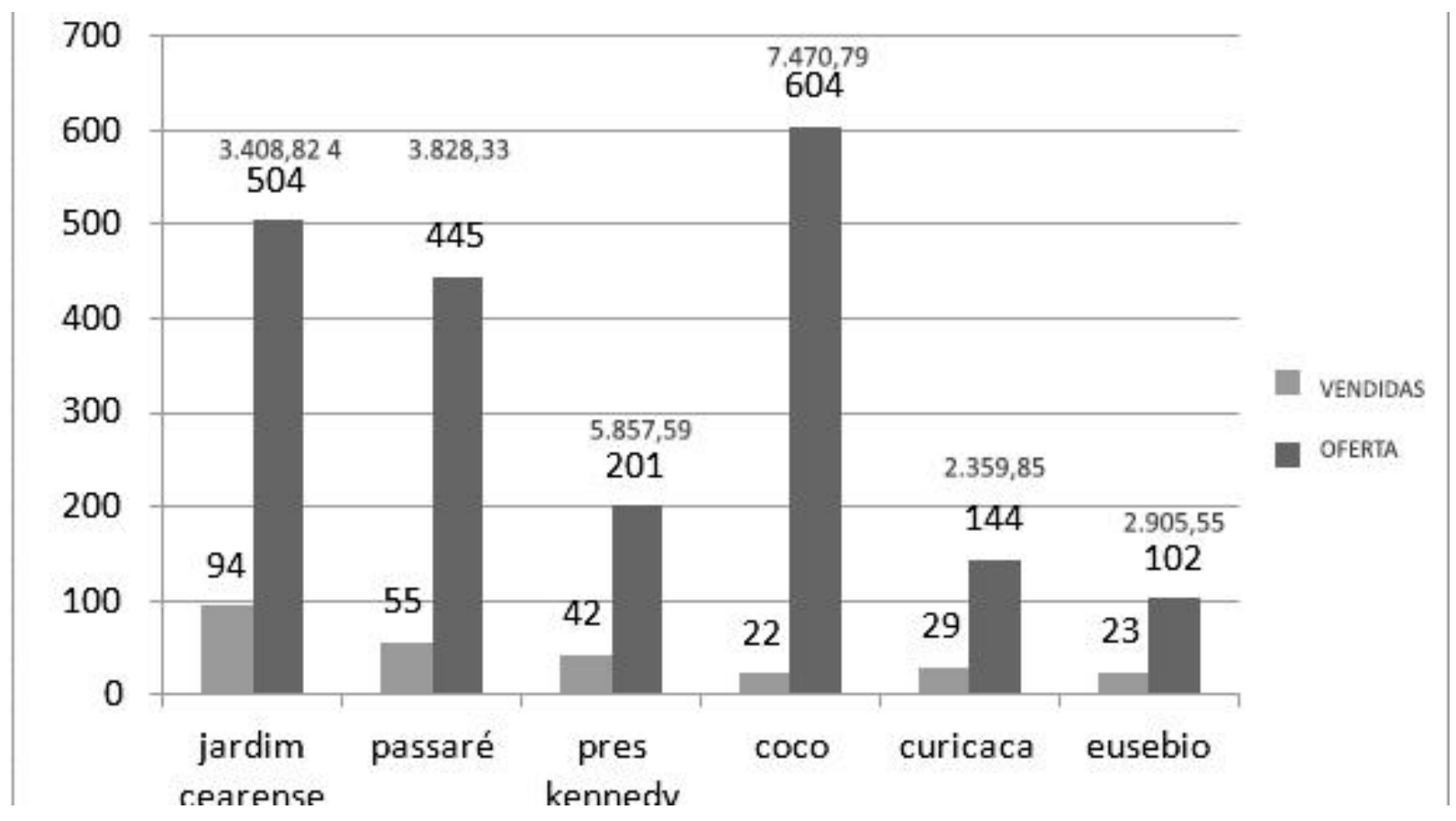

Fonte: Relatório de indicadores do Sindunscon-CE, Dezembro 2015. Organização própria.

Apesar de usar dados do setor imobiliário que exibem algumas limitações, esses instrumentos são ainda uma das poucas fontes de recursos de monitoramento das transformações ocorridas na produção imobiliária do espaço. Por meio deles, podem-se observar as transformações de preços como meio de viabilizar uma leitura temporal que se materializa em diversos centros de valorização da Metrópole. Para melhor percepção destas transformações, o gráfico a seguir apresenta a evolução dessa valorização utilizando-se de um recorte no período de julho de 2008 a janeiro de 2016 em quatro bairros distintos de Fortaleza: Passaré, Parangaba, Maraponga e Messejana 
Gráfico 10: Evolução do valor $\left(\mathrm{m}^{2}\right)$ nos bairros Passaré, Parangaba, Maraponga e Messejana.

variaçăo do preço do $\mathrm{m}^{2}$

apartamento, passare, venda, $n^{\circ}$ de quartos indiferente

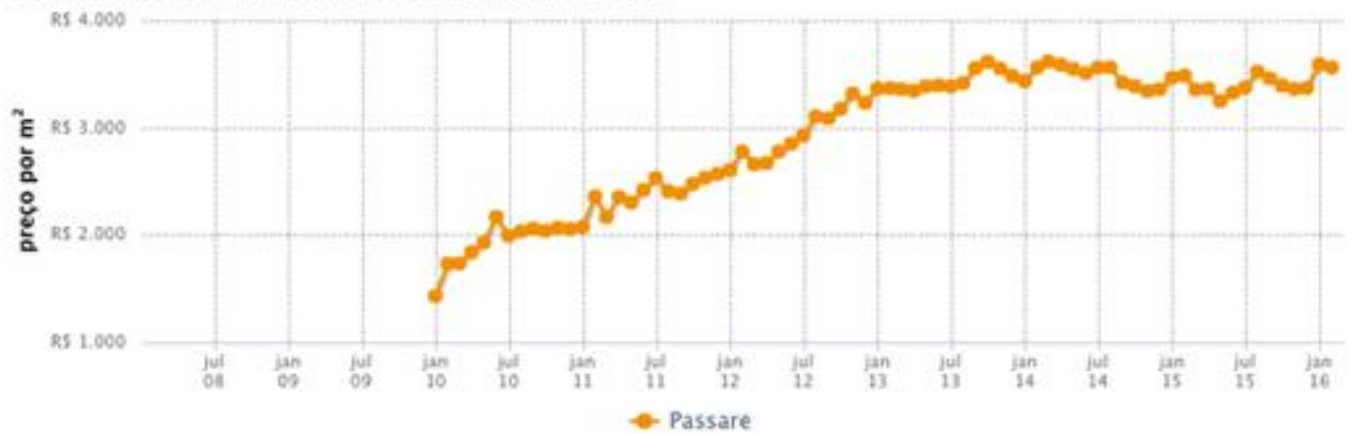

variaçăo do preço do $\mathrm{m}^{2}$

apartamento, maraponga, venda, $n^{\circ}$ de quartos indiferente

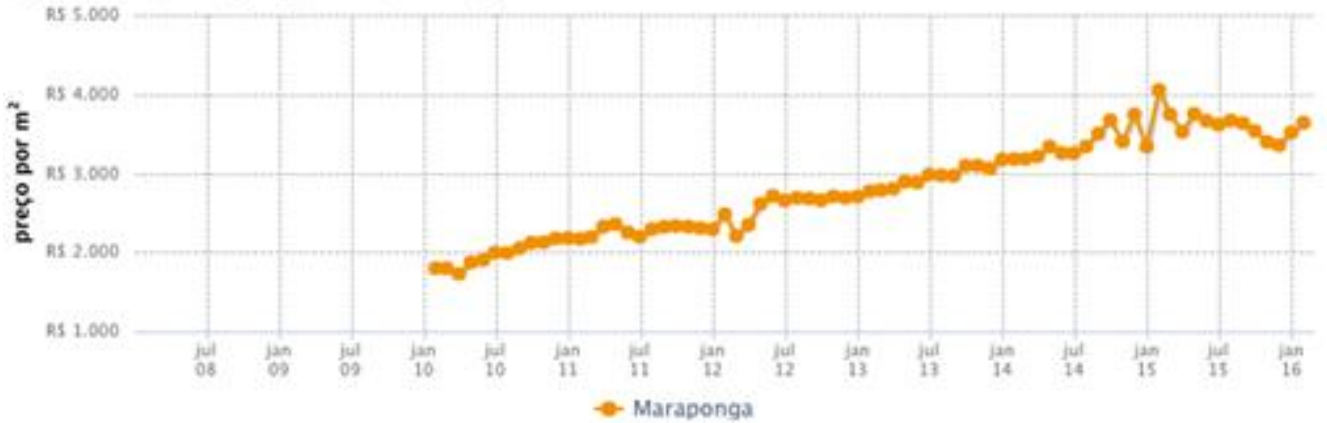

variaçăo do preço do $\mathrm{m}^{2}$

apartamento, parangaba, venda, $\mathrm{n}^{\circ}$ de quartos indiferente

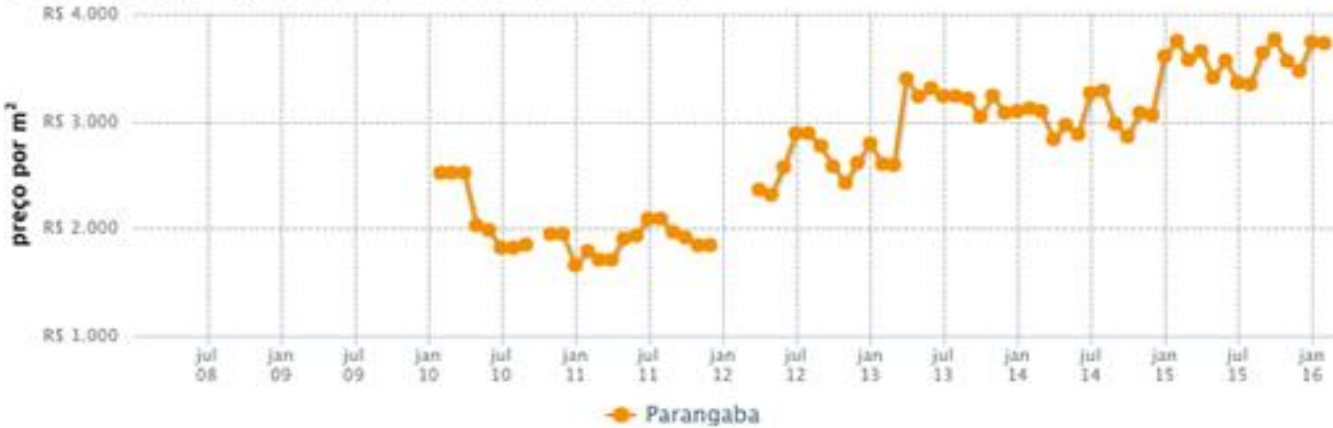

variaçăo do preço do $\mathrm{m}^{2}$

apartamento, messejana, venda, $n^{\circ}$ de quartos indiferente

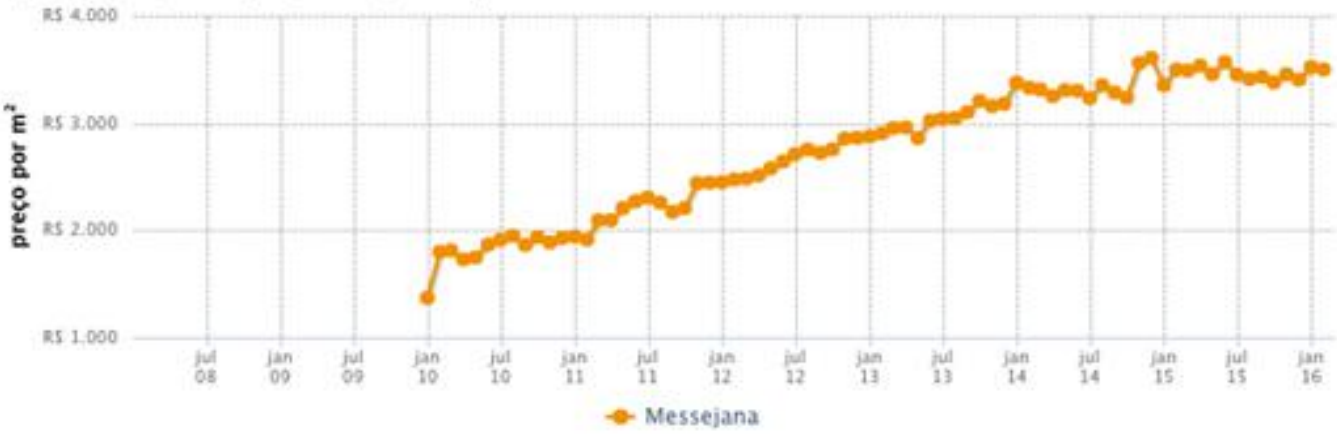

Fonte: FipeZape, dados coletados em janeiro de 2016. 
Sobre as empresas contratantes junto às faixas 2 e 3 na RMF, foi possível observar que a distribuição dos empreendimentos em Fortaleza aponta para a concentração dos recursos em algumas empresas. Ainda que haja 11 empresas contratantes, duas delas se responsabilizam por $74 \%$ do total de unidades habitacionais. A Época Engenharia se especializa na faixa 1 e a sua parceira, Magis/MRV, produz para as faixas 2 e 3 , conforme pode ser visto na tabela abaixo.

Tabela 06: Empreendimentos contratados junto à metrópole de Fortaleza na etapa I - 2009-2011

\section{FORTALEZA}

\begin{tabular}{|c|c|c|c|c|c|}
\hline EMPRESA & N. EMP & $\begin{array}{c}\text { TOTAL DE } \\
\text { UHS }\end{array}$ & FAIXA 1 & FAIXA 2 & FAIXA 3 \\
\hline ECB EGENHARIA & 1 & 168 & 168 & & \\
CONST SÃO BERN LTDA & 1 & 29 & & 29 & \\
MUZA CONSTRUTORA & 1 & 96 & & 96 & 192 \\
DAMACENA & 1 & 192 & & & \\
SUMARÉ & 3 & 343 & 256 & 87 & \\
MONTENEGRO & 4 & 142 & & 142 & \\
4 ESTAÇÕES RE. CLUB LTD, & 3 & 160 & & 160 & \\
CRD ENGENHARIA & 2 & 200 & 200 & & \\
CDR/ALVES LIMASPE & 2 & 188 & & 188 & \\
EPOCA ENGENHARIA & 14 & 2.461 & 2.272 & 158 & 31 \\
MAGIS/MRV SPE & 7 & 2.016 & & 1.888 & 128 \\
\hline TOTAL & 39 & 5.995 & 2.896 & 2.748 & 351 \\
\hline
\end{tabular}

Fonte: Dados do Ministério das Cidades disponibilizados em 2015.

(Tabulou-se o intervalo de 2009-2011)

Apesar de algumas empresas produzirem para variadas faixas, observa-se como tendência do mercado a especialização por faixas de renda. Esse dado pode ser decorrente da própria forma de aprovação dos contratos, a rede de agentes envolvidos e as regras do Programa que mudam de acordo com a faixa de renda.

Um caso de especialização é da Época Engenharia que se aproximava do mercado popular de habitação desde o tempo do PAR e, depois de concentrar um grande número de volume de contratações e crescer no mercado, declarou falência, sinalizando para uma instabilidade que será discutida melhor, ao se cuidar das dinâmicas na faixa 1 , no final deste capítulo. 
O segundo caso de especialização das empresas por faixa de renda pode ser reconhecido no consórcio composto pela empresa local MAGIS e pela empresa nacional MRV. Em Fortaleza, a expansão das grandes incorporadoras de capital aberto resultou em parcerias, como foi o caso das duas empresas ora mencionadas. Embora essas parcerias fossem formalizadas juridicamente em cada um dos empreendimentos, por meio da formação de sociedades de propósito específico - SPE, a repetição dessas atividades e a troca de conhecimento fortaleciam os laços entre as empresas parceiras.

A MRV chegou a Fortaleza montando um pequeno escritório e se aliou a uma incorporadora que, em 2007, montou sua estrutura de incorporação com grande recurso e capital proveniente da venda de uma indústria química. Conhecedora do mercado local e com redes de relacionamento já estabelecidas, aproximou-se da empresa mineira MRV e, durante toda a primeira etapa do PMCMV, essa parceria concentrou a maior produção para o segmento econômico da Cidade, o que correspondeu a $68 \%$ das unidades contratadas pelas oito empresas que aprovaram projetos para a segunda faixa de renda junto à CEF.

Sobre os proponentes para o segmento econômico dos anos de 2009 a 2011, identificou-se a atuação de algumas empresas menores prospectando mercados e procurando novas frentes de ação. É o caso da construtora paulista São Bernardo que abriu filial física em Fortaleza e, dentro da perspectiva de abranger e procurar nichos de atuação, contratou um empreendimento junto ao PMCMV.

Há ainda o caso da construtora Muza, que, fundada em 2008, em meio à crise que atingia a economia externa representa a migração de um capital investidor estrangeiro para uma oportunidade em que havia amplos recursos para a construção civil. Os sócios italianos viram essa oportunidade e passaram a atuar com a linha de crédito Imóvel na planta, destinada à construção de empreendimentos imobiliários à faixa de renda 2 do PMCMV, com financiamento da CEF.

Observa-se ainda a parceria entre empresas locais, como é o caso da construtora CRD Engenharia e a construtora e incorporadora Alves Lima. Um dos participantes da CDR é membro ativo do Sinduscon-Ce e integra os conselhos municipais de habitação popular e o Conselho das Cidades do Estado do Ceará, entre outras entidades e órgãos consultivos ligados à habitação. 
Foi possível identificar uma mudança na dinâmica do PMCMV no lançamento de sua segunda etapa ao se tratar do mercado para o segmento econômico em Fortaleza. Verifica-se uma reaproximação das grandes empresas que tinham seu nicho de atuação na alta renda, produzindo alguns empreendimentos para faixas mais populares por meio do PMCMV. Desta feita agindo tanto em parcerias por meio de sociedades de propósito específico quanto por intermédio de sua empresa. São exemplos os casos da Colmeia e Bspar, assim como da parceria entre a empresa local Diagonal e a Rossi Engenharia.

Na tabela seguinte, é possível divisar as empresas e os empreendimentos desenvolvidos na Il etapa do PMCMV no município de Fortaleza.

Tabela 07: Empreendimentos contratados junto a Fortaleza na etapa II 2012-2015

\begin{tabular}{|c|c|c|c|c|c|}
\hline EMPRESA & N. EMP & $\begin{array}{c}\text { TOTAL DE } \\
\text { UHS }\end{array}$ & FAIXA 1 & FAIXA 2 & FAIXA 3 \\
\hline BSPAR & 2 & 298 & & 191 & 107 \\
\hline CARPIL & 1 & 1.992 & 1.992 & & \\
\hline CONCRETO CONST. & 1 & 144 & & 144 & \\
\hline COLMEIA & 1 & 100 & & 100 & \\
\hline ENGEPLAN & 2 & 576 & 576 & & \\
\hline HABITUAL & 1 & 32 & & 32 & \\
\hline JBL CONST. & 7 & 198 & & 174 & 24 \\
\hline MONTENEGRO & 5 & 367 & & 203 & 164 \\
\hline PASSOS & 1 & 210 & & & 210 \\
\hline SUMARÉ & 2 & 272 & 272 & & \\
\hline WEC & 1 & 40 & & 40 & \\
\hline CRD ENG. & 1 & 64 & & & 64 \\
\hline DIAGONAL & 1 & 240 & & 240 & \\
\hline DIRECIONAL & 3 & 10.960 & 10.960 & & \\
\hline ECB BEZERRA & 4 & 768 & 768 & & \\
\hline ÉPOCA ENGENHARIA & 1 & 36 & & 36 & \\
\hline FUJITA & 10 & 7.296 & 7.296 & & \\
\hline ABELARDO ROCHA & 1 & 36 & & 36 & \\
\hline JSC ENG. & 4 & 243 & & 142 & 101 \\
\hline M MOACIR MARINHO & 1 & 24 & & 24 & \\
\hline MARAPONGA II & 1 & 86 & & 86 & \\
\hline MRV ENG. & 4 & 1.070 & & 270 & 800 \\
\hline MUZA CONST. & 1 & 60 & & 60 & \\
\hline ROSSI E DIAGONAL & 1 & 100 & & 100 & \\
\hline ROSSI INCORP. & 1 & 240 & & 240 & \\
\hline VIVENDA DOS GIRASSOIS & 1 & 240 & & & 240 \\
\hline NÃO IDENTIFICADO & 5 & 1.077 & 17 & 550 & 510 \\
\hline TOTAL & 64 & 26.769 & 21.881 & 2.668 & 2.220 \\
\hline
\end{tabular}

Fonte: Dados do Ministério das Cidades, intervalo 2011 - 2015. Elaboração própria. 
Numericamente, há uma ampliação das unidades produzidas para as faixas de maiores rendas, principalmente no que diz respeito ao incremento na faixa 3 , que, em etapas anteriores, não chegava a representar ínfimos $4 \%$ de toda a produção para o Município. Agora com 2.220 UHS contratadas, a faixa 3 parece ganhar nova dinâmica em Fortaleza.

Outra grande mudança é a concentração do número de unidades lançadas por uma mesma construtora na faixa 1, a produção de $68 \%$ das unidades contratadas, pois, exatamente 18.256 unidades habitacionais se concentram sob responsabilidade da Fujita, grande construtora local, juntamente com a Direcional, a maior empresa atuante junto ao PMCMV dentro de todo o Território Nacional.

Passa-se agora a descrever sobre as dinâmicas na faixa 1, suas localizações e arranjos específicos no subitem abaixo.

\subsubsection{Dinâmicas de localização para o mercado de zero a três salários-mínimos}

Na Faixa 1 do PMCMV, que contempla os empreendimentos destinados às famílias com renda de zero a três salários-mínimos, não há a necessidade de comercialização das unidades e a escolha dos beneficiários inexiste. Como foi mencionado, a concepção de um "mercado" propriamente dito nesta faixa do Programa, altera-se, uma vez que o procedimento é estabelecido por meio do Estado que define uma demanda e realiza a inscrição dos beneficiários. A política, entretanto, ainda que definida por intermédio do Estado, depende da participação e dos interesses das empresas construtoras.

Embora a produção habitacional para a Faixa 1 seja predominante no Município de Fortaleza, aspecto positivo da realidade local, ela se tornou, sob condições de produção específicas, um rentável negócio do setor imobiliário. Com suporte em Abramo (2007), procura-se refletir sobre esse ponto. Uma vez que o espaço urbano é gerido pelo Governo, diz o autor, o incentivo a um comportamento de "procura de renda" por partes dos agentes urbanos pode existir.

Percebe-se, por exemplo, que os empresários urbanos podem tentar interferir em leis e em normas urbanísticas, incentivando o Poder Público a interferir nas regras do jogo. A pressão imposta pelo setor que lucra com a atividade imobiliária tem como 
objetivo criar possibilidades de localidades e provocar mudanças nas utilizações do solo, possibilitando aos futuros empreendimentos e aos proprietários da terra uma mais-valia fundiária.

De tal sorte, as negociações e as pressões junto ao Estado se configuram como estratégias de inovações espaciais e, muitas vezes, os empresários participam ativamente das concepções de inovações urbanas.

Entendendo as pressões do setor imobiliário às melhores condições para rentabilizar a faixa 1 como um negócio mais lucrativo, suas ações se dividiram em duas principais frentes: a primeira se refere a conquistar contrapartidas financeiras com a ampliação dos tetos dos valores das unidades; a segunda consiste no rebaixamento das exigências relativas aos serviços urbanos necessários, buscando opções possíveis junto ao Governo local, uma vez que, ante a legislação do PMCMV, elas passam a ser cada vez mais restritivas, conforme endossam Pequeno e Farias (2011) a seguir.

Diante de um cenário de aumento dos preços de terrenos em bairros dotados de infraestrutura, ocorre uma pressão do setor da construção civil para rebaixamento das exigências relativas aos serviços urbanos necessários para a aprovação de terrenos destinados a faixa de 0 a 3 salários mínimos. Esta pressão teve como alvo tanto os bairros situados nas zonas de requalificação urbana definidas pelo Plano Diretor de Fortaleza, como nos municípios periféricos da RMF. (P. 08).

Por meio do histórico das negociações e das falas de vários setores, percebeuse que o entendimento das exigências sobre a localização parecia se resumir em um obstáculo ao andamento do PMCMV na RMF, e não uma opção por garantir a inserção urbana dos empreendimentos de baixa renda.

Os baixos rendimentos provindos do PMCMV, segundo os setores imobiliários, além das queixas expostas em seus discursos sobre a falta de apoio municipal e das graves deficiências de infraestrutura da RMF que exibem terrenos de maior dimensão e com preços compatíveis apenas em regiões não atendidas pela rede de esgoto, tornou-se imperativa a formulação de solução e rebaixamento das exigências sobre esses terrenos.

Notou-se que grande parte dos condomínios para faixa 1 lançados na primeira etapa do PMCMV não conseguiram suprir todas as requisições de infraestrutura urbana que os terrenos deveriam expressar. Como artifício e tentativa de viabilizar 
essa produção, a construtora se responsabilizava pelos gastos adicionais de instalação de rede elétrica, construção de um sistema de esgotamento sanitário temporário ou o que mais a localização devesse exibir, contrariando seus interesses lucrativos.

Como alternativa para a falta de esgotamento sanitário na produção do PMCMV foi permitida a contratação de empreendimentos em terrenos com uma solução temporária, desde que, na matriz de responsabilidades, o Governo do Estado se comprometesse, em um horizonte de cinco anos, depois estendido para dez anos, em implementar a conclusão definitiva de saneamento.

Essa iniciativa foi mostrada pelo Sinduscon-CE, que discutiu propostas com a Secretaria das Cidades e a Companhia de Água e Esgoto do Ceará (CAGECE) a fim de que viabilizassem o funcionamento de estações de esgoto em áreas de interesse social e moradia popular. Além disso, foi encaminhada também sugestão para que a CAGECE se comprometesse a construir nos terrenos dos empreendimentos do PMCMV, em um prazo menor do que o convencional, a rede pública de coleta e tratamento de esgoto sanitário. A proposta foi respaldada e aprovada pelo Conselho Estadual do Meio Ambiente (COEMA) que flexibilizaria a prerrogativa do sistema de esgotamento para a escolha de terrenos, e, dessa forma, se permitiria a garantia de que os recursos federais pudessem ser aproveitados junto ao Estado do Ceará e na $\mathrm{RMF}^{50}$.

Essa flexibilização contraria a fala inicial do superintendente regional da CEF, que, em entrevista, explica sobre a dificuldade de implementação do PMCMV em face da realidade da carência de infraestrutura na RMF, apontando o esgotamento sanitário como o maior problema.

Alguns dos terrenos localizados no interior do Estado e na periferia da Capital não dispõem de rede de esgoto, com coleta, tratamento e destinação final dos dejetos, aspectos obrigatórios no PMCMV. Se o terreno não tem saneamento a Caixa não aprova, portanto, o investimento é inviabilizado ${ }^{51}$.

O que se percebeu, entretanto, nesta pesquisa, foi que, mesmo com o rebaixamento das exigências quanto ao esgotamento sanitário, principal entrave

\footnotetext{
50 Consultar o anúncio das decisões no site da Secretaria do Meio Ambiente: http://www.semace.ce.gov.br/2010/04/reuniao-discute-ajustes-para-o-minha-casa-minha-vida/

${ }^{51}$ Entrevista ao jornal O Estado durante a primeira etapa do Programa.
} 
reunido pelo setor imobiliário, persistiram as dificuldades em alavancar a produção do PMCMV na RMF.

Empresários e construtores explicam que o valor máximo de financiamento de uma unidade do PMCMV é de $\mathrm{R} \$ 41.500$ reais incluindo nesse valor o preço do terreno, da infraestrutura, da execução da obra e do lucro do empreendedor. O acréscimo dos valores dos tetos das unidades foi atualizado em diferentes momentos, e os reajustes revelam como o Programa incorpora a elevação da moradia diante a especulação imobiliária, com um ajuste de $53 \%$ de seus valores.

Gráfico 11: Evolução dos valores máximos de aquisição para o recurso FAR na RMF

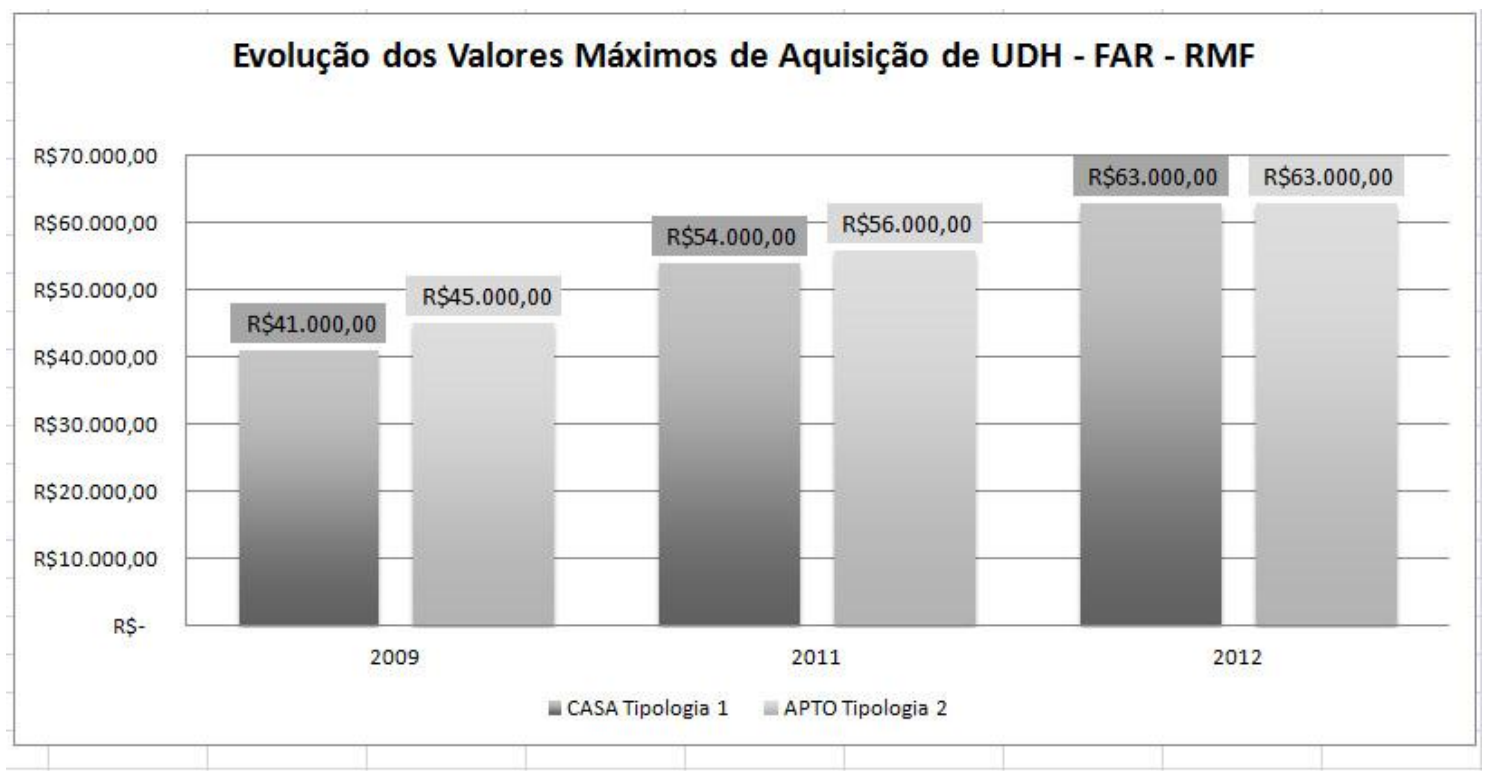

Fonte: Execução de gráfico pelos dados dos dispositivos legais do Ministério das Cidades, em 15/07/2009. 28/09/2011 e 09/11/2012.

O acréscimo do preço de fossas e da infraestrutura necessária foi usado como motivo para o encarecimento das unidades, o que muitas vezes pautou o discurso da ampliação dos valores dos tetos de produção e a necessidade das contrapartidas do Estado.

Segundo levantamentos coletados, houve por parte do Governo do Estado aporte de R\$ 200 milhões em sistema de contrapartidas por meio de recursos do PAC para viabilizar o PMCMV II. De acordo com o próprio presidente do Sinduscon-CE, o Governo estadual permitiu assegurar o financiamento de $\mathrm{R} \$ 2,5$ bilhões do BNDES para 
implementar o Programa, viabilizando a contratação de moradias destinadas à população de 0 a 3 salários-mínimos ${ }^{52}$.

Essa permissão reforça a ideia de que, ante um mercado imobiliário em que as empresas têm dificuldades de atuação, a participação do Estado é fundamental. Essa percepção foi pautada no capítulo, ao indicar as estratégias de atuação direta do Estado na produção habitacional. Historicamente, aconteceu na produção em que o mercado não garantia sua solvabilidade.

Sob as razões públicas de habitação - a produção estatal - entende-se o Estado como o principal agente da produção, cumprindo o papel de incorporador, articulador e definidor das principais decisões e ações para a produção da moradia.

O caso da RMF se mostra, entretanto, diferente. Aqui a participação do Estado é realmente orientada para efetivação de uma política balizada na atuação das empresas construtoras. Ainda que elas mostrem dificuldades e barreiras para cumprir esse papel, a razão do Estado passa a ser regular e fornecer meios necessários para a expansão do setor imobiliário.

Na realidade estudada, o movimento das ações do Estado parece fortalecer a inclusão de novas áreas na dinâmica imobiliária, sem alterar as condições de infraestrutura da Metrópole. O rebaixamento das condições urbanísticas para aquisição de terrenos no PMCMV assegura ganhos do setor imobiliário e a elevação do preço da terra, uma vez que se viabiliza estoques de terrenos em áreas precárias antes não passíveis de construir habitações.

Os altos preços dos terrenos decorrentes do aquecimento da dinâmica imobiliária e de sua elevada procura são constantemente postos como justificativa para a periferização das unidades produzidas pelo PMCMV. Observou-se, contudo, que a busca por novas áreas e estoques de terrenos ainda não explorados constitui ganhos imobiliários e estratégias de recomposição de ganhos para alguns empresários urbanos. Uma vez que o mercado consegue ser ativado em terrenos em que o custo de sua aquisição tem de ser menor em um horizonte de frentes de valorizações imobiliárias, a habitação de interesse social tenderá a ser buscada em terrenos mais

\footnotetext{
52 O Governo do Estado, em parceria com os municípios, dispõe de contrapartidas e recursos na tentativa de viabilizar e efetivar a produção com o recursos federais. Fonte: http://diariodonordeste.verdesmares.com.br/cadernos/negocios/governo-vai-reajustar-limite-do-minha-casa1.1124383
} 
baratos, mais distantes, criando localizações próprias para os excluídos do "mercado" ao serem inclusos na lista de beneficiários. Esse segmento da população tem sua determinação de localização alheia às escolhas.

Foi possível ainda observar que, para as faixas de rendimentos mais baixos, a produção de suas unidades não constitui elemento de valorização de localizações ou, se constitui, sim, como um meio de externalidades, no sentido de atrair interesse imobiliário de outras faixas de renda superiores.

Para a faixa 1, são designados os estoques de terrenos mais precários - aqueles que não podem ser inseridos nas dinâmicas do mercado imobiliário onde formalmente acontece a comercialização das habitações.

Pode-se asseverar com esta pesquisa que o sonho da casa própria para a faixa 1 constitui realidade distante e precária, em um processo que deriva de uma racionalidade espoliativa em que o revés do fortalecimento da atuação do mercado para os segmentos mais baixos de renda é justamente a inserção da lógica imobiliária para aqueles que mais padecem com esse tipo de racionalidade.

A espiral do mercado imobiliário reconfigura os preços e as dinâmicas na RMF, como aparece na escrita de jornais:

E assim, em meio a sonhos, nasce um problema que é inerente à forte demanda que se anuncia: terrenos periféricos dotados de infraestrutura - que em muitos casos seriam ideais para abrigar as moradias do "Minha Casa Minha Vida" para as famílias de zero a três salários mínimos - estão sendo negociados para receber empreendimentos de maior valor ${ }^{53}$.

Esse processo parece ser entendido como consequência natural da forte demanda ensejada pelo incentivo à produção imobiliária e à indústria da construção civil, com o lançamento do PMCMV, e exime o próprio mercado da lógica de reprodução desses valores. Lançar os territórios tradicionalmente desiguais das metrópoles brasileiras e a política habitacional ao funcionamento do mercado como principal mecanismo de coordenação coletiva do uso do solo urbano é dar lastro para uma política habitacional de negócios imobiliários em que a segregação espacial e a contínua alavancagem dos preços dos terrenos avançam, enquanto o Estado, por sua

\footnotetext{
${ }^{53}$ Depoimento do presidente do Sindicato das Empresas de Compra, Venda, Locação, e Administração de Imóveis Residenciais e Comerciais, SECOVI, ao jornal O Povo durante a etapa I do PMCMV, 2010.
} 
vez, garante novos limites estendidos com subsídios e valores para reapropriações financeiras desses ganhos.

Como se pode perceber nos levantamentos coletados, o padrão de distribuição das unidades do PMCMV para a Faixa 1 tende à evidente periferização e ao adensamento das áreas demarcadas como espaços onde grandes conjuntos habitacionais e ocupações irregulares já ocorriam, avançando em direção a alguns territórios e municípios ainda mais distanciados, e concentrando sua grande produção nos municípios já conurbados - Fortaleza, Maracanaú e Caucaia.

A perpetuação da construção de conjuntos residenciais em áreas de baixa infraestrutura e distantes de acessos a serviços é sensível pela escolha das localizações, que mais uma vez voltam aos grandes modelos monofuncionais distanciados da infraestrutura da Cidade. Pode ser expresso como novo o fato de que essa produção agora é feita associada a uma lógica de negócio onde o lucro passa pela discussão dos tetos das unidades e interfere na produção, ancorando a lógica da política habitacional ao discurso de aquecimento da cadeia produtiva da construção civil e geração de empregos.

Sendo os tetos os valores máximos que limitam os preços finais dos imóveis, faz parte do planejamento do lucro da empresa o ato de buscar a maximização dos ganhos pela redução do custo da construção e da procura por localizações de baixo preço. Se não como estratégia de lucros pela incorporação da diferença do preço da valorização da terra, mas, pela escolha deliberada de terrenos de baixos valores e pela ativação de estoques mais e mais distantes. Com a produção simultânea de empreendimentos para os diferentes segmentos, a faixa 1 no PMCMV parece ser impelida para os terrenos mais baratos da região metropolitana.

Sobre a localização dos estoques produzidos junto a faixa 1, é clara a interferência da delimitação espacial imposta na fase inicial do PMCMV, que restringia os contratos até 500 unidades habitacionais, ainda que a legislação não evitasse a superposição desses conjuntos. Esse fator limitante resulta de uma produção mais pulverizada, procurando se instalar em resíduos do tecido urbano.

Durante a primeira etapa do PMCMV, apesar das limitações, verifica-se a opção por terrenos distanciados e menos valorizados para a justaposição dos condomínios. A 
demanda parecia procurar ser atendida por pequenos projetos concretizados na forma de condomínio de até 250 UHS, como previsto nos limites impostos pela legislação.

Esses conjuntos residenciais expressam como característica uma tipologia habitacional multifamiliar de até dois pavimentos, uma solução horizontalizada e fechada entre muros, estabelecendo-se como condomínios. Essa tipologia persistia similar ao projeto que as empresas locais já aprovavam e construíam junto ao PAR, que se destinava às famílias com renda entre 3 a 6 salários-mínimos.

Ainda que a adoção desse tipo habitacional trouxesse problemas para a manutenção e a regulação dos espaços, quando implicavam gastos extras com áreas comuns com funcionários e iluminação, foi esse o projeto repercutido e utilizado pela maioria dos empreendimentos aprovados na primeira etapa do PMCMV; ou seja, foi adotado praticamente como projeto único, desenvolvido pelo Sinduscon-CE com apoio e análise da CEF local.

Como já expresso, a grande parte da dinâmica nas faixas de 0 a 3 saláriosmínimos se concentrou nos municípios limítrofes a Fortaleza, ou nas franjas do espaço urbano da própria Cidade. Durante a primeira etapa, Caucaia foi a grande contratante da produção para a faixa 1, que, em pequenos condomínios limitados ao máximo de 250UHs, concentrou 5368 unidades; seguiu-se Fortaleza, com 2.896; e, na sequência, Maracanaú com 1.600 unidades. A tabela, com dados disponibilizados pelo Ministério das Cidades revela com maior precisão essa realidade.

Tabela 08: Empreendimentos contratados junto a Caucaia e Maracanaú na etapa I 2009-2011

CAUCAIA

\begin{tabular}{|c|c|c|c|c|c|}
\hline EMPRESA & N. EMP & $\begin{array}{c}\text { TOTAL DE } \\
\text { UHS }\end{array}$ & FAIXA 1 & FAIXA 2 & FAIXA 3 \\
\hline INTERPAR & 8 & 2.656 & 2.656 & & \\
EPOCA & 4 & 880 & 880 & & \\
MONTENEGRO & 4 & 672 & 672 & & \\
GUTTA & 2 & 480 & 480 & & \\
AZEV. CASTRO & 1 & 248 & 248 & & \\
MEU LAR EMP IMO & 1 & 432 & 432 & & \\
CREDMOBILE & 1 & 24 & & 24 & $\mathbf{0}$ \\
\hline TOTAL & $\mathbf{2 1}$ & $\mathbf{5 . 3 9 2}$ & $\mathbf{5 . 3 6 8}$ & $\mathbf{2 4}$ & $\mathbf{0}$
\end{tabular}


MARACANAÚ

\begin{tabular}{|c|c|c|c|c|c|}
\hline EMPRESA & N. EMP & $\begin{array}{c}\text { TOTAL DE } \\
\text { UHS }\end{array}$ & FAIXA 1 & FAIXA 2 & FAIXA 3 \\
\hline INTERPAR & 6 & 1.496 & 1.496 \\
CORRETA ENGENHARIA & 1 & 104 & 104 & & \\
PARTIFIB PROJETOS IMO & 1 & 256 & & 256 &
\end{tabular}

TOTAL $8{ }^{\prime} 1.8566^{\prime} 1.600$ 256 0

Fonte: Dados do MCid disponibilizados em 2015, tabulados no intervalo de 2009- 2011.

Com amparo nos indicativos expressos, percebeu-se, inicialmente, que há grande diversidade de perfis das empresas atuantes no PMCMV. Reportando-se ao mercado que se expandiu para os municípios vizinhos, Caucaia e Maracanaú, pode-se fazer uma leitura de que todas as empresas que contrataram e aprovaram projetos nesse período são organizações locais de capital fechado, com exceção da Construtora Azevedo de Castro que tem origem em outro estado do Nordeste, Pernambuco (Recife), mas essa origem ainda a caracteriza como uma empresa de atuação local.

A única exceção a essa realidade é a Empresa Partifib Incorporações que, advinda de São Paulo, contrata o único empreendimento para o mercado de 3 a 6 salários-mínimos em Maracanaú, assumindo atitude distinta das demais empresas locais durante todos os anos do PMCMV nesse Município.

Foi possível identificar que, mesmo exibindo essas qualidades em comum origem da empresa e tipo de seu capital - o espectro dos contratantes junto à faixa 1 do PMCMV denota diferenças. A estrutura dessas empresas é diversa, indicando grupos como o Meu Lar Empreendimentos Imobiliários que, apesar de ser uma agência de corretores e agenciadores de imóveis, contrata empreendimentos para a faixa 1. A empresa se descreve como "empresa que desenvolve e executa projetos de engenharia no mercado imobiliário", situando-se favorável ao estabelecimento de parcerias e aberturas de possibilidades para novos mercados. O grifo se dá porque, justamente, se alega que o setor da faixa 1 só denota interesse para as empresas da construção civil, pois, via de regra, não existe a comercialização das unidades no mercado. 
Percebe-se, ainda, que empresas de destaque na produção habitacional pelo PAR, construindo mais de 1.000 unidades em pelo menos seis empreendimentos -, Época Engenharia, CRD, Engeplan e Montenegro ${ }^{54}$, somadas à Construtora Sumaré, à ECB Engenharia Comércio Bezerra, à Fujita Engenharia -, correspondem ao grupo de construtoras que atuaram tanto no PAR como no PMCMV.

Para a realidade dos municípios de Caucaia e Maracanaú, ressalta-se a atuação das empresas Montenegro e Engeplan, concentrando quatro contratações cada uma. A Engeplan tem origem como firma que atuava junto ao setor público, mas, também, focava seus esforços para o atendimento de clientes privados. Em 2000, ampliou seu foco de atuação e, segundo o próprio site de perfil empresarial, iniciou parcerias com a CEF na construção de edifícios residenciais e condomínios fechados, sendo uma das pioneiras nas entregas de empreendimentos contratados pelo PAR, tendo uma atuação nos mercados do Norte e Nordeste, sendo o Ceará e o Maranhão os estados de maior ação.

A empresa Montenegro possui mais de 30 anos no ramo da construção civil no mercado cearense e incorpora a sua razão social à própria natureza descrita nos programas de que participa. A exemplo da Engeplan, faz referência a seu expertise em inovações tecnológicas e participação no programa de qualidade da construção junto ao Programa Brasileiro de Qualidade e Produtividade, no Habitat - PBQP-H. Essas duas empresas, apesar de estarem fortemente ligadas ao setor da construção civil e à atividade técnica da produção, constam também com os setores de comercialização de imóveis e vendas de unidades, mostrando mais uma vez como nesse setor estão imbricados as esferas da construção civil e do setor imobiliário.

É visível a concentração de empreendimentos na responsabilidade da empresa Interpar, que concentra 4.152 unidades contratadas sob a sua responsabilidade. Essa concentração diz respeito a duas realidades: uma espacial, quando uma mesma produz, em etapas diferentes, vários condomínios justapostos; e a outra, econômica e fundiária, dado que uma só empresa controla boa parte dos empreendimentos nesses dois municípios.

\footnotetext{
${ }^{54}$ Fonte dos dados: Pesquisa de Pequeno e Sarah (2014) sobre os arranjos institucionais do PMCMV.
} 
Sobre a Interpar, esta abriu um braço de atuação em 2005, por empresários atuantes há mais de 30 anos no ramo da construção civil. Anteriormente, focava em projetos de alto padrão, produzindo para o mercado regional, atuando no Ceará e demais estados vizinhos. Enquanto anunciava sua entrada para produção de casas e apartamentos residenciais destinados a populações de baixa renda junto ao PMCMV, já após o lançamento oficial do Programa em 2009, nessa época a empresa tinha em andamento sete empreendimentos de incorporação imobiliária voltados para a alta renda em Fortaleza, confirmando atuação anterior nesse mercado. Em 2012, declarou falência com inúmeros processos associados ao nome da empresa, conflitos trabalhistas e terceirizações da construção civil, conforme apontaram os noticiários.

A dificuldade em estabelecer contatos com empresas que fecharam sua produção para o PMCMV ou encerraram atuação depois de atuar no Programa foi um ponto sensível desta pesquisa. Algumas questões ainda persistem em relação ao tema, como as empresas que mais contrataram unidades na primeira etapa do PMCMV desfizeram parcerias, alegando desistências (no caso das maiores produtoras para a faixa 2) ou declararam falência (no caso das maiores produtoras para a faixa 1).

Em termos gerais, as explicações dadas pelas empresas Época e Interpar ambas com grande representação na produção de unidades junto ao PMCMV, a primeira advinda da experiência do PAR e a segunda a maior contratante de empreendimentos da etapa I do Programa - advêm da dificuldade de lidar com um formato de canteiro que exige extremo controle com os valores reduzidos dos tetos, implicando que qualquer alteração no planejamento significa uma perda do orçamento. A necessidade de racionalização dos métodos de construção para repetir em diversos canteiros e executar com a mesma rapidez grandes empreendimentos foi um desafio e barreira para algumas empresas locais. Somando-se a essas considerações, há os relatos dos próprios construtores que acusam as demoras nos repasses dos financiamentos e a inflação nos valores dos insumos e materiais de construção como razões para desarticulação, desistência e, inclusive, falência de algumas empresas envolvidas com grandes empreendimentos na faixa $1^{55}$.

\footnotetext{
55 Notícia acessada em março de 2014, no jornal O Povo. Os cortes e atrasos nos repasses afetam principalmente as menores construtoras, segundo o presidente do Sinduscon, que em notícia reclama do atrasos dos repasses e bloqueios de investimento pelo governo Federal. "Habitações populares do MCMV2, no Ceará são
} 
As relações a respeito das contratações nesses municípios, na segunda etapa do PMCMV, exprimem novos dados às dinâmicas para as localizações e as contratações junto ao Programa, como é possível se verificar nas tabelas abaixo.

Tabela 09: Emp. contratados junto à Caucaia e Maracanaú na etapa II 2012-2015

\section{CAUCAIA}

\begin{tabular}{|c|c|c|c|c|c|}
\hline EMPRESA & N. EMP & $\begin{array}{c}\text { TOTAL DE } \\
\text { UHS }\end{array}$ & FAIXA 1 & FAIXA 2 & FAIXA 3 \\
\hline ASSOCI CRUZEIRO & 3 & 125 & 125 & & \\
CREDMOBILE & 3 & 88 & & 88 & \\
FETRAECE & 1 & 32 & 32 & 384 & 32 \\
FUJITA & 3 & 416 & & & \\
IMOBILIARIA ABE & 1 & 288 & 288 & & \\
MEU LAR EMP IMO & 2 & 352 & 352 & & $\mathbf{3 2}$ \\
NÃO IDENTIFICADO & 2 & 463 & 391 & $\mathbf{7 2}$ & \\
\hline TOTAL & $\mathbf{1 5}$ & $\mathbf{1 . 7 6 4}$ & $\mathbf{1 . 1 8 8}$ & $\mathbf{5 4 4}$ &
\end{tabular}

MARACANAÚ

\begin{tabular}{|c|c|c|c|c|c|}
\hline EMPRESA & N. EMP & $\begin{array}{c}\text { TOTAL DE } \\
\text { UHS }\end{array}$ & FAIXA 1 & FAIXA 2 & FAIXA 3 \\
\hline DIRECIONAL & 1 & 2.096 & 2.096 & & \\
SUMARÉ & 1 & 112 & 112 & & \\
MONTENEGRO & 1 & 288 & 288 & & \\
INSTITUTO PAJU & 1 & 49 & 49 & & $\mathbf{0}$ \\
\hline TOTAL & $\mathbf{4}$ & $\mathbf{2 . 5 4 5}$ & $\mathbf{2 . 5 4 5}$ & $\mathbf{0}$ &
\end{tabular}

Fonte: Dados do Ministério das Cidades disponibilizados em 2015.

Tabulados o intervalo de 2009 a 2011.

Em Caucaia, a produção para a faixa 1 aponta alguma redução, enquanto o segmento da faixas 2 e 3 mostra avanço em direção aos terrenos além dos limites de Fortaleza. Destaca-se o fato de que grande parte das unidades contratadas em Caucaia é associada às comunidades indígenas. As contratações pela Associação Cruzeiro e pelo Residencial Jandaiguaba têm seu contrato alavancado por movimentos sociais organizados. Esses dois empreendimentos somam um total de 516 unidades que correspondem quase metade das contratações junto à faixa 1 em Caucaia. Restam 602 
unidades contratadas pela iniciativa das empresas construtoras, chegando muito próximo das 544 unidades lançadas junto ao segmento econômico que corresponde às faixas 2 e 3 do PMCMV.

Com essa informação, pode-se afirmar o avanço do mercado em uma expansão para o oeste de Fortaleza. A empresa Fujita é exemplar nessa empreitada e produz 384 em três empreendimentos.

Em Caucaia, persistem as agências imobiliárias que se articulam e lançam empreendimentos para a faixa 1. Cita-se a Meu Lar Empreendimentos Imobiliários, que havia realizado uma contratação dos anos de 2009 a 2011, assim como a Imobiliária Abelardo, que, por meio de pequenas parcerias, se constituem como agentes do PMCMV na região.

Em Maracanaú, também são notados empreendimentos associados à modalidade do PMCMV- Entidades, em que o implemento é associado a um grupo de beneficiários organizados. O Município não tem nenhum empreendimento voltado à faixa 2 e sua produção é condensada praticamente em uma iniciativa, na Direcional Engenharia. O empreendimento sob o nome de "Orgulho do Ceará" foi contratado junto ao Banco do Brasil, fazendo parte da parceria Governo do Estado - Direcional BB. Esses foram, sem dúvida, os maiores articuladores da produção habitacional na segunda etapa do PMCMV na RMF.

É notório, ainda, o fato de que a atuação das pequenas empresas se torna mais rarefeita, principalmente nos municípios onde, durante toda a primeira etapa, concentram pequenos condomínios justapostos aos modelos dos condomínios do PAR. É exemplo dessa atuação a Construtora Montenegro, que desde o programa PAR vinha contratando UHS e focando seu nicho no mercado de habitações populares financiadas pela CEF. Essa empresa passa agora a ter uma atividade diminuta em Maracanaú, tendo somente um contrato na faixa 1, com 288 unidades durante a segunda etapa. 
Gráfico 10: Produção da empresa e construtora Montenegro

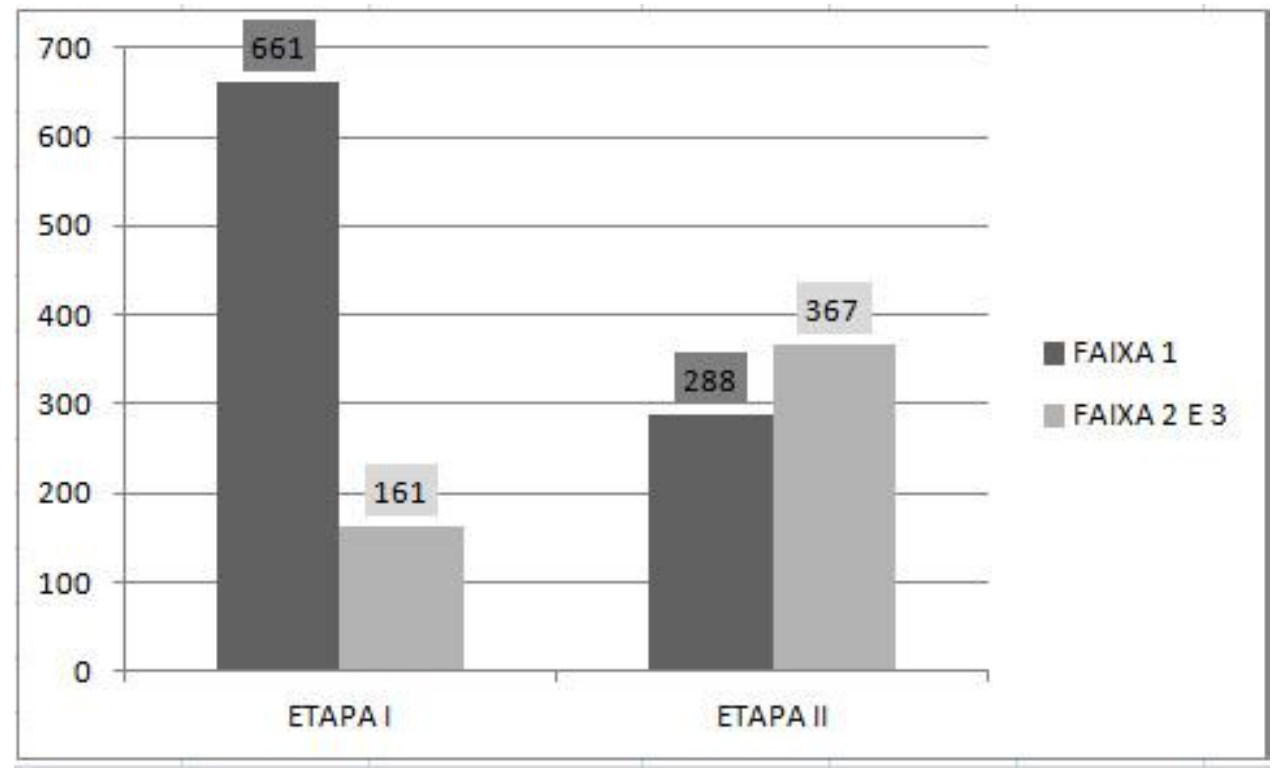

Fonte: Dados do Ministério das Cidades

Nota-se que a atuação migra de faixa, entrando no mercado econômico e produzindo para rendas mais altas. Parece transparecer é o fato de que o nicho de atuação das pequenas empresas locais passa a ser dominado pelas organizações nacionais, tornando-se uma disputa de grandes empresas.

No caso da produção no município em Fortaleza (checar tabela 06) , é possível reconhecer a disputa entre as empresas locais Fujita S.A e Direcional, as duas maiores contratantes de empreendimentos na etapa II do PMCMV. A primeira, advinda do PAR, assume parceria com o Governo do Estado, responsabilizando-se por 5.536UHS justapostas. Hoje, continua a se posicionar para novos contratos, assinando a execução do primeiro PMCMV na modalidade Entidades, com 3.000 ou mais unidades a serem construídas. Já a Direcional expandiu mercados, atuando em 11 estados da Federação. Segundo dados de 2014, a Direcional já contratava cerca de 61.900 unidades e 3,6 bilhões de reais junto ao PMCMV. Com uma produção essencialmente voltada para a faixa 1 , cerca de $80 \%$ do faturamento, a Direcional desponta como uma das maiores empresas que atuam e concentram contratos no PMCMV.

Essa concentração deve ser também entendida na ordem do porte dos empreendimentos - a Direcional assume maiores contratos. Em 2014, segundo as palavras de seu diretor, "temos em construção, neste momento, mais de 50 mil unidades, sendo 40 mil relacionadas ao Minha Casa, Minha Vida. Deste programa, 
entregamos na semana passada 9 mil unidades em uma única obra em Manaus. E, até meados de março, entregaremos quase 10 mil (unidades) em Macapá, Brasília e Rio de Janeiro" ${ }^{256}$. Percebeu-se, aqui, grandes contratos, constituindo-se como a única empresa que executa bairros inteiros em cidades brasileiras.

A chegada da segunda etapa do PMCMV retoma a produção de grandes conjuntos na RMF, ensejando demanda fora do padrão de um mercado de habitação. Os contratos organizam uma demanda imediata, racionalizada na ordem de 5.000 unidades habitacionais que ficam no controle e no encargo de uma só empresa. A produção de verdadeiros bairros é articulada com grandes empresas e com o apoio do Governo e do Banco do Brasil. Tais situações tendem a tornar mais evidente o descompasso da acelerada produção de unidades habitacionais e em relação às dificuldades e limitações para consolidar situações urbanas adequadas. Essas são questões relevantes que marcam o desenvolvimento do PMCMV na RMF.

\subsection{Mudanças sobre a apropriação do espaço e a valorização imobiliária}

Ao final desta análise, alguns pontos importantes emergem. O primeiro diz respeito à realidade e à participação das empresas no desenvolvimento do Programa na RMF. Apesar de dar primazia ao setor privado na execução do Programa, observamse níveis diversos de interesse e, principalmente, a influência dessas empresas em termos de sua atuação e participação no programa habitacional.

Em meio a uma dinâmica própria de um mercado conservador como de Fortaleza, focado em uma produção baseada em capital próprio, um mercado com traços "à moda antiga 57", Rufino (2012) destaca que, na percepção de outras empresas nacionais, esta Metrópole demonstra certo atraso em comparação às relações desenvolvidas em outras regiões, onde o negócio imobiliário já é muito mais evidente e cada vez mais a construção perde espaço para as relações financeiras e de incorporação, respondendo de maneira muito mais centralizada e especializada ante a abertura de mercados que o PMCMV realiza.

\footnotetext{
${ }^{56}$ Noticiário Hoje em dia, Belo Horizonte, em 09/2014.

${ }^{57}$ Em entrevista ao jornal O povo, em outubro de 2015, construtor do setor expressa termo para falar de uma postura resguardada, conservadora, "à moda antiga", em que os empresários locais "só prefere fazer o que dá para aguentar".
} 
Num mercado onde as grandes empresas dependeram de parcerias com o poder e capital de influentes famílias, a política de crédito crescente favoreceu pequenas e médias empresas que orientaram parte de seu esforço para o mercado popular de habitação, contudo, a própria característica concentradora que o PMCMV assume em diversas cidades, incluindo a RMF, demonstra as disputas entre as inserções das grandes empresas de capital aberto em mercados locais e essas ensejam questões muito próprias, como os casos da Rossi, MRV, Rodobens e Direcional Engenharia.

As crescentes demandas do PMCMV em termos de tamanho dos empreendimentos e capacidade da gestão e execução das construtoras apontam para um afunilamento das atividades, concentrando ainda mais a produção. Essa concentração tem duas faces: uma, em termos dos agentes envolvidos, fortalecendo empreiteiras específicas; e a outra, em termos espaciais, uma vez que esses conjuntos são efetivados em uma mesma gleba ou em terrenos contíguos.

A leitura geral das dinâmicas dessas empresas junto ao PMCMV pode ser, muitas vezes, entendida como instabilidade, uma vez que as empresas vislumbram e investem na aquisição do financiamento pela Caixa, apostam na entrada do mercado popular e, dependendo de sua arrecadação, recuam ou partem para selecionar uma faixa de renda específica. Essas idas e vindas e desistências marcam a entrada e saída de agentes e são uma constante no desenrolar do Programa que depende do modelo de negócio das empresas e do interesse destes para garantir sua efetivação. Nesses movimentos, é perceptível o recuo de empresas com grande participação no Programa, o que conduz a se indagar o que está por trás dessas desistências, desmanches e falências. Uma vez que as maiores empresas envolvidas na etapa I do Programa, Interpar, Epoca, Montenegro na virada para a etapa II praticamente recuam dando lugar para grandes empresas construtoras capazes de absorver contratos com mais de 3 mil UHS, a grande Direcional Engenharia e a empresa Fujita, reforçando ainda mais o caráter concentrador que o Programa expressava.

O segundo ponto de relevância é que, apesar de uma contratação aquém das expectativas, o reforço da atividade imobiliária, o aquecimento do setor da construção e a procura por novos terrenos para ativação de um mercado praticamente não 
explorado pelas empresas construtoras na Capital - o setor de média e baixa renda ensejam grandes mudanças. Se não há um redesenho da Metrópole, em termos de ampliação de sua mancha urbana, quando pensado o redesenho dos valores e das migrações de faixas de rendas entre bairros, essa situação se reconfigura.

A valorização imobiliária intensificada nos empreendimentos para as faixas de renda intermediárias se generaliza elevando o preço do terreno, o valor dos estoques e a importância do aluguel da habitação, redefinindo os preços das novas unidades.

O PMCMV acirra as disputas entre as apropriações do espaço e favorece a ampliação da atividade imobiliária, principalmente, nas áreas de maior expansão, nas áreas mais distantes, dando saltos de valorização onde o mercado consegue rentabilizar e assegurar a comercialização para as faixas de rendas médias.

Por fim, é possível perceber que toda essa espiral contribui para o reforço da precariedade habitacional, antes evidenciada, promovendo o adensamento de áreas sem infraestrutura e das demais com baixo valor imobiliário. Essa ampliação imobiliária constitui um meio de valorização daqueles que lucram com a renda da terra e exacerba as diferenciações sociais preexistentes na Metrópole entre o leste e o oeste, tornando complexas novas relações de fragmentação, à medida que a atividade imobiliária avança além dos bairros onde o setor costumava atuar. 


\section{Considerações Finais}

Ao investigar a produção imobiliária junto ao Programa Minha Casa Minha Vida na Região Metropolitana de Fortaleza, a partir do enfoque das escolhas de terrenos, evidenciou-se a ativação de novas regiões, que consolida importante movimento de intensificação dos mercados de terras. Esse processo, emergente de novas estratégias na produção imobiliária impulsionada pelos recursos e apoio de um programa público habitacional, incita uma lógica peculiar de apropriação do espaço, onde se reforça a reprodução do capital em detrimento das necessidades de reprodução social, de planejamento ordenado da cidade, do seu rendimento ou qualquer outro conceito. A análise deste estudo indica que essa racionalidade parece passar pela valorização dos terrenos e pelo avanço do cálculo do lucro dos produtos.

Ainda que as mudanças evidenciadas na Região Metropolitana de Fortaleza tragam algo em particular, essas, em sua totalidade, são pertinentes a um quadro geral da produção do PMCMV. Há muitos gargalos e conflitos que caracterizam a produção do PMCMV no Território Nacional que, aqui, nesta região, também, se demonstram como realidade. É perceptível o fato de que a condição particular da RMF atravessa a mediação dessa estrutura total que se impõe pelo desenho institucional do Programa, pelas negociações e hegemonias políticas, pela regulação do crédito e por tantas outras razões que perpassam a realidade estudada.

Compreende-se que essas mudanças, gestadas no âmbito federal, mesmo em décadas anteriores ao lançamento do PMCMV, com a formatação dos instrumentos jurídicos e securitização de créditos já conquistados por meio de medidas regulatórias e do aumento de recursos destinados ao financiamento habitacional, favoreceram uma intensa transformação no setor da construção civil. A corrida para a abertura de capitais e a ampliação de mercado de terras aconteceram antes de a primeira medida provisória ser lançada em meio a um processo que favoreceu, desde os anos 1990, a ampliação do mercado da construção civil para os estratos mais populares.

A forte coesão entre o Governo e o empresariado da construção civil aparece na fala de importantes agentes que participaram da gestação do PMCMV. Assim, um novo programa habitacional a ser priorizado pelo Governo era montado sob a 
perspectiva do entendimento da atuação do mercado imobiliário, harmonizando os interesses do setor na tentativa de assegurar menores riscos e atratividades para os investidores.

De tal sorte, a provisão habitacional passa pelos negócios imobiliários e pela iniciativa privada, muito mais do que por uma lógica de planejamento urbano e de atendimento social das necessidades habitacionais.

A análise da legislação constatou que a operacionalização do PMCMV não inibe a participação de agentes organizados do movimento social ou prefeitura, contudo, essas iniciativas são lançadas na espiral do mercado, no aumento da valorização e na lógica do negócio, inibindo a atuação desses agentes, e, mais agravado ainda, inibindo conceitos intrínsecos ao da habitação social, como o direito à cidade.

Ainda no pertinente à legislação do PMCMV, observou-se que a sua montagem operou no sentido de eliminar entraves para alcançar um "modelo de negócio". O Programa seleciona um conjunto de experiências de políticas habitacionais, desde o Governo do FHC, àquelas com princípios gerais que favorecessem o modelo da iniciativa privada, além de recobrar os aspectos mais flexíveis e maleáveis contidos no Programa de Arrendamento Residencial para a concretização do Programa Minha Casa Minha Vida.

Esse modelo excluía, definitivamente, a promoção estatal como se conhecia até então. As antigas COHAB's e as cooperativas que atuavam como agentes promotores, concentrando as decisões da produção habitacional na articulação com um agente financeiro, sendo o BNH ou a CEF, somem da cena. Antes, se a empresa era uma prestadora de serviço, ela passava a ganhar mais espaço de decisão. Com o PMCMV, a centralidade não está mais em apenas um agente, pois, são diversos os produtos e as táticas de participação. A massiva produção passa, entretanto, pela contratação e pelas definições das empresas.

O Programa atualizou os arranjos institucionais que agora operam, principalmente, por intermédio do agente financeiro - Caixa Econômica Federal e Banco do Brasil - agente executor e consumidores e prefeitura/Governo estadual estes últimos, só se manifestam, especificamente, na execução dos empreendimentos para a faixa 1. O agente executor, antes apenas um prestador de serviços, agora atua como um agente imobiliário, um incorporador. Assume todas as etapas da promoção 
imobiliária, desde a aquisição do terreno, elaboração do projeto e até a comercialização, com ressalva dos empreendimentos para faixa 1 , que, como se sabe, tem um público-alvo proveniente do cadastro do município, não havendo a necessidade da venda das unidades no mercado propriamente dito.

A recuperação da legislação mostra que o PMCMV funcionou com apenas uma medida provisória, em seus primeiros quatro meses de andamento. A maior parte do aprimoramento da legislação, como consta no próprio sítio do Governo Federal, na internet, ocorreu desde a segunda fase do PMCMV. Foi depois de 2011 que se reajustaram os valores da faixa de renda, ampliaram-se escopos e metas, focalizando, massivamente, na faixa 1 , assim como foi tentada a melhoraria dos requisitos e especificações para o interior das unidades habitacionais.

Se, inicialmente, o PMCMV tinha critérios praticamente vazios em matéria de escolha da localização, com a sua evolução, se pontua alguma clareza e definições quanto à necessidade de equipamentos e serviços públicos. Do ponto de vista legal, o PMCMV define critérios restritivos acerca das qualidades do terreno e de algumas indicações de localização quanto à inserção do empreendimento na malha urbana. Foram delegadas aos contratantes dos empreendimentos a prática e a operacionalização do Programa, ficando, muitas vezes, ao encargo da iniciativa privada encontrar e escolher um terreno passível de iniciar o empreendimento.

É perante essas questões que se suscita como um programa habitacional deste vulto, não se levantam importantes pontos para resolver a habitação no Brasil. Sua ordem e seu desenvolvimento passam muito mais pela ordem econômica e quantitativa, não se esmerando em resolver os entraves da gestão pública e, sim, repassando a regulação da atividade produtiva às empresas privadas.

Sobre a estrutura de provisão da habitação, conforme exposto por Ball (2006), confirma-se que o PMCMV promoveu uma configuração que articula empresas executoras e agente financeiro, constituindo uma centralidade dividida nos papéis desses agentes, dependendo com que produto ou faixa se articula.

O capítulo três desta investigação mostrou as condições preexistentes que iluminaram o caso da produção do PMCMV na RMF. São aspectos importantes para a compreensão dos dados e amarração do panorama em que se configura a articulação dos agentes e as escolhas dos terrenos. Com suporte neles, entende-se que o setor 
imobiliário e da construção civil em Fortaleza possuem uma dinâmica baseada em capital próprio, um mercado com traços "atrasados", uma vez comparados com as relações desenvolvidas em outras regiões, onde o negócio imobiliário já é muito mais evidente e cada vez mais a construção perde espaço para as relações financeiras e de incorporação. Em Fortaleza, o próprio setor da construção civil se confunde com o setor imobiliário. Nos relatos, foi visto que as empresas realizam duplamente as atividades de construção e as de incorporação, sendo esta última especialização um elemento novo na RMF - é relativa aos anos de 2005 em diante. Mais recente ainda é a inserção das grandes empresas nacionais no mercado local, que, como visto, enseja uma série de mudanças e estabelece novas parcerias que apontam para investimentos em padrões e localizações diversas.

Em Fortaleza, tradicionalmente, se constituem empresas de portes diversos, e, é importante ressaltar, na indústria da construção civil, predomina uma estrutura mais vertical, em que a direção e o desenvolvimento das atividades são associados à figura de engenheiros e de cargos técnicos relacionados ao processo construtivo. Essa estrutura foi chave para explicar a maior contratação em números junto à faixa 1 em todas as etapas do PMCMV, visto que essas empresas têm uma estrutura que de certo feito, favorece a concentração de sua atividade na construção civil.

A grande diferença de porte e de concentração de capital sucedia, principalmente, pela possibilidade que algumas empresas tiveram ao se aliar com as oligarquias locais, o que ainda assegurava uma oportunidade tradicional e conversadora de produzir o negócio imobiliário. Esses grandes grupos imobiliários, além de deter o capital para financiar os empreendimentos, concentravam a propriedade da terra.

A condição de concentração de terras em Fortaleza também é outro traço importante a ser referido, uma vez que a terra no desenvolvimento do Programa se mostra como barreira para sua viabilização, mas, também, como frente de valorização.

O mercado de terras em Fortaleza delineou-se articulado ao poder das grandes famílias detentoras do capital local, começando nos anos de 1930, quando foi percebida a capacidade de produzir riquezas da especulação imobiliária e da renda da terra. Era notório o fato de que os empresários locais conduziam e limitavam a Cidade com seu poder de propriedade. Nas décadas seguintes, os loteamentos avançaram em 
várias direções, e os números de novos loteamentos explodiram nos anos de 1950-60. Os capitais excedentes das oligarquias associados à atividade imobiliária já se movimentavam para transpor a mancha urbana, comprando terras e propriedades rurais, redefinindo usos e acumulando estoques de terrenos. Nos anos de 1990-2000, é sinalizado o fato de que, praticamente, todo o território do Município de Fortaleza já estava parcelado e em determinadas mãos.

Essa lógica de parcelamento precoce e de extensão da Cidade desencadeou intensa retenção de terra que, com a alta da atividade imobiliária e o aquecimento dos mercados, teve uma elevação do preço ainda maior. Para a execução dos empreendimentos do PMCMV, o que se viu foi um salto para os limites além da Metrópole ou para bairros que ainda ofereciam grandes lotes remanescentes ou de desocupação de antigos imóveis rurais ou de indústrias.

Percebeu-se, também, a precariedade habitacional e de infraestrutura da Cidade, que, embora tradicionalmente configure uma dicotomia leste-oeste, avança em processos fragmentados de precarização e de falta de urbanização de vários territórios. Em uma estrutura urbana por demais oligopolizada e concentradora de renda, terrenos e serviços, esses processos concedem a Fortaleza um espectro desigual de metrópole. O crescimento da população e a falta de acesso a terrenos consolidaram uma produção bipartida com base na estrutura da terra, o loteamento para os ricos e o loteamento para pobres.

A cidade desigual se afirma com o predomínio de uma grande população empobrecida, produzindo sua casa por meio da autoprodução ou produção "doméstica". Contraditoriamente, o avanço das forças capitalistas no espaço e no mercado de habitação popular reforçou essa produção desigual na Metrópole, adensando terrenos precários e ampliando a retenção de terrenos e frentes de valorização do mercado de terras.

Essa realidade foi mais compreendida no capítulo três quando se percebe que o padrão distribuidor das unidades do PMCMV para a faixa 1 tende à evidente periferização e ao adensamento das áreas demarcadas como espaços onde grandes conjuntos habitacionais e ocupações irregulares já ocorriam, avançando em direção a alguns territórios e municípios ainda mais distanciados, e concentrando sua grande produção nos municípios já conurbados - Fortaleza, Maracanaú e Caucaia. 
Pode ser aposto como novo é o fato de essa produção agora ser associada a um negócio onde o lucro passa pela discussão dos tetos das unidades e interfere na produção, ancorando a lógica da política habitacional ao discurso de aquecimento da cadeia produtiva da construção civil e geração de empregos.

Curiosamente, se, por um lado, o resultado quantitativo das faixas 2 e 3 do PMCMV na RMF não representa grandes números - registrando 10.617 unidades nos municípios de Caucaia, Fortaleza e Maracanaú - de outra parte, a importância do deslocamento dessas faixas de renda para outros bairros da Metrópole significa mudança significativa.

Os casos de Messejana, Passaré, Parangaba, Maraponga, Henrique Jorge, Mondubim e outros bairros no entorno da Cidade marcam um movimento de readensamento de áreas urbanas deixadas pelos contínuos saltos do processo de urbanização. Nessas grandes áreas, foram implementados conjuntos residenciais para o segmento popular do PMCMV e a valorização dessas terras exprime um crescimento sem igual na Metrópole. Alguns desses bairros são citados como recordistas de lançamentos de empreendimentos durante os anos de atuação do PMCMV até o ano de 2015, demonstrando a apropriação seletiva na descrição dos produtos para as faixas 2 e 3.

Se a ampliação relativa aos números de unidades não parece representativa, ressalta-se a importância da redefinição do quadrante da atuação do mercado imobiliário em Fortaleza, que desponta para novas centralidades e se dirige para as periferias e, algumas vezes, é associado à valorização por meio da construção de infraestruturas ou de metrô que avançam para depois dos limites do Município.

Nota-se que esse processo é naturalizado como resultado de intensiva demanda produzida pelo incentivo à produção imobiliária e à indústria da construção civil. Com o lançamento do PMCMV, ele exime o próprio mercado de reprodução desses valores. Lançar os territórios tradicionalmente desiguais das metrópoles brasileiras e a política habitacional ao funcionamento do mercado como principal mecanismo de coordenação coletiva do uso do solo urbano é dar lastro para uma política habitacional de negócios imobiliários em que a segregação espacial e a contínua alavancagem dos preços dos terrenos avançam, enquanto o Estado, por sua 
vez, garante novos limites estendidos com subsídios e valores para reapropriações financeiras desses ganhos.

Nesse processo se evidencia a expansão da produção imobiliária, por si, e sua associação à produção habitacional em uma base de metrópole desigual em que se acirram conflitos e promovem uma produção do espaço que nega a dimensão urbana e social, favorecendo apenas a dimensão da reprodução do capital no espaço. Nesse sentido, a incorporação da política pública pela lógica privada encontra na cidade um potencial de reprodução e os efeitos que ainda precisam ser rastreados, uma vez que a cidade tem esse aspecto caleidoscópico e dinâmico em que as escolhas de localização definem preços que se disseminam para todos os estoques, aluguéis, compras de novos terrenos etc.

Em um panorama onde se discute a ampliação do PMCMV para a terceira etapa, com o investimento de mais 720 milhões que ampliam sua expansão para municípios ainda menores, de menos de 50 mil habitantes, em que as forças de regulação do Estado são também mais diminutas, reforça-se a necessidade de revisão dos arranjos institucionais deste Programa e da aplicação do fundo público destinado à habitação.

Conclui-se, portanto, apoiando-se em Abramo (2007), que esta análise é um alerta para os riscos do retorno do mercado como principal mecanismo de coordenação coletiva do solo urbano. As liberdades do mercado carecem de intervenção e controle público para a garantia de uma cidade mais igualitária em termos de acesso e distribuição da riqueza urbana. Contra o reforço de uma mão inexorável do mercado, se demonstra a necessidade de uma ação pública coordenada, para que não apenas se entregue a cidade ao planejamento do negócio imobiliário, mas, que o avanço dos pluralismos na habitação represente de fato a inserção de variados agentes que alcancem a participação popular, retirando da mão das grandes empreiteiras a real implementação das políticas públicas.

A habitação popular deve, sim, ser inclusa em programas de governos e há de ser prioridade, não em favor da acumulação de capital de setores do empresariado, e, sim, na direção do desenvolvimento social com vistas a equalizar os abismos sociais que se encontram na sociedade brasileira e já cristalizados na dimensão urbana de Fortaleza e de tantas outras metrópoles do Brasil. 


\section{Referências Bibliográficas}

ABRAMO, Pedro. A Regulação urbana e o regime urbano: a estrutura urbana, sua reprodutibilidade e o capital. Porto Alegre: Ensaios FEE, 1995.

.Mercado e ordem urbana: do caos à teoria da localização residencial. Rio de Janeiro: Bertrand Brasil, 2001.

A cidade caleidoscópica: coordenação espacial e convenção urbana. Uma perspectiva heterodoxa para a economia urbana. Rio de Janeiro: Bertrand do Brasil, 2007.

ARAGÃO, Thêmis Amorim. Influência das Políticas Habitacionais na Construção do Espaço Urbano Metropolitano de Fortaleza: história e perspectiva. Dissertação apresentada ao Programa de Pós Graduação em Planejamento Urbano e Regional da Universidade Federal do Rio de Janeiro. 2010.

ARANTES, Pedro F.. Pesquisa sobre o PAR apresenta antecedentes do "Minha Casa, Minha Vida". Revista Pós. São Paulo, v.17, n.28, dez. p.275-280. 2010.

ARAÚJO, Ana Cristina. O Programa minha Casa Minha Vida: antigos e novos dilemas da habitação social e o caso de Marília- SP. Tese de doutorado apresentada ao Programa de PósGraduação da Faculdade de Arquitetura e Urbanismo da Universidade de São Carlos, 2013.

ARRETCHE, Marta. Intervenção do Estado e setor privado: o modelo brasileiro de política habitacional. Espaços e Debates, ano X, n.31, pp. 21-36, (1990).

AZEVEDO, Sérgio de. Vinte e dois anos de Política de Habitação Popular (1964-86): criação, trajetória e extinção do BNH. (1988). Artigo publicado Fundação Getúlio Vargas http://bibliotecadigital.fgv.br/ojs/index.php/rap/article/viewFile/9391/8458

BALL, Michael. Housing analysis: time for a theoretical refocus. Housing studies. London, v. 1, i. 3, pp. 147-165, 1986.

. Housing and social change in Europe and the USA. 1988.

. Market \& Institutions in Real State \& Construction. Oxford: Blackwell Publishing, 2006.

BERNAL, Maria Cleide Carlos. A Metrópole Emergente. A Ação do Capital Imobiliário na Estruturação Urbana de Fortaleza. Fortaleza: Editora UFC, 2004.

BONDUKI, Nabil Georges. Origens da Habitação social no Brasil. 2a Edição. São Paulo: Estação Liberdade, 1999. 344 p.

Do Projeto Moradia ao Programa Minha Casa. Revista: Teoria e Debate, n.82, pp 8-14, 2009.

Política habitacional e inclusão social no Brasil: revisão histórica e novas perspectivas no governo Lula". In: Revista eletrônica de Arquitetura e Urbanismo. São Paulo, n. 
1, p. 70-104, 2008. Disponível em <http://www.usjt.br /arq.urb/ numero_01/artigo_05 _180908.pdf>.

CARDOSO, Adauto Lúcio; ARAGÃO, Thêmis Amorim. Reestruturação do setor imobiliário e o papel do Programa Minha Casa Minha Vida. In: SEMINÁRIO DA RED IBEROAMERICANA DE INVESTIGADORES SOBRE GLOBALIZACIÓN Y TERRITORIO, 12, Belo Horizonte, 2012.

CHESNAIS, François. La Théorie du regime d'accumulation financiarisé: contenu, portée e interrogations. Paris. Mimeo, 2002.

CUNHA, Gabriel Rodrigues. O Programa Minha Cada Minha Vida em São José do Rio Preto/SP: Estado, Mercado, Planejamento Urbano e Habitação. Campinas: Tese de doutorado apresentada ao Programa de Pós-Graduação em Desenvolvimento Econômico da Universidade Estadual de Campinas. Campinas/SP: 2014.

DEÁK, Csaba. Localização e espaço: valor de uso e valor. Capítulo 4 de Renttheoryandthepriceofurbanland/ Spatialorganization in a capitalisteconomy, PhD Thesis, Cambridge University, 1985. Disponível em: http://www.usp.br/fau/docentes/ depprojeto/c_deak/CD/3publ/85r-thry/4loc-spac/Cap4-loc-esp.pdf . Uma interpretação histórica da teoria de renda. Revista de Desenvolvimento Urbano e Regional 2(1):41-57; Sinopses 18:26-39, 1992. Disponível em: http://www. usp.br/fau/docentes/depprojeto/c_deak/CD/3publ/87tr/index.html À busca das categorias da produção do espaço, Capítulo 5. Tese de Livredocência, FAUUSP, 2001.

FERREIRA, João Sette Whitaker. (coord.) Produzir casas ou construir cidades: desafios para um novo Brasil urbano. São Paulo: FUPAM, 2012.

FIX, Mariana de Azevedo Barretto. Financeirização e transformações recentes no circuito imobiliário do Brasil. Tese de Doutorado em Desenvolvimento Econômico da Universidade Estadual de Campinas, São Paulo, 2011.

FIX, Mariana; ARANTES, Pedro Fiori. Como o governo Lula pretende resolver o problema da habitação. Alguns comentários sobre o pacote habitacional Minha Casa, Minha Vida. Correio da Cidadania. Disponível em: <http:// correiocidadania.com.br> Acesso: 8/out/2009.

FUCK JUNIOR, Sérgio C. de França. Expansão urbana e segregação espacial no sudeste do município de Fortaleza. Dissertação de mestrado acadêmico em Geografia da Universidade Estadual do Ceará. Fortaleza: 2002. 
FREITAS, Clarissa Figuereido Sampaio. Ilegalidade e degradação em Fortaleza: os riscos do conflito entre a agenda urbana e ambiental brasileira. Urbe. Revista Brasileira de Gestão Urbana, v. 6, p. 109-125, 2014.

GIL, Antônio Carlos. Como elaborar projetos de pesquisa. 4 a edição. São Paulo: Atlas, 2002.

GONDIM, L. M. de Pontes. Fortaleza 1987: crescimento, opulência e miséria. Fortaleza, 1987.

GOTTDIENER, Mark. A produção social do espaço urbano. $2^{\text {a }}$ edição. São Paulo: Edusp, 1997.

GREGÓRIO, Carolina. Minha Casa Minha Vida 2. Discussão sobre a atratividade dos empreendimentos voltados à faixa de 0 a 3 sm. In: Revista Construção e Mercado - Pini Outubro, 2011.

HARVEY, David. O trabalho, o capital e o conflito de classes em torno do ambiente construído nas sociedades capistalistas avançadas. Espaço e Debate n. 6, jun/set. 1982.

JARAMILLO, Samuel. Produccíon de vivienda y capitalismo dependiente: el caso de Bogotá. Bogotá, Colombia: Editoria Dintel, 1980.

LEFEBVRE, Henri. La production de l'espace. Paris: Anthropos. Tradução preliminar de Jorge H. Oseki (mimeo.), 1986.

LOUREIRO, Maria Rita; MACÁRIO, Vinícius; GUERRA, Pedro. Democracia, arenas decisórias e políticas públicas: o Programa Minha Casa Minha Vida. IPEA, Rio de Janeiro, 2013.

LORENZETTI, Maria Silvia Barros. A questão habitacional no Brasil. Consultoria Legislativa da Câmara dos Deputados. Brasília. 2001.

MAY, Tim. Pesquisa social: questões, métodos e processos. Porto Alegre: Artmed, 2004.

MARICATO, Ermínia. Indústria da construção e política habitacional. Tese de doutorado apresentada na Faculdade de Arquitetura e Urbanismo da Universidade de São Paulo, São Paulo, 1984.

Cidade e Território no Brasil contemporâneo: neodesenvolvimentismo social ou crescimento predatório? In: XV Encontro Nacional da ANPUR, Desenvolvimento, Planejamento e Governança. ANPUR/RECIFE, 2013.

- Política urbana e de habitação social: um assunto importante pouco importante para o governo FHC. Revista Praga, São Paulo: Hucitec, v.1, n.6, p.67-78, 1998.

MARTINS, José de Souza. O cativeiro da terra. São Paulo: Ciências Humanas, 1983.

MATTOS, P.; LINCOLN, C. L.. A entrevista não estruturada como forma de conversação: razões e sugestões para sua análise. Rev. adm. pública; 39(4):823-847, jul-ago/2005. 
MESQUITA, Maria. COHAB: ontem, hoje e a lembrança. Fortaleza, 2000.

MOREIRA, Francisco Giovani Pimentel. O capital imobiliário e a produção urbana de Fortaleza: estudo de caso para o período de 1950-1970. Dissertação de mestrado apresentada ao Departamento de Ciências Sociais, Universidade Federal do Ceará. Fortaleza-CE, 2004.

MARTINS, J. de S. O cativeiro da terra. São Paulo, Ciências Humanas. 1983.

PÁDUA, Leandro Rodrigues. A produção habitacional do Programa Minha Casa Minha

Vida na Região Metropolitana de São Paulo. Dissertação de mestrado apresentada à Universidade de São Paulo. São Paulo, 2015.

PEQUENO, Luis Renato Bezerra (Org). Como anda Fortaleza. Rio de Janeiro: Letra Capital, 2009.

PEQUENO, Luis Renato Bezerra; FREITAS, Clarissa Sampaio. Produção habitacional na região metropolitana de Fortaleza: avanços e retrocessos. Rio de Janeiro: Anais do XIV Encontro Nacional da ANPUR, 2011.

PEQUeNO, Renato; VIEIRA, Rosa. O Programa Minha Casa Minha Vida na Região Metropolitana de Fortaleza-CE: análise dos arranjos institucionais. Cadernos Metrópole, Vol. $18, n^{\circ} 35,191,2016$.

PEQUENO, Renato; ELIAS, Denise. Reestruturação Econômica e a Nova Economia Política da Urbanização no Ceará. MERCATOR (Online), v. 12, p. 95-112. Fortaleza: 2014.

SHIMBO, Lúcia; RUFINO, Beatriz; AMORE,Caio. Minha Casa... e a cidade? Avaliação do Programa Minha Casa Minha Vida em seis estado brasileiros. (2015) In: P.136 VIEIRA E PEQUENO. Inserção Urbana e segregação espacial: análise do PMCMV em Fortaleza, cap. 6.

PEREIRA, A. Q.. Veraneio marítimo e expansão metropolitana no Ceará: Fortaleza em Aquiraz. Dissertação de mestrado apresentada ao Departamento de Geografia da Universidade Federal do Ceará. Fortaleza, 2006.

MÁXIMO, Rérisson. Moradia, arquitetura e cidade: mudanças e permanências na produção da habitação social no espaço urbano metropolitano de Fortaleza. Dissertação de mestrado apresentado ao Instituto de Arquitetura e Urbanismo da Universidade de São Paulo. São Carlos: 2012.

RIBEIRO, Luiz Cesar de Queiroz. Da propriedade fundiária ao Capital Incorporador: as formas de produção da moradia na cidade do Rio de Janeiro. Tese de Doutorado. FAU-USP. São Paulo, 1991.

Dos cortiços aos condomínios fechados: as formas de produção da moradia na cidade do Rio de Janeiro. Rio de Janeiro: Civilização Brasileira; IPPUR/UFRJ; FASE, 1997. RUFINO, M. Beatriz Cruz. Incorporação da metrópole: centralização do capital imobiliário e nova produção do espaço em Fortaleza. Tese de doutorado apresentada ao Programa de Pós- 
Graduação da Faculdade de Arquitetura e Urbanismo da Universidade de São Carlos. São Paulo, 2012.

SANTOS, Elizette de Oliveira. Propriedade privada da terra e expansão urbana: o caso da concentração fundiária na implantação de loteamentos em Fortaleza (1930-2000). Ateliê Geográfico (UFG) , v. 6, p. 61-87, 2012.

SHIMBO, Lúcia Z.. Habitação Social, Habitação de mercado: a confluência entre estado, empresas e capital financeiro. Tese de doutorado apresentada ao Programa de Pós-Graduação da Faculdade de Arquitetura e Urbanismo da Universidade de São Carlos, São Paulo, 2010.

SILVA, Ana Cristina Mota. A propriedade privada da terra e a produção de novas espacialidades na cidade de Fortaleza. Dissertação em Geografia. Faculdade de Filosofia Letras e Ciências Humanas da Universidade de São Paulo. São Paulo, 1999.

SOUZA, Maria Salete de. Análise da estrutura urbana. In: DANTAS, Eustógio Wanderley Correia; SILVA, José Borzacchielo da; e COSTA, Maria Clélia Lustosa. De cidade à metrópole: (trans)formações urbanas em Fortaleza. Fortaleza: Edições UFC, 2009, p.13-86.

TAVARES, R.. A estrutura de financiamento das empresas brasileiras abertas do setor de construção civil incorporadas de empreendimentos imobiliários: um estudo comparativo. Tese de doutorado apresentada à Faculdade de Economia, Administração e Contabilidade /Universidade de São Paulo. São Paulo, 2008.

TOPALOV, Christian. Les Promoteurs immobiliers: Contribution à lánalyse de la production capitaliste du longement em France. Paris: Editora Mouton, 1974. Fazer a história da pesquisa urbana: a experiência francesa desde 1965. In: Espaço \& Debates, Revista, n. 23. São Paulo: 1988. 